\title{
The Explorer
}

in English Fiction

Peter Knox-Shaw, M.A. (Cantab.)

A Dissertation submitted for the Ph.D. degree at the University of Cape Town, I985 
The copyright of this thesis vests in the author. No quotation from it or information derived from it is to be published without full acknowledgement of the source. The thesis is to be used for private study or noncommercial research purposes only.

Published by the University of Cape Town (UCT) in terms of the non-exclusive license granted to UCT by the author. 
CONTENTS

$\begin{array}{ll}\text { Preface } & \text { iii }\end{array}$

Abstract iv

I. The Explorer, and Views of Creation I

II. Crusoe, Desert Isle Ventriloquist 45

III. Defoe's wilderness: The image of Africa in Captain Singleton $\quad 70$

IV. Melville's Happy Valley: Typee and its

literary context 95

V. Captain Ahab and the Albatross: Moby Dick

in a period context I28

VI. Conrad Dismantles Providence: Deserted idylls in An Outcast of the Islands $\quad$ I56

VII. The Hidden Man: Heart of Darkness, its context $\begin{array}{ll}\text { and aftermath } & 187\end{array}$

VIII. The Country of the Mind: Exploration as metaphor in Voss 224

IX. The Sacramental wild: A Fringe of Leaves 250

Notes and References $\quad 272$

Bibliography 3I3

Index $\quad 330$ 


\section{Preface}

I should like to express my gratitude to Professor Haresnape who supervised this dissertation and supplied - even when pressed for time - encouragement, counsel and detailed advice. To the librarians and staff at Jagger Library, the South African Library, the British Museum, the Public Record Office, and the University Library of Cambridge my thanks are due for much patience and frequent help. My chief intellectual debts are acknowledged in the pages that follow.

Since a number of footnotes have run to some length I have collected all notes and references together at the end of the text. In this, as well as in other respects, I have aimed to comply with the guidelines laid down by the M.H.R.A. Style Book. 
Abstract

Although there bave been a number of critical works on the novel given over to topics such as adventure, colonization or the politics of the frontier, a comparative study of novels in which an encounter with unknown territory holds central importance has till now been lacking. My aim in this thesis is to analyse and relate a variety of texts which show representatives of a home culture in confrontation with terra incognita or unfamiliar peoples. There is, as it turns out, a strong family resemblance between the novels that fall into this category whether they belong, like Rohinson Crusoe, Coral Island or Lord of the Flies, to the "desert island" tradition where castaways have exploration thrust upon them or present, as in the case of Moby Dick, The Lost World or Voss, ventures deliberately undertaken. There are frequent indications, too, that many of the novelists in question are aware of working within a particular, subsidiary genre. This means, in sum, even when it comes to texts as culturally remote as, say, Captain Singleton and Heart of Darkness that there is firm ground for comparison. The emphasis of this study is, in consequence, historical as well as critical.

In order to show that many conventions which are recurrent in the fiction inhere in the actual business of coming to grips with the unknown, I begin with a theoretical introduction illustrated chiefly from the writings of explorers. Travelogues reveal how 
large a part projection plays in every rendering of unvisited places. So much is imported that one might hypothesize, for the sake of a model, a single locality returning a stream of widely divergent images over the lapse of years. In effect it is possible to demonstrate a shift of cultural assumptions by juxtaposing, for example, a passage that tricks out a primeval forest in all the iconography of Eden with one written three centuries later in which - from essentially the same scene - the author paints a picture of Malthusian struggle and survival of the fittest. And since the explorer is not only inclined to embody his image of the natural man in the people he meets beyond the frontiers of his own culture, but is likely also to read his own emancipation from the constraints of polity in terms of a return to an underlying nature, the concern with genesis is one that recurs with particular persistence in texts dealing with exploration. With varying degrees of awareness novelists have responded, ever since Defoe, to the idea that the encounter with the unfamiliar mirrors the identity of the explorer. Their presentations of terra incognita register the crucial phases of social history - the institution of mercantilism, the rise and fall of empire - but generally in relation to psychological and metaphysical questions of a perennial kind. The nature of man is a theme that proves, indeed, remarkably tenacious in these works, for a reason Lawrence notes in Kangaroo: "There is always something outside our universe. And it is always at the doors of the innermost, sentient soul". 
After the introductory chapter I proceed chronologically with the four novelists who have contributed most, in my view, to the genre - Defoe, Melville, Conrad, Patrick White. In each case I deal principally with two texts: Robinson Crusoe, Captain Singleton, Typee, Moby Dick; An Outcast of the Islands, Heart of Darkness; Voss and A Fringe of Leaves. Wealth of reference is often a mark of literary stature, and in following these books any attentive reader is led from Genesis to Aboriginal myths of creation, from Hobbes to Rousseau and Darwin. Major works have a way, too, of declaring their genetic traits. Allusions to Rasselas and The Ancient Mariner, for instance, spell out Melville's glorious debts to diverse traditions, while his hybrid forms record the impact of a scientific spirit that did much to transform travel writing. I draw on accounts by explorers throughout, not only where immediate sources are concerned (Woodes Rogers, Stanley, Leichhardt, etc.), but so as to trace the correspondence between the non-fictional and novelistic realms. And although my comments on them tend to be brief, novels about exploration by writers other than the principal four come in for discussion when pertinent to the issues at hand: so Verne and Haggard, for example, provide a perspective to Conrad's treatment of recidivism in Heart of Darkness, while Coetzee and Brink supply comparisons with Patrick White's handling of the return to polity in A Fringe of Leaves (I976), a text even more fully receptive than Voss to the culture it penetrates. 
The Explorer, and Views of Creation

Not far from what he took to be the site of Eden, Columbus turned back. A fierce tide at the Orinoco mouth decided him against sailing up-river to look for Paradise, and to judge from his account of the scene the dangers he faced were real enough:

And behind this current, there was another and another which all made a great roaring like that of the sea when it breaks and dashes against rooks ... This was continuous, night and day, so that I believed that it would not be possible to go against the current, or to go forward owing to the shallows.

And in the night, when it was already very late, being on the deck of the ship, I beard a very terrible roaring which came from the direction of the south towards the ship. And I stayed to watci, and I saw the sea from west to east rising, like a hill as high as the ship, and still it came towards me little by little. I

Columbus's reading of the situation was, however, far from simply a practical matter. What he saw from the deck of his ship proves to have been shaped by a mental image; and the instance is one among many in a venture which points, as a whole, to the force of the preconceived. The continent that rose out of the sea not only answered his dream of finding land far to the west but continued to be seen through it. So it was that America remained the eastern seaboard of Asia, and in consequence the region of Paradise also. Although a densely tangled skein of reference, 
ranging from the Apocryoha to Imago Mundi, coloured Columbus's view of the New Norld, the influences informing his particular impression of the Orinoco can be pin-pointed by soing no further afield than to two books which accompanied him on his voyages, the Bible and Mandeville's Travels. ${ }^{2}$ The Book of Genesis spoke of four rivers flowing out of Eden, the third of which moved eastward trrough Asia ( $2: I 4)$; and Mandeville who situated his paradys terrestre "towards the est at the begynnynge of the erthe", indeed so far east as to occupy the opposite side of the globe, drew his tall story to a close with a description of the torrents that barred its approach:

To man that is mortelle ne may not approchen to that Paradys ... be the ryueres may no man go, for the water renneth so rudely and so scharply because that it cometh doun so outrageously from the high places abouen that it renneth in so grete wawes that no schipp may not rowe ne seyle agenes it. And the water roreth so and maketh so huge noyse and so gret tempest that no man may here other in the schipp, though he cryede with alle the craft that he cowde in the hieste voys that he myghte. Nany grete lordes han assayed with gret wille many tymes for to passen be tho ryueres toward Paradys with fulle grete companyes, but thei myght not speden in hire viage ... So that no mortelle man may approche to that place withouten specyalle grace of God. ${ }^{3}$

That it was in tre thrall of this passage that Columbus watched the racing waters at the river mouth is clear not only from the way he echoes Nandeville's conclusions, but lingeringly returns 
to the saving clause, "withouten specyalle grace of God":

\begin{abstract}
Not that I believe that to the summit of the extreme point is navigable, or water, or that it is possible to ascend there, for I believe that the earthly paradise is there and to it, save by the will of God, no man can come. 4
\end{abstract}

Columbus who had in earlier days regarded himself as the great voyager prophesied by Isaiah, ${ }^{5}$ conveys an impression of self-doubt when, in a further passage on the confluence, he presents the currents as responding to the patterm of a familiar moral conflict, the besiegement of innocence by vice:

Then I surmised, concerning the streaks of current and the rolling waves, which went out of and entered into these straits, with that great and violent roaring, that there was a battle between the fresi water and the salt. The fresh struggled with the other to prevent its entrance, and the salt with the other that it might not come out ... the fresh water was always victorious. 6

Whatever the strength of the tides Columbus's assessment of his chances on the estuary evidently depended also on other less physical considerations - partly on an item of topographical lore, partly on a reckoning of his state of grace. Various aspects of his cultural life were focussed in the immediate scene, and so brought to bear upon his judgement. 
For the critic who studies novels about exploration travelogues have a value quite apart firom any importance they might have as sources, in that they show how themes which are basic to the fiction (and subject to the usual trafficking of literary influence) belong in the first place to the actual business of coming to grips with the unknown. In this respect Columbus's account of the Orinoco mouth is particularly instructive for it points to two features - more specifically to a process and a concern - which recur in travel writing and hold a central place, moreover, in novels about exploration. The process is projection: a mental image is transferred to an object outside the self - for our purposes most commonly to a phjsical setting. The concern is with genesis: the unfamiliar setting returns the image of an original state, or is seen as charged in some way with the evidences of creation. It is with this last issue, which obviously presents a special case of the first, that I shall chiefly be dealing. Just how decisive a part it plays in the fiction I hope to show, but my aim in this chapter is to look at the ways in which explorers have written about the immanence of the primeval; and while I shall do my best to trace the main developments in the history of this concern I can hardly fail to indicate its remarkable persistence.

To generations of voyagers in the wake of Columbus the New Norld gave substance to a vanished, legendary past, but long after faith in Genesis had faded, explorers continued to view distant places in the light of some belief as to how life began. Specific economic or 
political motives play their part in these views as we shall see, but no single reading of this kind seems adequate to explain the variety of primordial states in question; and here I shail try to account for the prevalence of this concern by considering whether there may not be an intrinsic as well as functional relationship between it and projection, a process at work in every rendering of the unknown. In any case it is to this last topic that we need first to turn.

To project, in the sense we shall be using it, is to locate a mental image in the external world. An obvious feature of this process is that an inward tendency presents itself as - and sometimes gets mistaken for - an objective reality. Although the idea goes back a long way the word came into currency only in the nineteenth century, and it is appropriate that Coleridge who so insistently questioned the limits of subjective vision should have been the first to use it. The figurative sense he introduced seems to have owed its force less to the original Latin root (meaning to throw forward) than to an already standard usage in optics. When Emerson, for example, speaks of the hero-worshipper as one who

intoxicated with his admiration of a hero, fails to see that it is only a projection of his own soul which he admires

he carries over the sense of the special scientific term:

with a Prism you strike the Rainbow-colours upon a wall, and observe where red is projected.? 
Even where the word itself has not been at issue, the idea of projected light has frequently served to illustrate the influence of a mental disposition. So Proust finds an emblem for the shaping work of the imagination when he decribes how a magic lantern flooded the familiar outlines of his childhood bedroom with scenes from a romantic tale. 8 But al though the optical metaphor provides a striking model of the mind's power to impose it proves in other respects inadequate, or even misleading. When it comes, for instance, to accounting for the ways in which images attach therselves to objects, the metaphor selects from a wide range of possible transformations only that extrene typified by the hallucinatory. For the external world, in so far as it enters the optical analogy at all, does so as a blank screen or incidental backdrop, devoid of the capacity either to suggest or control. Yet if we turn to a representative case of projection, the famous passage in which Columbus portrays the island he had named La Espanola as an earthly paradise, we find among a few details that he may have conjured out of the air others that suggest the recalcitrant identity of the setting, and much else that falls into a middle realm to which a forgotten sense of projection, denoting alchemical change, would do more justice than the optical term. The paragraph is from his opening description of the New World:

This island and all the others are very fertile to a limitless degree, and this island is extremely so. In it there are many harbours on the coast of the sea, 
beyond comparison with others which I know in Christendom, and many rivers, good and large, which is marvellous. Its lands are high, and there are in it very many sierras and very lofty mountains, beyond comparison with the island of Teneriffe. All are most beautiful, of a thousand shapes, and all are accessible and filled with trees of a thousand kinds and tall, and they seem to touch the sky. And I am told that they never lose their foliage, as I can understand, for I saw them as green and as lovely as they are in Spain in May, and some of them were flowering, some bearing fruit, and some in another stage, according to their nature. And the nightingale was singing, and other birds of a thousand kinds in the month of November there where I went. There are six or eight kinds of paln, which are a wonder to behold on account of their beautiful variety, but so are the other trees and fruits and plants. In it are marvellous pine groves, and there are very large tracts of cultivable lands, and there is honey, and there are birds of many kinds and fruits in great diversity. In the interiors are mines of metals, and the population is without number. 9

Columbus already looks with the appraising eye of the colonist as his bracketing of mines and people in the last sentence shows, but this does not prevent him from reljing on traditions of a more sacred character. The landscape he presents, while remaining particular and distinct, is always at the point of coalescing into a Renaissance image of Paradise. Just as tall trees "seem to touch the sky" so the scene as a whole is referred to the imaginative 
properties of Eden, chief of which here are invariance and plenitude. Rather than describe a perpetual spring Columbus relates what he sees to the notional image of a climate unspoilt by the fall. So he finds the leaves of early winter as fresh as those of Europe in May, points at trees in varying stages of their season, and yet allows that it is only through hearsay that he supposes the woods never bare. So long as his eyes are on the scene the things be describes enjoy a fair measure of independence. The climate and evergreen forests of the Caribbean were of a kind, of course, to feed his expectations. Only when he brings in the November song of the nightingale, a bird absent from Europe over the winter, does he make the principle of invariance fully explicit; and at the cost, then, of some infidelity to the setting, for there never have been nightingales in America. It is not uncommon for explorers to lump unknown creatures into familiar categories; and were it not for the resonance of this detail and its dramatic placing (almost comparable to Milton's telling use of the bird in his account of twilight in Eden) ${ }^{\text {IO }}$ Columbus might be assumed to have grown tired of ostensive definition - the process responsible for his odd phrase, "there where I went" - and fallen back on an approrimate label. It seems more likely, however, that the nightingale was the result of a metamorphosis managed by his ears.

Certainly the other organizing principle of the passage, the ideal of plenitude, gives away its a priori character much sooner, 
indeed from the very first sentence. For here Columbus introduces the word "limitless" into a context that fails to support its meaning - he speaks of all the islands being "fertile to a limitless degree and this island extremely so". The idea continues, all the same, to inspire his syntax. Trains of co-ordinated clauses underline his impression of immeasurable abundance ("there are ... and there are ... and there are ..." eto.), and the effect is heightened still further by his marking off of "some" against "all", and by his related noting of single or easily counted items against a blurred backdrop of "a thousand" or "very many". Whether it was the Book of Genesis with its insistence on the variety of creation ("every tree", "every beast", "every fowl"), or the radiant pictorial detail of some Quattrocento treatment of the subject that lay at the back of Columbus's mind it is impossible to tell, but the presence of Eden makes itself deeply felt, and seems, moreover, to have sharpened rather than dulled attention to the setting. It is entirely consistent that Columbus should rish to distinguish eight species of palm, or elsewhere supply the first European account of the yellow-wood, which he describes as a pine with berries like the olive. Yet the blend of observation and received ideas that characterizes his writing is not, after all, far from that found in the updateci medieval maps which survived into his period. II The world is shaped on these as a perfect trefoil or, since it seemed reasonable that the Orbis Terrarum should emblazon its own inftials, in the form of a $T$ within an 0 . Jerusalem - in view 
of the text, "I have set her in the midst of nations"' - invariably atood at the centre. It vas against this ground that details from the portolan charts and early voyagers were, as far as possible, fitted. A aimilar uniformity of design underlines Columbus's reports of terra nuova.

Travelogues sbow how basic projection is to any reading of the unknown. However evocative the features of a newly observed setting prove they are likely, at most, to play only a limited part in the development of an overall impression. For while they may challenge, as well as confirm, they cannot significantly contribute to those habits and beilefs that make up the disposition of the observer. It is easy to supcose that Columbus would have failed to find a paradise had he been confronted with a less amenable coast outside the tropics; but, in fact, throughout the following century, in landfalls made along the entire seaboard of the continent, the same pattern of response recurs. Writing of the place that would be named Virginia, Arthur Barlowe comments on how the natives live "after the maner of the golden age", and goes on to spell out the notion that sustains his rapturous and often minute descriptions: "the earth bringeth foorth all things in aboundance, as in the first creation". "Despite the northerly latitudes a similar understanding runs through the account of Newfoundland by Edward Haie who breaks off a long list of animals with the remark - "we could not observe the bundreth part of creatures in those unhabited landss but these mentioned may 
induce us to glorifie the magnificent God, who hath superabundantly replenished the earth". I3 Writing in the next century of country between these two regions (the Plymouth district, on which earlier explorers spent many a superlative) ${ }^{\text {I4 }}$ the Pilgrim Fathers, on the other hand, present an altogether different picture. Ironically enough it is often the observation of abundance that supports their sense of the land as a menacing waste. In this as well as in other respects, the following passage from the retrospect of a Puritan spokesman is typical:
what could they see but a hideous and desolate wildermess, full of wild beasts and wild men - and what multitudes there might be of them they knew not ... For summer being done, all things stand upon them with a weatherbeaten face, and the whole country, full of woods and thickets, represented a wild and savage hue. If they looked behind them, there was the mighty ocean which they had passed and was now as a main bar and gulf to separate them from ali the civil parts of the world. I5

Of course the Pilgrim Fathers came not as discoverers but as exiles, without the hope - as the last sentence makes clear - of any return. Equally to the purpose, however, they came equipped with the identity of Israelites who had exchanged captivity for the pains and trials of the Wilderness. Exodus rather than Genesis presided over their encounter with the interior. Their outlook was sustained, moreover, by a Calvinist repugnance towards the natural state. Whereas to the more orthodox it seemed that the seeds of Eden (Gen.I:II-I2) had carried the vestiges of perfection into a fallen world, the 
American Puritans inclined to the view that original sin had obliterated all trace of the divine image in man. Differences of a profound theological cast underlay the changing faces of the New World.

From the standpoint of Richard Hakluyt, the great Elizabethan anthologist of voyagers, it is the individual difference between his explorers that calls for comment. He hits on a vivid metaphor to describe the way "the desires of divers men" mould impressions of the New World. "If an oxe bee put into a medowe", he writes, "hee will seeke to fill his bellie with grasse, if a Storke bee cast in shee will seeke for Snaices, if you turne in a Hound he will seeke to start an Hare: So sundry men entring into these discoveries propose unto themselves severall endes". I6 The work of projection is thrown into relief by comparison, but Hakluyt's meadow - the paradigmatic case of a single object drawing a whole spectrum of response - belongs less to the historian than to the creative writer, Shakespeare offers just such an exposition in The Tempest where each character creates, in effect, an island in his own image - a oircurstance made conspicuous by the rather special treatment of the setting. It is, of course, common practice in Renaissance drama for characters to report repeateily on what they see but they do not, as a rule, disagree about what there is to be seen. In The Tempest, however, the island takes on as broad a range of aspects as there are characters, and it goes through all the fluctuations of a chameleon when the characters clash their differing 
points of view. In the following extract, for example, while the level-headed Adrian asserts a nature unpolisied but not intemperate, and the well-meaning Gonzalo transmits a golden age, Antonio and Sebastian, about to plot the death of Alonso, chip in jointly with their jaundiced asides, producing between them an image that strongly suggests the predatory:

Adr. The air breathes upon us here most sweetly.

Seb. As if it had lungs, and rotten ones.

Ant. Or as 'twere perfun'd by a fen.

Gon. Here is everything advantageous to life.

Ant. True; save means to live.

Seb. Of that there's none, or little.

Gon. Hoil lush and lusty the grass looks! how green!

Ant. The ground, indeed, is tarny.

Seb. With an eye of green in't. I7

The tawny beast with the green eye is planted in the landscape by the conspirators who, when they are later caught with their swords drawn, summon further wild creatures of their making. For while Gonzalo and Alonso wake, respectively, to music and to silence Antonio and Sebastian explain their aggressive stance by peopling the island with a "herd" of roaring lions.

What the characters in The Tempest project onto their seiting they also project on each other, but the setting which keeps its mystery intact (owing partly to the effaced omniscience of the dramatic presentation) returns the clearer if less complicated image. The desert island serves Shakespeare as a mirror which he 
holds up to the nature of his characters, and the play reminds us of the way distant places reflect the traits and beliefs of those who observe them. It alerts us to the fact that while projection colours every facet of experience it declares itself most forcibly where the unfamiliar is concerned. The less familiar the setting the more highly burnished the surface presented to the observer. There are a number of reasons why this should be so. Conrad pointed to one when he likened Europeans in a tropical environment to "blind men in a large room". I8 The unknown resists assimilation, and accordingly leaves a wide margin for the imaginary. Without invoking Whorf one can recognize that the absence of an appropriate nomenclature blunts perception, and there are, besides, a variety of psychological influences that curb attention to experience that is out of the way. The well-attested case of the Eskimo tribe who decided, after their encounter with some Russian explorers, that they had beon visited by a party of squid, ${ }^{I 9}$ points to a further corollary. When the unknown cannot be ignored there is a tendency to approximate it, at any cost, to the familiar.

Analysis along these lines confirms the idea that terra incosnita acts as a mirror to the habitual. But allowance must also be made for the imaginative stimulus imparted to explorers by unvisited places, a stimulus often sufficiently strong, it proves, to arouse deep-seated feeling, and to stir public assumptions that ordinarily go unstated. For all these reasons the travelogue can be put to work as an instrument exceptionally sensitive to historical change. In place of the model supplied by The Tenpest we have only to think 
of a single place giving rise to a succession of widely divergent Images over the lapse of years. In the comparison that follows more than three centuries separate the accounts of what remains essentially the same setting. For al though the scene viewed in I562 by the French explorer Ribault was situated on the coast of Florida, and that viewed by Stanley in I887 at the heart of the Congo, the particular landscape described by either explorer could as well have supported the conclusions drawn by the other. A setting, effectively constant, indexes in this case a crucial shift in the understanding of creation.

Translated from the French by Hakluyt and included in his first volume, Divers Voyages Touching the Discovery of America (I582), Ribault's narrative includes one of the many passages, ${ }^{20}$ broadcast through the literature of travel in the late sixteenth century, which show the New World in the image of the golden age:

We entred and viewed the countrie thereaboutes, which is the fairest, fruitfullest, and pleasantest of al the world, abounding in hony, venison, wilde foule, forests, woods of all sortes, Palme trees, Cypresse and Cedars, Bayes $y^{\ominus}$ highest and greatest, with also the fayrest vines in all the world, with grapes according, which without natural art and without mans helpe or trimming will grow to toppes of okes and other trees that be of a wonderfull greatnesse and height. And the sight of the faire medowes is a pleasure not able to be expressed with tongue: full of Hernes, Curlues, Bitters, Mellards, Egrepths, woodcocks and all other kinde of small birds: with Harts, Hindes, Buckes, wilde Swine, and all other kindes of wilde beastes, as we perceiued well, both by their 
footing there, and also afterwardes in other places, by their crie and roaring in the night.

Also, there be Conies and Hares: Silke wormes in merueilous number, a great deale fairer and better then be our silk wormes. To bee short, it is a thing vnspeakable to consider the thinges that bee seene there, and shalbe founde more and more in this incomperable lande, which neuer yet broken with plough yrons, bringeth forth al things according to his first nature, wherewith the eternall God indued it. ${ }^{2 I}$

Where Columbus set out to quantify the illimitable Ribault attempts to utter the inexpressible. Twice he insists that the scene oannot be encompassed by words, and in view of the superiority he ascribes to nature's products over those of art (wild vines supply the fairest grapes), his claim seems to relate to a belief that the orfinal state of nature - which it is his privilege to view - offers a perfection beyond that of the arts, the redemptive institutions available to fallen man. This is the idea which informs Montaigne's famous essay "Of the Caniballes", published two decades later, in which it is argued that the natural state exceeds "all the pictures wherewith licentious Poesie hath proudly imbellished the golden age"; and that language itself is tainted by human corruption "The very words that import lying, falshood, treason, dissimulations, covetousnes, envie, detraction, and pardon, were never heard of amongst [the savages]". 22 of course, when Montaigne pronounces that the original state was without nomos, or what he calls "human combination" - "no intelligence of numbers, no name of magistrate, 
nor of politike superiority ... no contracts, no successions, no partitions" etc. - he departs from Christian orthodoxy. Eden was tilled by Adam. 23 Ovid, however, in his account of the golden age had supplied the model of an existence, free of codes and laws, over which a benevolent, self-cultivating nature presided. Whereas Columbus points to land that can be cultivated, Ribault follows the Metamorphoses ("the earth 1tself, without compulsion, untouched by the hoe, unfurrowed by any share, produced all things spontaneousl $\left.y^{\prime \prime}\right)^{24}$ in celebrating nature's sufficiency - "this incomperable lande, which neuer yet broken with plough yrons, bringeth forth al things according to his first nature"; and the same emphasis pervades his description of the vigorous creepers: "the fayrest vines in all the world, with grapes according, which without natural art and without mans helpe or trimming will grow to toppes of Okes and other trees that be of a wonderfull greatnesse and height". On this last detail the poet Drayton clearly drew for his lines addressed to Hakluyt, entitled "To the Virginian Voyage", and it is amusing to observe that he restores the full Ovidian context that underlay Ribault's impression, introducing the "golden age" itself, zephyrs and otium:

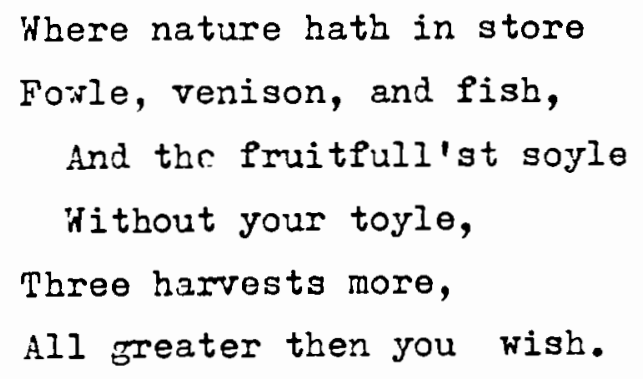


And the ambitious vine

Crownes with his purple masse

The Cedar reaching hie

To kisse the sky,

The Cypresse, pine

And uge-full Sassafras.

To whose, the golden age

Still natures lawes doth give...25

Writing with further information at his disposal Drayton was able to identify Ribault's bay tree as the sassefras - a name for the American laurel of probable Spanish-Indian derivation. Ribault's taxonomy is by contrast unrelievedly European; and Hakluyt takes the French explorer's process of approximating the unknown to the familiar a step further when he glosses the egrets - a species indigenous to France but not to England - as "beautiful birds, like herons, but white". Unlike Adam who himself gave the names to the beasts and birds of Eden, Ribault is equipped only with an imperfect index to the myriad forms of creation; and language, even if not exactly in the ways he expected, does betray his perceptions. The clause that leads into the passage quoted supplies an instance. Here Ribault in describing his encounter with the inhabitants of the region evokes an aura of natural fellowship, but his vocabulary imposes a structure of foudal relation on the tribesmen, further reinforced by the nature of his gifts:

After we had a good while louingly entertained and presented them with like gifts of habersher wares, cutting hookes and 
batchets, and clothed the king and bis brethren with like robes, as we had given to them on the other side: we entred and viewed the country.

The easy parataxis of the ensuing list of creatures - which seems to assume Isaiah's prophecy of the lion lying down with the lamb, and certainly dispels any notion of subjugation and mastery - is bardly in keeping with his conversion of the Indian headsman into a robed aristocracy. But as is the case with Shakespeare's Gonzalo, steeped in Montaigne -

Gon.

contract, succession

Bourn, bound of land, tilth, vinejard, none;

No use of metal, corn, or wine, or oil;

No occupation; all men idle, all;

And women too, but innocent and pure:

No sovereignty; -

$\underline{\text { Seb. }}$

Yet he would be King on't 26 -

the latter end of Ribault's commonwealth forgets its beginning.

Midway through In Darkest Africa (I890) Stanley devotes a chapter to "The Great Central African Forest" in which he repeatedly impresses on his readers that he is dealing with a primeval setting, with "that old growth untouched by man, and left since the earliest time to thrive and die". 27 Self-sufficient and self-generated, the scene expresses the absence of man rather than the presence of God. The sole creator here is the perceiver - a sense conveyed by Stanley's adoption of a descriptive mode which proceeds by fiat: 
Then from tree to tree run cables from two inches to fifteen inches in diameter... fold them round the trees in great tight coils ... let slender cords hang down also in tassles ... Work others through and through ... Now cover ... with a thick moss. 28

The recipe format is kept up for paragraphs at a time but in context the effect is far from quaint. Stanley is among the most articulate of explorers and his descriptive passages which never fail to be graphic, are interspersed with commentaries that are apt as well as lavish. Towards his pivotal statement that "the forest is typical of the life of humanity" he moves with poise, fully aware of the animation which he has already imported into his account of the setting. His prose pullulates. In the course of a single sentence he introduces "a mushroom staring out of a fern", "fungi clinging like barnacles to a deeply-wrinkled log", "the grey green face of en elephant-eared plant", "tumorous lumps" and "tears of gum". The sentence finally winds to its close in vivid mimicry of the creepers (an endless source of fascination), instinct as ever with rapacious life:

[the eye caught] length after length of whiplike calamus squirming and twisting lianes, and great serpent-like convolvuli, winding in and out by mazy galleries of dark shadows, and emerging triumphant far above to lean their weight on branches, running coils at one place, forming loops at another place, and then stretching loosely their interminable lengths out of sight. ${ }^{29}$ 
In contrast to Ribault, Stanley pictures his scene in movement, typically in movement that recapitulates growth; and while he presents natural forms in terms of their function, his unsteady zoological metaphors - his objects are always at the point of turning into something else - challenge the fixity of their labels. There is, of course, no paradox in his projection of a full biological spectrum onto the vegetable world in order to establish an equivalence for human life. He is concerned with an evolutionary conception of man as a being continuous with lower forms of creation, and comparably engaged in a struggle for survival. From the lianes whose triumph is manifest in the firn support they have found at the top, Stanley now switches to a scene from the civilized world and pursues his analogy further:

[The forest] has suggested a morning when I went to see the human tide flowing into the City over London Bridge between half-past seven and half-past eight, where $I$ saw the pale, overworked, dwarfed, stoop-shouldered, on their way to their dismal struggle for existence. They were represented here faithfully, in all their youth, vigour, and decrepitude; one is prematurely aged and blanched, another is goitrous, another is organically weak, another is a hunchback, another suffers from poor nutrition, many are pallid from want of air and sunshine, many are supported by their neighbours because of constitutional infirmity, many of them are toppling one over another, as though they were the incurables of a hospital, and you wonder how they exist at all. Some are already dead, and lie buried under heaps of leaves, or are nurseries of bush families and parasites, or are colonised by hordes of 
destructive insects; some are bleached white by the paralysing thunderbolt, or shivered by the levin brand, or quite decapitated; or some old veteran, centuries old, which was born before ever a Christian sailed south of the Equator, is decaying in core and vitals; but the majority have the assurance of insolent youth, with all its grace and elegance of form, the mighty strength of prime life, and the tranquil and silent pride of hoary old aristocrats; and you gather from a view of the whole one indisputable fact - that they are resolved to struggle for existence as long as they may. We see all characters of humanity here, except the martyr and suicide. For sacrifice is not within tree nature, and it may be that they only heard two precepts, "Obedience is better than sacrifice," and "Live and multiply." 30

Onto the forest Stanley projects a version of the social Darsinism popular in his day, a notional system to which economic individualism contributed perhaps as much as Darwin's biological theory. The co-operative aspects of survival, whether symbiotic or intra-organic though certainly underdeveloped in the evolutionary sciences themselves at this period - hardly enter into Stanley's ruthless portrayal of competitive strife. In so far as he finds anything in the forest to correspond to ameliorative institution, it is in the least dignified features of the scene - a hospital translates into a huddle of stunted trees. Indeed the primeval setting supplies Stanley with the means of separating "ought" from "is" for through it he spelis out the codes of a particularly abrasive natural law, before which the martyr stands condemed with the suicide. Through hig process of projection Stanley calls the status of ethics into doubt; and perhaps he ventured into deeper water than he knew, for while he 
23.

pretends to be divided in his loyalties he seems to have little more than lip service to offer the official god. Just as the older parts of the forest survive from an era before Christians ventured South, so the precepts which govern forest lore, he notes, antedate the coming of Christ. In conjunction with the command from Genesis - "Be fruitful, and multiply", 3I the words of Samuel "To obey is better than sacrifice", through which Jehovah admonished his people for sparing the Amalekites, ${ }^{32}$ not only conjure up a nature red in tooth and claw, but fairly exactly frame the Malthusian concept of expansion controlled by constraint. Again, in the paragraph that immediately follows, the old proverb "the devil takes the hindmost", prefixed by a version of "self do, self have", takes on the force of an evolutionary credo:

And as there is nothing so ugly and distasteful to me as the mob of a Derby day, so there is nothing so ugly in forest nature as when I an reminded of it by the visible selfish rush towards the sky in a clearing, after it has been abandoned a few years. Hark! the bell strikes, the race is about to begin. I seem to hear the uproar of the rush, the fieroe, heartless jostling and trampling, the cry, "Self for self, the devil take the weakest!" To see the white-hot excitement, the noisy fume and flutter, the curious inequalities of vigour, and the shameless disregard for order and decency! 33

Stanley begins by upholding the pieties, but his show of dismay even here - is uneasily balanced between moral deprecation and distaste for the mob. He is given away by the note of irrepressible 
jubilance on which his commentary ends, and the same exhileration at energies released, and recoil from the weak, underlies his. earlier inventory of types. ${ }^{34}$ From Stanley the primeval forest elioited a primitivism that was to become widespread, and more openly avowed, as the century moved to its close.

The accounts of Ribault and Stanley illustrate a pattern that proves general to the travelogues of explorers. A setting which is taken as primeval reflects a set of conceptions which derive from the explorer's understanding of genesis. The ramifications of the myth in question are not only far-reaching philosophically but often palpable in their consequences: they invade human relations and their imnediate effects can sometimes be traced. Such is the case with the sequel to Ribault's voyage to Florida. Recalled to France, Ribault left behind hin, under the care of his friend Captain Albert, a small band of men who pledged themselves to a utopian constitution outlawing all forms of servitude; but, falling on hard times, these colonists soon reneged on their principles, and when Captain Albert tried to oppose their enslavement of a local Indian tribe, he was hounded through the countryside and put to death. 35 It seems that the image of the golden afge seldom survived the experience of settlement. When it came to the point, intimations of paradise failed to restrain even Columbus from capturing hundreds of Indians for the slave markets of Seville. ${ }^{36}$ over the centuries the 
image of virgin territory was itself increasingly prostituted, the golden ag: cynically transposed into terms of hard cash. Urging basty exploitation, Sir Walter Raleigh, for example, writes:
Guiana is a countrey that hath yet her maydenhead, never sackt, turned, nor wrought ... the graves have not bene opened for golde, the mines not broken with sledges, nor their Images puld downe out of their temples. 37

Although the Ovidian emblem of an earth unbroken by ploughshares still persists, its ironic presence passes without acknowledgement. It was not only greed, however, that corroded the image of Eden. The very concept of colonial settlement implied a nature wanting redemption and control.

For Stanley as much as for Raleigh there was, at any rate, little risk of hypocrisy. The drama that Stanley observed among the leaves required no aesthetic frame. In his diary at least, first published in I96I, be was ready to apply the same scheme directly to experience, as in this description of his escape from a fired village:

There were at least 600,000 human beings struggling in a solid body in the same direction, trampling down the weak, aged and sick in their devouring baste to be away from the sea of fire below. It was a grand scene but a cruel one - for hundreds of sick, little ones and witless men and women perished in it. The flames almost took my breath away, they seemed to lick the air before it entered my lungs, but with heads bent low we charged on blindly, knowing no guide save self interest and self preservation. 38 
26.

Stanley's sense of the sublime is aroused on this occasion by the unmasking of blatant natural impulse. He finds the cruel scene grand because it shows up what he takes to be an underlying truth about human behaviour.

The advent of evolutionary theory was to sharpen, if only fitfully, the distinotion between "ought" and "is", and over the course of years to encourage the view that moral codes were created rather than discovered. To the modern reader familiar with Nietzsche's distinction between the Apollonic and Dionysian, or with George Moore's naturalistic fallacy, the obvious contrast between Ribault's and Stanley's accounts might seem to boil down to the difference between a prescriptive and descriptive undertaking. Yet, while it is true that Stanley is partly prompted by a scientific theory and that his view does justice to the force of instinct and the ferocity of strife, it is equally clear that his description is selective - so much so that even a feature as conspicuous as the flowering of the forest trees would represent (since energy is spent without individual gain) "sacrifice" rather than "selfishness" in the terms of his own metaphor. On the other hand, while it is trus that Ribault sustains his vision of a preordained order by drawing a veil across many aspects of the setting, and true moreover linat legend and dogma rather than observation inforra his sense of it, he clearly believes that it is from the scene itself that he reads the precepts of his creator. In short, while Ribault writes an idyll and Stanley a tendentious report neither shows himself at all ready to recognize any element 
of prescription. But, of course, the tendency is general. The notion that ethics is a prescriptive undertaking invariably resists acceptance. The unseen solicits proof, and - where martyrs are lacking - to found a system of values in nature is to supply some kind of sanotion. In this context a nature untouched by man or existing beyond the realms of polity - and whether seen thus as most wild or least unfallen - carries particular potency. For, as every variety of primitivism shors, the extraneous confers a special status, and accordingly provides a distinctive means of designating the essential. To jungles, to deserts, to the unvisited places of the world, men have turned over the centuries. One of their less official aims there has been to embody the image of their creation so as to see what they themselves are like under the coverings of civility. Some have regarded their home culture as a cormupt crust; some as a veneer of manners; the deeply redemptive role of social institution has been recognized by others. But every doctrinal system, whatever its drift, requires anchorage.

"The remotest parts of the world are the richest": 39 Herodotus meant his remark to be taken literally, but the staling effects of familiarity make its application universal. Explorers and for that matter their readers (for, as Mandeville with a canny eye on his public noted, "newe thinges and new tydynges ben plesant to here") 40 have always been enticed by novelty. Is it perhaps because the desire for freshness finds a supreme satisfaction in the fdea of a pristine world that explorers have so frequently preoccupied themselves 
with the evidences of genesis in distant lands? A simple process of transference is sufficient to zccount for the elision from things newly-observed to things as-if-newly-created: to see freshly is to confer freshness on what is seen. But this notion is perhaps more easily conceded in principle than in practice, and the concern with genesis requires, in any case, further fllustration.

Explorers are as diverse in professional type as the regions they explore. But the concern with genesis al though seldom, if ever, given a role as focal as that it consistently plays in the fictional genre, nevertheless crops up repeatedly in travelogues, regardless of the outlook and circumstances of the explorer. Again and again in the face of settings altogether opposed in character, the same imaginative directions are taken. The image of an original state is as readily furmished by a polar landscape as by a tropical jungle. Moonlight in the Antarctic opens for Edward Wilson a vista into a remote, and pre-evolutionary past:

The stillness was almost uncanny, one could imagine oneself on a dead planet, - that we were standing, not on the earth, but on the moon's surface; everything was so still and cold and dead and unearthly, with an absolute silence which one felt as broken by nothing but wild Nature's storms since the beginning of the world. $4 I$

For Burchell, writing a century earlier, the reward of travelling in southern Africa, through "country still in a state of nature", is his access to "the works of creation, ever delightful to all but those of 
a corrupt and depraved mind". 42 Likewise for Le Vaillant, writing of the same region on the eve of the French Revolution, the hinterland represents the natural state, and accordingly holds all the allure of original innocence.

Although his understanding of the process of projection is far from complete, Le Vaillant is among those explorers who are aware of an equivalence between the outer scene and inner life. Poised on the outskirts of settlement, Le Vaillant converts the physical frontier into a psychological one when he writes,

From this place the last post belonging to the Company was not far distant, and we arrived at it after a quick march of three hours. I was now about to withdraw myself from the dominion of man, and to approach a little towards his original conditicn. 43

What he means by this personal recovery of the "original condition" becomes clear when he reflects on the sensations of fre日dom that attend his departure from the beaten track:

Proud of his origin, man thinks it an indignity that people should beforehand dare to number his steps. I ... never thought myself completely froe, but when surrounded by the rocks, forests, and desarts of Africa... By the freedom of my will, which commanded them with sovereign sway, and by my complete independence, I really perceived in man the monarch of all arimater beings, the absolute despot of nature... [these] are only the pure and natural sentiments of liberty, which rejects, without distinction, every thing that seems desirous of prescribing its bounds. 44

Autonomy and freedom are equated here, and to further reflections in 
this vein (arising out of his relationship with a pet baboon) Le Vaillant adds that never before had he experienced the "full value of existence". $45 \mathrm{He}$ is ready, however, to suspend an earlier resolve to refuse invitations and avoid all unnecessary contact when be meets the Gonaqua, since they exemplify for him "the state of nature", a phrase often repeated in this connection. The comparison he proceeds to draw between these tribesmen and the Hottentots of the colony "who bear no marks of their ancient origin but an empty name; and who enjoy, only at the expense of their liberty, a little peace, purchased at a dear rate" 46 - is a revealing one for it re-echoes the terms in which he describes his own emancipation from the constraints of polity. What in essence he does is to project his own highly individualistic understanding of liberty onto the collective existence of the Gonaqua, whom he presents not only as a "free and brave people, valuing nothing but independence", but as incapable of "obeying any impulse foreign to nature". 47 Le Vaillant follows Rousseau when he affirms that "in an uncivilized state man is naturally good"; 48 but his notion of primitive society as a corporation of autocrats is informed by his own nevfound sensations of absolute despotism. In common with many explorers before and since, Le Vaillant superimposes his own freedom from social restriction on the poople he observes. Typically, again, he equates life beyond the realm of his own civilization with the natural, and consequently assumes that to be beyond polity is to be without it. In effectively turning a blind eye to the culture of the various tribes he encountered, to languages, laws and religions the details rather than the implications of which he was sometimes 
ready to ponder - Le Vaillant contributed to a pernizious error that anthropological awareness would later only gradually dispel. His intentions were benevolent, his view of the original state sustained by a strong French tradition of radical deism; but that linkage of the exotic with the natural, to which he among many others subscribed, was to prove unfortunate when less beneficent views of nature prevailed.

Canoeing dow the Orinoco River more than three centuries after Columbus had approached its mouth, Alexander von Humboldt - whom Darwin was to describe as the greatest of travellers, and whose comrents on the earlier literature of exploration are invariably shrewd - pointedly noted the absence of Eden: 49

We enjoyed the repetition of the same spectacle at several different points, and I may add, always with new delight. There cane down together, to drink, to bathe, or to fish, groups consisting of the most different classes of animals, the larger mammalia, being associated with manj coloured herons, palamedeas, and proudly-stepping curassow and cashew birds (Crax Alector and C. Pauri). "Es como en al Paraiso;" it is here as in Paradise, said, with a pious air, our steersman, an old Indian who had been brought up in the house of an ecclesiastic. The peace of the golden age was, however, far from prevailing among the animals of this American paradise, which carefully watched and avoided each other. The Capybara, a Cavy three or four feet long, (a magnified repetition of the Brazilian Cavy, Cavia aguti), is devoured in the river by the crocodiles, and on shore by the tiger. 50 
Humboldt never attempted a theory of evolution, but in common with many of Darwin's precursors he keeps a sherp eye both on biological variation and processes of change. In his idiosyncratic travel-book, Aspects of Nature (I808), he often speculates on prehistory, reconstructing lost landscapes, those "storied cemeteries of perished organic forms", and reviving gigantic creatures long buried in earth's "indurating crust". 5I That he was aware of projection is clear from his story about the pious Indian from the passage above, and in his late encyclopaedic work, entitled Cosmos, he articulated the process by quoting from a German critic who had observed of Shakespeare, "the descriptions of natural objects become as it were only mirrors in which the mental emotions of the actors in the scene are reflected". 52 But the delight which Humboldt takes in the sight of the animals drinking on the Orinoco bank (despite his awareness of the unidyllic reality) is in keeping with a much earlier observation of his on an animistic correspondence between subject and object. "The inward mirror of the sensitive mind", he writes, "reflects the true and living image of the natural world." From which it follows that a "free and vigorous setting" stimulates a spirit of adventure, and that "distant richly endowed lands" convey "the earlier youthful age of mankind". 53

Long before the separate components of his theory dove-tailed together to inspire The Origin of Species (I859) Darwin, like Humboldt, had travelled into the past as an explorer. For while it is true that numerous scientific works, notably Lyell 's Principles of Geology (I83I-3), 
impart a specialized bias to the observations recorded in The Voyage of the "Beagle" (I839), the concern with origins in this travelogue is typical of the explorer, and altogether endenic to the form. Like Wallis or Bougainville, Darrin sees in the Tahitian islanders "a fine picture of man inhabiting some primeval land". 54 Poised on a mountaintop he notes, like cook, 55 the excitement of being the first observer; and though granite meets his gaze and he wryly confesses to not being the first, what he sees is nonetheless "coeval with the beginning of the world".56 The disclosure of prehistoric forms arouses his imagination, and his writing is at its most charged when he describes a silicified forest, or a fog-bank that fortuitously restores an earlier level of the ocean. 57 The volcanic landmasses of the Galapagos islands constitute a turning point in the imaginative trajectory of his voyage, as also - it was to prove - in the development of his theory (for from his study of variation anong the finches there, he was later to infer the crucial concept of environmental modification). "Both in space and time," he writes of the archipelago, "we seem to be brought somewhat near to that great fact - that mystery of mysteries - the first appearance of new beings on this earth." 58 In the "retrospect" to his travelogue, Darwin accounts for his intense delight in the life of exploration in a way that develops Humboldt's equation of the exotic with the youthrul:

It has been said, that the love of the chase is an inherent delight in man - a relic of an instinctive passion. If so, I am sure the pleasure of living in the open air, with the sky for a roof and the ground for a table, is part of the same feeling; it is the savage returning to his wild and 
native habits. I always look back to our boat cruises, and my land journeys, when through unfrequented countries, with an extreme delight, which no scenes of civilization could have created. I do not doubt that every traveller must remember the glowing sense of happiness which he experienced, when he first breathed in a foreign clime, where the civilized man had seldom or never trod. 59

But just as Le Vaillant's self-emancipation left its impression on his view of indigenous people, so Darwin's recovery of an instinctual life is reflected in his alignment of the primitive with the wild:

I do not believe it is possible to describe or paint the difference between savage and civilized man. It is the difference between $a$ wild and tame animal: and part of the interest in beholding a savage, is the same which would lead everyone to desire to see the lion in his desert, the tiger tearing his prey in the jungle, or the rhinoceros wandering over the wild plains of Africa. 60

But while the projection of a liberated self supplies a common pattern, Le Vaillant and Darwin celebrate very different values through their spurious embodiment of the natural. For Le Vaillant the natural upholds, miraculously, a model of both personal and social harmony. For Darwin it denotes instinctual forces which threaten polity, but vitalize the individual. Yet for then both an urge to equate the unfarailiar with the original distorts perception of the exotic people they encounter.

Myths of creation are multifarious but, as far as Western culture is concerned, Genesis and physical evolution pretty well subsume the various kinds. The differences between the two are, of course, radical. 
Where the first provides for a universe created for once and all, its categories fixed and instinct with design, the second postulates the continuous development of new forms arranged in layers of ascending complexity. In the exchange of theory for doctrine, the old hierarchy is thrown into a temporal perspective and its order reversed. Descent from God gives place, on the new model, to an unfinished ascent from the lowest reaches of creation. The Ladder of Perfection - to make the point graphically - is chopped in half and turned upside down. To the layman seexing marks of origin in the external world, the most obvious difference between the two accounts lies, perhaps, in the contrast between their static and dynamic character. The Book of Genesis had ordained a single steady state; but the nascency posited by science declared itself in successive states, and implied a locus of endless vicissitude. Among many repercussions the scientific theory complicated the bearing of the present upon the past: on the one hand history was present in the fossil deposits which could be placed in temporal sequence by the palaeontologist; on the other hand the relationships between living forms themselves held the key to physiological change. Often under only the most tenuous of scientific cover, odd beliefs about the immanence of the past gained currency. According to a biogenetic theory, dating back to the late eighteenth century but first acquiring empirical pretensions in the third quarter of the nineteenth, ${ }^{6 I}$ each stage of evolution was rehearsed by the human footus in the course of its growth. While in this, as well as in many other ways, the development of each individual was seen to recapitulate that of the kind - "ontogeny" seen to "repeat phylogeny" to use the contemporary phrase - phylogeny in its 
turn was telescoped into the present through a variety of racial dogmas. These proceeded on the assumption that all evolutionary process was single and uniform, and lined up exotic cultures as if they were so many specimen fossils of vanished stages in the development of Western man. 62

Given the drastic implication of the shift in world view that ocourred in the nineteenth century, it might seen that the respective mental operations entailed by the quest for genesis in the external world were so distinct as to belong to an entirely different order. But if we return to the figure of the explorer, and consider the matter existentially, we shall see that this is not so. The point is perhaps best made by insisting on the evolutionary tendencies that pervaded the moral and social - indeed all but the cosmological - aspects of Judaeo-Christian belief itself. Traditionally the categories of physical creation (if not its nature) were held to remain static, but man had decisively fallen, and had fallen only to be re-engaged in an unfolding drama of redemption. Accordingly, for the traditionalist as much as for the evolutionary thinker, the notion of genesis readily transformed into a sense of buried potential in the self. And although from the turn of the eighteenth century (the period which constitutes a watershed in the rise of evolutionary thought) an emphasis on the self as many-layered became increasingly pronounced, this only extended an already assumed correspondence between the inner and outer worlds. Whereas to Le Vaillant an unspoilt landscape responded to a source of innate goodness in the corrupted self, for Emerson the "concentrical ... geological structure of the globe" provided the appropriate metaphor for the 
human mind, seen as impenetrably deep yet discontinuous. ${ }^{63}$ In the case of Leichhardt, an Australian explcrer enthralled by evolutionary geology that preceded Darwin, an almost obsessive interest in stratification tallies with his claim that year after year of his past unfurled as he penetrated the Centre:

As I proceeded on my journey, events of earlier date returned into my mind, with all the fantastic associations of a dream; and scenes of England, France, and Italy passed successively. Then came the recollections of my University life, of my parents and the members of my family; and, at last, the days of boyhood and of school - at one time as a boy afraid of the look of the master, and now with the independent feelings of the man, communicatins to, and discussing with him the progress of my journey, the courses of the rivers I had found, and the possible advantages of $\mathrm{my}$ discoveries. At the latter part of the journey, I had, as it were, retraced the whole course of my life. 64

Later in the century this pattern of personal reclamation would be extended to incorporate exotic cultures, and to include animal, vegetable, and even inorganic creation. ${ }^{65}$ Under the stimulus of evolutionary theory, the psjche as much as the external world was viewed as the accretion of previous states. No lapse in historical continuity is implied by this, however: for to the traditionalist the image of paradise corregponded to an unfallen state of the soul, obscured - but not irrecoverably so - by original sin. 66

Given that genesis, on either model, implies a process of uncovering a hidden self, let me ro-open the issue posed at the start, the relation of projection to genesis; and return to the question of what it is 
that leads explorers to searci for the evidences of creation in the external world. To this question two answers have already proposed themselves - first, the need to found a prescriptive system in the natural world; second, the transference of a perceptual freshness to the object. Though both these answers touch on the occupational circumstances of the explorer (as a person who ventures beyond the realm of polity in search of new things) and involve projection (since in each case mental concerns are located in the external world), nelther touches on the nature of projection itself. But in accordance with my original aim of showing an intrinsic connection between this process and the concern with genesis I shall now turn to one that does, even though it implicates the explorer only in so far as projection is least impeded when it engrosses the unknown.

Virtually by definition, to project is to be unaware of importation. Ideas that are fully owned do not belong to external objects: those that appear to are likely to surprise their engenderer. In its special psychoanalytic usage introduced by Freud, the term is exclusively reserved for unconscious ascription, and associated with censorship. Hence Charles Rycroft in a dictionary entry supplies the gloss: "projection of aspects of oneself is preceded by DENIAL, i.e. one denies that one feels such and such an emotion, has such and such a wish, but asserts that someone else does". 67 Since, like a dream, it gives expression, however disguised, to what the conscious mind censors, projection in this special context comprises the first step in a return of the repressed. But over a wider sphere it preserves its function 
as a vehicle of self-divulgence. For, from the object which has drawn a fully charged response, the conscious mind can retrieve what time and habit, as well as censorship, have effaced. ${ }^{68}$ In view of its capacity for baring the hidden, projection constitutes a dreamwork of the daylight self.

For a model of this operation it is once again to literature that we need to turn. The famous passage from The Prelude in which Wordsworth describes his childhood experience of rowing across a lake by moonlight not only shows how projection serves as an instrument of self-disclosure, but relates this process to the act of exploration. 69 Led by a "Nature" which consists as much in inner impulse as external setting, the child begins his adventure by unmooring a boat, and this small social transgression unleashes a train of uncovenanted feelings which lead to a decisive recognition. Hordsworth begins, characteristically, with the experience:

One summer evening (led by her) I found

A little boat tied to a willow tree

Within a rocky cave, its usual home.

Straight I unloosed her chain, and stepping in

Pushed from the shore. It was an act of stealth

And troubled pleasure, nor without the roice

of mountain-echoes did my boat move on:

Leaving behind her still, on either side,

Small circles glittering idly in the moon,

Until they melted all into one track

of sparkling light. But now, like one who rows, Proud of his skill, to reach a chosen point

With an unsierving line, I fixed my view 
Upon the sunmit of a craggy ridge,

The horizon's utmost boundary; far above

Has nothing but the stars and the grey sky.

She was an elfin pinnace; lustily

I dipped my oars into the silent lake,

And, as I rose upon the stroke, my boat

Went heaving through the water like a swan;

When, from behind that craggy steep till then

The horizon's bound, a huge peak, black and huge,

As if with voluntary power instinct,

Upreared its head. I struck and struck again,

And growing still in stature the grim shape

Towered up between me and the stars, and still,

For so it seemed, with purpose of its own

And measured motion like a living thing,

Strode after me. With trembling oars I turned,

And through the silent water stole my way

Back to the covert of the willow tree.

The unmooring is defined as an act of stealth, but registered also as an act of release through the terms applied to the boat, which leaves home, freed of its chain. This poetic transference is the first of many through which Hordsworth dramatizes the sensations of the child, and it is a figure appropriate to his original experience, for from the point of view of the boy, locked in the grip of panic, terror is located in the external scene itself. For him it is the mountain that voices the sounds of his own making; the huge peak that rises and, as he flees, pursues; the oars that tremble. But the singleness of the child's experience is conveyed to the reader through the mature consciousness of the narrator who, even as he conjures up a scene which abets illusion, demonstrates the tricks 
of parallax and referred motion:

When, from behind that craggy steep till then

The horizon's bound, a huge peak, black and huge,

As if with voluntary power instinct,

Upreared its head. I struck and struck again...

Even the serpent-like aspect of the peak receives its force from the rower's action ("upreared" : "struck"). Yet Wordworth leaves us in no doubt that in the throes of sensation he was blind to his own agency, unaware even of the way in which his flight created pursuit, or his fear an object of terror:

and still,

For so it seemed, with purpose of its own And measured motion like a living thing, Strode after me.

He seems, moreover, to relate this sheer externality to a dread of adritting feelings of fear and awe. For no sooner is the boat unchained than the poet shows how the boy keeps his responses in check. As so often in Wordsworth's poetry the double negative in "nor without the voice" is pointed: by hinting at the relief of silence it suggests that the sounds are unwelcome, and that the attention of the boy is selective. The troublesome echoes cannot, like the water, be left behind bit they are soon displaced by a reassuring impression - the moonlit wake receding into steadiness. Then, almost it would seem as a planned diversion from his latent unease, the boy (- "like one who rows,/ Proud of his skill, to reach a chosen point / With an unswerving line") imposes the form of a game 
on his venture. Even the summit of the craggy ridge is pressed into service as a beacon. And only once the space within the "horizon's bound" has been conquered in this way, by reason and by will can he freely revel in a scene to which stars, a grey sky, the image of a swan, and some ornate poetic diction ("elfin pinnace") lend the aura of an idyll. When, because of its greater height and the ever-increasing distance, a further peak begins to rise beyond the frame of the ridge, his composure is instantly shattered.

As Wordsworth turns to the reflective impact that the experience had on him as a boy, the expanding horizon that dominates the action in the first half of the paragraph converts into a metaphor for self-discovery, and the work of projection is carefully dismantled. Answering the "huge and mighty forms" of an interior landscape the once hidden peak (twice described as "huge") now takes its place in a fresh map of the psyche:

$$
\text { for many days, my brain }
$$

Worked with a dim and undetermined sense of unknown modes of being; o'er my thoughts There hung a darkness, call it solitude Or blank desertion. No familiar shapes Remained, no pleasant images of trees, of sea or siy, no colours of green fields; But huge and mighty forms, that do not live Like living men, moved slowly through the mind By day, and were a trouble to my dreams.

The setting sparks off a psychological recognition. But the rendering of the inner world remains colourless, and comparatively vague, so 
that we are grateful for the further layer of reflection supplied in the paragraph that follciws. Here Wordsworth celebrates his acceptance of "the passions that build up our human soul", adding that it was in the absence of "the mean and vulgar works of man" that he learnt to "[sanctify] both pain and fear". The notion of escape from a constricting social consciousness proves central in a variety of ways. If the passage displays two facets - the one adventurous, the other diagnostic - each reflects an instance of truancy, as appears from the way the exploring, and projecting unfold in parallel. Lea by nature into conflict with taboo, the boy unchains the boat from its usual home, and ventures out to discover a peak beyond his ken. The emotions with which he invests this peas underso a similar enfranchisement: apparently extraneous to the daylight world of men, they break through the defences of censorship with sufficient force to be identified and fully owned.

Projection (when followed through, at least, to the point of analysis) finds an apt metaphor in exploration, for both involve the recovery of what exists but remains hidden beyond the realm of the known. Yet al though there is a real, though limited, sense in which emotions and desires precede the objects which excite their expression, they cannot be defined without these objects, any more than a planet as Feuerbach once observed - can be understood without its sun. His remark prefaces a penetrating comment on the heuristic potential of the external world: 
In the object which he contemplates, therefore, man becomes acquainted with himself; consciousness of the objective is the self-consciousness of man. We know the man by the object, by his conception of what is external to himself; in it his nature becomes evident ... Even the objects which are the most remote from man, because they are objects to him, and to the extent to which they are so, are revelations of human nature.

Feuerbach goes on to align man's nature with his origin:

The eje which looks into the starry heavens, which gazes at that light, alike useless and harmless, having nothing in common with the earth and its necessities - this eye sees in that light its orm nature, its own origin. 70

How we came to be deternines what, beneath the skin, we are - the idea dies hard, for the sense of an essential human identity, underlying the changing faces of polity, is something to which every version of genesis infallibly gives rise. It is for this reason that there is only a short step between searching unexplored places for vestiges of the primeval, and finding in them symbols of the unconscious mind. Because the process of projection provides a means to baring a hidden self,it has served as an analogue as well as a vehicle to the revelatory myths of creation. 
If his first narrative is viewed as the start of a new kind, Defoe appears to have fathered both realist fiction and the novel of exploration at a single stroke. In fact his parenthood is more obvious in the case of the sub-genre. For while Robinson Crusoe (I7I9) centres in the lone hero, and so hardly touches on those "social and relative duties" which were to provide the stuff of the mainstream novel from Richardson onwards, there is scarcely a story dealing with the exploits of either adventurers or castaways which does not bear the mark of its influence. I Models for the restless spirit that keeps Crusoe on the move, even once he is stranded, have never been lacking; but when it oame to the shaping of his tale Defoe left an imprint that was to prove indelible. Crusoe finds himself cut off from society, undergoes a period of growth in a fresh environment and finally returns home. This three-stage plot became conventional to the adventure story, and wherever we encounter it we are likely to come across some allusion to Crusoe. Defoe's other and more famous legacy, his contribution to the realist novel, needs no rehearsing. ${ }^{2}$

Because of its double lineage Robinson Crusoe demarcates common ground between concerns that are special to exploration and perennial to the novel as a whole, and it may well be an indication of the firmness of this ground that works such as Noby Dick, Heart of Darkness, or Voss rate as classics of the wider genre. There seem, in fact, to be three main points at which Defoe's adventure story 
abuts on the central tradition. Firstly, Crusoe poses a question typical of the explorer when, pondering the mysteries of genesis, he asks "what am I, and all the other Creatures?" (p.92). ${ }^{3}$ The question reaches deeply into the text as we shall see, and it is certainly one kept alive by the work of major novelists. Then, eccentric though his treatment of the issue may be (he seems out to show at times that solitude is man's proper state)

Defoe uses the solitary situation of his hero as a base from which to investigate the rival claims of independence and relation, a theme as important later to, say, Women in Love as to Voss. Lastly, it is certainly true that one of Defoe's most forceful contributions to the rise of the novel lay in his creation of what Pat Rogers has called the narrator's "sustained intimacy" of address. 4 Here, again, it seems to have been in response to the challenge of his hero's isolation that Defoe pioneered new routes of access to inner states, and he was well served in this regard by the projective procedures that characterize travel writing. It is with the last of these three areas of interest that I shall more particularly be concerned, for my chief aim is to examine the way Defoe objectifies the inward tendencies of his hero through his use of setting.

After six years of uninterrupted solitude on the island, and a month or two of absence from his second dwelling Crusoe is woken from the rest the takes, on his return there, by a voice that insistently moans, "Robin, Robin, Robin Crusoe, poor Robin Crusoe, 
where are you Robin Crusoe? Where are you? Where have you been?" (p.I42). Although the words are really his own, since he himself has put them into the mouth of his parrot, Crusoe fails to recognize them and, slipping back into sleep, imagines that it is a man who calls out to him, and speaks. His attitude to this figure proves ambivalent. Reassurance rapidly gives way to fright in his dream until he wakes, for a second time, in a state of panic only to hear his repertoire of self-pity relayed by his pet. The peculiar quality of this parrot-talk becomes evident to Crusoe at the moment he places the voice:

no sooner were my Eyes open, but I saw my Poll sitting on the Top of the Hedge; and immediately knew that it was he that spoke to me; for just in such bemoaning Language I had used to talk to him, and teach him.

For the first time Crusoe takes in, as if from an external source, the plaintive phrases which, only half-consciously it appears, he has confided in hirself or in Poll over the years. Just as in the course of his oircumnavigation of the island (the episode that immediately precedes his return to the bower) Crusoe adopts a fresh perspective towards his "captivity", so now he learns to view his former condition from the outside. Like the dictaphone in Krapp's Last Tape the parrot begins as an instmument of self-expression and ends as a means of self-disclosure. As a mark of his eerie recognition Crusoe reports that he continues to be disturbed by the incident after his practical fears have been allayed. 
The parrot-sequence is a tour de force as Defoe certainly knew for he advertises it in advance and keeps Poll conspicuously posted. 5 But although "very diverting" the scene is also functional, gathering, as it does, several of the novel's chief themes into vivid relation. Both Crusoe's latent craving for human society and his recoil from it are embodied in the man he creates from the parrot in his sleep; and this figure looks forward to the later dream in which he pictures the companionship of a victim rescued from a cannibal horde (pp.I98-9). In Friday he finds - once this dream has come to pass - a being who can fully occupy the role in which a succession of pets have fallen short. The first of these, the dog he saves from the wreck and values as a "trusty servant", has one shortcoming:

I wanted nothing that he could fetch me, nor any Company that he could make up to me, I only wanted to have him talk to me, but that would not do.

The parrot has the advantage, here, in catering more completely to Crusoe's need:

the sociable Creature came to me, and sat upon my Thumb, as he used to do, and continu'd talking to me... just as if he had been overjoy'd to see me again.

One favourite supplants another, and the moment Friday speaks Poll's accomplishments are forgotten. Before he finds his companion and has done with pets, however, Crusoe makes up for deficiency with number until he has surrounded himself with a "family" of creatures - dogs, cats, sea-fowl, 
parrots and kids - each allotted a regular place at his household table (pp.I47-8). Hhen Friday arrives on the scene he is taught to address Crusoe as "master", and generally referred to as "my man". He gives a literal sense to the metaphors of servitude applied to every pet in turn, but never quite transcends the portion of his predecessors. Seldom is he more acceptable than when approaching his rescuer with gestures of fawning submission (p.206); and Crusoe is soon to take his surrender of will for granted: "I took him out with me", he will write, or again, "Having thus fed him with boil'd Meat and Broth, I was resolv'd to feast him the next Day" (pp.2IO-II,2I2). A continuity between Crusoe's education of Friday and his taming of creatures from the wild is apparent fairly often.

The relationship with Friday represents the fullest expression of Crusoe's desire for company, and he insists, nevertheless, on the strength of his social passions time and again. He describes, for instance, how overwrought with disappointment, he falls into a trance after the disappearance of the Spanish ship, constantly chanting, "으 that it had been but One!", until his hands and mouth fasten in a convulsive clench (p.I88). Crusoe's social desires are, of course, of a limited kind. Like of most of Defoe's heroes he never betrays a flicker of sexual response, managing even to keep the report of his marriage to a single sentence so that Mrs Crusoe dies on a participial phrase embedded within a subordinate clause (p.305). In any case we are left in no doubt that his relationship with Friday comprises the culmination of his social life: 
the Conversation whioh employ'd the Hours between Friday and I, was such, as made the three Years which we liv'd there together perfectly and compleatly happy, if any such Thing as compleat Happiness can be form'd in a sublunary State. $(\mathrm{p} .220)$

Nor is it by chance that this specially fulfilling bond should be of a master-servant kind, for throughout the text Crusoe's thirst for relation is countered by his delight in autonomy. Whenever he thanks God for making life on the island "better than sociable" (p.I35) his independence is not far from view and it amounts, as he once explains, to nothing less than sovereignty:

I had nothing to covet; for I had all that I was now capable of enjoying: I was Lord of the whole Mannor; or if I pleas'd, I might call my self King, or Emperor over the whole Country which I had Possession of. There were no Rivals. I had no Competitor.

The itch for self-determination is with Crusoe from the start: it is no other than the happy "original sin" which prompts him to "act the Rebel" to his father, and to shy away, twice over, from "the middle state" (pp.4,40,I94). He can understand his confinement on the island as a punishment for transgression precisely because it comes as the consequence of his resistance to "confin'd Desires" (p.I94). When he finds the footprint, the prospect of human presence is wholly soured by the lack of any compensating assurance of control. In context it is clear that Crusoe's relationship with Friday answers to the shape carved out by a confluence of warring 
needs. It represents a compromise between what he calls his "Desire after the Society of my Fellow-Creatures" (p.I88), and his urge to be monarch of all he surveys.

One reason why Crusoe, on returning to his bower, is slow to recognize Poll's sad refrain, is that in the course of his voyage round the island he undergoes a change of mood. No sooner has he been swept into a dangerous current than daily existence appears to him in a favourable light:

Now I look'd back upon my desolate solitary Island, as the most pleasant Place in the World, and all the Happiness my Heart could wish for, was to be but there again.

It is while bathed in the afterglow of these sentiments that he hears Poll relaying the litany of his gloom, "Poor Robin Crusoe, Where are you? Where have you been?". Ambivalence is a feature of Crusoe's experience as much as it is the mental habit of his schizophrenic creator, and it would certainly be extravagant to suppose that every antithetical movement of the narrative adds to a design. All the same, this particular antinomy in Crusoe's reading of his situation is an important one, for it not only ramifies through the novel so as to produce, as Carnochan has noted, the sense of two distinot islands; ${ }^{6}$ but also points back to the decisive change of outlook that attends Crusoe's religious conversion. In short, the "Island of Despair" - the phrase confided to his journal (p.70), and the "pleasant Place" that he sees (yet 
again) from the ocean, are used to denote the "before" and "after" of his repentance.

The impressions Crusoe forms of his island are mixed from the outset, and so they continue to be,for they are founded in the paradox of his solitary state. The volatile bouts of joy and terror he experiences on landing (sensations so intense, he notices, as to be equally overwhelming,pp.46-7) give way to feelings that are more stable and prolonged, so that he is soon able to analyse the causes of his fluctuating moods by drawing up a table in which he enters the good against the evil aspects of his plight. This table shows Crusoe simultaneously elated and depressed by the fact that he is sole survivor. If it is reason for joy that he alone of the crew should have been saved it is no less a cause for terror that, stripped of all companionship, he should face the undisclosed dangers of his new world without any aid. He is at once the miserable solitaire banished from society to fribble away a hopeless life, and the lucky man singled out to make the most of a pleasant setting. For Crusoe solitude holds two faces, and both are reflected by the island when he sees it for the first time from the crest of a hills

after I had with great Labour and Difficulty got to the Top, I saw my Fate to my great Affliction, (viz.) that I was in an Island environ'd every Way with the Sea, no Land to be seen, except some Rocks which lay a great Way off, and two small Islands less than this, which lay about three Leagues to the West.

I found also that the Island I was in was barren, and, as I 
saw good Reason to believe, un-inhabited, except by wild Beasts, of whon however I saw none, yet I saw Abundance of Fowls, but knew not their Kinds, neither when I kill'd then could I tell what was fit for Food, and what not; at my coming back, I shot at a great Bird which I saw sitting upon a Tree on the Side of a great hood, I believe it was the first Gun that had been fir'd there since the Creation of the World; I had no sooner fir'd, but from all the Parts of the Wood there arose an innumerable Number of Fowls of many Sorts, making a confus'd Screaring, and crying every one according to his usual Note. $(\mathrm{pp} .52-3)$

When Crusoe confirms from his vantage point that he is indeed on an island, renewed despondency clouds his response to the scene. So he is the prisoner of his landscape, "environ'd every Hay with the Sea"; the place "barren", and full of "wild Beastg". But even while recording this impression, Crusoe pauses to note some anomalous details. Al though there is "no Land to be seen" he makes a point of mentioning two islands which lie at no great distance to the west; or, again, admits that he has no reason to assume the presence of the beasts - "however I saw none". Despite himself Crusoe thrills to his surroundings and, as his attention is increasingly absorbed by the foreground, soon forgets that he is on an island at all. But while he is impressed by the abundance of wildfowl and rejoices in the great size of a bird, or of the wood, he makes no attempt to disguise the source of his feeling, the power he enjoys over everything in range. Indeed, as the paragraph reaches to a climax with the firing of his gun, he quietly acknowledges 
that his inheritance is nothing less than a world still fresh from God's creation. He relishes the terror of the wheling birds and remembers, at the same time, to notice the variety of their kinds. It is with disturbing rapacity that Crusoe acts out Marvell's dream of living in Paradise alone.?

In little more than a paragraph Crusoe shifts between his oustomary states of grief and contentment, states that relate directly to the interplay of his warring needs. On the one hand, the island frustrates his need of sooial intercourses it gives free reign to his love of power on the other. Yet although it is plain to every reader that Crusoe is subject to wavering moods throughout, in his retrospect of his first two jears on the island he presents his experience of despair as the distinotive trait of his unregenerate days

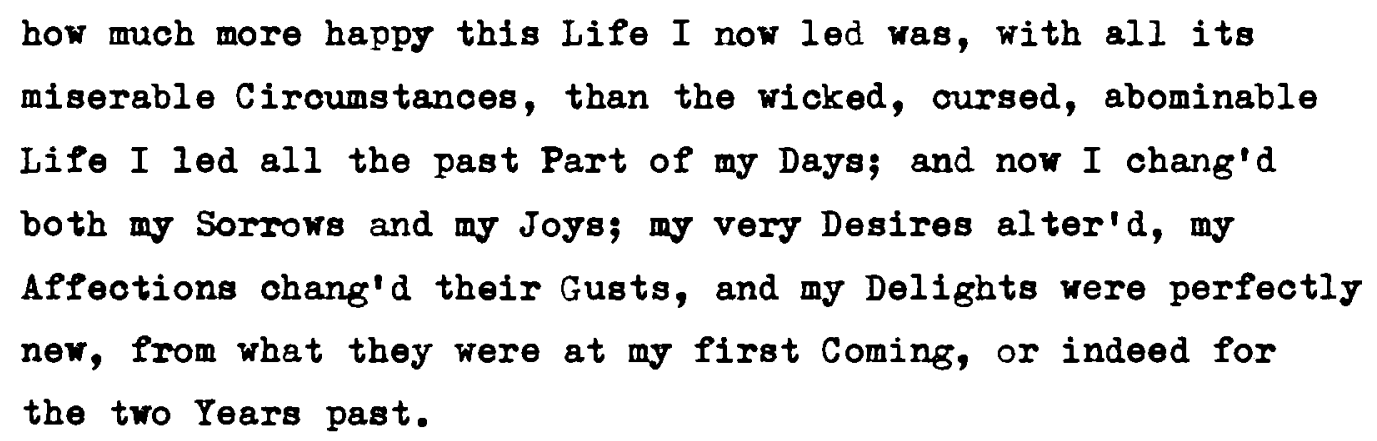

He proceeds with an account of what he has called the Island of Despair, now identified as a symptom of his sin:

Before, as I walk'd about, either on my Hunting, or for viewing the Country, the Anguish of my Soul at my Condition, would break out upon me on a sudden, and my very Heart would 
die within me, to think of the Woods, the Mountains, the Deserts I was ing and how I was a Prisoner look'd up with the Eternal Bars and Bolts of the Ocean, in an uninhabited Wilderness, without Redemptions In the midst of the greatest Composures of my Mind, this would break out upon me like a Storm, and make me wring my Hands, and weep like a Childs Sometimes it would take me in the middle of my Work, and I would immediately sit down and sigh, and look upon the Ground for an Hour or two together; and this was still worse to me; for if I could burst out into Tears, or vent my self by Kords, it would go off, and the Grief having exhausted it self would abate.

(pp.II2-I3)

Here Defoe enlarges on his hero's isolation with a metaphorio force that is unusual in his writing, and once again it is the experience of a vast expanse ("the Woods, the Mountains, the Desarts") bearing in on the frail, exposed soul, that epitomizes Crusoe's sense of claustrophobic confinement, an irony driven home by the phrase, "the Eternal Bars and Bolts of the Ocean". It is not surprising to find a similar oxpmoron used, in an address by a Puritan spokesman, to describe the sinking spirits of the P1lgrim Fathers on reaching America?

If they looked behind them, there was the mighty ocean which they had passed and was now as a main bar and gulf to separate them from all the civil parts of the world. 8

Unsurprising in that Defoe continually relates his imagery of imprisonment to the Book of Exodus, an episode of Biblical history that has always held strong appeal for the Nonoonformist mind. 
Shortly before he prays for the first time in "the true sense", Crusoe alights on a text,"Can God spread a Table in the Wilderness?", which, in common with most of the scriptural allusions in this part of the novel, refers to Moses's deliverance of the Israelites from Egyptian bondage. Even his moment of conversion is couched in the same terms:

Now I began to construe the Words mentioned above, Call on me, and I will deliver you, in a different Sense from what I had ever done before; for then I had no Notion of any thing being call'd Deliverance, but my being deliver'd from the Captivity I was in; for tho' I was indeed at large in the Place, yet the Island was certainly a Prison to me, and that in the worst Sense in the Norld; but now I learn'd to take it in another Sense: Now I look'd back upon my past Life with such Horrour, and my Sins appear'd so dreadful, that my Soul sought nothing of God, but Deliverance from the Load of Guilt that bore down all my Comfort. (pp.96-7)

We shall see that Crusoe ultimately reverts to the darker view of his situation but, after his repentance, he seldom fails to recognize that his Island of Despair proceeds from a state of mind, whereas in his journal it is the name of a place. He can now artioulate the processes of projection that colour his surroundings. Though the footprint throws him into a panic he is quick, as narrator, to account for the distorting effects of his fears

I came Home ... but terrify'd to the last Degree, looking behind me at every two or three Steps, mistaking every Bush and Tree, and fancying every Stump at a Distance to be a Man; nor is it possible to describe how many various Shapes affighted Imagination represented Things to me in. 
If Defoe was not familiar with Theseus's speech on the "shaping fantasies" of poets, lovers and madmen he was certainly aware of the tricks played by the mind on perception; ${ }^{10}$ and it is in the light of this arareness that he uses physical setting, throughout Robinson Crusoe, as a sort of litmus-paper test of his hero's spiritual condition. The island captures Crusoe's inner feelings as deftly as the parrot.

Robinson Crusoe has its roots (as has often been remarked) in several distinot, literary traditions, foremost among which are spiritual autobiography and the travel book. Though Defoe is widely known as the father of the English novel this claim is a paradoxical one, for it was precisely his avoidance of the seemingly fictitious that distinguished his work from the host of romances and novellas produced before his time. Because he meant to pass off his first narrative as a true story, Defoe did his best to mimic the materials and procedures of a travelogue. But in overall form Robingon Crusoe orres a great deal, as George Starr has conclusively shown, to the then popular genre of the religious confession, with its standard progress from fall to repentance, from newfound grace to renewed tribulation. II It is, of course, in the nature of this mixed heritage that Crusoe should switch his attention from God to cassava root but although the confessional pattern predominates here as nowhere else in Defoe's narratives - there is some force in the point made by a contemporary critic who, framing an imaginary dialogue between character and author, had Crusoe complain, 
when you bring me again to a Sense of the Want of Religion, you make me quit that upon every Whimsy. I2

Certainly the novel's many seams sometimes prove a source of strength, and the treatment of Crusoe's fluctuating moods presents a case in point. Here, what spiritual autobiography puts asunder Defoe joins together, and psychology is surely on his side. Aoquired some time after her master's conversion, Poll supplies one of many welcome reminders that not all has been rosy in Crusoe's regenerate phase.

It would not do, however, to underestimate the feats of fusion that went into the making of the narrative. We have seen how Defoe uses the imagery of imprisonment to link his hero's despair with the concerns of Exodus: he draws at the same time both on the reports of travellers, and on a tradition of moral allegory which he may well have tapped from Bunjan. In the course of his progress Bunyan's Christian is introduced to a man who sits in a dark room, murmuring, "I am what I was not once":

Chr. Nell, but what art thou nor?

Man. I am now a Man of Dispair, and am shut up in it, as in this Iron Cage. I cannot get out; 0 now I cannot. Chr. But how camest thou in this condition?

Man. ... I have so hardened my heart, that I cannot repent. I3

Like Mr Fearing whom Christian encounters later on his journey, stuck as always in the mud - for he has a "Slough of Despond in his Mind, a Slough that he carried every where with him, or else he could never have been as he was" - the figure of Despair is insulated from change 
by his own condition. I4 Crusoe, in just the same way, is cut off from "all Manner of Opportunities to converse with any thing but what was like my self", because of his "hardned Life" (pp.I3I-2).

Defoe's debt to the various accounts of Alexander Selkirk has always been recognized, but the close correspondence between Crusoe and the castaray's spiritual ups-and-downs has not received its due of critical attention. I5 Woodes Rogers, the captain responsible for rescuing Selkirk after his self-inflicted spell of four years on Juan Fernandez, lays considereble stress on the initial period of depression suffered by the mariner:

He diverted and provided for himself as well as he could, but for the first eight months had much ado to bear up against melancholy, and the terror of being left alone in such a desolate place. I6

Crusoe's blue period is of much the same duration for, al though his release from the captivity of sin takes place in his tenth month on the island, the train of events which lead to his conversion - the miraculous sprouting of the corn, the earthquake, his dream of the avenging angel, and his illness - dates back to his seventh. Equally pertinent is the description Rogers supplies of the way Selkirk overcame his melancholy by reading from the Bible, praying and chanting psalms. "He was a better Christian while in this solitude", he adds, "than ever he was before, or than, he was afraid, he should ever be again." ${ }^{I 7}$ According to Rogers, Selkirk was saved from utter desolation by the renewal of his faith and by the company, also, of his 
kids and oats with whom "he would, now and then, sing and dance". I8 Richard Steele in his version of the story, gathered from conversations with Selkirk after his return, adopts the same emphasis: he distinguishes between the isolato's periods of "dissatisfaction" and "delight", attributes his triumphs over despair to "Foroe of Reason, and frequent reading of the scriptures", and enlarges on his impulsive urges for society. I9 But Steele is at his most germane when he explains how Selkirk's change of heart altered his outlook towards the ieland:

I forgot to observe, that during the Time of his Dissatisfaction, Monsters of the Deep, which frequently lay on the Shore, added to the Terrors of his Solitude; the dreadful Howlings and Voices seemed too terrible to be made for human Ears; but upon the Recovery of his Temper, he could with Pleasure not only hear their Voioes, but approach the Monsters themselves with great Intrepidity. Be speaks of Sea-Lions, whose Jaws and Tails were capable of seizing or breaking the Limbs of a Man, if he approached them: But at that Time his Spirits and Life were so high, and he could act so regularly and unconcerned, that meerly from being unruffled in himself, he killed them with the greatest Ease imaginable. 20

The accounts of Selkirk show not only how much Defoe took from actual experienoe but how well he grafted on the literary conventions that extend the range and finesse of his sources. We have seen how Selkirk's importation of terror is diversified in numerous ways throughout the text. The means by which Defoe expands on the "unruffled" spirits which led Selkirk to a new understanding with his environment remain to be examined. 
So long as he is the prisoner of his Island of Despair Crusoe remains fairly static, never venturing beyond a few hours' hike of his fortified drelling. Confinement is his punishment for unconfined desires, and his exodus from bondage remains purely metaphorical until, with his recovery and conversion complete, we sets out for the first time to explore. Moral progress is now manifest in the journey he takes into the interior. Moving through ever richer country he is surprised, at the close of his second day, by a Pisgah-like view of his future domain:

At the End of this March I came to an Opening, where the Country seem'd to descend to the West, and a little Spring of fresh Water which issued out of the Side of the Hill by me, run the other Way, that is due East; and the Country appear'd so fresh, so green, so flourishing, every thing being in a constant Verdure, or Flourish of Spring, that it looked like a planted Garden.

The date is mid-July and by any reckoning Crusoe is north of the equator, so the reference to foliage as fresh and as green as that of Spring (the italics are Defoe's) underlines his sense of a landscape unspoilt by the Fall, an idea made virtually explicit by the "planted garden" that supplants his earlier impression of wilderness. On the walk made before his conversion Crusoe notices a scene untouched "since the Creation" but his recognition is comparatively casual: the overt delight he now takes in the prospect before him serves as an indication of his renewal. In the terms of Pope's paradoxical "scene of Man" Crusoe wins an insight, for the moment, into nature's hidden order: 
A mighty maze! but not wi thout a plan;

A Vild, where weeds and flow'rs promiscuous shoot, Or Garden, tempting with forbidden fruit. ${ }^{2 I}$

Defoe sees to it, of course, that the surfaces of realism are kept intact. Like any explorer Crusoe worries over his oo-ordinates (if the valley stretohes north, the brook runs due east), but there is no mistaking the allegorical features of his map. The melons and olustering vines are observed with a freshness of detail that suggests they may have been taken straight from Hakluyts 22

in this Part I found different Fruits, and particularly I found Mellons upon the Ground in great Abundance, and Grapes upon the Trees; the Vines had spread indeed over the Trees, and the Clusters of Grapes were just now in their Prime, very ripe and rich.

But the composition as a whole belongs to the machinery of fable. Crusoe is in the position of Bunyan's Christian, rewarded at length by the Delectable Mountains, some time since he has caught his first glimpse of their uplifting terrain:

and behold at a great distance he saw a most pleasant Mountainous Country, beautffied with Woods, Vineyards, Fruits of all sorts; Flowers also, with Springs and Fountains, very delectable to behold. 23

Only after he has escaped from the dungeon of Giant Despair does Chrlstian reach these hallowed slopes, there to refresh himself with the fountains and fruit. ${ }^{24}$ But al though Crusoe's progress follows the main lines of this episode we have only to turn back to the text 
to see how Defoe throws Bunjan's pasteboard setting into vivid relief.

Before he has picked more grapes and limes than he can possibly carry (he resolves, however, to come back for the rest) Crusoe sounds the signature-tune of his happy island:

I descended a little on the Side of that delicious Vale, surveying it with a secret Kind of Pleasure, (tho' mixt with my other afflicting Thoughts) to think that this was all my own, that I was King and Lord of all this Country indefeasibly, and had a Right of Possession; and if I could convey it, I might have it in Inheritanoe, as compleatly as any Lord of a Mannor in England. (p.IOO)

Although he seems to show the awareness of some guilt in commenting on the furtive nature of his pleasure, Crusoe clearly experiences no real difficulty in reconoiling this new dispensation with his urge for sway. He will later present his authority as providential, and so close the gap between Adam's stewardship and that of a feudal lord. Though his affiotions still persist, they are now contained by parentheses - which points to his success in controlling the grief caused by his other (if lesser) ruling passion, his thirst for human society. On one occasion he volunteers a reason for this, explaining that his companionly urges are more than compensated by his closeness to God or by what amounts to much the same thing, introspection:

when I began to regret the want of Conversation, I would ask my self whether thus conversing mutually with my own Thoughts, and, as I hope I may say, with even God himself by Ejaculations, was not better than the utmost Enjoyment of humane Society in the World. 
Even in context this explanation appears somewhat strained. But Defoe does, in fact, manage to make his hero's release from solitude fairly convincing. We are led to feel, after his conversion, that Crusoe is no longer the embattled loner staring into the void. The confortable assurance with which he confides his experienoe contributes to the impression, but this holds true, of course, throughout. Defoe's immediate means are more abstract: he has his hero gaze at the sea, and ponder the mysteries of genesis. In defiance of his subjective imprisonment Crusoe is soon spelling out his belief in the kinship of all creatures, and considering his place in the divine plans

What is this Earth and Sea of which I have seen so much, whence is it produc'd, and what an $I$, and all the other Creatures, wild and tame, humane and brutal, whence are we?

Sure we are all made by some secret Power, who form'd the Earth and Sea, the Air and Skyz and who is that?

Then it follow'd most naturally, It is God that has made it all: Well, but then it oame on strangely, if God has made all these Things, He guides and governs them all, and all Things that concern them; for the Power that could make all Things, must certainly have Power to guide and direot them.

"Where are you?", and "How come you here?": in context Poll's cries have an almost metaphysical ring for they reverberate the rhetorical mode of Crusoe's meditations. Locke in a famous section of his Essay had asked whether a brainy parrot would count as a human. Defoe may well have been influenced by the passage but Poll plays her part in an account of human identity that is essentially novelistic. ${ }^{25}$ While she draws Crusoe into relation, as do the many other pets who come into focus after his repentance, she serves also to sharpen his yearning for 
the distinctively human - in his dream Crusoe will transform her voice into that of a person calling. The goat found in the cave performs much the same function. After likening the wretched animal to a moribund man ("just making his Will, as we say, and gasping for Life, and dying indeed of neer old Age", p.I78) Crusoe wryly entertains the thought of sharing its dumb acceptance,

I could have been content to have capitulated for spending the rest of my Time there, even to the last Moment, till I had laid me down and dy'd, like the old Goat in the Cave

and recovers his fighting spirits the sooner. Animals and objects keep Crusoe's spectre of exclusion at bay, and help him to affirm a sense of self.

After the conquest of his solitude Crusoe, like Silas Marner, develops an almost childlike trust in the goodness of creation. Indeed, the Fall seems not to enter account in either his thoughts on the origin of the world, or his viewing of the island as a "planted garden" on the excursion that shortly ensues. A gain in confidence is immediately reflected by the style of his life. He sets out to explore, and decides to prolong his trip over several days, happy for onoe to sleep under the sky. On returning to his old quarters whioh (placed in the lee of an escarpment, po.58-9) have served till now both as a shelter and lookout, he decides he can do without his elaborate system of defences, and so cuts a door through the rook of his cave. His comment on this occasion is telling: 
as I had manag'd my self before, I was in a perfect Enclosure, whereas now I thought I lay expos'd, and open for any Thing to come in upon me; and yet I could not perceive that there was any living Thing to fear.

(p.IO3)

Once his terrors are dispelled Crusoe is eager to spread his energies over the land and put down roots. In rapid succession we learn of the way he doubles his stook and grain, perfects his skill at making pots and bread, and - almost in a spirit of revelry - builds a second dwelling for himself. So resourceful does he prove that, in the course of a few months, he practically recapitulates the stages of economio advance Defoe was to set out in his general history of trade. 26 In keeping, moreover, with his belief that he contributes to a hidden order, the boundaries between the natural and artificial realms begin to recede. Taken from the woods, Poll learns to speak. Wild cats mate with the tame, and the stakes of his enclosure send out fresh shoots. For a while the notion of rebirth, figured in the coincidence of his birthday and landing, carries dramatic weight.

Conversion supplies one turning point in the narrative, the footprint another. The moment the mysterious mark appears all the old demons come trooping back. Bitterly regretting the passage he has carved out of his shelter Crusoe throws up yet a further ring of defence, "so monstrous thiok and strong, that it was indeed perfectly impassable" (p.I6I); but no matter how impregnable his fortresses are and he retreats into a series of them - Crusoe never feels safe. In ever narrowing horizons the wilderness reasserts its constriotive pressure until he half deoides to root up his fields in cese their 
presence should give him away. Looked at from a little distance, his programme for survival seems like a suicide plan.

That there is an element of hysteria in his actions Crusoe is ready to aoknowledge. He is equally concerned, however, to stress that his darker view of nature is founded in fact. The footprint turne out, accordingly, to be the token of a world that has suffered the Fall. It is a chastened Crusoe who refers to a "Nature entirely abandon' $d$ of Heaven", or to "Creatures ... senteno'd to Absence from himself" ( pp.I70,2I0). These remarks are occasioned, it is true, by the Carib tribe who visit the island to celebrate their rites; the second of them by Crusoe's grim discovery of leftovers from a oannibal feast. But with an irony that almost certainly derives from Montaigne, Defoe twice turns the tables on Europe. 27 He has Crusoe argue, first, that the horrors of the Inquisition easily outweigh pagan cruelty (p.244). Later, he braokets exotio and familiar forms of barbarity when Friday, naively inquiring whether the three Englishmen on the beach are to be eaten, learns that as victims of a muting they will be murdered (p.25I). It is noticeable, too, that al though Crusoe has no qualms about putting Friday through a homespun catechism, he often gets himself into doctrinal scrapes. When, for example, his bright pupil questions why an omnipotent God should permit evil he pretends, to begin with, not to hear and then fumbles badly for a reply (p.2I8). Again, when pondering why the new rorld should have been denied the means to redemption he is forced back on an uneasy championship of faith against reason (pp.209-IO, 2I9). 
Ultimately the darker world disclosed by the footprint works as a foil to offset the radiance of belief. Crusoe points to this conclusion when he observes that he was blessed by the benign insouciance instilled by his conversion:

Matisfaction was perfect, though my Danger was the same; and $I$ was as happy in not knowing my Danger, as if $I$ had never really been expos'd to it ... How infinitely Good that Providence is, which has provided in its Government of Mankind, such narrow bounds to his Sight and Knowledge of Things, and though he walks in the midst of so many thousand Dangers, the Sight of which, if discover'd to him, rould distract his Mind, and sink his Spirits; he is kept serene, and calm, by having the Events of Things hid from his Eyes, and knowing nothing of the Dangers which surround him.

As the gap between island and idyll widens, Defoe finds a practioal way of bridging the actual and ordained. Built up into something of a philosopher-king, Crusoe becomes an executive of the order he celebrates. The better to dispense justice to his world he appoints himself governor or generalissimo, and by means of shrewd stage-management intermpts and then reforms the natural course of events. When occasion demands he will people his domain with an imaginary garrison, or act the part of his aide. And so, after subjeoting the mutineers to a harrowing assault course, he exalts, perhaps consoiously, in his Prospero-like roles

We could hear them call to one another in a most lamentable Manner, telling one another, they were gotten into an inchanted Island; that either there were Inhabitants in it, and they should all be murther'd, or else there were Devils and Spirits in it, and they should all be carry'd away, and devour'd. (p.266) 
69.

But to Crusoe himself, after all, the island has appeared in much the same light. It is because he continues to have a hard time keeping his sense of order intact that the moral draw from this phase of his life remains central (p.I59). There is little to fear, other than fear itself. 
Defoe's Wildernese:

The image of Africa in Captain Singleton

Over a hundred and fifty years before Verney Cameron made the first recorded journey through equatorial Africa a similar crossing, from east coast to west, was undertaken by Defoe. The passage in question occupies about one-third of Captain Singleton (I720) where it comes by way of deviation in a narrative largely given over to the hero's piracies. Everyone agrees, however, that it is the continental slog that supplies the liveliest part of Singleton's adventures, and a recent critic has referred to his trip as "the most remarkable and imaginative trek in the whole history of the eighteenth-century English novel". I In fact the episode holds historical interest of a more direct kind, for it represents not only one of the earliest fictional treatments of Africa but probably the most important of its period. Of course, though sharply lit in places, Defoe's picture of a continent is for the most part vague. Its prevailing tonalities are correspondingly sombre.

At the start of his venture Singleton sets the scene with a few slashing strokess

We were now landed upon the continent of Africa, the most desolate, desart, and unhospitable Country in the World, even Greenland and Nova Zembla it self not excepted. (p.58)

While superlatives continue to betray the mythioal basis of his vision he proceeds to people his ultimate wilderness with tribes "barbarous and brutish to the last Degree" (p.58). Apart from materials gathered from his broad reading in travel literature Defoe relied on a blend 
of conjecture and hearsay in projecting his image of Africa. Rather like Swift's enthusiastic geographers who embellish the blank spaces on their maps with "savage-pictures", he seems to have recognized that he was free to invent so long as he steered clear of welldocumented features such as famous rivers or the settlements on either seaboard, for the route devised for Singleton's party, as Scrimgeour has pointed out, keeps scrupulously to regions that were almost wholly uncharted. ${ }^{3}$ operating, again, in the twilight zone between fact and fiction Defoe appears to have allowed himself some degree of latitude in his adaptation of sources. When, for example, he has his east-coast tribe of sunworshippers mistake the explorers for beings "who came from the Sun, and that could kill them all, and make them alive again" (p.83), he almost certainly draws on a passage from Hakluyt describing an enoounter with American Indians. ${ }^{4}$ Defoe fabricated and transplanted wholesale but at the other extreme (and mainly where mercantile issues were at stake) he fell back on firsthand report. He was later to name his informant as a certain Mr Freeman and to identify him with the character of the Englishman-gone-bush who puts in an appearance towards the close of Singleton's journey. On the history of this mysterious and even Kurtz-like figure, a profile of whose activities emerges from the records of the Royal African Company, this chapter will throw some fresh light. But the chief aim is to examine the assumptions and energies which underlay Defoe's presentation of the scarcely inked continent; and the first step in this direction is to place the expeditionary interlude in its context. 
Singleton's trek is an undoubted asset, but severel oritios heve seen in it the symptom of a digressive tendency that saps the strength of the text as a whole. "At the transitional points", John R. Moore remarks of the novel, "the story veers uncertainly, like a sailing vessel about to change its course" - to which he adds, "when Defoe was uncertain what story he meant to tell, he could make sad work of $1 t^{\prime} .5$ Perhaps the Afrioan journey contributes to the impression of plecemeal construction mainly because it comes after Singleton's piratioal leanings have been advertised (pp.29-3I,36). Clumsy story-telling always deserves a frown, but there is a good case for claiming that Captain Singleton represents one of the more intellectually coherent of comparable narratives. Episodes that appear random at first sight fall into place once we credit Defoe with thematic aims and recognize that he is concerned, primarily, with the question of what constitutes the primitive state, and by way of corollary, with what constitutes redemption from it.

The phrase is one that Singleton applies to himself when facing starvation in Portugal during his early teens." I being then almost reduced to my primitive State", he writes and immediately describes his first taste of foreign parts, "I knew no body, and could not speak a Word of their Language" (p.4). Defoe specialized in the lives of the abandoned, but nowhere does he stress the debilitating effects of loss with quite such force as in his treatment of Singleton's calamitous childhood. Although much of his hero's osreer was modelled on that of Captain Avery, Defoe al together made up, as Riohetti has noted, the upbringing that leaves his young tyro "not so much outside society as outside any 
coherent being of his own". Sold for twelve shillings at the age of two, Singleton, like Koll Flanders, ts passed from hand to hand, "dragged about" as he puts it, and effectively orphaned many times over. After his good, Gipsy foster-mother happens "in Process of Time to be hang'd" $(p .2)$ he is taken in by the Parish until his right to such provision is successfully contested. Moll is taught the acoomplishments of a lady but, apart from his brief spell under the beadle, Singleton comes by no education whatever. All be recalls of his schooling is patronage of the sort recorded later by Blake in "The Chimney Sweeper": "the Minister of the Parish used to talk to me to be a good Boy; and that tho' I was but a poor Boy, if I minded my Book, and served God, I might make a good Man" (p.3). In consequence, al though he grows up at the heart of a Christian nation Singleton develops into the very type of an indigenous beathen. When called a heretic by the Lieutenant of his third ship, the Portuguese carrack, he is saved the trouble of feigning bewilderment, "I knew nothing about Religion, neither Protestant from Papist, or either of them from a Mahometan" (p.9). With some alarm he imagines himself arraigned before the Inquisition lacking the knowledge even to supply a yes in the right places, a daydream that enlivens his frequent olaim to being "a Boy entirely ignorant of Religion" ( .9$)$. So well known is he as a pagan on board the Portuguese boat that the orew allow him to be "no Turk" only after he has stripped and submitted to eramination (p.IO).

The ground of Singleton's Identity is intransigently physical and Defoe might have underlined his oultural estrangenent still further 
had he not required a literate narrator. As it is, he frequently reminds us that his pirate hero feels no particular allegiance to the country of his birth. It is true, almast invariably, of stories set in exotic places that a desire for homecoming spells out homage to the mother culture. In Heart of Darkness Marlow triumphs over Kurtz when he coaxes him into the steamer that heads downriver. In Lord of the Flies characters take sides over the priority to be given to hunting or keeping alight the beacon. Or, again, in Herzog's Aguirre political and cultural severance is implied by the decision to follow the waterway into the hinterland. Defoe adapts this feature of the travel story to his own use when he shows that Singleton is never less at home than when he gets there. After his return from Africa he dwindles like his stock until a pretext for fresh adventure suggests itself. When he comes home for good he is forced - as the price of his villaing - to keep himself permanently disguiseds with the help of a moustache and some strange clothes he passes for Greek but not a single word of English dare he risk in company. In short, Singleton remains an alien; but in one respect his case proves exceptional. While never an Englishman in England, he at no point discloses a preference for settling elsewhere. When he comes across countryside of exceptional resource in Madagascar he can neither bring himself to decide whether to stay or go. The ohoice is left to his Portuguese companions who determine to head for Europe, and he dismisses his dilemma with a shrugs "I had no home, and all the Horld was alike to me" (p.43). Defoe points, by these means, to the vecant and listless character that dictates Singleton's footloose career. 
It is conventional in the adventure story for the hero to experience a sense of release on venturing beyond the bounds of polity. In Singleton's case this moment oomes when, as a punishment for muting, be and a group of the Portuguese crer are set down on the coast of Madagascar and left there to fend for themselves. But, once again, the personality of the hero prescribes a deviation, for - as Defoe immediately proceeds to show - his castaway already belongs to the far side of the border between wildness and civility. "I was now to enter", Singleton remarks of his newfound freodom, "a Part of independent Life"; but then he observes,

a thing $I$ was indeed very ill prepared to manage; for I was perfectly loose and dissolute in my Behaviour, bold and wicked while I was under Governwent, and nox perfectly unfit to be trusted with Liberty.

Sinoe no institution has helped him surmount the "State of Original Wickedness" into which he was born, Singleton is devoid of "all Sense of Honesty or Religion" ( $p .8$ ), and thus already a part of the lawlessness whioh awaits him beyond the frontier.

Defoe brings a range of devices to bear in order to regfster the depth of his hero's depravity. He introduces, for example, a series of unsavoury racial stereotypes which he puts to use as a jardstick. After classing the Portuguese as the lowest ranking nation in Christendon

a Nation the most perfidious and the most debauoh'd, the nost insolent and oruel, of any that pretend to oall themselves Christians, in the World 
he has his English renegade admit, "I was exactly fitted for their Society" (p.7). It comes as no surprise to find that Singleton rates the people of Madagascar a great deal worse. Yet even while supposing them to be cannibals he again conceder kinsh1p, this time with a wry joke at the expense of himself and his mates:

I told him I was not so afraid of that, as I was of starving for want of Victuals; and as for the Inhabitants being Cannibals, I believed re should be more likely to eat them, than they us, if we could but get at them.

Homeless Singleton may be, but on leaving Europe he can at least enjoy the status of a heathen among heathens, and in his element he remains so long as his adventures last. They come to an end when he repents which he does, of course, though with a perfunctoriness scarcely equalled in Defoe. It is significant that his first inkling of grace should take the form of heartfelt thanks that he was not born a pagan ( 0.74$)$.

Though the episodes of the novel are diverse they respond to a simple pattern. For, whatever his part, Singleton continues to live, as his name suggests, the life of an outsider. So it is that after exchanging the existence of outcast for oastavay, he opts for the most anti-sooial of profeseions by turning pirate. Of all Defoe's creations Singleton is by a long way the most appalling. He boasts his lack of compassion, revels in violence, and has even to be reminded that his business on the high seas is bounty rather than bloodshed (p.266). But by including elements of buffoonery Defoe frequently distracts the reader from the moral ugliness of his hero. Singleton proves disarming 
when he passes himself off as "very dull" (p.4), or conveys his dependenoe on the suavely shrewd Quaker William with a humour that looks forward to Jeeves and Berties "I would fain have had Friend William's Advice ... but he always put it off with some Quaking Quibble" eto. (p.I88). The jokes are strategio. In his pirate Defoe found an image of the natural man, and the oomic palliatives allow him to oharge his portrayal with all the voracity he had ascribed to the instinctual life in the opening lines of Jure Divino:

Nature has left this Tinoture in the Blood, That all Men would be Tyrants if they cou'ds If they forbear their Neighbours to devour, 'Tis not for want of Will, but want of Power. ${ }^{7}$

Where constraint wears thin nature breaks out, as in the life of an Avery or Singleton. If it was from the materials of the rogue tale that Defoe refined his idea of the "primitive state", he certainly took care to extend the theme when it came to his choice of setting.

A close link between alien cultures and the untutored soul was taken for granted during the Enlightenment. Even the sceptioal Hobbes, who bypassed all recourse to Eden or the Fall, had hypostatized his theory of the natural state by referring to the existence of primitive peoples instead. Only very shortly after delivering his famous account of man's native oondition - a life, "solitary, poor, nasty, brutish, and short" does be point to "many plaoes, where they live so now", oiting in particular the "savage people" of Amerioa whom he supposes to subsist with "no government at all". 8 Iisting a range of oultural achievements elsewhere, he goes on to asks "all which supposed away, what do ve differ 
from the wildest of the Indians?"." Whatever might be said of America in this context was all the more applicable to Africa. Commenting on the European view of the Dark Continent during this period, van Wyk Smith notes the recurrence of disutopic paradigms, and quotes a passage from the Atlas Geographus (I7II-I7) by way of samples

The Caffres are a sort of libertines, who inbabit from Mozambique to the Cape of Good Hope, live promiscuously without ceremonies, like our Adamites, and wallow in lust and sensuality ... They live by war and rapine, and feed on the flesh of their enemies and friends, using their skulls for drinking cups ... In short ... they are the most nasty and brutish of all reasonable oreatures. IO

The casual borrowings from Hobbes in the last clause show just how instinotive was the reflex to embody - in the portrayal of a distant people - ideas deriving from some essentially abstract notion of man's natural state. Although a little less easy to detect, the same principle is at work in the descriptive gloss to Alrica supplied by Defoe for the Atlas Maritimus (I728). Blacks are repeatedly presented here as "brutal" and "savage", terms that are used interchangeably with "wild" and "unpolish'd"; and the continent itself identified with nature since all that it generates in the way of produce is "without the Helps of Art, without Cultivation or Manufacture". II Although a atrong abhorrence of the primitive is common to many traditions Hobbes, once again, appears to be the presiding influence. Defoe know very well that there was agrioulture in Afrioa but, almost as a nerrous tic it seems, he olings to the guidelines laid down by the philosopher in his famous defintion of the natural state: "In such oondition, there is no place for industry; because the fruit thereof is uncertains and consequently no oulture of 
the earth; no navigation, nor use of the commodities that may be imported by sea ... no arts". I2

Over his long and voluble career Defoe held conflioting views about Leviathan, but there is no doubt that his debt to it is an important one. I3 If Hobbes's view of the natural state was darker than he was willing at times to accept, he could rest content, at least, with the idea that it refleoted the condition of man during the nadir of his history, the period after the Flood. I4 When Robinson Crusoe ponders human nature, it is to the Creation and Fall that he turns his thoughts: in his state of grace he sees the island as a "planted garden"; and the footprint later impresses an understanding of original sin. I5 when Singleton, on the other hand, is confronted with the "vast howling Wilderness" ( 0.96 ) that Defoe situates at the heart of Africa - a region which he oupposes entirely unvisited - his imagination is carried forward to the "End of Time", and such reflections as he makes on the origin of his surroundings prove deeply ambivalent. The Creator plaoed fish in the great central lake, "for to be sure no human Hands ever put any in there, or pulled any out before" (p.IOT), but the waste land also contains oreatures that appear to emanate from the Devil - vitness the monster with "a hellish, ugly, deformed Look and Voice", a snake-like dragon of whioh Singleton remarks, "we did not know what Business Satan could have there, where there were no People" (p.I29). Apart from these fow uneasy peeps at genesis, time in Africa begins for Defoe with the Flood. If he wishes to stress the emptiness of the inner desert he writes nnever Man set his Foot [there] since the Sons of Noah spread themselves over the Pace of the whole Earth" (p.I29). And when he insists on the untamed 
ferocity of the animals his party meets, he resorts again to the same image of devastations

For as I firmly believe, that never Man, nor a Body of Men, passed this Desart since the Flood, so I believe there is not the like Collection of fierce, ravenous, and devouring Creatures in the World.

Defoe presents the face of Africa as struck in a scowl that reflects, forever, the wrath of God. In other of his writings he could entertain the idea of a primitive innocence corrupted by exposure to the West. I6 When it came to Africa, however, his view was such as to imply that no change could be a ohange for the worse.

Captain Singleton is the darkest of Defoe's fictions and perhaps for this reason the one in which his reliance on Hobbes is most pronounced. In Leviathan man opts out of his natural state by renouncing his "right of nature" - the power be has to fulfil his wants - and contracting instead for the rule of law. Contract enables the exchange of strife for peace; and it is precisely this process of transformation that Defoe examines at a variety of levels in Captain Singleton. He begins with the castaways who, although they represent a "mutinous Rabble" ( $p .22)$, sink their individual differenoes in a publio oonstitution which they recognize to be indispensable to survival (p.25). Natural right is ourtailed still further when they agree to pool their gold finds so as to guard againgt conflict ( $p . I 56)$; and the corporate nature of their enterprise directs that even the shelter they build against the raing season be designed to a strictly commanal plan (p.I20). The growth of sooial oonsoiousness among Singleton's troop of desperadoes goes some 
way to dramatizing an idea that Defoe had voiced in his Review:

if twenty Men born in the dark, and that had never known Men or thinge, were set on Shore in an Island, where they had no body to imitate, and nothing to do but to live; the first thing they would apply to by the Light of Nature after Food, would be to settle Govermment among them. I7

The innate desire for social order is a basio tenet of Leviathan; and what Hobbes had prescribed as the most fundamental article of natural law - the right to defend peace, even if necessary with force - is repeatedly invoked by Singleton as the Law of Arms and put into effect the moment his party encounter an African tribe. ${ }^{I 8}$ The first spear to be thrown on this ocoasion provides the pretext (long-awaited) for closing ranks and opening fires hostilities end only once sufficient prisoners are seized to make up a complement of porters. Hobbes had acclaimed as universal the principle that obligations incurred in wartime were binding, but Singleton is reluctant to attribute a grasp of natural law to his oaptives, whom he keeps shackled on the grounds that they are "fierce, revengeful and treacherous":

for which Beason we were sure, that we should have no Service from them but that of meer Slaves, no Subjection that would continue any longer than the Fear of us was upon them, nor any Labour but by violence. $(p .66)^{\text {I9 }}$

Here, however, Defoe seems to question Singleton's judgement. The tribe's chief, dubbed the"Black Prince", earns the status of noble savage by stepping into the role of mediator and showing his appreciation of contract: he made Signs to me, that if I would let one of the Prisoners go 
to his Tom, he should bring Provisions, and should bring some Beasts to carry our Baggage. I seemed loath to trust him, and supposing that he would run away, he made great Signs of Fidelity, and with his own Hands tied a Rope about his Neck, offering me one End of it, intimating, that I should hang him, if the Men did not come again.

With elaborate ceremony the porters then swear to be faithful in exchange for proteotion and food from the European party, but only after the first leg of the journey is over does Singleton win enough oonfidence in them to abandon his makeshift system of handouffing. The tribesmen never fail to keep their part in the bargain, allowing Defoe to score a small point against subjugation - a point later to be amplified in the plea for clemency that Quaker William makes on behalf of the mutineer slaves found aboard a drifting vessel:

I had much ado to keep my Men from cutting them all in Pieces. But William, with many Perswasions prevailed upon them, by telling of them, that it was nothing but what; if they were in the Negroes Condition, they would do, if they could; and that the Negroes had really the highest Injustice done them, to be sold for Slaves whout their Consent; and that the Law of Nature dictated it to them; that they ought not to kill them, and that it would be wilful Murder to do it. (p.I9I, my italios)

Here, once again, Defoe falls back on Hobbes who had proposed, as a rule of thumb for determining natural law, the maxim: "Do not that to another, which thou wouldest not have done to thyself". 20

Defoe celebrates the fruits of social contract at every available turn. He makes it cloar that the expedition ores its sucoess to a code that reduoes the "Hazard of any Differenoe" among its Individual members 
(pp.II5-6); and the same benefit conspiououely derives from the various covenants formed with looal peoples since by their means conflict is, again, frequently averted. When it comes, however, to presenting relations among the blacks themselves Defoe falters. Typioally, his first reaction is to conjure up hordes of savages living in the state of nature. Writing in this vein he is free with the Hobbesian adjective "brutish" (pp.25,58); and correspondingly sceptical of anj capaoity for pacific, social existence: "a Parcel of Creatures", Singleton exclaims of the Madagascans, "scarce human, or capable of being made soolable on any Account whatsoever" (p.26). Observations of this kind are tossed off throughout, but whenever Defoe settles to description a different picture emerges. Far from revealing wild abandon bis tribesmen incline, during these spells, to ant-like servility, and with the exoeption of the Black Prince, whose negritude is always on the point of washing off, all trace of individuality dissolves in rigid marshalling. What sustains this presentation is the dream of an ideal labour force, and so long as it prevails the narrator's fear and disdain are kept in cheok. The motif of treachery recurs, howerer, with the account of a tribe that stages an attack during a truoe (pp.9I-3). But if Defoe seriously intended here to piok up the earlier hint that savages are beyond the reach of law, he fails, for his repeated observations of indigenous tokens of peace - oaths to the sun, poles driven into the ground - imply a oulture in steady possession of contract. Contradictions multiply and every reading leads to a dead end, for, although quite ready to assume that to live beyond Western polity was to live whout sooisl order, Defoe found himgelf baffled in his attempt to imagine that contradiotory thing, a tribe of 
tigors. When it oame to substantiating his notion of the natural state his automatic recourse was, in any oase, to individual Europeans.

Hobbes had noted the essentially egalitarian impulse underlying his philosophy, and in so far as Defoe allows Africa to enter into his celebration of social contract, he closes the gap between the tribesmen and his explorers: the observance of natural law limns out, slowly but surely, the features of a common humanity. He reverts, however, to his earlier insiatence on the remoteness of primitive peoples, with the appearance of the forlorn"White Man"in the depths of the continent. The inset story of this lonely figure partly recapitulates and partly reverses that of Singleton. He presents, in the first place, another example of the outcast, for it is after his unfair dismissal from the Royal African Company that he sets up as a freelance trader in the region of Sierra Leone, only to be kidnapped by a series of tribes until he ends three hundred miles inland "entirely at the Mercy of the Negroes"(pp.I5I-2). But whereas Singleton progressively triumphs over his disabilities, submitting to the "Artioles" of his commune, apprentioing himself both to the learned gunner ("Knowledge was the first step to Preferment", p.69) and to the olever cutler (pointedly referred to as the "Artificer" or "Artist"), the fortunes of his oompatriot are dombill all the way.

To his inquiry into what happens to a man deprived of religious instruotion, and to his probing into the lives of those born outside Western societs Defoe now adds, by way of rider, an investigation into what happens to the man stripped of relation to his oulture; and his answer 
could not be less equirooal. There is a primitivism for which the bronzed body in far-away places serves as an outrard sign; but the Englishman's physique, hairy and horrible from exposure, onunciates quite another themes

He was a middlemaged Man, not above 37 or 38 , tho' his Beard was grown exceeding long, and the Hair of his Head and face strangely covered him to the middle of his Back and Breast, he was white, and his Skin very fine, tho' discoloured, and in some Places blistered and covered with a brown blackish Substance, scurfy, scaly, and hard which was the Effect of the scorching Heat of the Sun; he was stark naked, and had been so, as he told us, upwards of two Years.

To fill in the rest of the picture Defoe requires only a few broad strokes. Far from debating the pros and cons of a return to society the White Man speaks of his Iife among the tribesmen (who appear to cater to his every need) as "the most wretched Condition that ever Man was reduced to" (p.I49). And when asked why he takes no trouble either to clothe or to arm himself he replies, "that to him who had so often wish'd for Death, Life was not worth defending" (p.I52). His rescue brings on such transports of joy that he trembles for days on the verge of tears and piously refers to the explorer's arrival as his Deliverance. With a haircut and shave his rehabilitation is under way, and with the gift of an outfit his self-esteem evidently rekindles, for he is inspired to fashion himself ("most artificially", p.I5I) a leopard-skin oap.

In the section on Africa in his Atlas Maritimus (I728), a work started three jears after Captain Singleton, Defoe returns to his acoount of the Englishman-turned-native, adding a fer fresh dotails ("yellow hair'd, 
almost red") and some lurid adjectives ("despioable", "scrophulous", "frightful") before concluding:

In a word, not the Fable of Orson the Brother of Valentine, could represent a wild Man more to the purpose, than Mr Freeman appear'd to them, (for that was his Name). 2

Defoe's facts are seldom free of fiction, but even if we discount as legend "the Journey of the Thirteen Portuguese before they met with [him]" there is no doubt as to the identity of the Wild Man. ${ }^{\prime \prime}$ John Freeman's dismissal and recrimination for arbitrary conduct is mentioned in a history of the Royal African Company by K.G. Devies; ${ }^{23}$ and the archives of this infamous institution contain not only the correspondence over his period of service at Sherbro (I702-06) but several reports of subsequent adventure up to his death in Sierra Leone five years later. Defoe's aoquaintance with Freeman may well date from the spell the officer spent in London, defending his dereliction of property at Sherbro when under attack by the French, for the account given in Captain Singleton is more flattering than was the judgement of his governors. But, in any case, since Defoe aoted as a publicist for the Company, held large shares in it, and was on olose terms with one of its most powerful direotors, he would certainly have kept abreast of news, and in all probability read the letters coming in from Africa. 24

In his fiotional portrait of the European-gone-bush it is on the literal aspects of vildness that Defoe insists. What he really piotures, a. bis later reference to the tale of Valentine and Orson makes olear, is the classioal case of an enfant saurage fostered by beasts - a man 
with coarsened skin, and hair grown to the waist. ${ }^{25}$ But apart from his appearance and thoroughly depressed state of mind the English outcast remains in other respects the perfect gentlemans

We found his Behaviour the most courteous and endearing I ever saw in any Man whatever, and most evident Tokens of a mannerly well-bred Person, appeared in all things he did or said; and our People were exceedingly taken with him. He was a Scholar, and a Mathematician; be could not speak Portuguese indeed, but he spoke Latin to our Surgeon, French to another of our Men, and Italian to a Third.

The magnetism and distinetion are reminiscent of Kurtz but there is never a word of unsound methods. Yet when we turn to Defoe's model we find that the evidence of wildness is all on the moral plane.

Talo-telling seems to have been a perennial occupation among colonial offictals in Africa, and there is some reason to take the charges that led to Freeman's dislodgement as manager at Sherbro with a pinch of salt. Quite apart, however, from the complaints that he abandoned an island to the French or often cursed the Company, roving "he oame not over to defend or Fight for [its] Interest", the testimong to Freeman's misconduct certainly mounts up. At different times he is accused of embezzling diet-money by keeping his men on short commons, of dealing against prescription - with freelance traders or the Dutoh, of underhand hoarding and of downright theft. More telling perhaps, a junior member seconded to his station instantly returned, alluding darkly to the manager's "unlawful rays". After his dismissal and year in London, Freeman resumed trade at Sherbro in opposition to the Crom, but desplte his boast that 


\section{8.}

no-one enjoyed such an "Interest among the Natives as himself", blurted out in the course of a pathetic appeal for rememployment, he seems to have met with little success. There can be no reason to doubt the sober asides that now sparsely punctuate the flow of company business. We hear of "Mr Freeman and his gang" preparing to convert ships, or "reflecting scandalously" on their rivals in an attempt to win over former colleagues. One defeots; but Freeman is forced to shift the scene of his ambitions:

He dares not be seen in Sherbro River - be is gone to Serraleon and builds houses tho' Ready dayly to be murdered by ye Country people for his base behaviour.

No details are supplied, but there is mention later of Freeman's setting fire to a tribal settlement. The rest of his life is covered in three sentences, each separated by over a year:

Mr Freeman has lost his interest in the river...

Mr Freeman has several small vessel going to decay ...

Mr Freeman died ye 3rd of December.

He was barely survived by his chief accuser who succeeded him at Sherbro. His name does not appear among the corporation's dead. 26

Although a rascal in the eyes of the Company there seems, in retrospect, little to choose between Freeman as truant and officer. Slavery was the chief business at Sherbro, and in the letter of appointment setting forth the manager's duties, detailed instruotions for the branding of Negroes shortly follow on the rules for morming prayers. 27 In addition to seleoting and assigning slaves, a task that involved him in winning the 
favour of local chiefs, Freeman was expected to explore openings for the more orthodox channels of trade. It was with this aim that he led an expedition for ivory far into the interior during his managerial days; and it is almost certainly the report of this trip that Defoe retails in his Atlas (he cites Freeman as his source) in a passage that almost exsctly parallels one of the most vivid in Captain Singleton. 28 Though the fictional version represents one of the few occasions on which Singleton concentrates on his surroundings, its chief interest lies in what it reveals of Defoe's self-induced blindness. The paragraph opens with an evocation of a vast, desolate plain, strewn with elephant bones - the scene that greets the party as they approach the heart of the continent. With great skill Defoe plags off time against space, small against ever larger units so as to impart a suggestion of the sublimes

For a Day's Journey before we came to this Lake, and all the three Days we were passing by it, and for six or seven Days March after it, the Ground was scattered with Elephants Teeth, in such a Number, as is incredible; and as some of them may have lain there for some Hundreds of Years, so seeing the Substance of them scarce ever decayes, they may lye there for ought I know to the End of Time.

(p.I06)

It is a thrilling moment and a poignant one, for the diminishing perspective intensifies the frailty of Singleton and his men, who on entering the central desert have seen before them "nothing but present Death" ( 0.97$)$. But as the paragraph gathers pace the exactly felt atmosphere of a setting and juncture gradually gields to an interest in exploitable value, an interest, that in view of the explorer's situation has, moreover, no dramatio dividend to offers 
As to Number, I question not but there are enough to load a thousand Sail of the biggest Ships in the world, by which I may be understood to mean, that the Quentity is not to be conceived of.

The same form of words occurs in the Atlas, but if the "thousand ships" still partly function as an index of wonder, the effect proves fleeting for in the following clause Defoe is already parcelling up the desert,

as they lasted in View for above elghty Miles Travelling so they might continue as far to the right Hand, and to the left as far (p.IO6).

And by the next sentence be is well launched in the gas of a sworn appraiser,

this was partioularly remarkable to me, that I observed the whole Scull was as good Ivory as the Teeth, and I believe all together weighed at least 600 Weight.

It is symptomatic of Defoe's outlook that he should in the course of a single page reduce the field of vision from infinity to little more than a grain of sand. The habit of mind that regularly akes the word "good" a synonym for "valuable" betrays an allegiance to the mercantilism so widespread during his time. Defoe was unquestionably a part of that ethos which more august spirits determined to shun. 29

"To tell the Truth", the narrator in A New Voyage Round the World (I725) remarks of his more learned crell, "our Doctors themselves ... were so taken up in the Traffick for Gold; that they had no Leisure to think of any Thing else." 30 Though the voyage is meant to be exploratory this 
later text is blighted by Defoe's Midas-like touchs all discoveries must tend the narrator urges "to the Advantage of Trade"; and the success of the venture itself is gauged in terms of profit. $3 I$ The idée fixe enters Captain Singleton but fortunately in less programmatic guise. Part of the intention here, Peter Earle shrewdly observes, is "to demonstrate to readers the possibilities and gains to be had from Africa"; this does not deter Defoe from making over half his book to piracy, never an encouraging subject to traders, or from developing his central conoern with the primitive state. ${ }^{32}$ Indeed, he attempts to clamp his obsession to the thematic chassis of his runaway tale. Trade is given a redemptive status equivalent to that of education, or social contract. It has, as the White Man explains, the power to reclaim wilderness, within or without:

he had been all Night revolving in his Mind what he and we all might do to make our selves some Amends for all our Sorrows; and first he said, he was to let me know, that we were just then in one of the richest Parts of the World, tho' it was really otherwise, but a desolate, disconsolate wilderness; for says he, there's not a River here but runs Gold, not a Desart but without Plowing bears a Crop of Ivory.

By smuggling in the notion of cultivation Defoe elevates scratch-mining to a remedial art; the aura surrounding the passage derives otherwise from Isaiah's Messianio paeans "The wilderness and the solitary place shall be glad for them; and the desert shall rejoice, and blossom as the rose" (35:I). Proof of the potency of the White Man's tonio is given by his subsequent recovery from despair. Over his two years of wishing for death bo has lost all interest in gold, as bo bas in 
weapons ( $p$.I52,I55): his renewed acquisitiveness comes accordingly as the mark of returning health. For his avidity he pays later with his life, since it is after losing the fortune he has amassed from mining that he dies of a broken heart, but here again Defoe averts his gaze, deliberately overlooking the opportunity for a cautionary tale against greed: "Life", as he wrote elsewhere, "should be progressive and increasing." 33

Trade was for Defoe the divinity of a secular religion, and he apostrophized it variously as the patron of arts, mother of industry and genius of learning. 34 His prose often takes on the declaratory quality of a psalm when he turns to its celebrations

Trade carries the very soil away, and transposes the World in Parts; removing Mountains, and carrying them over the Sea ... Their Rivers are throng'd with Shipping like a Wood; their Naval Stores are inexhaustible. 35

It is not uncommon to find him applying the same figure to spiritual and commercial development. In his General History of Discoveries he advances the idea that riches were planted in distant places to act as a ohallenge to man after the Flood:

The World was to him like a rough Diamond, that has its intrinsic Value in itselfs but the Outside conoeal 'd the Inside, and it was for him to polish it that its lustre might appear. 36

In the traot he wrote on Peter the wild boy, paraded in London during I726, he refleots: 
The Soul is plac'd in the Body like a rough Diamond, which requires the Wheel and $\mathrm{Knife}$, and all the other Arts of the Cutter, to shape it, and polish it, and bring it to shew the perfect Water of a true Brilliant. 37

As well as to Mammon, Defoe looked for salvation to the Puritan God of his upbringing; and in Captain Singleton where trade vies with Quaker William as the chief redemptive influence, his two religions are at war. Over the issue of slavery conflict comes to head. William condemns the institution when he boards the slave-ship: Singleton and he then pocket a huge sum from the sale of slaves. Defoe inberited the Dissenter's tender conscience towards servitude and in an early satire, The Reformation of Manners, hit on a memorable phrase when he attacked those who "Barter Baubles for the Souls of Men". ${ }^{38}$ But he knew also that the transatlantic traffic in slaves provided the base-line of all international trade, and the recognition made him alter bis tune. In the course of a lucid exposition of the triangular route be rejoices in the trinkets of exchange:

Whatever can be said for a Trade, that is the Essence of our Colonies - The Support of our Sugar and Tobacco Norks, that brings much Home, and carries little out; that Exports nothing but what we can spare, and brings Home nothing but what we cannot be without - That sets our Poor to Work, for Manufactures, Employs our Shipping, and extends our Dominions; That carries out our Woollen to Africa, carries Slaves to Amerioa; That barters Gold for Glass-Beads, and the Riches of Africa, for the Baubles of Europe, way be said for this Trade. 39

It is no accident that Robinson Grusoe's adventures follow the sequence of the main route of trader he sails down to Guinea as a merohant; crosses 
the ocean in a Portuguese slaver turns planter in Brazil until, inspired by his need for cheap labour, he determines to undercut the prices fired by esiento and sets himself up, like Mr Freeman, as a freelance trafficker. The ship in which he comes to grief has been specially fitted out for slaves. But if it was the triangular route that stirred Defoe's creative impulse it was to prove a dangerous stamping-ground for his imagination. Although bitterly resenting his own enslavement, Crusoe ascribes his shiprreck - which be reads as a punishment - exclusively to the bourgeois vice of imprudence, and never reflects, after his repentance, on his shady dealings in the trade. The omission was glaring even by the standards of contemporary readers, one of whom complained:
having fix'd his Plantation ... [Crusoe] sets out upon new Adventures ... bound to the coast of Guinea to buy Slaves ... yet he neither then nor afterwards found any check of Conscience in that infamous Trade of buying and selling of Men for Slaves; else one would have expected him to have attributed his Shipwreck to this very Cause. 40

Perhaps Defoe's unconscious mind was active where his eyes were sealed, but of his insensibility there can be no doubt. His Essay upon Projects includes a scheme for the importation of two hundred slaves; and in the pamphlet he wrote for the Royel Afrioan Company he argues against the freelance trade on the grounds that a monopoly would reduce the price of each and every head. 4 I The pursuit of wealth had hardened his gaze. It was a blind spot at the centre of his vision that turned the heart of Africa into Singleton's unpeopled waste. 
Melville's Happy Valley:

Typee and its literary context

Melville is among those great American writers who, sensing an absence of rhetorical convention, consciously set out to find and claim a literary inheritance of their own. In consequence Typee, his first book, though written during the eighteen-forties, is founded so firmly in traditions of the previous century that it revives a series of earlier texts dealing with exploration, and goes some way, indeed, to unfolding a critical record of the main landmarks in related literature before the appearance of Moby Dick (I85I). Much less of a stylistic mosaic than the later masterpiece, Typee (I846) preserves the even surfaces of a realistic, first-person narrative and reads like a more polished version of Robinson Crusoe (I7 I9), a text to which it reveals a deep and often acknowledged debt. I In place of a lunging interior voyage in the track of a slippery whale, what we are given, under cover of Tommo's story, is a rationally conducted commentary on the nature of man. But the homogeneity is less real than apparent for the novel straddles traditions that are essentially disjunct. It is symptomatic that we should find in the course of a few pages a reference to Rousseau's Confessions (I78I) rubbing shoulders with an allusion to Rasselas (I759) ( pp.I79,I83). While Rousseau appears paramount in matters of ideology (the word is wholly appropriate) Melville shows himself equally versed in the procedures of Augustan satire: switches of perspective challenge the prevailing optimism, and the 
narrator's flow of assimilative energy is perplexed from time to time by a darker tone. ${ }^{2}$ Modes of address vary too. When Tommo is overtaken by one of his "inquiring, scientific moods" ( $p .245)$ narrative is suspended to allow for the inolusion of essay material, mainly of an ethnographic kind. Story-telling alternates with this more sombre recounting of fact.

Typee is, indeed, a closely autobiographical work. After a gruelling six months aboard the Acushnet, Melville and a friend jumped ship at Nukahiva, one of the Marquesas islands, and made their way inland until they found themselves in the valley of the Taipis, a virtually unvisited tribe notorious for cannibalism. The treatment they received at their hands was hospitable,but after ten days the friend went off in search of medical aid for his companion's swollen leg, never to return; and Melville made his escape little over a fortnight later. To these events the narrative is faithful, and while Melville certainly extended the lapse of time in his story and appears to have exaggerated the primitiveness of the community he was practically the first European to penetrate, he was keen to stress the documentary aspect of his fiction; and accordingly sketched in the geography and historical background to his venture as well as vouching in a preface for its truth. ${ }^{3}$ When Typee first appeared it was as part of John Murray's"Home and Colonial Library", a series given over to non-fiction which already boasted Darwin's Voyage of the "Beagle" (I839). 
It is al together consistent, then, that Melville should call attention in Typee to his activity as an explorer. He relates his excursion to the early voyages of Mendaña and Quirós and, more frequently, to the experiences of Cook who had put in at the Marquesas long enough to affirm that its inhabitants were the finest people he had encountered in the South Seas (pp.37-8, $44,244,310) .^{4}$ Here again Melville places himself at the apex of an eighteenth-century tradition, for it was the sixties and seventies that saw not only the reopening of the Pacific to Western eyes but the rise of a scientific mode of geophysical and ethnographic enquiry which, if not al together disinterested, presented at least a marked contrast to the raw mercantilism of the preceding era. Owing largely to European rivalry over the consolidation of colonial territory, the first half of the eighteenth century had, in any case, amounted to a relatively uneventful period as far as exploration was concerned. History could offer little to compete with Captain Singleton's adventures or Crusoe's peregrinations in the Gobi desert, and readers in search of the exotic had for the most part to turn to collections of earlier voyages when they had done with Defoe. But the gap between fiction and history which narrowed as the century advanced was effectively bridged by Melville who, when it came to writing novels of exploration, had his own experience on which to rely. He had behind him, also, the example of a new kind of travelogue, relatively organized, more discursive and minute. In Typee the influence of such reading is clear from 
the frequent digressions on topics such as the preparation of tappa or poee-poee; and by the time of Moby Dick the informative, scientific impulse had assumed such prominence as to vie with narrative. But Melville's inset descriptions, even at their least successful, are quite unlike Defoe's fussy shows of fact. Perhaps it was because his stories were substantially true that Melville could afford to be so much freer in imparting fictive shape.

Literary influence that is crucial seldom declares itself in a congruency of plots. Typee shares with Robinson Crusoe a three-stage narrative - a movement from separation through adventure to return, but Melville's more significant debt is to Crusoe's Janus-faced island. The appropriation of this motif is telling for it points to a marked divergence of concern. In Robinson Crusoe the hero's shifting states of mind are more important than they are in Typee. Melville is less occupied with objectifying the inward tendencies of his hero than with dramatizing the conquest of subjective distortion. Where Defoe holds up the island, with its alternating aspects of paradise and wilderness, as a mirror to his hero's spiritual condition ${ }^{5}$ Melville advances the same options in the spirit of a scientific hypothesis. In a colourful paragraph at the novel's start he lays out the opposed stereotypes of Polynesian life and encourages his reader to guess which picture is the truer: 
The Marquesas! What strange visions of outlandish things does the very name spirit up! Naked houris - cannibal banquets - groves of cocoanut - coral reefs - tattooed chiefs - and bamboo temples; sunny valleys planted with bread-fruit-trees - carved canoes dancing on the flashing blue waters - savage woodlands guarded by horrible idols heathenish rites and human sacrifices.

Such were the strangely jumbled anticipations that haunted me during our passage from the cruising ground. I felt an irresistible curiosity to see those islands ...

In line with this typecasting are the reputations accruing to the two principal tribes of the region: while the Happars supposedly enjoy a monopoly of the virtues the Typees, tucked away in the depths of an inland valley, collect every dark aspersion. The fiction serves both as a goad to Melville's polemic and as a source of suspense that drives the narrative. "Typee or Happar?", the question re-echoes through the early chapters of the story, and in accordance with his sharply contrastive expectations, Tommo retails two versions of the landscape, the one romantically idyllic,

Down each of these little valleys flows a clear stream, here and there assuming the form of a slender cascade, then stealing invisibly along until it bursts upon the sight again in larger and more noisy waterfalls, and at last demurely wanders along to the sea (p.59) 
My thirst was gone, and I fairly loathed the water. Starting to my feet, the sight of those dank rocks, oozing forth moisture at every crevice, and the dark stream shooting along its dismal channel, sent fresh chills through my shivering frame.

As Tommo and Toby descend into the fearsome chasms that lie between the coastal mountains and the interior they are "plunged into despair" ( p.95) and their apprehension is heightened when they discover a footpath that spells out some imminent encounter. Melville most aptly relates their feelings of discomfort at this moment to Crusoe's discovery of the footprint ( $\mathrm{p} .85$ ), and the allusion follows shortly on a paragraph steeped in the imagery and even the language of Defoe: 6

The whole landscape seemed one unbroken solitude, the interior of the island having apparently been untenanted since the morning of the creation; and as we advanced through this wilderness, our voices sounded strangely in our ears, as though human accents had never before disturbed the fearful silence of the place.

Melville uses his setting here to register mood. Tommo's anxiety over his leg, and the sense of isolation engendered by it, are made palpable in the lowering atmosphere he introduces into a scene untouched "since the morning of the creation". A similar subjectivity is signalled later when Tommo, rendered helpless by his pain and now entirely dependent on his porter, pronounces the main path though the valley to be as impenetrable "as the 
recesses of a wilderness" (p.I39). Tommo's obscure hurt serves several thematic ends (his reliance on Western skills being one of them $)^{7}$ but its richest pay-off is as a symbol of a general debility. When we see him enter the virtually unfallen realm of the Typees as a oripple limping into paradise, Melville appears for the moment to be attempting something like Defoe's allegorical treatments of original sin:

one of my legs was swelled to such a degree, and pained me so acutely, that I half suspected I had been bitten by some venomous reptile, the congenial inhabitant of the chasm from which we had lately emerged. I may here remark by the way - what I subsequently learned - that all the islands of Polynesia enjoy the reputation, in common with the Hibernian isle, of being free from the presence of any vipers; though whether Saint Patrick ever visited them, is a question I shall not attempt to decide.

As the feverish sensation increased upon me .... I chanced to push aside a branch, and by doing so suddenly disclosed to my view a scene which even now I can recall with all the vividness of the first impression. Had a glimpse of the gardens of Paradise been revealed to me, I could scarcely have been more ravished with the sight. (

It becomes increasingly clear, however, that Melville's concern is with a secularized version of the Fall. Just as the chasms which separate the coastal regions of the island from terra incognita foreshadow the gulf between primitive and civilized man, so the "venomous reptile" spells out the spiritual degradation of the 
Intruder in comparison with the indigene. Its coils, indeed, are more accurately identified as the notorious chains of Rousseau. Melville is out to celebrate the "state of nature" (p.45), and the words put into Tomo's mouth Typee mortarke ( Typee good, p.II6) supply the right answer to the novel's reourring question, for the unknown tribe, because they are less spoilt, turn out to be even more benign than the Happar. Told that the "penalty of the Fall presses very lightly upon the valley" ( $p .265)$ we regard the tribesmen as survivors from a privileged realm.

Once Tommo has recovered from the bout of despair into which he falls after the departure of his friend,his leg begins to heal and he allows himself for the first time to enter into the life of his new environment. It is to mark this important transition that Melville introduces an allusion to Rasselas: 8

If ever disagreeable thoughts arose in my mind, I drove them away. When I looked around the verdant recess in which I was buried, and gazed up to the summits of the lofty eminence that hemmed me in, I was well disposed to think that I was in the 'Happy Valley', and that beyond those heights there was naught but a world of care and anxiety. 9

Melville seems to have been deeply impressed by Dr Johnson's fable of the restless Abyssinian prince who escapes from the mountain-girt paradise which is his birthright in order to explore the world - 
only to return, however, to his "Happy Valley" chastened and relatively content. The lesson of Rasselas is revived in Typee by the figure of Marnoo, a Marquesan paragon who decides he is better off at home after a taste of Western life; and in Moby Diok Queequeg supplies a variation on the same pattern for, having set out to see the world, the Polynesian heir feels so disabled by it that he shrinks from ever facing his people again. IO What principally lays Typee open to Johnson's influence is the way the story revolves around two escapes, the first from the Dolly, the second from the tribe. Tommo jumps ship because he finds life on board unbearably restrictive, but once settled in the "Happy Valley" it is not long before he steps into the shoes of Rasselas, bemoaning the "narrow limits" of his "narrow valley", even to the point of wishing himself back on the decks he has earlier described as detestably "narrow" (pp.307,316,69). Melville canvasses Tommo's discontent with his own society more fully than he does his dissatisfaction with life among the Typees, but his hero's second escape exists in a state of tension with his first and out of this tension, as we shall in due course see, some of the fullest-bodied writing in the novel arises. An Augustan form contains, and finally. gives maturity to, the generous flow of primitivist sentiment.

Whereas Defoe is often happy to allow inconsistencies to lodge together, nothing is more characteristic of the Augustan enterprise than energy brought to bear on squaring up the disparate in an attempt to render issues distinct and whole. The activities 
essential to such an undertaking are built into the heroic couplet - the matching up of ideas for comparison, the disclosure of sameness in apparent antithesis or of difference in accepted identity - and they find a particular extension in the topos of travel. The visitor in a strange place evokes two fields of vision; for as Pope amusingly observes of the grand tour made by his young "Aeneas":

$$
\begin{aligned}
& \text { Intrepid then, o'er seas and lands he flew: } \\
& \text { Europe he saw, and Europe saw him too. II }
\end{aligned}
$$

Since there is no greater boon to the satirist than a standpoint that shows up the time-worn and commonplace as seemingly arbitrary, the view from outside-in was particularly favoured by early eighteenth-century writers. In Windsor-Forest (I7I3) Pope congregates "feather'd" Indians on the banks of the Thames in order to call attention to "Our Speech, our Colour, and our strange Attire"; ${ }^{\text {I2 }}$ and through the eyes of a couple of Persian explorers in Paris, Montesquieu in his Lettres Persanes (I72I) makes the customs of his society appear uncovenanted and outlandish. A similar distanced view underlies Swift's devastating account of colonial annexation in Gulliver's Travels (I726):

a crew of pirates ... set up a rotten plank or a stone for a memorial, they murder two or three dozen of the natives... Here commences a new dominion acquired with a title by divine right. I 3 
seizure" of Tahiti by the French in Typee (see Chapter III and Appendix, p.334). More central, however, to Swift's concerns is the two-way traffic in vision that sets the claims of man as a natural and as a social being in opposition as we turn from the magnified needs and importunacies of Gulliver to the intricate but heartless organization of the Lilliputians, or hover between the more complex abstractions embodied in the Houyhnhnms and Yahoos. Shifting scales and unexpected perspectives have always played an important part in general satire, and the travelogue has, in consequence, often proved an asset to it. Partly owing to this alliance, perhaps, the equation between travelling and self-discovery was sufficiently well established by the second half of the century for Sterne to observe in A Sentimental Journey (I768) that the chaise in which he sat at Calais was agitated not by the road but by the feverish movements of his pen; his next activity in the stationary remise, his seduction of the widow from Brussels, counts as a further exploration; but it soon becomes clear that the real business of the sentimental traveller is reverie, the excitation of an unremitting flow of thought and feeling. It follows from this, of course, that the traveller might as well stay put, a conclusion that Steme has no intention of shiriking: "I am of opinion, That a man would act as wisely, if he could prevail upon himself to live contented without foreign knowledge or foreign improvements". I4

For writers associated with the Enlightenment it was the metaphysical dividends rather than the substance of exploration 
I06.

that generally counted. Johnson drew the idea of Rasselas from Jerome Lobo's firsthand account of the Abyssinian custom of confining royal children in a mountain fastness, but his moral tale is given only the sketchiest geographical location; ${ }^{\text {I5 }}$ and when, indeed, he was later introduced to James Bruce who had an unprecedented knowledge of the region he affected boredom, remarking afterwards that he had not perceived "any superiority of understanding". I6 The Scottish laird was, in fact, probably the last explorer to retain a certain Augustan diffidence towards the status of his mission. In his Travels he records his jubilance on reaching the source of the Blue Nile, a goal he had nurtured for seven years, but with wry humour immediately quotes the remark of his less Quixotic companion - "you had much better leave that bog and come into the house". I7

In Rasselas (I759), in many respects the summation of the tradition we have been examining, Johnson addresses himself to the question of what constitutes man's greatest happiness. This is the criterion that guides the Abyssinian prince in his "choice of life", and his only constraint is the insuperable fact that one option will necessarily exclude others, for "no man can, at the same time, fill his cup from the source and from the mouth of the Nile" (p.79). Nature, indeed, as the poet Imlac observes, "sets her gifts on the right hand and on the left" (p.78), and the prince's choice is greatly vexed by the consideration that the essential issues are too 
comprehensive or engrossing to be surveyed at all steadily: I8

To the mind, as to the eye, it is difficult to compare with exactness objects vast in their extent, and various in their parts. Where we see or conceive the whole at once we readily. note the discriminations and decide the preference: but of two systems, of which neither can be surveyed by any human being in its full compass of magnitude and multiplicity of complication, where is the wonder, that judging of the whole by parts, I am alternately affected by one and the other as either presses on my memory or fancy?

In the terms of this metaphor, to explore is to create distance and so facilitate the comparison of objects that baulk the observer close at hand. Without some degree of reflective detachment, the implication is plain, no moral activity is possible. The immediate choice that confronts Rasselas is between his "prison of pleasure" (p.I26) and the outside world, but his dilemma touches on a series of related oppositions - between riches and poverty, precept and practioe, celibacy and marriage, Africa and Europe, freedom and confinement, to name a few. These antinomies take on increasing definition as Rasselas' experience accumulates and he balances, in company with the reader, one example against another; but in accordance with the principle that "when wrong opinions are entertained ... they mutually destroy each other and leave the mind open to truth" (p.74), Johnson shows himself less concerned to legislate than to break down hasty judgements. The debate on the relative merits of the retired life provides a case in point and, perhaps because 
it flows so instantly from the prince's circumstances, dominates much of the action. While planning his flight from the Happy Valley, Rasselas notices "new competitors for imprisonment" (p.3) gathering at the palace gates. The same irony informs Imlac's story of how he absconded from his merchant family in response to the thrill of the sea: "when I cast my eye on the expanse of waters my heart bounded like that of a prisoner escaped", exclaims the poet, soon to protest his hatred of "barren uniformity" once on it (pp.22-3). His history caps Rasselas' progress, for having won entrance to the Happy Valley and resigned himself "with joy to perpetual confinement" there, Imlac makes off with his pupil in order to escape its "perpetual vacancy" (p.35). His tale serves, however, merely as a prelude to the account of the apostate hermit who spends his days in such a dither of conflicting hopes that his future is easily foretold: "in a few years [he would] go back to his retreat, and, perhaps, if shame did not restrain, or death intercept him, return once more from his retreat into the world" (p.58).

The hermit's career keeps coming full circle but Rasselas, al though he returns to the Happy Valley, goes back to a different life. In another context, Johnson once remarked that "every man who works is confined ... you know the notion of confinement may be extended, as in the song, 'Every island is a prison'". I9 Properly sceptical of his urge for novelty and freedom Rasselas has learnt, in sum, to 
"commit [himself] again to the current of the world" (p.93). It becomes clear on his return that the imaginative distance at which he has set his former mode of life provides a measure of the difference between pleasure and happiness. Johnson's understanding of this distinction rests on the Aristotelian view that sensual gratification does not cater to the needs of the distinctively. buman, rational soul: "man ... has some desires distinct from sense which must be satisfied before he can be happy" $(p .6)$. It is for this reason that the Happy Valley fills Rasselas at last with distaste for all the "recurrence of its luxuries", as does its unflattering counterpart, the Arabian seraglio whose inmates entertain "no ideas but of the few things that were within their view" (pp.I26,I04). Rasselas' venture begins with the recognition, "I have already enjoyed too much, give me something to desire"; and it ends with a resumption of duty that promises to absorb, if only in part, his troublesome energies and relieve his "hunger of imagination" (pp.8,85). For Johnson, as for Milton and Coleridge, Mount Amhara represents an earthly paradise but one sufficiently incomplete to serve as a foil for a greater good. 20

Prominent among the many systems of thought that come under review in Rasselas is the primitivism expounded by Rousseau. Johnson summarizes the arguments of the Discours sur l'origine et les fondements de l'inégalité (I754) and parodies the abstract declaratory style of the philosophe in the chapter headed "The happiness of a 
life led according to nature" (pp.58-60). There is a decided irony here, for while Johnson believes that it is, indeed, through the expression of his nature that man attains happiness, he supposes, as Imlac explains, that it is through the redemptive institutions of society that man most nearly surmounts the fallen state. Rasselag' counsellor, however, holds civilization to blame for human misery and argues that man has only to rely on precepts "infused at nativity" and "observe the hind of the forest, and the linnet of the grove" in order to recover his natural inheritance. Johnson loathed Rousseau but his account is fairly faithful to the gist of the Second Discourse. 2 What it fails to convey is the curiously Calvinist insistence on the degradation of man that seems to have led Rousseau to subvert the traditional confidence in institutional amelioration and to discount, in particular, the idea that virtue can be won from a mutinous psyche in a recalcitrant world. The discourse opens with the assertion that society has so changed human nature as to have obliterated all trace of the divine image in man. Knowledge, however, of the "real foundations of human society" can only come from an understanding of the original state, and the philosopher has accordingly to reconstruct "the celestial and majestic simplicity impressed by the divine Author" before he can prescribe man's "real wants, and the fundamental principles of his duty". 22 In setting about this task Rousseau necessarily comes into conflict with Hobbes, and the nature of his disagreement proves peculiarly revealing, for he maintains with much brilliance that the 
primitive state depicted in Leviathan is the projection of civilized man's depravity, that the greed and strife attributed to the hypothetical, natural man are, in fact, the product of the thinker's own diseased condition:

In reasoning upon the principles which this author hath laid down, he ought to have said, "the state of nature, being that in which the care of our own preservation is the least prejudicial to that of others, was consequently the best calculated for peace, and the most agreeable to mankind." But he advances the direct contrary, in consequence of having improperly admitted into the care of savage man's self-preservation, the zratification of a variety of passions, which owe their rise to society, and which have rendered laws necessary. 23

In the course of his essay Rousseau suggests, more than once, that thought is itself a symptom of man's corruption; and his procedure, in essence, is to sweep aside Hobbes's premises and build instead on his faith in the benevolence of creation. ${ }^{24}$ But although he prides himself, perhaps paradoxically, on the purely intellectual nature of his speculation, Rousseau shows himself ready at times to draw on evidence pertaining to primitive tribes, and in this connection identifies the Caribbeans as the "people who have as yet least of all deviated from a state of nature". 25 He may well have been influenced by the reports issued, in regular Relations, by Jesuit missionaries some of whom surmised that the Indians might be free of original sin. ${ }^{26}$ It seems likely that he, in his turn, reinforced the impressions made on French explorers by the South Sea islanders 
in the next decade; in Diderot's rhapsodic Supplément au Voyage de Bougainville (I796), at least, his presence is conspicuous.

Of Melville's debt to Rousseau in Typee there can be no doubt. Quite apart from an important reference to the Confessions which we shall come to later, two inset essays (Chapters I7, 27), the first orfering a comparison between the tribe and "more enlightened" communities, the second a survey of the islanders' mode of life, reveal a close acquaintance with the argument of the Discourse on Inequality. It is not simply that Melville is so often carried away by his enthusiasm that he exceeds his empirical authority or that the more detailed observations filtered through his narrative sometimes contradict the orinciples he enunciates as an essayist, but that his emphasis shows a conscious alignment with Rousseau's analysis. He follows the philosopher in diaznosing property and self-esteem as the root causes of evil, and holds up the anarchism of the Typees as a model of the true polis:

how came they without the aid of established law, to exhibit, in so eminent a degree, that social order which is the greatest blessing and highest pride of the social state?

$(p .27 I)$

Lise Rousseau again, he attributes the harmony of island life to an innate code:

It is to this indwelling, this universally diffused perception of what is just and noble, that the integrity of the 
Marquesans in their intercourse with each other, is to be attributed.

$(p .272)$

Since the expression of their goodness is unconstrained, the Typees display a whole catalogue of assets: "perpetual hilarity" (p.I8I), "unanimity of feeling" (p.274), "honesty" (p.27I), "charity" (p.27I), physical beauty, perfect health and gentleness. More frequently, however, Melville defines the Marquesan virtues by supplying a list of cancelled Western vices, a technique that has always come in handy in describing the golden age. ${ }^{27}$ So, for instance, we are told,

the heart-burnings, the jealousies, the social rivalries, the family dissensions, and the thousand self-inflicted discomforts of refined life, which malse up in units the swelling aggregate of human misery, are unknown among these unsophisticated people.

And at one point treated to a page-long inventory of negatived ills ("no cares, griefs, troubles ... no quarrelling, no contention", pp.I8I-2) which, even if its component items are fairly easily deduced, probably enjoys the distinction of being the most thorough in existence. It is when Melville contraverts the deepest springs of suffering, conferring on the Typees not only a total absence of sexual jealousy, but liberty of conscience, a sceptioal attitude towards the supernatural, and virtual equality between the sexes and social ranks, that the text begins to look dootrinaire. Unsurprisingly, his negation of sexual jealousy bears a tell-tale 
resemblance to Rousseau's. 28

Though Melville's philosophical bias declares itself most plainly in the novel's interludes of discursive prose, he shows a wonderful talent for enclosing meaning in the anecdotal and descriptive details of his narrative. 29 It is through such sleight of hand that the directions of the novel are made clear from the first. Shortly after Tommo places the blame for the unpleasantness aboard the Dolly on the Captain's abuse of authority, he describes the provisioning of the ship in such a way as to implant the idea that natural goodness is continually being done to death:

The owners, who officiate as caterers for the voyage, supply the larder with an abundance of dainties. Delicate morsels of beef and pork, cut on scientific principles from every part of the animal, and of all conceivable shapes and sizes, are carefully packed in salt, and stored away in barrels; affording a never-ending variety in their different degrees of toughness, and in the peculiarities of their saline properties. Choice old water too, decanted into stout six-barrel-casks, and two pints of which is allowed every day to each soul on board; together with ample store of sea-bread, previously reduced to a state of petrification, with a view to preserve it either from decay or consumption ... $(\mathrm{pp} .56-7)$

In sharp contrast to the stale, deck-bound crew are the naked Marquesans, introduced a few pages earlier, whose dancing heads as they swim towards the ship materialize from garlands of coconuts, 
so that here we see the reverse exchange of food into flesh:

As I leaned curiously over the side, endeavouring to solve their mysterious movements, one mass far in advance of the rest attracted my attention. In its centre was something I could take for nothing else than a cocoanut, but which I certainly considered one of the most extraordinary specimens of the fruit I had ever seen. It kept twirling and dancing about among the rest in the most singular manner, and as it drew nearer I thought it bore a remarkable resemblance to the brown shaven skull of one of the savages. Presently it betrayed a pair of eyes ...

Melville would have owed the idea for this scene to a remarkable chapter from Fenimore Cooper's The Prairie (I827) in which a Pamee scout, carefully concealed among foliage, gradually assumes animate form in the eyes of two observers. The shaven head of the Indian is variously taken for a pile of leaves, a stone, and a coiled-up snake, before a "pair of dark, glaring, and moving eyeballs" refuse to be overlooked. ${ }^{30}$ Cooper devises the episode to dramatize frontier attitudes towards the Pawnees, whom one of the observers proceeds to characterize as "a violent race ... difficult to define or class, within the usual boundaries of definitions". 31 Melville turns the metamorphosis to his own account, creating his noble beings out of an idyllic setting so as to forge a powerful emblem of the natural man. From there it is an easy step to imaging the island's inner valley as an Eden. Glimpsed from the coastal ridge the "gardens of Paradise" enfold a community whose "sunmer garb of Eden" lays bare the "naked simplicity of nature", an embodiment of all the West has 
lost (pp.90, I35, 247-8):

Stripped of the cunning artifices of the tailor, and standing forth in the garb of Eden - what a sorry set of round-shouldered, spindle-shanked, crane-necked varlets would civilized men appear! Stuffed calves, padded breasts, and scientifically cut pantaloons would then avail them nothing, and the effect would be truly deplorable. (p.248)

In a text where physis is given precedence over nomos it seems right that the incarnate idea should do most of the work.

In Typee the narrator tacks between the islanders and the civilized West. He looks out, that is to say, as well as looking in,but in so far as he gazes through the spectacles of Rousseau, the one prospect is as dark as the other is bright. Across this simple scheme there is played, howover, a further tonal contrast resulting in a more intricate design, a chequer-work more in keeping with the multiple perspectives relished by the writers of Augustan satire, and truer to Melville's own experience. In determining to escape from his "Happy Valley" as he has earlier escaped from the whaler, Tommo opens a positive as well as nesative aspect to each of his domiciles. He succeeds for the most part in accunting for the changes in feeling that lead to his flight from Nukahiva without reneging on his championship of the Typees; but the shift is one that involves him in some subtle modulations of attitude, some finely conducted comedy of misapprehension, and leaves him still with a residue of inconsistency. 
At the start of the novel Tommo yearns for a taste of the "verdant scenery" which he glimpses from the deck of his "detested old vessel", shortly before the end he rejoices ecstatically in the "flashing billows" of the surf breaking upon a beach $(p p .69,328)$. In either case it is a sense of constriction that prompts Tommo to relocate his horizons. His first inkling of entrapment in the valley comes after Toby has been foiled on his first attempt to reach the harbour for medical supplies. That it is a Happar rather than Typee weapon that stops him, further gives the lie to the idea that the two tribes are all good and all bad. But myths die hard and while it is clear that the "horrible character" inputed to the Typees is "wholly undeserved", the sense of restricted freedom greatly darkens the character of the Happar: "we were hemmed in by hostile tribes ... we could not hope to pass ... without encountering the effects of their savage resentment" (pp.I48,I54). It is at this juncture that Tommo's attendant, Kory-Kory - variously described as gaoler and friend - tries to convince his charge that it would be altogether unreasonable to think of flight. But his picture of the island as a paradise so utterly fails to take personal freedom into account that it amounts to a travesty, and leaves Tommo with a headache:

\footnotetext{
'Ah! Typee mortakee! - nuee, nuee mioree - nuee, nuee wai nuee, nuee poee-poee - nuee, nuee kokoo - ab! nuee, nuee
} 
kiki - ah! nuee, nuee, nuee!' Which literally interpreted as before, would imply, 'Ah, Typee! isn't it a fine place though! - no danger of starving here, I tell you! - plenty of bread-fruit - plenty of water - plenty of pudding - ah! plenty of everything! ah! heaps, heaps, heaps!' All this was accompanied by a running commentary of signs and zertures which it was impossible not to comprehend.

This is not Eden but the land of Cockaigne as depicted by Breughel; and when Kory-Kory reports on the afterlife, later in the novel, the same shortcomings are evident:
the realms of bliss, and bread-fruit - the Polynesian heaven - where every moment the bread-fruit trees dropped their ripened spheres to the ground, and where there was no end to the cocoanuts and bananas: there they reposed through the livelong eternity upon mats much finer than those of Typee; and every day bathed their glowing limbs in rivers of cocoanut oil.

Kory-Kory's paradise is too replete to allow for aspiration whioh is why, on the principle that "a bird in the hand is worth two in the bush" $(p .239)$, he is ready to admit that he prefers the life he enjoys in the present. What fully engages Tommo, however, is the myth of the chieftain who sails to the next world in his warboat. His sympathies are with the "immortal spirit yearning after the unknown" and the heaven he pictures is, after the manner of the Island of Love in Camoens' epic, the reward for strenuous exertion. ${ }^{32}$ Envisaging the next world in its approach 
rather than in his possession Tommo, like a true explorer, sets the magic landfall in the offing:

I see thy canoe cleaving the bright waves, which die away on those dimly looming shores of Paradise.

By including a full range of heavens Melville accounts for his hero's increasing languishment in an earthly paradise.

But if all the delights of Typee fail to rid Tommo of his "anxiety to escape from a captivity"(p.200), Kory-Kory has another string to his bow: the dangers of traversing the territory of the savage Happar. Over and above the irony afforded by this inversion of the stereotype there is the comic symmetry of Nestern and Marquesan modes of denigration to attend to. But the scene in which Kory-Kory impresses his listener with the rampant cannibalism of the Happar offers still more,for in the course of a desperate attempt to convey his meaning the Typee anologist nibbles at the inside of Tommo's arm. His confusing antics as he switches, without ever quite losing himself, from the role of commentator to agent seem, indeed, to undo any hard and fast distinction between the neighbouring tribes:

Thus far he explained himself by a variety of gestures, during the performance of which he would dart out of the house, and point abhorrently towards the Happar valley; running in to us again with a rapidity that showed he was fearful he would lose one part of his meaning before he 
could complete the other; and continuing his illustrations by seizing the fleshy part of my arm in his teeth, intimating by the operation that the people who lived over in that direction would like nothing better then to treat me in that manner.

Despite Kory-Kory's vehement denials, Tommo's suspicions of Typeo cannibalism persist. First reawakened by a dark thought as they sit down to a dish of pig with their hosts ("a baked baby, by the soul of Captain Cook!") his fears on this occasion are firmly if rather knowingly - allayed:

When the taper came, I gazed eagerly into the vessel, and recognized the mutilated remains of a juvenile porker: 'Puarkee!' exclaimed Kory-Kory, looking complacently at the dish.

They remain inactive for some time to come for, as he resigns himself to the pleasures of the "Happy Valley", relegating evil to an outer sphere ("beyond those heights there was naught but a world of care and anxiety", p.I79) Tommo increasingly exchanges the images of Typee and Happar. Toby's failure to reappear temporarily brings back his original prejudices leading him to brand his captors as "nothing better than a set of cannibals" ( $p .172$ ), but he adapts little by little to the rhythms of Typee life, and is soon revelling in its erotic opportunities. He is quick to shed his sailor's uniform and at feasts takes part in the dancing stripped to the waist. In a series of idyllic scenes he reports on his 
courtship of the beautiful and often naked Fayaway who, by special dispensation from taboo, joins him in his boat. As they drift across the sheets of water Tommo's integration seems al together complete.

But although he overcomes his own taboos to the point of nerving himself to eat raw fish, Tommo absolutely refuses to submit to any tattooing of his face; and it is this reserve of loyalty to his Western identity that proves to be the watershed in his developing relationship with the Typees. As social pressure mounts, his resistance grows until he determines to escape. The old Typee image is now reinstated in force, and Melville deliberately points to the way his hero's outlook has come full circle, for at the height of the scene in which Tommo receives positive proof of the tribe's cannibalistic rites it is again Kory-Kory who steps forward to exclaim "Puarkee! puarkee!", this time over a mess of human bones $(p \cdot 3 I 6)$.

Though the disclosure does much to pave the way for Tommo's departure it is not allowed to interfere seriously with his polemical defence of the islanders. Melville retums to the task he addresses in the novel's opening refrain "Typee or Happar?" his rebuttal of the depreciatory images that suit the book of both colonialist and missionary: 
entering their valley, as I did, under the most erroneous impressions of their character, I was soon led to exclaim in amazement: 'Are these the ferocious savages, the blood-thirsty cannibals of whom I have heard such frightful tales! They deal more kindly with each other, and are more humane than many who study essays on virtue and benevolence, and who repeat every night that beautiful prayer breathed first by the lips of the divine and gentle Jesus.'

Typee takes its place in a debate on the rights and wrongs of the Western presence in the South Seas, a debate - later to be joined by Ballantyne - in which Melville sides with Kotzebue against Darwin. 33 The fervour with which the narrator takes up the cause of the islanders leads to occasional inconsistency. After a spirited treatment of cannibalism in the vein of Montaigne's famous essay, the practice is twice given out as being confined in the Pacific to the bodies of slain enemies alone (pp.I80-I,278); yet Tommo discovers a European head among the relics at the Ti, and Marnoo's warning, "you get well, he kill you, eat you, hang you head up there" carries full weight (pp.309,3I9). On the whole, however, the paradox of imprisonment in paradise leads Melville into remarkably little contradiction, for he hits on a simple resolution to the problem of why his hero chooses to escape from a Iife that engrosses the greater part of "the virtues of humanity" (p.274). 34 While Tommo's refusal to have his face tattooed points to certain stubborn limits of identity, his situation presents a case 
of "One Law for the Lion and Ox is Oppression". 35

On first meeting Marnoo, the Marquesan who has turned his back on the West, Tommo is deeply humiliated to find himself ignored by this dashing visitor who rivets the attention of every Typee. Noting his fit of pique, Tommo comments ruefully on the voracity that underlies all heroic temper:

These were my feelings at the moment, and they were
prompted by that glorious principle inherent in all
heroic natures - the strong-rooted determination to
have the bigrest share of the pudding or to go
without any of it.
(p.I95)

His diagnosis evidently extends, in part, to Marnoo too, for it turns out that the "Polynesian Apol10" has carefully planned his show of disregard:

At this declaration of the exalted opinion I had formed of him, he appeared vastly gratified, and gave me to understand that he had purposely behaved in that manner, in order to increase my astonishment.

The episode is given considerable emphasis not only by Tommo's indication that such experience is common to civilized life (p.I95), but by the contrast it offers to the unassuming and unassertive manners of the islanders which frequently come in for comment. Tommo singles out "unanimity of feeling" ( .274 ) as the most admirable trait of the Typees, and twice dilates on 
the absence of quarrels or disputes among them, adding on the second occasion:

[they] were bound together by the ties of strong affection. The love of kindred I did not so much perceive, for it seemed blended in the general love; and where all were treated as brothers and sisters, it was hard to tell who were actually related to each other by blood.

Again, it is in marked contrast to any bevy of belles at a public resort that the Typee girls are said to be quite without "envyings of each other's charms" ( $p . I c 2$ ). Taken together, these scattered remarks and scenes imply that it is principally self-esteem that causes the divide betwoen primitive and civilized man. And when, with a further hint of self-mockery at his vanity, the narrator analyses his horror at the thought of facial tattooing, this decisive issue, too, is tied to the same theme:
What an object he would have made of me! ... I was fairly driven to despair; nothing but the utter ruin of my 'face divine', as the poets call it, would, I perceived, satisfy the inezorable Mehevi and his chiefs.

But however wry he may be at his own expense, the narrator makes it clear that it is the force of "heroic nature" that endows Marnoo with special appeal. (we are even told that "the natural quickness of the savage had been wonderfully improved by his intercourse with the white men", p.I99). Nor is there any mistaking the "strong-rooted determination" that fuels Tommo's adventures, leading 
I25.

him to exhaust horizon after horizon. The restlessness that prompts him first to turm his back on the Dolly and later to regret the lack of sophisticated company, even to welcome the sight of a naval uniform, is itself, it seems, a necessary condition of civility (pp.I56,328).

The Augustan convention of contrary perspectives, so deeply written into the structure of lypee, provides a critique of the novel's more overt primitivism. It discourages readers, for one thing, from supposing that they are at bottom as sweet-minded as the islanders; and when the narrator remarks, towards the close, that his subsequent experiences on board a man-of-war have "nearly overturned all [his] previous theories" ( $p .274)$, he comes close to withdrawing his ideology altogether. His debt to Rousseau is, in any case, less to the rhetorician of the First Discourse than to the speculative thinker of the second who identifies amour-oropre the psychological correlate to the various material causes of civilized man's misfortune - as the force responsible for tearing apart the social fabric in the last and most attractive phase of primitive life. ${ }^{36}$ In sum, Melville relies on the Rousseau who, rather than counselling despair in the face of a hopeless future, celebrates the virtues that he strategically confers on the past the Rousseau who bends the wish "to go back" into constructive aims addressed to the present. 37 In the last analysis it is the high premium attached to the most immediate qualities of everyday existence - to sensation and to feeling - that underwrites Rousseau's 
complicated salvage operation on the primitive; and it is precisely in this connection that Melville chooses to make his debt explicit, when he gives substance to the privileged existence of the Marquesans by pointing to that state of physical exhilaration memorably evoked in the Confessions:

[The Typees'] continual happiness ... sprang principally from that all-pervading sensation which Rousseau has told us he at one time experienced, the mere buoyant sense of a bealthful physical existence. (p.I83)

In the passage in question Rousseau recounts how, after declaring himself the devoted slave of Mme de Warens, he set out on foot across the Alps to seek his fortune:

I walked gaily on my way with my pious guide and his lively companion. No misadventure disturbed my journey. I was as happy physically and mentally as at any time in my life. I was young, vigorous, healthy, fearless, and full of confidence in myself and others. I was enjoying that short but precious moment in life when its overflowing fullness expands, so to speak, one's whole being, and lends all nature, in one's eyes, the charm of one's own existence ... Every object I saw seemed a guarantee of my future happiness. I saw in my imagination a country feast in every house and wild game in every meadow, bathing in every river and fishing from every bank; delicious fruit on every tree and voluptuous assignations in its shade; bowls of milk and cream on the mountain-sides, everywhere the delights of idleness, and peace and simplicity, and the joy of going one knew not where. 38 
The whole paragraph might serve as an epigraph to Typee for it not only marks out that meeting ground of the primitive and sophisticated which is so central a concern of the text,but deals in the same coupling of exploratory excitement and sensual luxuriance that gives Melville's first work its distinctive blaze. There is, however, one difference in emphasis. From the moment we are introduced to the "gay and dapper young cock" (p.36) cooped aboard the Dolly, we are prepared for the many romps and bathing scenes that add up, in view of the date, to a remarkably radiant plea for the joy of sexuality. The language and attitudes belong for the most part to the eighteenth century,

I hapoened to pop upon Mehevi three or four times when he was romping - in a most undignified manner for a warrior king - with one of the prettiest little witches in the valley

but the Victorian novel would have to wait for Thomas Hardy before it could match Melville's candour. 
Captain Ahab and the Albatross:

Moby Dick in a period context

Only the whale puts an end to the Pequod's circuit of the oceans and nothing stops the narrator, who introduces himself as Ishmael, from ranging over history. Moby Dick $i$ global in its scope and to this feature, more than any other, it owes the aura of timelessness which many fascinated critics note. In his study of the novel charles Olson, for example, writes of Melville:

He had the sea of himself ... It enabled him to draw up from Shakespeare. It made Noah, and Moses, contemporary to him. History was ritual and repetition when Melville's imagination was at its own proper beat. I

And D.H. Lawrence was moved by the brooding presence of the past in the book to compare American literature to a transplanted tree that instead of coming new "ran nore swiftly into age". ${ }^{2}$ The temporal layering of Moby Dick is partly a reflection of the bravura with which Melville, drawing on a bost of disparate influences, fashioned a literary idiom for himself; but it is also $z$ device tuned to the novel's special concerns. Melville knows what he is about when he christens the wind whistling through New Bedford Euroclydon after the north-easter that blasted St Paul in his boat off Crete $(p .34)$ : he is leading up to a subject and setting that are "antemosaic", or even "pre-adamite", in short to a realm that he will determinedly present as the "the unwarped primal world" $(p p .582,530) .^{3}$ The immanence of the primeval is a recurrent 
theme in novels dealing with exploration, but the stratified text of Moby Dick is exceptionally well suited to its treatment. Ishmael's delvings into the past are inspired, as much as his voyage, by "an everlasting itch for things remote" (p.30), and his narrative, in both its allusiveness and tessellated texture, sails as far from stylistic norms as the Pequod beyond the New England horizon. So successful, indeed, is Melville at passing himself off as the contemporary of Noah and Moses that his links with his age have suffered from relative neglect. ${ }^{4}$ Yet to isolate what is most distinctive of his period in Moby Dick (I85I) is to move, by degrees, towards the novel's centre.

Melville originally made his name as an explorer, and shortly before the publication of his masterpiece mefully remarked that he would continue to exist for his public as the "man who lived among the cannibals". 5 Set in the South seas his first two novels, Typee (I846) and Omoo (I847), show an obvious kinship with the travel book. 6 Although a self-advertising fictionality sets Moby Dick apart, one of its most striking features, a curious juxtaposing of narrative and discursive material, clearly reflects a crisis that overtook travel writing in the early half of the nineteenth century. In a history of the Royal Geographical Society, Ian Cameron comments on the growing scientific impulse in this period that went a long way to transforming the "descriptive narrative" favoured by earlier explorers: 
... no-one could doubt the commitment to science of an eighteenth-oentury explorer such as Cook. It would, however, be fair to say that in the early nineteenth century men like Humboldt and Ritter did bring about a change in the concept of what geography was about. Before them its essence had been descriptive narrative. After them, its essence was detailed investigation in a number of specialized disciplines botany, for example, or hydrography, geology or geomorphology. 7

Perhaps the best single example of the change is provided by Aspects of Nature (I808), the widely influential travelogue in which Humboldt attempted, without full success, to keep personal narrative separate from sections of "scientific elucidation". $E$ Later in his career, while surveying the writings of explorers, he accounted, with evident regret, for the bifurcation he had done much to foster. Turning to the example of travels from the early Renaissance he observes:

They had the unity which every work of art requires: everything was connected with an action, i.e. subordinated to the journey itself ... This attractive unity of composition is necessarily wanting in the greater part of modern travels, and especially in those undertaken for scientific purposes; in these, what is done yields precedence to what is observed; the action almost disappears under the multitude of observations.?

Humboldt's position is an instructive one. For while he celebrates the ideal of a unified sensibility - praising Columbus for the way he "teaches us anew that the creative imagination of the poet exists in the Discoverer" - he insists on the inductive foundations of all knowledge - "there is nothing stable and certain but facts". I0 Schiller thought he had put in a decisive stroke when he remarked 
of the explorer, "his mind is that cold, dissecting kind that wants all nature to be shamelessly exposed to scrutiny"; but his strictures hardly meet the case. II Humboldt dismantles, it is true, and readily admits his inability to integrate, but his overriding aim, as he repeatedly states, is to instate a more inclusive order. His ideal, he observes in the preface to Cosmos, is "to discern physical phenomena in their widest mutual connection, and to comprehend Nature as a whole, animated and moved by inward forces". I2 Tantalized by discrete and partially assembled fragments Humboldt rejoices in a pantheism typical of the Romantic literature in which his sensibility was grounded.

Many explorers in Humboldt's wake laboured under an obligation to be scientifio, and Melville was among them. An empirical impulse, already apparent in the ethnography that punctuates Typee, becomes more pronounced, and at the same time more self-conscious, with Moby Dick. The interspersed chapters on whales and whaling are part of an attempt to supply the definitive account of a creature which from either a "scientific or poetic" point of view "lives not oomplete in any literature" (p.I8I). Only thinly disguised as Ishmael, Melville adds firsthand experience to his gleanings from the authorities and we find him roised in this role between the modern scientific journalist and the seventeenth-century writer of anatomies. Unlike Sir Thomas Browne who, as Lytton Strachey remarks, was inductive "just up to the point where the examination of detail ends, and its co-ordination begins", Melville assembles "substantiated facts" with an eye to such imposing tasks as a "systematization of cetology" 
(pp.I56,I8I). I3Unlike the scientific journalist, on the other hand, he submits the job of fact-gathering to a good deal of ironic play. If the sub-sub-librarian who hoards quotations about whales falls short of "veritable gospel cetology" for lack of system, even the experts, comically nicknamed Coffin, Sleet or Fogo Von Slaok, come in for their share of debunking. Ishmael is determined to address the whole man to the whole whale and while the longest run of referential chapters deals in anatomy of a literal kind carossses are sliced, shredded and inspected from every angle before Moby Dick hoves in view - the ultimate verdict is that the beast defies all analysis: "Dissect him how I may, then, I but go skin deep; I know him not, and never will" (p.486). It is in the same spirit that Ahab tramples on his quadrant and curses Science, exclaiming "with thy impotence thou insultest the sun:" (p.634). But if Melville dwells on the limits of empirical knowledge he is also ready at times to expose belief to a reductive materialism. The tendency of Ishmael's brisk lecture to Queequeg on "the rise and progress of primitive religions" is that self-denial breaks "the obvious laws of Hygiene and common sense", and that supernatural awe is born of "undigested apple-dumpling"(pp.I25-6). These views do not stop Ishmael, however, from professing himself a member of the "great and everlasting First Congregation" in which all men splice hands (p.I28), and his frequent intimations of sympatbetic accord with the universe constitute, as we shall see, one of the poles in the novel's dialectic movement. What Melville evidently had in view was a text sufficiently comprehensive 
to include Leyden jars and oycloids as well as Faustian pacts, a tert moreover that would not only encompass imagination and science but witness their skirmish. The claims he makes for organic unity are scarcely grounded ( .380$)$, for though the novel's expository parts are often among its most vivid and even thematically dense, there is much that is taoked on by mere expedience. Only intermittently is the reader aware of a synthesis that matches the privileged moments in which for Ishmael "fact and fancy, half-way meeting, interpenetrate, and form one seamless whole" (p.623).

Corresponding exactly to what some later psychologists would name the "oceanic feeling", Ishmael's moments of mystical illumination are frequently associated with sunlight falling on a mild, swell-swept sea. I4 Melville evokes these moods superbly but always with a degree of critical reserve. In the chapter headed "The Gilder" from which the last quotation comes he goes out of his way, for example, to indicate what Ishmael's vision of coherence excludes:

when beholding the tranquil beauty and brilliancy of the ocean's skin, one forgets the tiger heart that pants beneath it; and would not willingly remember, that this velvet paw but conceals a remorseless fang. (p.623)

Similarly, in the famous passage from "The Mast-Head", it is the thought of coming unstuck and crashing down that puts an end to the account of what every tyro in the crow's-nest feels on gazing into the depths and losing touch with the boundaries of self: 
him; every dimly-discovered, uprising fin of some undiscernible form, seems to him the embodiment of those elusive thoughts that only people the soul by continually flitting through it. In this enchanted mood, thy spirit ebbs away to whence it came; becomes diffused through time and space; like Cranmer's sprinkled Pantheistic ashes, forming at last a part of every shore the round globe over ... But while this sleep, this dream is on ye, move your foot or hand an inch; slip your hold at all; and your identity comes back in horror.

The admonitory note is sounded again when Tashtego slips into the balmy spermaceti filling the well he has dug from the head of the Pequod's first catch:

had Tashtego perished in that head, it had been a very precious perishing ... Only one sweeter end can readily be recalled - the delicious death of an Ohio honey-hunter, who seeking honey in the crotch of a hollow tree, found such exceeding store of it, that leaning too far over, it sucked him in.

Melville is determined to renounce all love of easeful death but, from a letter written to Nathaniel Hawthorne while at work on Moby Dick, it is clear that he was susceptible to the feelings that he begins by relegating sternly to Romantic poetry:

In reading some of Goethe's sayings, so worshipped by his votaries, I came across this, "Live in the all." That is to say, your separate identity is but a wretohed one, - good; but get out of yourself, spread and expand yourself, and bring to yourself the tinglings of life that are felt in the flowers and the woods, that are felt in the planets Saturn and Venus, and the Fixed Stars. What nonsense! Here is a fellow with a raging toothache. "My dear boy," Goethe says to him, "you are 
sorely afflicted with that tooth; but you must live in the all, and then you will be happy!" As with all great genius, there is an immense deal of flumery in Goethe, and in proportion to my own contaot with him, a monstrous deal of it in me...

P.S. "Amen!" saith Hawthorne.

N.B. This "all" feeling, though, there is some truth in. You must often have felt it, lying on the grass on a warm summer's day. Your legs seem to send out shoots into the earth. Your hair feels like leaves upon your head. This is the all feoling. But what plays the mischief with the truth is that men will insist upon the universal application of a temporary feeling or opinion. I5

Melville looked on Haw thorne as a teller of dark truths: "even his bright gildings but fringe and play upon the edges of thunder-clouds", he had recently observed in his celebrated essay on the novelist. I6 But even if we suppose that his friend required some preparation for Ishmael's benign moods, there is no mistaking the scepticism that Melville displays towards Ineinsbildung, the one-making which amounted to a central tenet of faith among the early German Romantics. I7

In a compelling survey of early nineteenth-century thought from his study The Wheel of Empire, Alan Sandison boldly compares political with epistemological theory and proposes a relation between the rise of imperialism and changing notions of sensibilia. He outlines Hegel's idea that the subject recovers selfhood in absorbing the object, and shows how it gradually gave ground in the period to the view that the ego constitutes itself by resisting the external world. He goes on: 
Awareness of the rupture between subject and object and a yearning for reunion is, of course, one of the chief characteristics of Romantic writing. "What is called Romanticism in England and on the Continent is ... the concern for the reconciliation of subject and object, man and nature, consciousness and unconsciousness". But though the crisis in which the 'imperial ' writers ... find themselves is basioally Romantic, centred as it is in an intense awareness of this dissociation, they no longer really believe in the possibility of reconciliation. Theirs is a papiermaché grail: it is without intrinsic worth and with a purpose that is purely and confessedly psychological. No longer was there any possible prospect of that matter-spirit contimum which according to Albert Guerard is the proper object of the Romantic experience ... In a sense what they sought now was less reconciliation than 'victory'. I8

These conclusions have an obvious bearing on Moby Dick, for the two opposing attitudes towards nature which Sandison adumbrates here correspond to those which Melville dramatizes in the figures of Ishmael and Ahab. Where Ishmael sets out to discover the external world Ahab pits himself against it; where the narrator assimilates, the hero looks for triumph. But while, taken together, Ishmael and Ahab may be seen to illustrate Keats' distinction between "men of genius" and "men of power", or the clash between Goethe's "live in the all" and Fichte's contrary injunction to posit and then oppose a non-ego, in neither does the stereotypical trait wholly dominate. I9 Melville is more concerned to examine than propound and, to this end, Ishmael shows himself aware of the way his pantheistic intuitions threaten his utilitarian self, and Ahab partly revives the tendencies that he has gagged to make room for the "creature he creates" ( $p .272)$. 
We are alerted, moreover, to the destructiveness that inheres in eitber ideal. The fate of Narcissus awaits those who try to embrace the human image reflected off the surface of a far from benevolent ocean ( $p .26)$; but, conversely, a hostile attitude towards the world entails perpetual war with the self. Issuing from an invisible source, a flickering irony plays over the heads of both narrator and hero. So defenceless is negative capability that Ishmael comes close to joining the quest that represents a negation of his own. "A wild, mystical, sympathetical feeling was in me; Ahab's quenchless foud seemed mine", he is once moved to remark (p.239); and only narrowly does he escape embroilment in the self-consuming vortex made by the sinking Pequod (p.724). Ahab, on the other hand, whose mission begins in stark parody of Ishmael's enchanted merging - "his torn body and gashed soul bled into one another; and so interfusing, made him mad" ( $p .248)$, increasingly finds himself, for all his vaunted autonomy of spirit, a creature of ivory appendages, a pawn of the material world. So it is that Melville throws two opposing shibboleths of his period into dynamic relation and, in the midst of frenzied action, quietly registers the result.

The attitudes that Ishmael and Ahab display towards the universe emerge, it hardly needs saying, in their feelings for Moby Dick. The White whale takes its emotional colouring from the perceiver, and there is no suggestion of whitewashing when both Starbuck and the genial Captain of the Enderby who has lost his right arm to it, insist that the violence of the beast proceeds from instinct rather than the malice imputed to it $(p p \cdot 220,564)$. The sane thing on losing 
a limb to an exceptionally aggressive whale, the Captain confides, is to steer clear and preserve the others (p.563). To Ahab, however, who feeds on the vengeance he nurtures, the whale appears as a mere front for a universe which he imagines to be malignly disposed towards man:

some unknown but still reasoning thing puts forth the mouldings of its features from behind the unreasoning mask. If man will strike, strike through the mask!

His terror and loathing of the "dumb brute" are to some extent self-directed, for the whale, as well as providing him with an emblem of the cruelties of existence, serves as a dumping-ground for the fury that rages in his breast. His campaign otherwise resembles the magic rite of damaging some easily grasped image in order to hit out at some less touchable ill:

That intangible malignity which has been from the beginning: to whose dominion even the modern Christians ascribe one-half of the worlds; which the ancient Ophites of the east reverenced in their statue devil; - Ahab did not fall down and worship it like them; but deliriously transferring its idea to the abhorred white whale, he pitted himself, all mutilated, against it. (p.247)

Yet since the many grievances which Ahab has "piled upon the whale's white hump" ( $p .247)$ beg the question of his own culpability, we are left free to conjecture that the "reasoning thing" behind the unreasoning mask is the reflection of his own malign intent, and the conjecture is certainly reinforced by the frequent equations of the hunter and the hunted: Stubb's dream of Ahab with a humped back as well as white 
leg (p.I77); Ahab's own rallying cry, "he heaps me" (p.22I), and his later complaint of being "humped" with weariness (p.684). It would be a naive reader who supposed the evil that Ahab wars on in the whale divorceable from his own demonic energies. The lie to a view of Ahab as St George taking on the dragon is given, in any case, by the stress Melville places on his hero's self-laceration.

The monomania around which Ahab assembles his factitious identity represents an assault upon the world in general, concentrated though it is upon a particular whale, and out of this enmity he manufactures his object of terror. For Ishmael, however, as Melville goes to some pains to demonstrate, Moby Dick comprises an entirely contrary if equaliy bleak set of resonances that are summed up in the fact of whiteness ( $p .253)$. Chief among these is the feature that Ishmael comes to last in his anatomy of the "colorless, all-color": the notion that the albino stands in relation to type as do the primary qualities of an object to its secondary, subjectively assumed ones:

consider that other theory of the natural philosophers, that all other earthly hues - every stately or lovely emblazoning - the sweet tinges of sunset skies and woods; yea, and the gilded velvets of butterflies, and the butterfly cheeks of young girla; all these are but subtile deceits, not actually inherent in substances, but only laid on from without; so that all deified Nature actually paints like the harlot, whose allurements cover nothing but the charnel-house within; and when we proceed further, and consider that the mystical cosmetic which produces every one of her hues, the great principle of light, for ever remains white or colorless in itself, and if operating without medium upon matter, would touch all objects, even tulips and roses, with its own blank tinge pondering all this, the palsied universe lies before us a leper... 
Ishmael's ultinate horror is of a universe which, once peeled of the aspects imparted by the observer, proves inert and blank, impossible, in the last analysis, to assimilate. Because his instinct is to reach out and incorporate the external world, be is stunned by the prospect of an opaque ego. His quest continues to be fuelled, nevertheless, by his hunch that "certain signjficance lurks in all things" (p.549).

Ahab needs no such assurance, for he asks no more of his world than that it throw back his image. Gazing at the golden doubloon, which will eventually go to him as the first member of the crew to sight Moby Dick, he is delighted to read, written small in each of its emblems, an allegory of his own grandeur and strength, a discovery that leads him to reflect:

that, too, is Ahab; all are Ahab; and this round gold is but the image of the rounder globe, which, like a magician's glass, to each and every man in turn but mirrors back his own mysterious self. $(\mathrm{p} .55 \mathrm{I})$

While Ishmal continues to be haunted by the featureless and unknowable, whether in the shape of a gigantic squid without "perceptible face or front" (p.366), the eyeless forehead of that "hooded phantom" the sperm whale itself (pp.30,486), or death or other of the enigmas which he wreathes in cancelled adjectives ("untried", "unshored", "unneared" etc., p.6I7), he remains as eager to overcome separateness as he is swift to detect it. "I an quick to perceive a horror, and could still be social with it", he confesses in the first sketch of his character (p.30). Ahab, on the other hand, looks to the external world only for 
confirmation of the identity he has created by fiat. Not for his eyes are the strange hieroglyphics that craze the skin of whales (pp. 399-400); and when he does catch sight of the arcana tattooed on Queequeg's body, the secrets of which will be sealed forever on his death, he turns away immediately harking back to his leitmotif, "Oh, devilish tantalization of the gods!" (p.6I2).

Melville portrays Ishmael and Ahab in opposition, but both figures, together with the quests they represent, are founded in Romantic individualism. Ahab's assault on Moby Dick manifests his rebellion against a hostile and repressive order; Ishmael's pursuit of the whale is the token of his determination to embrace a reality too daunting to be contained by man in his social aspect:

unless you own the whale, you are but a provincial and sentimentalist in Truth. But clear Truth is a thing for salamander giants only to encounter; how small the chances for the provincials then? What befel the weakling youth lifting the dread goddess's veil at Sais?

In keeping with this conceit of himself Ishmael associates the "slavish shore" with delusion, the "intrepid effort" exacted of the independent mind with the open sea (p.I49). When Ahab protests against procrustean pressures it is to insist rather on the stature sacrifice has brought him:

Starbuck is Stubb reversed, and Stubb is Starbuck; and ye two are all mankind; and Ahab stands alone among the millions of the peopled earth, nor gods nor men his neighbours! Cold, cold - I shiver! 
Solitariness is for then both a necessary condition whether of insight or self-exaltation, and it is to assert their singleness that they each selectively draw on the imagery of exploration. This use of exploratory metaphor appears, indeed, to be particularly characteristic of Romantic literature. Since for the Augustans the truths that matter most are those that endure and remain available to common understanding, the explorer typically serves in their fiction as a distant observer who can reflect with relative impartiality on his home culture or, through his encounter with alien people, isolate what is least accidental in human nature. For the Romantics, however, the idea of exploration holds a largely contrary set of significances. It is, for exanple, precisely the disparity between vision and common sense ("the spontaneous consciousness natural to all reflecting beings") that Coleridge, in a famous chapter from Biographia Literaria, chooses to translate into spatial terms:

The first range of hills, that encircles the scanty vale of human life is the horizon for the majority of its inhabitants. On its ridges the common sun is born and departs. From them the stars rise, and touching them they vanish. 20

So far the topology is that of Rasselas, but instead of turning to the world that lies beyond the mountains, Coleridge fixes on a realm far above the heads of the "multitude below": cloud-begirt ascents and undiscovered springs "which few have courage or curiosity to penetrate" make up the territory proper to the philosopher-poet. Coleridge's extended metaphor belongs to the start of a nineteenth-century tradition whioh associates remote and inhospitable regions with the search for truth. In writers as diverse as Browning, Ibsen, Olive Schreiner and 
Nietzsche the tradition remains current and seems to pass into irony only with Virginia Woolf's mock-heroic presentation of Mr Ramsay's quest for $Z{ }^{2 I}$ The passage from Biographia - a work that Melville acquired in I848 - would certainly have played its part in entrenching a common literary resource. 22

Melville champions intransigence in Moby Dick, but by no means uncritically. He counts the cost of Ahab's commitment to an absolute by disinterring, from time to time, the qualities that have fallen prey to his monomania. He relies, too, on the contrast offered by Ishmael who, since his quest for truth is founded in the urge to assimilate, continually seeks to overcome the separateness which nourishes the hero of his narrative. In short, Ahab's exclusivity is challenged throughout by the celebration of sympathy; and it is here that Melville reveals an important debt to Coleridge whom he singles out not as philosopher or critic, but as a poet of "noble merit" (p.256). This influence first becomes apparent when Ahab, lamenting the loss of his organic attachment to nature in a chapter entitled "Sunset", provides what amounts - if we allow for a little dramatic emphasis - to a brief precis of "Dejection: An Ode":

Oh: time was, when as the surrise nobly spurred me, so the sunset soothed. No more. This lovely light, it lights not me; all loveliness is anguish to me, since I can ne'er enjoy. Gifted with the high perception, I lack the low, enjoying power; damned, most subtly and most malignantly! damned in the midst of Paradise! (p.226)

Not only does Ahab present himself as failing to respond to the beauty 
of the external, twilit scene but he blames his failure on an intellectual sophistication that has choked his spontaneous being, on something comparable to the "abstruse research" that has suspended the poet's "shaping spirit of Imagination". 23

It is to The Ancient Mariner, however, the work in which Coleridge most insistently probes the sacrifices entailed by isolation, that Melville looks for a model of his central thematic conflict. The "wild Rhyme" comes up in connection with the albatross that Ishmael introduces into his catalogue of white things - here the bird has a function quite independent of the poem serving, like the white whale, as an emblem of an unnearable reality that entices and overawes (p.255). But later, as we shall see, Melville uses the symbol very much as Coleridge does. So many wild readings have attached to Coleridge's bird that one half expects to see "shooting albatross" glossed as eighteenth-century slang for taking heroin, but in fact its significance is quite firmly defined by the context of the poem. Not until it appears are the crew of the ice-bound boat relieved of their morbid fears and the isolation that besets them:

And through the drifts the snowy clifts

Did send a dismal sheen:

Nor shapes of men nor beasts we ken -

The ice was all between.

The ice was here, the ice was there,

The ice was all around:

It cracked and growled, and roared and howled, Like noises in a swound! 
Onto the setting the mariners project their terror of the beasts that are nowhere to be seen, and through some deftly implied sense distortion Coleridge renders their isolation individual as well as corporate; for the actual sound of the ice, a harsh cracking, is fed into the echo-chamber of a single swooning consciousness where it emerges ever less distinct and yet more menacing: consonants are increasingly muffled while verbs grow more predatory in the progression, "cracked and growled, and roared and howled". At this point the albatross gently materializes and to such effect that it not only requickens the mariners' instincts for cheer and companionship, welcomed, as it is, as a fellow soul and treated as a guest,

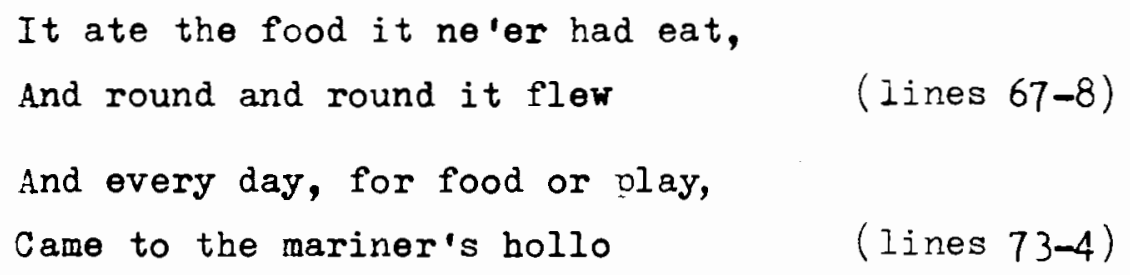

but also succeeds in forging a link with the blanked-out universe that lies beyond the ice as surely as moonbeams penetrate the fog,

$$
\begin{aligned}
& \text { Whiles all the night, through fog-smoke white, } \\
& \text { Glimmered the white Moon-shine. (lines 77-8) }
\end{aligned}
$$

In killing the bird the Mariner destroys the spirit that enkindles both the exuberant departure of the ship and the marriage feast (the two are spliced together at the poem's start) and in its place he reinstates the self-enclosing "land of mist and snow" (line I34), a spirit from which proceeds to dog the voyage.

It seems, at any rate, to have been a reading along these lines 
that led Melville, not long after his allusion to The Ancient Mariner, to introduce the chapter headed "The Albatross" in which, while presenting the Pequod's first contact with a passing boat, he develops a related conjunction of themes. Ishmael reports how at the mere mention of Moby Dick all attempts to communicate across the intervening stretch of sea founder. The ships are mysteriously drawn apart and the Captain of the Goney (or Albatross ) drops his speaking-tube into the water. This idea of cancelled relationship is pursued in the next chapter, "The Gam", where we learn that Ahab's obsession has caused him to forego the custom in wide practice among whaling crews of exchanging places and news on a chance meeting. The positive emphasis given to the "gam" is telling:

For not only would [the crew] meet with all the sympathies of sailors, but likewise with all the peculiar congenialities arising from a common pursuit and mutually shared privations and perils. (p.3I8)

Ahab is prepared to delay for no longer than it takes to acquire the "information be so absorbingly sought" ( $\mathrm{p} .317$ ). In cutting across the cordial institution - from which Melville generalizes to all instincts for "friendly and sociable contact" - he as good as kills the albatross.

Like Robinson Crusoe Coleridge's poem is the offspring of a marriage between spiritual autobiography and the travel book. The Mariner's progress from impiety to penitence and regeneration illustrates the lesson he impresses on the Wedding-Guest towards the closes 
'He prayeth well, who loveth well

Both man and bird and beast.'

$11.612-13$

Looked at fron this angle the poen unfolds, as Robert Penn Warren pointed out, a moral fable that represents the notion of "the one life", so central to the "conversation poems". 25 Though hardly just, it is at least appropriate that the Mariner, in view of the rejection of nature's accord implicit in his violent act, should experience the extremes of ostracism and self-imprisonment; appropriate too that a gesture of pure generosity towards creation, his blessing of the water-snakes, should restore him to grace. The fable, however, is patently at odds with the poem's universe. Coleridge himself called attention to the monstrous disproportion between the Mariner's suffering and his crime; and it is clear that the "one life" is celebrated in the poem as a myth in defiance of an absurd world rather than as an item of belief. 26 For this reason it would seem, the Wedding-Guest, after attending to the moral that gave rise to "All Things Bright and Beautiful", takes his leave sadder and forlorn; and the Mariner himself, despite his regeneration, remains a haunted and deracinated being, passing "like night, from land to land" (Iine 586), easily mistaken for one of the dead even while he speaks:

\section{I fear thee, ancient Mariner:}

I fear thy skinny hand:

And thou art long, and lank, and brown, As is the ribbed sea-sand.

When Melville borrows this image to describe Ahab at the instant he begins his chase, an instant darkened by a recognition of what his vengeance will entail, he draws on a Mariner whose curse remains 
irremoveable:

when all these conceits had passed through his brain, Ahab's brow was left gaunt and ribbed, like the black sand beach after some stormy tide has been gnawing it, without being able to drag the firm thing from its place.

Melville's debts to the poem are, in fact, manifold. His description of foam-flakes ( $p .3 I I)$, blinded eyes ( $p .46 I$ ), of a tongue-tied, painted crew(p.3I3), or of the skeletal Delight ( $p .679)$, are all steeped in Coleridge's vivid imagery, while the machinery of the "wild Rhyme" particularly the use of well-attested phenomena for supernatural effect - proves equally invasive. More important, however, is the way the poen provides an index to the exploration of Ahab's offence against the precept of living in the all.

In the course of its exactly scheduled passage the Pequod crosses the path of many ships, and on more than one occasion the crew have cause to cast back "lingering glances" ( $p .528)$; but it is on meeting the Rachel that Ahab's violation of the gam is really made to tell. The boat's name recalls the prophecy of Herod's massacre of the innocents (p.67I), and with reason, for it is with "iciness" that Ahab refuses the Captain's request that he join the search for his missing twelve-year old boy, and the soene raises not only the spectre of the son and newly-wedded wife whom he has already, in effect, "widowed" by leaving behind forever ( 0.683 ), but also the fate callously meted out to Pip. Indeed Stubb, the hard-headed mate who has refused to rescue Pip a second time from the ocean, in case be should lose a whale, provides the measure of his Captain's ruthlessness when he protests againgt the 
decision to turn a deaf ear to the Rachel's plea.

That Melville can register so severe an appraisal without surrendering Ahab's claims to sympathy is largely owing to the way he succeeds in suggesting the intensity of his hero's distress. The contrast between the Captain's "Grand-Lama-like exclusiveness" ( $p .59 I$ ) and the capacity for social merging that Ishmael exemplifies in his "marriage" with Queequeg and later voices in his rhapsody at the try-works (pp.84,532), runs through Ahab's character itself and assumes, little b. little, the form of a rift in the human psyche. Ishmael who begins and ends his narrative by presenting himself as an outsider, and most movingly recalls his childhood terror of isolation ( $p .33)$, is only too well acquainted with the state to which Ahab aspires. His yearnings for union ("let us all squeeze ourselves into each other", p.533) are based on his knowledge of separateness, as he himself indicates on overcoming his recoil from the "soothing savage":

I began to be sensible of strange feelings. I felt a melting in me. No more my splintered heart and maddened hand were turned against the wolfish world.

Ahab, conversely, gradually admits to the sociable nature that he keeps for the most part suppressed, even if his adnission sometimes takes the form of cursing "mortal inter-indebtedness" ( $p .601$ ). Shortly before the chase begins in earnest he experiences a sensation of kinship with his setting characteristic of Ishmael, and to mark his access of feeling, after dropping a tear into the ocean, sums up the Iife he has spent on deck: 
the desolation of solitude it has been; the masoned, walled-town of a Captain's exclusiveness, which admits but small entrance to any sympathy from the green country without. (p.683)

The small outlet represents, for the present, the Ishmael-like relationship he has formed with the crazed Pip from whom he is able to "suck most wondrous philosophies" (p.667). But the "cords" and "heart-strings" ( 0.659 ) by which Ahab feels himself attached will prove as destructive to the boy as the harpoon line which has twice dragged him into the sea; his plight is clearly linked with that of newly-born whales unlucky enough to fall into the path of a harpooner:

Starbuck saw long coils of the umbilical cord of Madame Leviathan, by which the young cub seemed still tethered to its dam. Not seldom in the rapid vicissitudes of the chase, this natural line, with the maternal end loose, becomes entangled with the hempen one, so that the cub is thereby trapped. $(p .498)$

Generation and bonding are often used in Moby Dick to epitomize the relational but this last brutal image is gुiven a particular poychological resonance in context, for Ishmael, in describing an assault upon a school of breeding whales, associates the sight of calves gathered in an "innermost fold" - where they suckle safely in transparent water at a great depth - with what he identifies as a centre of serenity within himself:

And thus, though surrounded by circle upon circle of consternations and affrights, did these inscrutable creatures at the centre freely and fearlessly indulge in all peaceful concernments; yea, serenely revelled in dalliance and delight. But even so, amid 
the tornadoed Atlantic of my being, do I myself still for ever centrally disport in mute calm.

The logic of this metaphor provides for the further sense that what is practised upon whales is practised upon the self, and accordingly supplies a rationale for the many images of self-inflicted violence that crowd the text. Thus it is that Ahab's "eternal, living principle" is devoured by his willed identity, by the "very creature he creates" (p.272), or that Starbuck warns in vain, "Ahab beware of Ahab" ( 0.605$)$. On the theme of self-immolation Ishmael extemporizes for two chapters at a time, skipoing from whales cooked by their own light and calf-heads eaten by "bucks", to letters on the suppression of cruelty to ganders written with quills, till he comes to rest on cannibalism among fish (pp.392-6). He flirts, too, with a rhetoric of self-cancellation with "endless ends", and "uncatastrophied fifth-acts" (pp.606,6I6); and delights in tail-in-mouth constructions:

\section{both chasing and being chased ( $\mathrm{p} .49 \mathrm{I}$ )}

Is heaven a murderer when its lightning strikes a would-be murderer? (p.65I) yesterday I wrecked [the compass which today] would feign have wrecked me (p.655)

Who's to doom, when the judge himself is dragged to the bar? (

Ishmael sees Ahab's signature everywhere, and the generalizing habit is particularly appropriate to a narrator whose most distinctive trait is the urge to dilate. The contrary tendency appears in Ahab whose "ever-contracting, dropping circle ashore" (p.592) typifies a process of concentration that is both bodily and mental. Into the straits of a narrowing resolve his energies flow "deepeningly contracted" after 
his accident ( $p .248)$, and so fretted is he with purpose that by the time of the chase he has grown humped and bowed as well as haggard (p.684). Melville repeatedly describes Ahab as eaten into by his obsession, and the metaphor is kept alive by the limb made of polished jawbone that seizes its chance, on one occasion, to tear at his flesh $(p p \cdot 590,592)$. As the voyage progresses we pick up the clues which show Ahab increasingly mastered, for all his boasted freedom, by the object of his hatred: he surrounds himself with ivory accoutrements, screws into the deck; and, manifest in Fedallah, his evil genius goes down at last pinned to the back of the whale.

Ishmael finds a source of serenity at the centre of his being; how, then, are we to regard the war Ahab makes on his world? In Typee Melville celebrates the natural innocence of the South Sea islanders and identifies aggression as a symptom of life in the West; in Moby Dick, however, it is the behaviour of $\mathrm{Ahab}$ and his men that he offers as a token of the natural forces that mufle the surfaces of civility:

Long exile from Christendom and civilization inevitably restores a man to that condition in which God placed him, i.e. what is called savagery. Your true whale-hunter is as much a savage as an Iroquois. I myself am a savage, owning no allegiance but to the King of the Cannibals; and ready at any moment to rebel against him.

Important among the other savages that Ishmael enlists in his undercover inquiry into human nature are the sperm whales; and the variety of impulse they display is as mixed as the conduct of the Pequod's crew. In a whole school there is equal evidence of pugnacity and delight, and 
in describing sexual jealousy among the bulls, Ishmael comes close to suggesting that intensities are matched at either extreme:

\begin{abstract}
As ashore, the ladies often cause the most terrible duels among their rival admirers; just so with the whales, who sometimes come to deadly battle, and all for love.

The idea that antinomies are natural and necessary is developed further in the account of the whale cemetery in the Arsacides where the sight of vines clinging to the huge skeletons for support triggers off the reflection: "Life folded Death; Death trellised Life; the grim god wived with youthful Life, and begat him curly-headed glories" (p.574). The motif of "warp and woof intermized" is sounded earlier in the famous passage evoking the vision of the drowning Pip, and there again the emphasis fells on the ambivalence of creation: the "unwarped primal world" is at once both "joyous" and "heartless" (p.530). By way of a closing emblem Melville has Ishmael make a lifeboat of the coffin of his friend.

"The King of Cannibals" has many counterparts in nature, but even the self-destruction that seems a consequence of wilful perversion is paralleled by a creature of the deeps. Nhile queequeg murders the sharks, the sharks murder each other but also themselves:

They viciously snapped, not only at each other's disembowelments, but like flexible bows, bent round, and bit their own; till those entrails seemed swallowed over and over again by the same mouth, to be oppositely voided by the gaping wound.

Ahab belongs to a world in which even the instinct of self-preservation 
is blind.

When the Ancient Mariner imparts his final lesson he endorses his hymn of praise to the "one life" by invo'sing a divinely ordained creation:

\footnotetext{
'He prayeth best, who loveth best

All things both great and small;

For the dear God who loveth us,

Ee made and loveth all.'
}

(lines 6I4-I7)

Moby Dick which Melville described to Hawthorne as "a wicked book" hints at a darker genesis. ${ }^{27}$ Whaling men, whales, the underworld of the sea, even the Orient revive in varying degree "the ghostly aboriginalness of earth's primal generations" (. .308$)$; but in the chapter on whale fossils Ishmael is taken back still further - "to that wondrous period, ere time itself can be said to have begun; for time began with man" (p.582). Nriting almost a decade before The Origin of Species (I859) Melville wryly extrapolates from the traditional biblical landmarks on venturing beyond the human realm. We are reminded that the whale survived the Flood without the help of Noah, the ice age too $(p p .589,582)$; and that a recently unearthed skeleton, thought in Alabama to be that of a fallen angel, belonged in fact to an ancestor of the modern whale, to "one of the most extraordinary creatures which the mutations of the globe have blotted out of existence" (p.582). Against Leviathan, Melville counterpoints Zeuglodon; but where Job is convinced by his monster of an omnipotent, controlling presence, Ishmael is merely thrown back on his feelings of awe: 
I am horror-struck at this antemosaic, unsourced existence of the unspeakable terrors of the whale, which, having been before all time, must needs exist after all humane ages are over.

An explorer to the end, Melville deferred to no system. A fullyfledged theory of evolution was still to appear, but he shows himself familiar with the two chief components that went into its making. Through his scientific reading he was well acquainted with the notion of mutation among the species; and from his remarkable description, in The Encantadas, of the huge tortoises of the Galapagos - perhaps the very ones that stimulated Dawin's account of a modifying environment - it is clear that he had pondered deeply on the struggle for survival. 29 He presents the giants as emblems of "indefinite endurance", himself as a paleontologist pouring over the rockface of their battered shells, each fissure and abrasion capable of disclosing untold secrets of descent. Less fancifully, he comments on the creature's habit of engaging in headlong conflict with every obstacle in its path:

Their stupidity or their resolution was so great, that they never went aside for any impediment ... At sunrise I found [one] butted like a battering-ram arainst the immovable foot of the foremast, and still striving, tooth and nail, to force the impossible passage. 30

This is Ahab all over. The "all feeling" which counteracts his implacable drive was still to regain a sanction from nature, and would do so only once a clearer picture emerged of the way the diverse species joined in a common ancestry. For Melville, however, the suspicion of flummery was not enough to cut off a valuable resource. 
Conrad Dismantles Providence:

Deserted idylls in An Outcast of the Islands

With the grim sequel to his present misfortunes already told in Conrad's first novel, a half-disillusioned Almayer at the close of An Outcast of the Islands (I896) vents his disappointment by rounding on the universe,

Where's your Providence? Where's the good for anybody in all this? The world's a swindle! A swindle!

The abuse he hurls at the heavens is checked at length by a stammered reply:

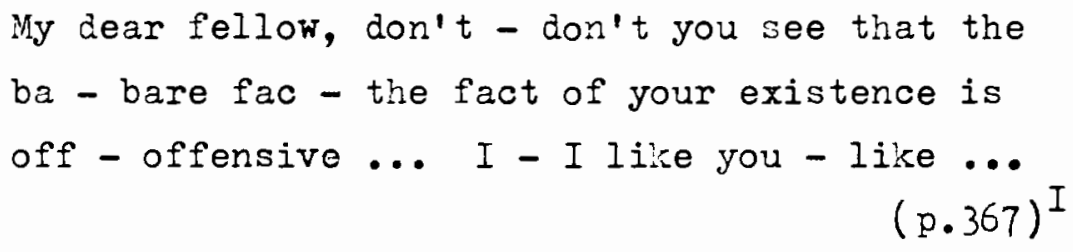

The speaker is a dying naturalist specially brought in for the novel's coda, and he punctures the "quarrel with Providence" by insisting on Almayer's part in the order be vilifies. His enigmatic words trail into silence, but the trappings of his profession combine with details of the tropical setting (insects stream into a smoking flame) to impart a strong evolutionary bias to his utterance. The decisive gloss to his remark comes in Falk (I903) when Conrad characterizes his man-eating hero, almost 
an emblem of the will to strive, as a creature who perpetually gives "cause for offence". 2

While the ending of An Outcast of the Islands highlights a pervasive concern with the loss of order and exhibits the tonal range of a narrator who moves between pathos and resilient irony, it also makes a claim to a wider relevance than attaches to the novel's colonial themes. ${ }^{3}$ Through it Conrad relates his local portraiture to a metaphysical issue which he took to be of overriding importance to his age: he belonged, after all, as Ian Watt has recently suggested, to the first generation who had pressing reason to doubt "the traditional view of man's flattering eminence in the history, as well as the design, of the cosmos". 4 He was haunted, as has frequently been pointed out, by the vision of a lost buman significance. Many passages from his correspondence fill out the often cited declaration from A Personal Record, "I have come to suspect that the aim of creation cannot be ethical at all". 5 Under the influence of astrophysics as well as the life sciences Conrad entertained a "severely scientific" view of the universe which set moral constructions at nought. 6 The contrast between the halo of conviction surrounding human activity and the dismal truth prescribed by the cold light of reason fascinated him, and he often images a chaos opening up beyond the shifting mists of illusion as in this representative extract from his letters to Cunninghame Graham: 
of course reason is hateful - but why? Because it demonstrates (to those who have the courage) that we, living, are out of life - utterly out of it. The mysteries of a universe made of drops of fire and clods of aud do not concern us in the least. The fate of a humanity condemned ultimately to perish from cold is not worth troubling about. If you take it to heart it becomes an unendurable tragedy. If you believe in improvement you must weep, for tho attained perfection must end in cold, darkness and silence ... Faith is a myth and beliefs shift like mists on the shore; thoughts vanish; words, once pronounced, die; and the memory of yesterday is as shadowy as the hope of to-morrow. 7

The bearing of these ideas on Conrad's first novels has not, I believe, been fully brought home. Recurrent themes such as patronage, imprisonment and projection, which have come in for separate treatment (and of ten been taken as disjunct), revolve in context round a concern with the disappearance of a rational order transcending the self. 8

In both Almayer's Folly (I895) and in Outcast of the Islands (I896) Conrad foregrounds the collapse of various personal fictions and in doing so invokes the breakdown of wider systems of belief. When Almayer learns that his lifelong dream of returning, rich, to Europe with his daughter has never coincided with his daughter's wishes he finds the "whole universe unsettled and shairen". in earlier moment of truth, the foundering of his commercial prospects at Sambir, inspires the outburst that closes An Outcast. In the case of Almayer's 
patron, Tom Lingard, who succeeds in reallzing his fantasies to the extent of presiding as an "Arcadian" law-giver over a river that he has grown to regard as his own, It is the betrayel of willems, his other protégé, that precipitates the profound insight into chaos that his sense of decency proves powerless to dispel:

\begin{abstract}
there remained nothing but the sense of some immense infamy - of something vague, disgusting and terrible, which seemed to surround him on all sides ... Was there, under heaven, such thing as justice? He looked at the man before him with such an intensity of prolonged glance that be seemed to see right through him, that at last he saw but a floating and unsteady mist in human shape. Would it blow away before the first breath of the breeze and leave nothing behind?
\end{abstract} $(p .265)$

Conrad's words to Cunninghame Graham are recalled by the imagery here as they are by an earlier comment on Lingard's glimpse of a reality beyond the "limits of the universe strictly defined by those we know":

There is nothing for us outside the babble of praise and blame on familiar lips, and beyond our last acquaintance there lies only a vest chaos; a chaos of laughter and tears which concerns us not; laughter and tears unpleasant, wicked, morbid, contemptible - because heard imperfectly by ears rebellious to strange sounds. (p.I98) 
The pattern persists. Babalatchi, the sly counsellor who engineers the Arab take-over of Sambir, briefly surrenders to the same vision on receiving news of Omar's death, but the bitter ory that rises to his lips, "as profound as any ph1losophicel shriek", is muffled by his triumph and he turns once more into "the puller of wires" (p.2I5).

Against this varied range of orises there stand out the two failures of trust that make up the story of the novel's central figure, the outcast himself. Before he brings min on himself by taking money off his employer, Willems revels in his prospects of success. The adulation of his wife and her half-caste family feed his self-esteem, but he rejoices chiefly in the promise of a trading career that will sweep him onward to the bright if hazy "goal of his ambition" (p.II). He is jolted out of his life of acquisition, however, when Hudig sacks him for "borrowing" money without permission, and a shame bred of his enormous pride instantly eats away the fabric of his social presence:

For the first time in his life he felt afraid of the future, because he had lost his faith, the faith in his own success.

He sees himself stripped of past and future, a naked being recoiling from "the presence of unknown and terrible dangers".

Conrad dramatizes this climax in his hero's existenoe by introducing a scene that holds the key to much of the novel's 
symbolic action. After falling out with his family willems takes to his heels until he finds himself at last in the dark beyond the outskirts of the coastal settlement. Escape from "the temple of self and the concentration of personal thought" is associated with his movement into the wilderness:

it seemed to him that the world was bigger, the night more vast and more black ... he went on doggedly with his head down as if pushing his way through some thick brambles.

$(\mathrm{pp} \cdot 30-\mathrm{I})$

The metaphor of departure from the straight and narrow path, sounded in the first sentence and continually returned to, orchestrates an underlying identity between the jungle and the uncovenanted life into which Willems is ejected by his transgression. In Almayer's Folly the image of terra incognita is applied to the discovery of passion: shortly before her elopement with Dain, Nina (aptly named after Columbus's vessel) roundly tells her father: We entered a land where no one could follow us, and least of all you. Then I began to live. ${ }^{\text {IO }}$

Exploratory imagery in An Outcast carries darker associations - the hinterland of Borneo is more often equated here with absence than with recovery.

Though Willems is apparently rescued from his plight by Captain Lingard who shows hin the secret entrance to his river and leaves him upstream in the company of Almayer, his disorientated condition 
now finds a correlate in a region that Conrad was later to describe as "one of the lost, forgotten, unknown places of the earth". II It is this setting that Willems undergoes his second and more poignant reversal of fortune. He falls for Aissa, the beautiful daughter of Omar, who returns his love. In the heart of the jungle a realm of enchantment opens for them both, but even as Willems seems set to launch himself on a life that holds truer riches than his previous career, he suffers a loss of nerve. Aware that he has scant resources to balance against his dependence on Aissa, he struggles against total surrender clinging pathetically to his old, threadbare self. Without escaping the antagonism and betrayal entailed by his devotion he finds his love poisoned at source. But the charged ironies of his situation lead to insight. At the moment that he sidesteps the murderous kriss wielded by Aissa's father he looks beyond the immediate context of his vexed affairs to perceive a world ridden with conflict and doubt:

It was the unreasoning fear of this glimpse into the unknown things, into those motives, impulses, desires he had ignored, but that had lived in the breasts of despised men, close by his side, and were revealed to him for a second, to be hidden again behind the black mists of doubt and deception. It was not death that frightened him: it was the horror of bewildered life where he could understand nothing and nobody round him; where he could guide, control, comprehend nothing and no one not even himself.

A failure of serenity robs willems of both his old identity and his new. Piloting Abdullah's men up the secret channel, he plays the key 
role in ousting his patron at Sambir, and one consequence of his betrayal is that his hatred of Aissa grows. Reviling the images of his lost life $(\mathrm{pr} .338-9)$ and cursing himself at the same time for his newfound desire, he ends as his own worst enemy and, sensing this, Lingard abandons him to his own devices on the upver reaches of the river. There until his violent death he and Aissa endure a tormented state of mutual isolation - "each the centre of dissimilar and distant horizons; standing each on a different earth, under a distant sky" (p.334). Although he has cherished the dream of a shared retreat -

his face brightened with the soft light of dreamy enthusiasm ... he looked like some ascetic dweller in a wilderness, finding the reward of a self-denying life in a vision of dazzling glory ...

'And then I would have her all to myself away from her people - all to myself - under my own influence - to fashion to mould - to adore - to soften - to ... Oh! Delight! And then - then go away to some distant place where, far from all she knew, I would be all the world to her!

Willems finds at last that Aissa and be each constitute their own "deserted island". I2

Conrad undermines his characters in order to expose the flawed status of their belief; and the pattern of a willed or received order crumbling under the impact of a sinister reality, or the related coupling of ordinary experience with some darker counterpart, recurs with particular persistence in the early work. That his concern with a changing world view, manifest in his repeated portrayals of blighted 
hope, should emerge with particular clarity from his second novel has to do, perhaps, with a subtle inversion of his readers' expectations there. Much in An Outcast of the Islands suggests a deliberate disaffiliation from the desert-island-idyll set in Eastern seas: the novel's title, its lavish but ambivalent response to an exotic setting, its sustained metaphors of exploration and of the castaway were sure to summon associations mostly of a contrastive kind. Likening the book to Melville's Typee (I346) for its "scenic descriptions of tropical islands" a contemporary reviewer went on to prepare his readers for a "ruined paradise". I3 "I didn't find there what I am looking for when I open a book", Conrad in his turn once curtly remarked of Typee and Omoo; ${ }^{I 4}$ but, of course, for many readers it was Conrad's pessimism that proved an insurmountable bar. "Even genius", wrote a critic in the spectator, "will not win forgiveness for the repulsive cynicism of the dialogue between Almayer and the Professor in the last chapter."I5 Iike the botanist's "bare fact of existence" the evolutionary perspective introduced in the coda gave cause for offence.

There can be little doubt that such responses were foreseen. Conrad supplies one pointer in the novel when he closes a chapter with the sketch of a jaundiced tale, sung over again by the crafty Babalatchi, stage-manager of the coup d'état at Sambir:

It had all the imperfections of unskilful improvisation and its subject was gruesome. It told a tale of shipwreck and of thirst, and of one brother killing another for the sake of a gourd of water. A repulsive story which might have had a purpose but possessed no moral whatever. 
There is a distinction, to be sure, between Conrad's art and that of the one-eyed singer, but the eerie dithyramb does darkly mirror the action of the novel and characterize its tenor. The struggle between the castaway brothers prefigures the rivalry (fomented by Babalatchi) that is to set Almayer and ililems - "brothers" in the eyes of their honorary father, Iingard - at each other's throats. The notion, too, of murder in the place of expected sanctuary parallels the many homicidal fantasies and acts that stud the idle hours spent along the river's uncrowded banks. Willem's death to take a single instance - is contemplated by six characters before Aissa blasts him through the chest. I6 In lieu of a privileged glimpse into the prelapsarian state Conrad presents characters in the throes of internecine violence. Even his image of the rescued castaway is dextrously emptied of solace:

Those three human beings abandoned by all were like shipwrecked people left on an insecure and slippery ledge by the retiring tide of an angry sea - listening to its distant roar, living anguished between the menace of its return and the hopeless horror of their solitude - in the midst of a tempest of passion, of regret, of disgust, of despair. $(p .328)$

Willems is by any reckoning an unpleasant man, but his story - like Babalatchi's cautionary tale - is given a general significance in line with the remark Conrad once made to Cunninghame Graham: "Abnegation self-sacrifice means something. Fraternity means nothing unless the Cain-Abel business. That's your true fraternity. Assez."I7

Much of the force of Conrad's polemio is lost unless we appreciate the context of the desert island genre. Foremost among countertypes 
An Outcast of the Islands relates to a book like Typee in much the same way that William Golding's Lord of the Flies (I954) relates to Coral Island (I857); and to Ballantyne's novel I propose now to turn since it provides an admirably clear paradigm of the kind.

In a critical work on fiction Barbara Hardy identifies a particular sort of novel in which a "single and simplified belief ... excludes much of the varied causality to be found in life", and as an example of such "dogmatic form" cites Robinson Crusoe, a text in which "action and characters are shaped by ... a special belief, the belief in Providence". It what holds for Defoe's first novel proves even truer of its much later descendant Coral Island, for Ballantyne plots the workings of Providence with the assiduity of an astrologer. A timely prayer accounts for the deliverance of Ralph and his two mates from the fate of the rest of the crew $(\mathrm{pp} .6, \mathrm{IO}) .{ }^{\text {I9 }}$ Supernatural influence can again be detected in Jack's single-handed victory over the bloodthirsty warriors as in Ralph's later escape from a cannibal horde ( $p p . I 47,20 I)$. When a sudden downpour saves the three boys from sentence of death, Providence can be said to kill two birds with one stone; for the tribesmen are so impressed by the timing and violence of the storm that they instantly embrace the Christian faith (pp.270, 274). Wile Ralph, like Crusoe, is brought closer to the devout life by his new setting $(p p . I 9,27)$, the island offers up images of a pristine world more consistently than does Defoe's. With an imagination unburdened by knowledge of the South Seas, Ballantyne purveys an "ancient Paradise" ( .24$)$ in all the aureate terms of pastoral and his brightly enamelled sketches come equipped with sententious mottoes: 
The sea was shining like a sheet of glass, yet heaving with the long deep swell that, all the world round, indicates the life of ocean; and the bright sea-weeds and the brilliant corals shone in the depths of that pellucid water, as we rowed over it, like rare and precious gems. Oh! it was a sight fitted to stir the soul of man to its profoundest depths, and, if he owned a heart at all, to lift that heart in adoration and gratitude to the great Creator of this magnificent and glorious universe.

( pp.II4-I5)

The recovery of the unfallen extends to the boys' relationship in which teasing absorbs the only traces of malice, so that the narrator can fairly reports

There was, indeed, no note of discord whatever in the symphony we played together on that sweet Coral Island; and I am now persuaded that this was owing to our having been all tuned to the same key, namely, that of love!

So persistent is the idyll that the reader has to be reminded that the islands are "very unlike Faradise in many things" before any action can be got under way (p.24). Beyond the charmed circle of the reef there lies a starkly variegated universe that seems to be the product of a dualistic creation. With such vehemence does Ballantyne denigrate his Melanesians (all his islanders are black) that every intrusion into their preserve appears as an advance for the cause of heaven. And even while the narretor insists on the horrors of the pagan world, the novel succeeds in suggesting that evil is accidental and temporary, devoid of proper standing in the normal universe. Pagan excesses (of a heotic sort) are placed on a par with natural disasters - the falling rock, the tidal wave, the menacing 
cry - those unexpected events that momentarily suspend the assurance of continuing order, and so interrupt, as Ralph puts it, the even tenor of their way (p.I38). The reader is lod to understand that when the boys act heroically they simply lend a hand to the properly benevolent processes of nature. Whenever they intervene it is on the assumption that they are merely fishing a spanner out of the works. Even at the height of the novel's violence Ballantyme presents perhaps with some Mozartian or Shakespearean reminiscence - an ocean wonderfully animated with benign intention:

With a savage laugh, the chief tore the child from her arms and tossed it into the sea. A low groan burst from Jack's lips as we witnessed this atrocious act and heard the mother's shriek, as she fell insensible on the sand. The rippling waves rolled the child on the beach, as if they refused to be a party in such a foul murder, and we could observe that the little one still lived. (p.I45)

Once he has quelled the preposterous chief, Jack - needless to say restores the baby to its mother, thus completing what nature, seemingly of its own accord, began. His little act of rescue looks forward to the novel's most extended episode, the deliverance of Avatea who is saved from a forced merriage and restored to her deserving lover.

To turn from Ballantyne's text to An Outcast is to move into a world that revokes all assurance of order. The change makes itself felt even in those descriptive passages that Conrad, for his part, over modestly called "mere scenery". 20 Where Ballantyne delights in the picturesque and - in so far as he aims at thematic ends - stresses the harmonious relationship between the natural objects that be selects, Conrad portrays a wilderness that supplies an immediate analogue to the 
human scene because of his fidelity to an overriding principle, the individual's struggle for life. This, at least, is a conspicuous feature of that "sense for the psychology of scene" which Edward Garnett singled out as Conrad's most distinctive contribution to the novel. 2I The gift was Conrad's from the start as the following passage from Almayer's Folly makes clear:

the big trees of the forest, lashed together with manifold bond by a mess of tangled creepers, looked down at the growing young life at their feet with the sombre resignation of giants that had lost faith in their strength. And in the midst of them the merciless creepers clung to the big trunks in cable-like coils, leaped from tree to tree, hung in thorny festoons from the lower boughs, and, sending slender tendrils on high to seek out the smallest branches, carried death to their victims in an exulting riot of silent destruction. 22

The passage follows on Almayer's discovery of his daughter's elopement with Dain, a discovery that shatters the dream that has sustained his life; but although the fate of the hapless trees vaguely foreshadows the decay that awaits Almayer, the scene does not so much conjure up a direct equivalence - our sympathies are, in fact, divided between Nina and her father - as illustrate the conception that in the natural world, at any rate, one creature prospers at the expense of another. When Ballantyne, on the other hand, describes the main valley of his island the scene he conveys, though an entirely uninhatited one, finds its focal point in man the movements of the narrator's eye are guided by utility and pleasure:

Some trees were dark glossy green, others of a rioh and warm hue, contrasting well with those of a pale light green, which 
170.

were everywhere abundant. Among these we recognised the broad dark heads of the bread-fruit, with its golden fruit; the pure, silvery foliage of the candle-nut, and several species which bore a strong resemblance to the pine; while here and there, in groups and in single trees, rose the tall forms of the cocoanut palms, spreading abroad, and waving their graceful plumes high above all the rest, as if they were a superior race of stately giants keeping guard over these luxuriant forests. Oh! it was a most enchanting scene, and I thanked God for having created such delightful spots for the use of man.

(pp.68-9)

Unlike Conrad's giants who at last face, themselves, the starvation on which their triumph depends, Ballantyne's tall and gracefully plumed palms live up to the responsibilities of senior standing with a stateliness that becomes superior rank. Their protectiveness represents one of many tokens of providential design. With its plentiful food, its natural breakwater and balmy air - surf on the distant reef tenders a lullaby to the boys as they settle to sleep under the stars - the island offers a blueprint of the unfallen place. Only once they have ventured out beyond the atoll do Ralph and Peterkin discover that they can no longer take for granted the structure of reliance on which their experience of the island has been founded. Then a sudden squall pounces on their makeshift boat, Ralph remarks:

Peterkin and I were so much in the habit of trusting everything to Jack that we had fallen into the way of not considering things, especially such things as were under Jack's care. ile had, therefore, never doubted for a moment that all was going well, so that it was with no little anxiety that we heard him. 
While Ballantyne is ready to admit that unbounded confidence can prove a liability in the fallen world, it is Jack's paternal care of his younger comrades that he is out to celebrate.

Providence is a variable concept, and for the most part a vague one. It tends to be most closely defined when consciousness of suffering or of free will is at a low ebb. It may be interoreted in terms chiefly of material or spiritual reward; it may be construed, again, as centred either on the life of the individual or of the race. Implied by all versions, however, is a sense of security stimulated by a faith in the ultimately ethical nature of the universe; which is to say that while Providence is a theological dogma it proposes itself more immediately as a state of mind, a resource of serenity, what the stoics knew as ataraxia. In Christian thought a range of differing tenets has been animated by the vivid figure of God the Father, a metaphor that goes back to the Sermon on the Mount and the Lord's Prayer. To the roles of creator and law-giver, this convention adds that notion of a solicitous parenthood commemorated in many nineteenth-century hymns. To quote from one example:

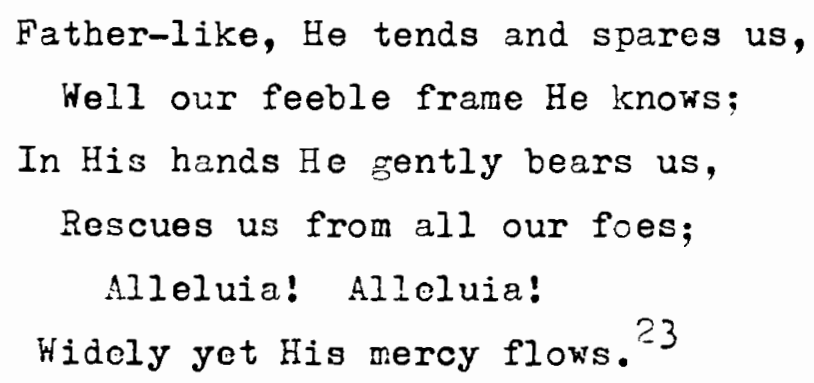

A cynic might have argued that Providence was no more than a 
feeling of familial security projected into the shy. Given the force and prevalence of the paternal analogy, it is not surprising that declining faith in a transcendent order should have called the entire issue of psychological dependence in question. This, at least, seems to have been the direction taken by Conrad's imagination when at the start of his career he examined a series of tutelary relationships that reflect the relation of God and devotee.

In his introductory note to An Outcast Conrad recalls that his interest in the person who suggested his hero was aroused chiefly by his "dependent position". 24 When we meet Willems, however, it is in the complementary role of a panjandrum presiding over the fawning submission of his Sirani wife and hangers-on. In the opening paragraph a srotesque brand of devotional language is applied to the homage that the odious Willems exacts from the $\mathrm{Da}$ Souza farily - "He loved to breathe the coarse incense they offered before the shrine of the successful white man" (p.4). This imagery gradually widens into an explicit metaphor of Nillems's God-like role:
he fed and clothed that shabby multitude; those degenerate descendants of Portuguese conquerors; he was their providence; he kept them singing his praises ... It is a fine thing to be a providence, and to be told so on every day of one's life. It gives one a feeling of enormously remote superiority, and inillems revelled in it. He did not analyse the state of his mind, but probably his greatest delight lay in the unexpressed but intimate conviction that, should he close his hand, all those admiring human beings would starre.
$(p p .4-5)$

The attitudes Hillems displays are the least attractive of many 
generated on the providential model in An Outcast. But while his assumptions of supremacy reduce those about him to ciphers - he associates his wife with the parrot and after she has served as an audience dismisses her with a contemptuous "Go to bed, dummy" (p.9) - the Da Souzas prove to be equally corrupted by their dependence on him:

His munificence had demoralized them. An easy task. Since he descended amongst them and married Joanna they had lost the little aptitude and strength for work they might have had to put forth under the stress of extreme necessity. They lived now by the grace of his will. This was power. Willems loved it.

The forces that enable the little anti-hero to "tyrannize good-humouredly" over his family are many and diverse - part of the irony lies in their sheer arbitrariness - but to Willems himself it appears that his dominant role flows from the "very nature of things", and as self-evidently, too, as light from the sun, or perfume from flowers ( $p \cdot 3)$.

In a world in which the institution of in loco parentis is taken as part of a rationally ordained scheme it is easy for Willems to find a natural sanction for his domestic set-up. Conrad's analysis of the actual relationships that underlie Willem's patriarchal cloak takes two main directions. It becomes clear in the first place that the social codes which ratify Willems's expression of absolute will leave him locked in sterlle self-absorption. In some fine commentary on this phase of the novel R. Roussel remarks 
on the self-love that condemns Willems to "a solipsistic world which makes an authentic life impossible". 25 Conrad's presentation here may well show the influence of Schopenhauer's key idea that egoism has the effect of insulating the individual from reality. 26 Despite the enormous challenge posed later by Aissa's beauty, Willems's career ends in a self-conceit as inviolable as that with which it began. He remains a man "possessed ... by the immovable conviction of his own importance, of an importanoe so indisputable and final that it clothes all his wishes, endeavours, and mistakes" (p.327). After he has rejected passion and with it the living world, he moves through a landsoape which his egoism has rendered barren:

Upon the faintly luminous background of the erstern sky, the sombre line of the great forests bounded that smooth sea of white vapours with an appearance of a fantastic and unattainable shore. He looked wi thout seeing anything - thinking of himself. Before his eyes the light of the rising sun burst above the forest with the suddenness of an explosion. He saw nothing. (pp.339-40)

When he does use his eyes the jungle merely returns an image of his morbid state:

Death everywhere - wherever one looks. He did not want to see the ants. He did not want to see anybody or anything. He sat in the darkness of his own making.

As he becomes increasingly self-enclosed he approaches the fate of those self-defeating egotists whom Schopenhauer memorably characterizes:

their knowledge remains subject to their will; they seek, therefore, in objects, only some relation to their will, and 
whenever they see anything that has no such relation, there sounds within them, like a ground bass in music, the constant inconsolable cry, "It is of no use to me;" thus in solitude the most beautiful surroundings have for them a desolate, dark, strange, and hostile appearance. 27

The Identity that Willems fashions for himself round the satisfaction of his greed - he marries Joanna only to ingratiate himself further with his employer - leads ineluctably, despite all the reversals and unexpected openings of his subsequent history, to a self-imposed condition of solitary confinement. Abetted by his authoritarian role, Willems ends as the prisoner of his will.

A second aspect of Willems's experience brought into focus by the metaphor of Providence at the novel'a start, is his assumption of racial superiority. Al though he prides himself on being free of all colour prejudice (p.35) Willems's sense of importance hinges on the respect he exacts from his mulatto family, and from his situation in the larger colonial contert. Willems, as Bruce Johnson shrewdly observes, is the kind of white man who "falls back on his role as sahib or tuen for all sense of identity, for authority, for moderate success - for all the things he would have to accomplish laboriously among his white peers". 28 The psychological consequences of Willems's racial patronage only become fully clear when his relationship with Aissa develops. Passion itself becomes equated in his mind with darkness, until from the ivory tower of his public identity he legislates against his own desires in the name of racial purity:

He was disappointed with himself. He seemed to be surrendering to a wild creature the unstained purity of his life, of his race, 
of his civilization.

"The eyes of a savage; of a damned mongrel, half-Arab, half-Malay. They hurt me! I am white! I swear to you I can't stand this! Take me away. I am white! All white!" (p.27I)

But if in playing God Willems loses his humanity, his creatures also undergo disfigurement. The moment he loses his job and is accordingly dislodged from his position of power, his self-effacing wife reveals an underside of festering rancour. Her eager denunciation of her husband betrays a tell-tale reversal of roles ( 0.27$)$ and her brother Da Souza who stands in wait for Willems with a rusty iron bar shows himself already entrenched in the vacated place of authority:

Do not hurt her, Mr Hillems. You are a savage. Not at all like we, whites. $(p .28)$

It is not long before he insinuates that his brother-in-law is a half-breed (p.29). Among settlers, race and status are so finely intermeshed that in growing assertive, Da Souza inks in his former icon and announces himself white.

While the providential imagery that Conrad applies to Willems is partly mock-hercic (his pretensions to stature are unerringly punctured), it serves also to underline the essentially irrational basis of his authority. It provides a means of articulating the aura so widely attaching to class or to racial dominance in the life and popular fiction of the period. Conrad is in company here with Kipling who, when he offers an "allegory of Empire" in a short story 
from Life's Handicap (I896), chooses as his central metaphor the all-providing Father. The treatment is characteristically sardonic for the more successful Naboth proves in easing a benevolent Jahib out of his goods, the more frequently he pleads his devout submission:

He said I was his father and his mother, and the direct descendant of all the gods in his Pantheon, besides controlling the destinies of the universe. 29

The same theme, from a very different approach, still informs Paul Scott's Indian tetralogy (I966-75) where the collapse of the Raj is presented in terms of a clash between hieratic and secular conceptions of power. ${ }^{30}$ When Conrad returns to this area of concern in Under western Eyes (I9II) he shows his young Russian hero struggling to retain a conservative liberalism in the face of Czarist nysticism on the right and a displaced Messianism on the left. For the ruthless President de P- the autocracy of the state is a reflection of an omnipotent God:

"the thought of liberty has never existed in the Act of the Creator ... revolt and disorder in a world created for obedience and stability is sin. It was not Reason but Authority which expressed the Divine Intention. God was the Autocrat of the Universe." $3 I$

For the more congenial Mikulin the status quo can be made the instrument of divinely inspired reform. History for the revolutionaries, on the other hand - despite their identification of the church with oppression - also unfolds a providential plan. 32 
Razumov's great temptation is to succumb to such a reading of events. "I have the greatest difficulty in saving myself from the superstition of an active Providence", he confides shortly before bis confession. 33 That he does finally succumb is further witness to the energies demanded of his independent vision. 34

In An Outcast it is about the figure of Tom Lingard that the treatment of Providence gathers to a head, and part of the reason for this is that the old Captain connects with the theme in two ways. Whereas Willems celebrates an amoral world, building his career on the maxim, "where there are scruples there can be no power", it is precisely firm principles that distinguish Lingard from the "unscrupulous, and noisy crowd" (pp.8,273). He upholds a clear-cut code of conduct; but, in addition to that, he is convinced that right doing naturally results in material success. His faith, as the narrator reminds us in a passage of extended commentary, is both simplo and pragmatic:

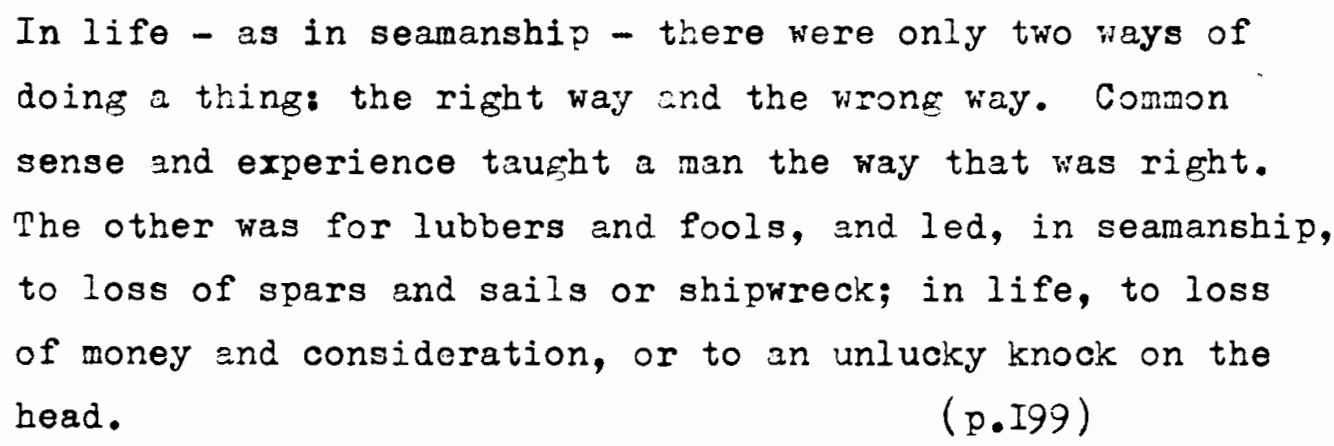


cowed family; Iingard's realm takes in Sambir together with a network of trade that reaches far up-river, and he wields an absolute authority over all. What gives him his power is the fortunate dovetailing of two structures of belief. Though not a religious man, Lingard derives his confident outlook from the Sunday-school teaching of his native village and from his early contact with the Mission to Fishermen and Seamen. From there, too, there stems his impulse to shape stray lives "under his busy hand" (p.I98). To the Malay community who are only too happy to fall under his despotic spell he represents, at the same time, a magical presence, the Rajah Laut, or Kins of the Sea, a title almost equivalent to that of the semi-divine Anals Agong or Son of Heaven whose mystery still tells on wrs Almayer. 35 Conrad makes it clear that his sovereignty is the product of reciprocally projected traditions. While Lingard plays the part of "sky pilot" the local people interpret his ledgers as books of magic lore (pp.I98,299-300)

So dazzled is Lingard by the immensity of his success that he comes to overlook his human frailty. From an instrument of divine purpose he turns into that purpose itself. As is to be expected of the man who has lived "for years beyond the pale of civilized laws" (p.235), he evolves some idiosyncratic notions of justice and never wavers in carrying out his resolves. His fiats are received throughout his territory as "preordained and unchangeable" (p.235), immutable as Allah's law. Though the narrator holds back, the main lines of a critique of Lingard's character are quick to emerge. 
We are allowed to glimpse the little red eyes that, glaring out like "a pair of frightened wild beasts couching in a bush" (p.I88), betray depths of insecurity behind the swaggering front. More crucially we see that the generosity which is bis most remarkable trait often masks a compulsive need for applause, and furthermore that his habit of having his way leads him to place a premium on deference among his acquaintances and friends (op.I5-I6,32).36 Lingard remains, all the same, a likeable character and Conrad suggests that he is redeemed not only by the endearing intensities of his Quixotic personality but by his public role. It seems, in a word, that he plays the part of Providence well:

His deep-seated and immovable conviction that only he - he, Lingard - knew what was good for them was characteristic of him, and, after all, not so very far wrong. He would make them happy whether or no, he said, and he meant it. Ilis trade brought prosperity to the young state, and the fear of his heavy hand secured its internal peace for many years. (p.200, my italics)

The wording of this defence echoes a passage from Alfred wallace's The Malay Archipelago (I869), one of Conrad's favourite books, in which the naturalist concludes an enthusiastic account of "Rajah" Brooke's rule of Sarawak with the reflection:

That his government still continues, after twenty-seven years ... is due, I believe, solely to the many admirable qualities which Sir James Brooke possessed, and especially to his having convinced the native population, by every action of his life, that he muled them, not for his own advantage, but for their good. 37 
Wallace's championship of the adventurer turned tuan reinforces the apology for "paternal despotism" to which he repeatedly returns in the course of his travelogue. ${ }^{38}$ Such a systein comprises, he readily admits, a violation of his own liberal views:
we Englishmen do not like despotism - we hate the name and the thing, and we would rather see people lgnorant, lazy, and vicious, than use any but moral force to make them wise, industrious, and good. 39

He excuses himself, however, from applying his principles on the shaky ground that primitive people constitute a special case. The notion of social progress that he proceeds to adauce obviously owes much to the evolutionary sciences:

\footnotetext{
There are certain stages through which society must pass in its onward march from barbarism to civilization. Now one of these stages has always been some form or other of despotism, such as feudalism or servitude, or a despotic paternal government; and we have every reason to believe that it is not possible for humanity to leap over this transition epoch, and pass at once from pure savagery to Iree civilization. 40
}

Wallace speaks of a "struggle for existence" among the Dyaks (that will lead them in due course to "a more complicated social state") in the same way that he speaks of the "struggle for life" anong animals and plants. 4 I $A$ notable feature of his inferences is that he takes the various peoples of Malaysia as the representatives of fossilized stages in his own culture. What sustains his argument is a crude notion of social evolution as at once fixed, single and hierarchical - unsurprisingly he makes free play with various 
metaphors on "steps". In view of the vastly destabilizing effects of evolutionary theory it is ironic that he should fall back on a world picture that amounts to nothing more than the old scala naturae translated from space into time. Even when he borrows a metaphor from the life sciences, quaintly using the term "missing link" to denote the differences between European and local culture, ${ }^{42}$ he tacitly relies on a version of the famous chain of being. All movement is uniform and upwerd and there are to be no leaps. In the last analysis, it is really through a displaced version of Providence that Hallace reconciles himself to the idea of racial hegemong and honorary paternal care.

Al though Conrad turns a blind eye to Lingard's native subjects he follows up every symptom of dependence displayed by his protégés. Once disaster has struck in the form of the Arab take-over of the river, Almayer reproaches his patron for his unreasoning benevolence, bitterly describing himself as one of "the victims of your infernal charity" (p.I6I) but he ends his outburst, all too characteristically, by lamenting Iingard's absence over the period of crisis. The weak will that several critics have observed in Almayer finds a sanction in the subservient stance he adopts towards his manager. About Lingard his dreams and energies revolve - we learn that he allows his watch to run down whenever the Captain is out of the river and in him he reposes such trust that when Willems warns of his imminent treachery be takes refuge in the simple consolation that since nothing has gone seriously wrong in the past, nothing ever will (pp.308,93). That he should spend the fatal night of Lakamba's 
assault sewn into a hemmock and humped about like a bale of goods underlines the atrophying effect of his habitually passive part in Lingard and Co. The image has its own finality; but the analysis of tutelage is carried further not only through the portrayal of desolation that overwhelms Willems after his betrayal of his benefactor, a loss of self that prompts yet another abject bid for rescue, but through the empty revolt of Willems's and Almayer's wives who, in suffering the loveless marriages engineered for them by their respective patrons, Hudig and lingard, taste the bitter fruit of casual benevolence. When willems belatedly discovers that Hudif has married him off to his illegitimate daughter he makes a telling comment: "while he worked for the master, the master had cheated him; had stolen his very self from him" (p.36).

One of the consequences of Iingard's paternal despotism is that his satellites grow reluctant to accept responsibility for what happens to them. Iike those equally improvident "waiters upon Providence", the Durbeyfields of Tess, Willems and Almayer favour a fatalistic reading of their histories. 43 "It wasn't me. The evil was not in me", Willems urges - with all sincerity - when Lingard agrees to see him after his disgrace ( $p .273)$. He convinces himself (and some readers too) that he was forced into disloyalty by Babalatchi's schemes; but his pretence is given the lie by the single consideration that he has all along sought to betray Iingard's secret, even at the moment that Lingard has for a second time come to his aid (pp.I8,43). 
the richest and most innovative writing of the novel. Because Willems is eager to disown all aspects of himself that have led to trouble, he camouflages many of his impulses as external forces acting upon him. His passion for Aissa accordingly becomes the "thing that came over me", a "madness", even possession by the devil. So it is that re witness through his eyes the metamorphosis of his compliant lover into a predator, jailer, murderer and thief (pp.269-73). Willems distorts reality, however, at the cost of creating a split within himself. In some superbly realized sequences he is shown grappling with his double - in the form, first, of a "slippery prisoner" over whom he has charge, later in that of a distant figure receding ever further into undergrowth (pp.78, I45). The idea that sustains the presentation of Willems's breakdown closely parallels the psychoanalytic sense of projection started by Freud with a paper on anxiety neurosis ( I 894 ) in which he argues that when the psyche is led into dangerous conflict by a deep, somatic desire it reacts as if it were threatened by an external object 44 - a mechanism he was to illustrate later in the case history of the paranoid Dr Schreber. 45 Appropriately, it is when willems most vehemently asserts his purity that Aissa appears most evil; or egain, when he most fiercely declaims his innocence that the jungle assumes its darkest aspect ( $p .27 I$ ). To be aware of projection is to take responsibility for oneself.

Willems remains an arrested being: he repudiates the wilderness into which he moves, and his awakened sense of reality is smothered before it quickens into growth. Conrad provides through his uncongenial hero - who alternates between god and underdog, puppet and puppeteer a twofold exposition of the stunting effects of patronage. Bloated 
will as much as starved initiative contribute to Willems's incessant defence against the new. Self-imprisonment and projection prove to be his habitual ways of fending off the challenges to an immature soul. Whether he revels in his flattered ego, or fails out of timidity to possess the resources of a freshly disclosed self, the outcome is the same. Conrad's choice of an anti-hero who acknowledges little while being exposed to much enables him to dramatize the gulf between a typically sheltered view of life and the novel's austere insight, an insight which derives, in part, from nineteenth-century science. In An Outcast Conrad set out to undermine what Freud was to call "presumption on the part of man"; and one of his targets, a myth whose detection Freud ascribed to Darwin and his collaborators, was the notion of "a divine descent which permitted [man] to break the bond of community between him and the animal kingdom". 46

Conrad's depiction of his hero's passion for Aissa has been read as an outright condemnation of sexual love. 47 But it is, rather, Conrad's appreciation of erotic intensity that gives him insight into the way love can represent a dire threat to the ego. His eract identification of sexual desire with the experience of death (pp.80-I, I4I,I52) is in keeping with a recent insistence on the continuity of violence and lust: so Georges Bataille, for instance, opens his Death and Sensuglity with the question, "What does physical eroticism signify if not a violation of the very being of its practitioners?" 48 The truculence of Willems's passion is a part, in any case, of the overall stress that Conrad lays on the moral ambivalence of our deep-seated energy, a theme which flows from a perceived disjunction 
between social identity and the instinctual life. Hillems's sensations, variously described as "deadly happiness" (p.I4I), "idiotic beatitude" (p.I40), and "delirious peace" (p.I4I) express the paradox of a human psyche, the parts of which do not cohere in accordance with some master plan.

Accounting in The Malay Archipelago (IE69) for a staple of Dyak diet, Wallace remarks that the huge juicy fruits of the Durian are not infrequently also a cause of death:

Poets and moralists, judging from our English trees and fruits, have thought that small fruits always grew on lofty trees, so that their fall should be harmless to man, while the large ones trailed on the ground. Two of the largest and heaviest fruits known, however, the Brazil-nut fruit (Bertholletia) and Durian, grow on lofty forest trees, from which they fall as soon as they are ripe, and often wound or kill the native inhabitants.

After describing the damage inflicted by the spiny cases of the fruit he impresses a sober moral on his readers:

From this we may learn two things: first, not to draw general conclusions from a very partial view of nature; and secondly, that trees and fruits, no less than the varied productions of the animal kingdom, do not appear to be organized with exclusive reference to the use and convenience of man. 49

Both plots and setiing of An Outcast of the Islands radiate from a vision of man's eccentric place in the universe, and the lesson drawn by the great naturalist, whom Conrad hailed not only as a pioneer explorer but as a "profoundly inspired" man, provides a suitable epigraph to the early work. 50 
The Hidden Man:

Heart of Darkness, its context and aftermath

Placed between Youth and The End of the Tether in a volume which Conrad once described as a rendering of the "three ages of man", Heart of Darkness resolves, from a little way off, into a composite image of lost innocence. I A central evil looms against a range of human hopes and draws depth from the relief. There is the dimming of Kurtz's original idealism, guyed at the central station and reflected at the end in the pale purity of the Intended. There is the clouded naiveté of the "Harlequin" whose round eyes have grown used to horror; and there are, though of differing sincerity, the pious pretences of the Aunt and of the company which the narrative bluntly punctures. For Narlow the trip up the Congo marks no less than life's "culminating point" (p.5I), and what brings his crisis to a head is the recognition of a truth which passes relatively undisguised in the remote setting and emerges plainly in Kurtz. The grim disclosures that await Marlow at the continent's centre acquire a universal status, and the journey into the interior takes on, in consequence, the character of a psychologicel progress. That the journey carries the further implication of a return to a primordial past shows that Conrad is intent, once again, on impressing the view, current among, many writers in the thrall of evolutionary theory, that man is irrecoverably shaped by his origins, flawed by a darkness welling from his heart.

But while Marlow's story revolves about the brutality of the instinctual life, we are made aware, from the first, of man's capacity to distance himself from his impulses. Action aboard the sea-bound 
Nellie is suspended as the incoming tide swings the yawl about her anchor in the Thames and her resigned pilot retires sternwards to foin a listless crew. Then it is that, through the eyes of the bridging narrator, we glimpse Marlow sitting with legs crossed "right aft":

He had sunken cheeks, a yellow complexion, a straight back, an ascetio aspect, and, with his arms dropped, the palms of hands outwards, resembled an idol.

Over the immensity of the twillt scene Marlow broods like a Buddha (the comparison is offered three times - pp.50,52, I62), and his mood spreads through the group of friends as the narrator dryly observes:

We exchanged a few words lazily. Afterwards there was silence on board the yacht. For some reason or other we did not begin that zame of dominoes. We felt meditative, and fit for nothing but placid staring.

The switch between active and meditative states reappears in Kurtz (who is as much icon as beast once pacified by the current of the African river); and for many readers this interplay would have had behind it the famous distinction drawn by Schopenhauer between the world as will and as idea. Conrad seems to have held, like the philosopher whose work he knew well, that while reality is grounded in the instinctual life, any true representation of it entails a relaxation of the will. ${ }^{2}$ Oriental belief is frequently invoked in The World as Will and Idea to illustrate the notion of "pure perception" but Schopenhauer's thinker lifts the 
veil of illusion to find, not the omnipresent Godhead sought by the Buddhist or Brahmin, but a cycle of energy and pain from which he is only momentarily free. On this view the release that consciousness brings is necessarily fraught with tragic insight: and it is such a notion that Conrad voices in a letter to Cunninghame Graham:

What makes mankind tragic is not that they are victims of nature, it is that they are conscious of $i t$. To be part of the animal kingdom under the condition of this earth is very well - but as soon as you know of your slavery the pain, the anger, the strife - the tragedy begins. ${ }^{3}$

This comment has a particular bearing on Heart of Darkness ( I899) for it was the Congo, Conrad told Garnett, that put an end to that golden period of his youth when, without a "thought in his head", he led the life of "a perfect animal". 4

The picture of innocence that unfolds in Youth is Narlow's picture of himself on his first long voyage. Here, in place of the dégagé, almost sardonic narrator of Heart of Darkness, we have a rhapsodic Marlow bent on recapturing the lost sources of his joy - "Oh Youth! ... pass the bottle", is the chant of his rite. Self-absorption is the premise of the story through which the youth moves in a cocoon of self-generated assurance, neither minding disaster ("Now this is something like. This is great. I wonder what will happen", he exclains when the deck blows up about his feet), nor responding to the shadowy world that lies beyond the blaze projected by his high spirits: 
Oh, the fire of [youth], more dazzling than the flames of the burning ship, throwing a magic light on the wide earth, leaping audaciously to the sky, presently to be quenched by time, more cruel, more pitiless, more bitter than the sea and like the flames of the burning ship surrounded by an impenetrable night. 5

Though Conrad's appreciation of these energies is more generous, his youthful hero resembles, in his state of blithe encapsulation, Schopenhauer's type of the unregenerate whose vision is blinkered by a principium individuationis. Happiness, in this sphere, is "only the dream of a beggar in which he is a king, but from which he must awake [to] the suffering of his life"; and perception is limited to "phenomena as separated, disunited" rather than being levelled at "the inner nature of things, which is one"."

The parallel is telling for it underlines an important feature of Heart of Darkness - a tendency to abstract, to assert underlying rhythms and set echoes going. Though this principle may begin with atmosphere, with that "sinister resonance" which Conrad was at pains to play across the whole, it reaches, as we shall see, into the metaphoric and thematic structure of the work, and constitutes itself finally as that search for kinship which is, in essence, Marlow's quest. ${ }^{7}$ One pointer to Conrad's esemplastic concern comes in the striking comparison of Marlow's story-telling to a haze illuminated by an inner source of light. Such a unifyine radiance contrasts with the discrete, final sense of the downright sailor's yarn ("the whole meaning of which lies within the shell of a cracked nut", p.48), and the contrast is given further force by the immediately 
foregoing account of how Marlow's wanderlust sets him apart from the run of sailors for whom "home is always with them - the ship" (p.48). The image lingers, for Marlow reports shortly that his crisis in Africa "seemed somehow to throw a kind of light on everything ... and into my thoughts. It was sombre enough ... and yet it seemed to throw a kind of light" (p.5I). This numinous glow stands at a remove frou the brilliant imagery of flame accorded, in the earlier story, to a younger, still ardent self.

That the hero of Youth rejoices in the life of will and remains rooted in the phenomenal world, does nothing to restrict his love of adventure, however. The Far East holds for hin, unlike others on his boat, all the whispered promise of mysterious delight"; and on arriving there he imagines himself gazing at terra incognita through the ejes of "ancient navigators". It is, indeed, this romantic, wilful exploration that sets off Marlow's disenchanted view in Heart of Darkness. For here the first narrator, when he celebrates the "great knights-errant of the sea", draws on just the sort of descriptive colour used in Youth, his roll of great Englishmen conjuring up something like a firework display over the Thames. In reply to his chauvinism Marlow piotures the Roman exploration of Britain, incidentally telescoping the proud imperial metaphors of "torch" and "sacred fire" into a mere "flicker" in the passage of time $(\mathrm{pp} \cdot 47,49)$. But even before he receives his answer some irons creeps into the narrator's collocation of glorious deeds ranging

from the Golden Hind returning with her round flanks full of treasure, to be visited by the Queen's Highness and thus pass out of the gigantic tale, to the Erebus and Terror, bound on other conquests - and that never returned. 
Conrad accentuates the note of mortality struck in the reference to Franklin's Arctic trip by pointing up the lexical clash of the ships' names (in Youth the night sky is "black, black as Erebus"), but he could count also on his reader's familiarity with the gruesome outcome of this expedition - the starvation, and the cannibalism practised by some last survivors. ${ }^{9}$ For a moment the lamp of adventure gutters in the dark, oppressive air of Falk (I903) whose forbidding hero staves off death in icy latitudes by eating a man he has killed in self-defence.

Marlow's sketch of the Roman settlement in Britain serves as a strategic link between the romantic parade of English explorers and the Belgian occupation of the Congo which provides the ohief subject of the novella's first part. It opens up a field for Janus-faced comparisons in which Britain figures both as wilderness and as invading power. Despite the occasional vague word that Marlow puts in for imperialism (on rereading we may be reminded of Mark Antony's "And Brutus is an honourable man"), the main thrust of his preamble is directed against colonization which he strips down to realpolitik:

It was just robbery with violence, aggravated murder on a great scale, and men going at it blind - as is very proper for those who tackle a darkness. The conquest of the earth, which mostly means the taking it away from those who have a different complexion or slightly flatter noses than ourselves, is not a pretty thing when you look into it too much.

$(\mathrm{pp} .50-\mathrm{I})$

Although Marlow is speaking here of the Romans it is with a generality that comprehends not only the Eldorado Exploring Expedition who set off into the tropical forest with all the rapacity of "burglars 
breaking into a safe" but even the Golden Hind returning from the New World with treasure-laden flanks $(\mathrm{pp} .87,47)$. The other face of the Janug-headed equation, that of Britain as subject nation, crops up again when Marlow, well-launched into his account of the Congo Free State, comments on the depopulation caused by the colonizers, what would happen, he asks, if a body of mysterious, armed men "took to travelling on the road between Deal and Gravesend, catching the yokels right and left to carry heavy loads for them" (p.70)? The comparative view - "truth stripped of its cloak of time" (p.97) - is the habit of Marlow's outlook, and it is around the issue of exploration that his recurring concern with lost innocence first crystallizes.

What tempts Marlow into seeking immediate employment with the company is the snake-like course of the Congo, glimpsed on a map in a shop window, but his itch for African adventure goes back to the fascination he felt as a boy for the largest blank on his atlas. The magic of this space is, however, a thing of the past; and that "mysterious delight" which the Marlow of Youth associates with unvisited places has al together vanished with it: ${ }^{\text {IO }}$

It was not a blank space any more ... It had ceased to be a blank space of delightful mystery - a white patch for a boy to dream gloriously over. It had become a place of darkness. (p.52)

In context the image has particular force for while it sustains the tonal contrasts of the opening, and restates Marlow's rebuttal of the first narrator's rhapsody, it introduces a rhetoric of oancellation, instances of which will range from the comic, 
... the great man himself. He was five feet six ... (p.56)

... he was amezing, and had a penholder behind his ear ... (p.67)

to the sinister,

[he] was making correct entries of perfectly correct transactions; and fifty feet below the doorstep I could see the still tree-tops of the grove of death.

$(\mathrm{p} .70)$

Marlow's blank map provides a foil as precise as that supplied by the dazzlingly punctilious Accountant and one more comprehenaive for it functions as a symbol of innocence, an innocence full-blooded enough, moreover, to include the assertive aspects of selfhood. To the usual associations of whiteness the empty space adds the spice of invitation. To the dreamer it offers a screen free of interference, and to the adventurer a challenge. Even an explorer as beset by unforeseen hazards as was Stanley on his first crossing of the continent, could find a tonic in the prospect of entering uncharted territory. "This enormous void", he declaims, "blank as it is, has a singular fascination for me":

"Never has white paper possessed such a charm for me as this has, and I have already mentally peopled it, filled it with most wonderful pictures of towns, villages, rivers, countries, and tribes - all in the imagination - and I am burning to see whether I am correct or not ... To-morrow, my lad, is the day we shall cry - 'Viotory or death!'"II

Between blind elation of this kind and the contemplative brooding of Marlow there falls the social and psychological experience that finds expression in Heart of Darkness. 
And in describing the biographical roots of this experience Conrad turns once again to the contrast between his childhood fantasy of the blank map and its sordid realization, almost two decades later, at Stanley Falls:

Yes, this was the very spot. But there was no shadowy friend to stand by my side in the night of the enormous wilderness, no great haunting memory, but only the unholy recollection of a prosaio nerspaper "stunt" and the distasteful knowledge of the vilest scramble for loot that ever disfigured the history of human consoience and geographical exploration. What an end to the idealized realities of a boy's daydreams! I wondered what I was doing there. I2

It is clear from the essay "Geography and Some Explorers", from which this passage comes, that the Congo Free State played a part in Conrad's development comparable in some respects with the French Revolution or the events of 1848 in the lives of previous generations of writers. Spelling out the reality of Leopold's colony, a speaker in a parliamentary debate of 1903 applied, really rather tamely, a remark of Guizot's on the Second Republic: "it began with Plato and ended with the gendarme". I 3

When Conrad joined the Société Anonyme Belge it was on the understanding that he rould be part of an inland exploring party under the leadership of a certain M. Delcommune. I4 The essay on geography shows how his appetite for such adventure had been stirred by an extensive and lifelong reading of African explorers. I5 To this literature Heart of Darkness, al though it ranks among Conrad's most closely autobiographical works, reveals an important debt, and one that has 
escaped due attention. The natter is delicate not only because the exact limits of Conrad's experience will never be clear (the Congo Diaxy gives away little) but because the influence proves remarkably far-reaching and tenacious. There are, within short range, a variety of descriptive parallels, a brief list of whioh would certainly include the shattering account of conditions on a coastal mine placed near the start of Schweinfurth's The Heart of Africa (I873), ${ }^{16}$ Stanley's lecture to the irritable Barttelot on the necessity for restraint in the tropics, and, from In Darkest Africa (I890) again, his recurrent application of sea and beast imagery to the jungle. ${ }^{I 7}$ There are, too, as we shall see, some strong points of resemblance between the personalities of Kurtz and Burton. Further sought but more deeply pertinent, however, are the formal characteristics that Heart of Darkness shares with African travelogues of its period.

In his essay on exploration Conrad remarks on the way the scientific spirit of "militant geography" had larcely given place in his lifetime to less disinterested forms of travel; and this change is refleoted in a switoh towards more popular narrative modes in most travel writing. Even writers like Barth and Schweinfurth who uphold the tradition of Humboldt make substantial concessions to an audience on the lookout for adventure. And while Schweinfurth often shows himself torn between his avowed aim of demythologizing Africa and an urge to instil suspense, his work, after the lapse of a decade, is singled out as an example of all thet is reductive in the scientific mind by Stanley, who boasts of his own success in "relegating dryness to the maps". I8 Another contribution to the collapse of empirioal austerity in Africa is proposed by Philip Curtin who points out that 
as routes became more taxing, explorers were "selected for their ability to make a difficult journey and still survive". I9

One upshot of this development was the importation of dynamic plot to the travelogue, and in the case of such popular successes as Burton's Mission to Gelele (I864), Schweinfurth's The Heart of Africa (I873), and Stanley's How I Found Livingstone (I872) or his In Darkest Africe (I890) it is essentially the same plot: a journey into the interior leads, at its furthest point, to a climactic meeting, usually with an important personage (the King of Dahomey, Iivingstone, Emin Pasha, - in Schweinfurth's case, with the Pygmies) about whom the reader is kept briefed from the first. The climax, furthermore, often brings some horrifying disclosure - cannibalism among tre neighbouring tribe to the Pygmies, the Niam-Niam, in Schweinfurth; human sacrifice at Gelele's annual So-Sin custom in Burton; or, failing that, a resource of which Stanley makes the most, a subtle reversal of expectation such as the laconic greeting of Livingstone, or the guarded reception by Emin Pasha of his would-be rescuers. Plots of this kind are, of course, not confined to travelogues; and the poignant yet anti-climactic encounter between Marlow and Kurtz could be paralleled almost as well by the hunt: conducted in Henry James's The Aspern Papers (I888) by the narrator in search of a mentor's relics, were it not that the African setting raises an important assumption of the period that gives further life to a formal comparison. Almost without exception, the explorers concerned are tempted to regard Africa as a segment of primeval history miraculously translated to the present. 20 
(and there is a tendency to see the centre of the continent as their proper home) still cling to "great mother Nature"; from which it is a short step to describing Africa as "the embryo of the most advanced civilization". And, for all his debunking, Schweinfurth parades the Pygmies, when they at last appear, as if they were mysterious castaways on the evolving globe - "a living embodiment of the myths of some thousand years!" $2 I$ Even men as diverse in outlook as Livingstone and Burton find common ground in the nostrum of a living past. For Burton, East Africa lays bare "man's rudimental mind" while for Livingstone the traveller is "thrown back in imagination to the infancy of the world". 22 stanley adheres, most persistently of all, to the imagery of creation. He compares a Fygmy couple met on his route to Adam and Eve, adiing for good measure that they represent "the oldest types of primeval man". Though his idea of genesis is evolutionary, the Old Testament frequently runs in his head: mist rising over Lake Albert recalls the description of Chaos, and, echoing Genesis again, he prides himself on being the first European to gaze on the Congo basin "since the waters disappeared... and the earth became dry land". To the mysterious immanence of the past stanley frequently returns, comparing all life on the continent to an unageing Rip van Winkle, and Africa itself to the dark stillness of the hours before dawn. 23

Coming back to Heart of Darkness, we find not only that Narlow's journey into the interior is shadowed by a figurative recovery of the past but that his whole approach to Kurtz is charged by the metaphor. At a first view from the sea, the landmass of Africa has a nascent look, "almost featureless, as if still in the making" (p.60), 
and once the central station is put behind, the comparison resurfaces:

Going up that river was like travelling back to the earliest beginnings of the world, when vegetation rioted on the earth and the big trees were kings.

From then on the primeval aspects of the settings are focussed often enough for phrases such as "the night of the first ages" to take on an incantatory quality. Out of the metaphor of time-travel Conrad develops a trajectory far more conspicuous than that found in any travelogue, but his aims are principally psychological, and he avoids the literalism that marks the "living fossil" theme in much fiction of his period. 24

Many novelists proved only too keen, indeed, to trade on a pseudo-scientific resurrection of the monsters that "militant geography" had laid long back. In J.P. Webster's The Oracle of Baal (1896), for example, a Professor and his companion stumble on the Affri (a band of anthropoids) before reaching a "cave of sleep" at the continent's centre, which holds the bones of many extinct creatures and a monstrous ape. Though in more muted guise, the idea of a mysteriously preserved past enters King Solomon's Mines (IE86) when the explorers find themselves trapped in the presence of the Kukuana dead, silicified over the centuries by the dripping roof of their cavern. A more sprightly version of Haggard's "hall of death" turns up in Buchan's Prester John (I9IO) where the rites and regalia of a newly revived cult, dating back to the queen of Sheba, are housed in a resplendent grotto. Whether Conrad was acquainted with this tradition of "African" novels it is hard to say, but his debt to the travelogues certainly seems to have been reinforced by a knowledge of A Journey to the Center of the Earth 
(I864), the famous fantasy by Jules Verne in which a professor and his nephew encounter, on their way down a volcano, living specimens from ever more ancient history - an enraged ichthyosaurus figuring prominently among the beasts they watch. Marlow on viewing the coastline only feels that he is "about to set off for the centre of the earth"; and the "ichthyosaurus" covered with glitter is his imaginative reading of a bathing hippo $(p p \cdot 60,86)$. To his surroundings he responds, it is fair to say, as would any cultivated Victorian.

What, in fact, distinguishes Marlow as a traveller is the readiness with which he acknowledges kinship with the African setting. He makes his journey, as we shall see, the occasion of a series of insights into the atavistic sources of his own mind. One aspect of this recovery is the affinity he discovers between himself and Kurtz, who has in the course of his regression effectively reversed, as Ian Watt puts it, "the direction of historical evolution". 25 It is clearly Conrad's intention that Marlow should be seen to find, in his long-delayed meeting with the tantalizing stranger, a fully explicit version of his own buried identity. There is an irony in that what lies in wait for Marlow at the end of his quest proves to be an image of himself. But although such structural feats belong to fiction rather than to the travelogue, similar subtlety is at work in Burton, that most shrewd and brisk of African explorers, who not only highlights the changes he experiences in himself on escaping the bonds of civility, but delights in showing that the excesses of the dark continent are in no way foreign to Europe though they may exist there in camouflaged form. In the opening pages of his First Footsteps in East Africa (I856), the account of his journey to the Moslem stronghold of Harar where he 
passed as an Arab - as he had done earlier in Mecca - Burton gives a diverting account of the way his party, on entering the desert, broke into all the "joviality arising from a return to Nature". 26 He quotes a line from Dryden's Conquest of Granada celebrating man in his "free" state, and noting the easy happiness of his Arab companions, wryly remarks that "it is not only the polished European [who] lapses with facility into pristine barbarism". 27 He takes up the same topic in a more sonorous way at the start of Zanzibar (1872), insisting on the physical exuberance that rewards the man who shakes off "the fetters of Habit... and the slavery of Home". 28 Marlow, though less of a primitivist and correspondingly less susceptible to the allure of the outward-bound, does at least admit a thrilled response to his surroundings $(\mathrm{p} .96)$. That he keeps his desire in check, refrains, in his own words, from going ashore "for a howl and a dance" (p.97) marks the boundary between himself and Kurtz, whose lack of inhibition in this regard may well owe something to Burton. Kurtz is repeatedly associated with "midnight dances ending with unspeakable rites" (human sacrifices are hinted at), and it is on such an occasion that Marlow nobbles him as he crawls on all fours before a swaying figure with a headgear of horns (po.II8,I42-3). The scene represents the nadir of atavistic regression for Kurtz, and also for Marlow who revels in the "boyish game" of tracking down his quarry and, on finding him, threatens to smash in his head. Marlow revealingly owns that the beating of the drum became confused, at this point, with the beating of his heart (p.I42); and it is worth noting here that tribal dancing seems to have supplied a particularly good touchstone in the nineteenth century of attitudes towards the primitive. At one extreme there is Robert Moffat, the missionary, for whom the sight of dancing blacks raised the spectre 
of hell-fire: "There has been much dancing and singing today", he records on visiting the Matabele, "it is a terrible barrier, not to know the language of a people who are dancing on to everlasting destruction." 29 For reasons less doctrinaire Schweinfurth also found the sound repelling, so much so that he sprinkled the parchment of some Nubian drums with muriatic acid. 30 Burton, however, seems never to have missed an opportunity for joining in the revelry. In a climactic scene from his Mission to Gelele he tells how he took part in the dance that initiated the complex rituals of human sacrifice at the Dahomey court, both imitating the king's decapitating gestures, and drinking to his health from a cup made of an enemy's skull. 3I His account includes the short sketch of a sorceror who sways about and presides over the dance with horns attached to his head. ${ }^{32}$ But despite the sensational nature of the matter he conveys, Burton is careful to sabotage any pat recourse to moral shock on the part of his readers. If Byron drank from a skull, why not Gelele? Or, come to that, are the captives and criminals executed in the state rituals of Dahomey treated with less dignity than the victims of public hanging in Europe? And is the Dahomean custom of gluing a cowrie shell with blood onto the musket stock for each dead foe really any different from the English practice of decorating soldiers, seeing that it too "stimulates murder, and excites perpetual jealousies in the service"? 33 Because of these dry, Nontesquieu-like sallies into comparative savagery, as well as his sensual abandon, Burton supplies a bridge between the dark continent and a European audience, and Kurtz functions in the same way.

One indication of Kurtz's representativeness is that proposals for models of him have never been in short supply. Many historical figures 
contributed to Conrad's portrait and Burton, even if his claims have been overlooked, is surely among them. Although he seems to have lacked Kurtz's degree of cruelty and to have left, unlike Stanley, a record quite free of slaughter, Burton had a reputation for what Livingstone broadly terms "bestial immorality" and was more often known as "the white nigger" than by the tag of "amateur barbarian" that he gave himself. 34 with Kurtz he shares not only a remarkable range of intellectual gifts but a link also with diabolism that he did much to flaunt. 35 Just as Kurtz is alternately seen as angel and fiend, so Burton was credited by Swinburne with "the brow of a god and the jaw of a devil", while to the more prosaic Speke he became the man who had "gone to the Devil in Africa". 36 His interest in erotica and his lifelong campaign against Victorian prudery (of which his Arabian Nights translation was only a part) lie behind his boast that he "speaks the things that others think and hide". 37 It was probably the candour with which he expressed his nihilism and lust that turned him, after his death in I890, into a hero of the fin de siècle. Tributes to his physical vitality and profound despair go hand in hand. In language close to some of Marlow's, Jwinburne speaks of "the look of unspeakable horror in those eyes which gave him at times an almost unearthly appearance". 38 And while Arthur Symons testifies to his "tremendous animalism, an air of repressed ferocity, a devilish fascination", Frank Harris assures that "deep down in him lay the despairing gloom of utter disbelief". 39

Conrad's debt to the explorers turns out, then, to be a complex one. Biographical influence apart, it ranges from specific if unconscious borrowing to a deep abstraction of form. But the travelogues bear on 
Heart of Darkness in still another way. Conrad was addressing an audience whose ideas of Africa and particularly of the Congo were largely moulded by their reading of travel writing, much of which sold very well. During the eighteen-nineties the eyes of Europe were fixed on Central Africa in any case, and Conrad's readers were in some respects fairly well informed. Wy contention, then, is that Conrad uses certain images with an awareness of the significance they held for a wide public and that, because this significance has in some cases been lost, the full argument behind his exposure of conditions in the Congo no longer shows. Where these conventions come most strongly into play is in the picture of the social evil that accounts for Marlow's lasting disillusion.

While it is true that explorers paved the way for the colonization of Africa they were often critical of it and responsible to some extent, too, for the campaign against exploitation that began to gather impetus before the publication of Heart of Darkness. 40 Even Stanley, twice in the employ of King Leopold, found it expedient to warn against unscrupulous rule as early as $1890.4 I$ But the voice of protest was raised first in connection with slavery, long before imperialism took hold in the continent during the eighteen-eighties. And there can be no doubt that the efforts, principally of Livingstone, but also of Cameron, Baker and many others greatly advanced the move to end slavery in Africa, hastening in particular the decisive treaty with the Sultan of Zanzibar of 1876 , which broke the main channels of the Arab trade. So deeply was the public imagination stirred by the abolitionist cause that the European powers were quick to appropriate it as a chief weapon in the moral armament of empire. By far the most notorious case is that 
presented by the Belgian king who in a spirit of cold cynicism put abroad a smokescreen of pious pretence behind which he manoeuvred himself into private ownership of the Congo. 42 Many were the scientific and philanthropic institutions, including a Society for the Suppression of Slavery (known to Kurtz) through which he rallied support for a goal which he saw entirely in terms of national status and his own gain. He seems to have sensed that the anti-slavery lobby would provide the most effective spearhead in what he advertised as a latter-day Crusade. He certainly knew what he was about when, in his inaugural speech at the first of many international conferences, he re-echoed the words recently engraved in ilestminster Abbey on Livingstone's tomb. "May Heaven's rich blessing", the explorer's legend read, "help to heal this open sore of the world"; and Leopold's speech ran:

Before the horrible evil of the slave-trade, which in the interior of Africa claims over I00,000 victims yearly, the citizens of civilized countries must come to an agreement to heal the sore. The headquarters of this humane undertaking might well be situated on Belgian soil. 43

The first trading stations on the Congo were set up accordingly as "'pacifying' bases from which to abolish the slave trade", and they were modelled, in theory, on the socialist ideal of the phalanstères. 44 Another counter in all the talk (among a circle known to Marlow's Aunt) was the redeemed slave, to be known as the libéré. 45

Marlow's description of his first view of the workers at the company station is justly famous. Without any striving for pathos it unfolds a series of images which are devastating in their precise notation of misery and degradation: 
A slight clinking behind me made me turn my head. Six black men advanced in a file, toiling up the path. They walked erect and slow, balancing small baskets full of earth on their heads, and the clink kept time with their footsteps. Black rags were wound round their loins, and the short ends behind waggled to and fro like tails. I could see every rib, the joints of their limbs were like knots in a rope; each had an iron collar on his neck, and all were connected together with a chain whose bights swung between them, rhytrmically clinking.

For contemporary readers, however, this passage carried, along with its kinetic evocation of feeling, a quite distinct iconographic significance. The chain-gang with an armed escort (who appears here, at the end of the paragraph) was the most basic of the images associated with slavery in Africa. Such a procession was described by every explorer from Mungo Park to Stanley and frequently illustrated in accompanying plates. 46 The fact that the men Marlow sees are required to work while in chains, again falls in with the picture of Arab cruelty painted by traveller after traveller - Park, for example, dwelling on the pain caused to slaves in the file by "walking quick with heavy loads upon their heads". 47 One of the most wrenching passages in Livingstone's work describes the "broken-heart" that overtakes, and often kills, those who pass life "chained together by the neck, and in the custody of an Arab armed with a gun"; 48 and this aspect of slavery, too, is reflected in Narlow's mention of the "deathlike indifference" of the men in the chain. Norman Sherry has suggested that it is very unlikely that Marlow's observations at the company station were drawn from Conrad's own experience at Matadi (there is, for one thing, no word in the Congo Diary) and this leaves us freer to speculate on the strategy that underlies a shattering scene. 49 
And really the point is clear. Conrad is out to show that slavery persists in everything but name, and that, for all the banners of Holy War, the Congolese have done no better than suffer a change of masters. The passage looks forward to a central tenet among Leopold's critics after the formation of the Congo Reform Society in 1904 - and a commonplace of later colonial debate - to what Dilke would term "the general recrudescence of slave conditions in disguise". 50 Perhaps the charge was most bluntly framed by Roger Casement when he refuted the claim that the Congo administration had abolished slavery with the retort:

It has not suppressed the Slave Trade, it has merely substituted itself for the Arab who formerly exacted service from the native. 5 I The political pressures that sustained the supoly of forced labour in the Congo were to be analysed by Morel in a series of books, one of which bears the title The New African Slavery (I904). Crief among these pressures were the appropriation of raw materials by the state; the imposition of taxes; and drastic restricions on free trade. Though these measures were only partially in operation at the time of Conrad's visit to the Congo in 1890 (the situation there was to deteriorate rapidly in the early years of the decade), their implications are brought home, all the same, in Heart of Darkness (I899). The Manager's plan to remove the freelancing "Harlequin" would later have received the sanction of law, but that he can do without:

"Ve will not be free from unfair competition till one of these fellows is hanged for an example," he said. "Certainly," grunted the other; "get him hanged! Why not? Anything - anything can be done in this country." 
No doubt the laws which Leopold introduced in the early nineties often articulated existing practices. ${ }^{52}$ Kurtz's raids for ivory represent only a small deviation from the later, official uses of tax-collectors - which gives a dark twist to the question Marlow asks of the Manager: "Do you', said I ... 'call it "unsound method"?'" (pp. I28,I37, my italics). 53 The official raids were punitive: hands were sometimes brought back as a guarantee that the job had been properly done. And Conrad shows just how loose the concept of punishment at the stations was when the scapegoat for a burning shed is brutally flogged, a company man interjecting: "Transgression - punishment - bang! Pitiless, pitiless. That's the only way" (pp.76-7,80). The true status of the chain-gang of "criminals" described by Marlow would have been specially clear to a number of Conrad's readers. Under the title "Cruelty in the Congo Free State", the Century Magazine had published the journals of Edward Glave, a young explorer who died at Matadi in I895, and he tells how large groups of captives from the punitive raids were shipped, and then inpressed as labour further down the river:

In the fighting consequent upon this policy, owing to the inability or disinclination of natives to bring in rubber, slaves are taken men, women, and children, called in state documents libérés! These slaves, or prisoners, are most of them sent down-stream, first to Leopoldville. 54

To this damning testimony Glave adds the bitter comment:

If the Arabs had been the masters, it would be styled iniquitous trafficking in human flesh and blood; but being under the administration of the Congo Free State, it is merely a part of their philanthropic system of liberating the natives. 55

It is not surprising that Kurtz blindfolds the figure of Liberty in the 
painting that marks his disillusion, or that he presents her countenance as thrown into sinister relief by the light of her own torch (p.79). The eyeless face recalls Marlow's verdict on the Roman conquest of Britain: "It was just robbery with violence, asgravated murder on a great scale, and men going at it blind" (p.50).

Conrad proceeds, in the course of a sentence, to turn the "criminals" in the chain-gang into ordinary company workers, who despite the "legality" of their contracts, are dying of despair in the grove of death: "They were not enemies, they were not criminals, they were nothing earthly now", Marlow reports of the group of huddled figures emerging from the shade $(p .66)$. Throughout the episode attention is focussed on the arbitrariness of the labels that are fixed to a reality which lies beyond immediate apprehension until hideously defaced. A recurring piece of symbolic action captures the sense of an imposition that is at once violent and futile. Marlow is made intermittently avare, as he makes his tour of the station, of blasting in progress on a cliff:

A heavy and dull detonation shook the ground, a puff of smoke came out of the cliff, and that was all. No change appeared on the face of the rock ... The cliff was not in the vay or anything; but this objectless blasting was all the work going on. (p.64)

The muffled explosions that leave the rockface unpuckered recall, from the previous page, the French frigate firing at "enemies" or, in plainer words, shelling the continent. While gazing at the "criminals" Marlow gathers these diverse strands to a single head:

Another report from the cliff made me think suddenly of that ship of war I had seen firing into a continent. It was the same kind of ominous voice; but these men could by no stretch of imagination 
be called enemies. They were called criminals, and the outraged law, like the bursting shells, had come to them, an insoluble mystery from the sea.

The passage is a crucial one for it opens up a vista of cultural relativity against which the European presence stands out as an intrusion. Conrad boldly poses the question, so often shelved in colonial fiction, of what excuse there can be for such a "fantastic invasion". The phrase is repeated three times, and in a context on each occasion that reverberates the earlier "objectless" blasting: the shadows of the Manager and his uncle, to quote one instance, trail "behind them slowly over the tall grass without bending a single blade" (pp.92,76,I3I). Marlow returns to the imagery of the cliff when he accounts for his feelings before that further manifestation of impenetrable innocence, the Intended, whose "soul as translucently pure as a cliff of crystal" fends off the sepulchral voice that still runs in his head (pp.I5I-2). On this important train of imagery the best possible gloss is supplied by Schopenhauer in a passage which probably contributed to Conrad's inspiration. In discussing the latent influence of Buddhism and other Oriental beliefs, Schopenhauer remarks:

We, on the contrary, now send the Brahmans English clergymen and evangelical linen-weavers to set them right out of sympathy, and to show them that they are created out of nothing, and ought thankfully to rejoice in the fact. But it is just the same as if we fired a bullet against a cliff. In India our religions will never take root. The ancient wisdom of the human race will not be displaced by what happened in Galilee. ${ }^{56}$

His remark comes as part of a plea for self-transcendence (which implies cultural transcendence as well), without which there is no knowledge of 
justice. 57 In "Autocracy and War" (I905) Conrad writes in a similar vein, that it is "our sympathetic imagination to which alone we can look for the ultimate triumph of concord and justice"; and the same essay reflects Schopenhauer's quietism in the well-known diagnosis it offers of empire building:

The intellectual stage of mankind being as yet in its infancy, and States, like most individuals, having but a feeble and imperfect consciousness of the worth and force of the inner life, the need of making their existence manifest to themselves is determined in the direction of physical activity ... Let us act lest we perish is the cry. And the only form of action open to a State can be of no other than aggressive nature. 58

An ability to see beyond the promptings of the appetitive and proselytizing will is the mark of maturity.

The characters in Heart of Darkness are distinguished, as has often been said, by the way they relate to their setting. On the one hand, there are the company agents who pass their time in a haze of self-absorption. Since nothing unconnected with personal gain is solid to them they lead a cut-throat existence unrelieved by either fellowship or compassion:

The only real feeling was a desire to get appointed to a trading-post where ... they could earn percentages. They intrigued and slandered and hated each other only on that account. (p.78)

Their favoured form of contact with the aborigines takes the form of firing blindly into the bush. Marlow stands apart from these "pilgrims" not only because of his ready sympathies but because he possesses from the first a sense of Africa as ageressively real - vested, indeed, with 
a stark immediacy that makes the pretences and daily business of the company, even memories of his own past, seem comparatively dream-like, surreal or farcical (pp.6I,76,78,93). Because Marlow often draws attention to the opacity of the setting it is easy to lose sight of this important characteristic. And though he repeatedly stresses his failure to understand what he sees (in itself a token of his rapt attention) such negative capability confers, in any case, a proper freedom on the things he presents. He puzzles, for example, over the function of the charm or keti (a device commented on by Burton in Central Africa) worn around the neck of the dying man whom he tends in the grove; and the matter is left in doubt until clarified in the account of the stoker (pp.67,98).59 Marlow, in short, learns to read the signs which he identifies as alien and this distinguishes nim from the other company men who remain locked, like the Aunt, in a world of their making. Even the "Harlequin", whose pure spirit of adventure is limited by narcissistic regard ("[he] enlarged my mind", p.I25), serves as a foil to those outgoing impulses which make Harlow in Conrad's judgement "a most discreet, understanding man". 60

Like Melville's narrator in Moby Dick, Narlow is blessed with a gift for assimilation and, like Ishmael again, he is arawn to the idea of a mysteriously unified world. A vision of kinship is the outcome of his journey; and his chief epiphany, which comes midway in the text, is inspired by the beating of drums. Earlier still he has reflected on the possibility that the nightly tattoos have "as profound a meaning as the sound of bells in a Christian country" (p.7I) and now he calls attention, again, to the apcarent indeterminacy of tribal custom ("whether it meant war, peace, or prayer we could not tell", p.95), even to an apparent 
discontinuity between Western and African life ("we were cut off ... we. could not understand"), before confessing to his involvement in the Dionysian scene:

If you were man enough you would admit to yourself that there was in you just the faintest trace of a response to the terrible frankness of that noise, a dim suspicion of there being a meaning in it which you - you so remote from the night of first ages could comprehend. $(\mathrm{p} .96)$

It is then that Marlow reports his insight into the far-reaching sources of the individual life:

And why not? The mind of man is capable of anything - because everything is in it, all the past as well as all the future. What was there after all? Joy, fear, sorrow, devotion, valour, rage who can tell? - but truth - truth stripped of its cloak of time. Let the fool gape and shudder - the man knows, and can look on without a wink. $(\mathrm{pp.96-7)}$

The acuity of Marlow's intuitive response is illustrated later when he alone of the crew rightly interprets the cry that rises from Kurtz's disappointed followers - though seemingly from the mist - as an expression of grief rather than anger. His clairvoyance is virtually complete when he senses that the howl of pain fits his own feeling of loss for Kurtz, whom he supposes dead (pp.I06-7, II4). From time to time Marlow may cling (as Ishmael does) to a work-a-day ethic but he never confuses protective belief with the truth ( 0.93$)$; and his extended sympathies are shown in his deep intuition of kinship with the dying helmsman (p.II9) as well as in his progressive understanding of Kurtz.

If Marlow corresponds, then, to the man who in Schopenhauer's scheme has lifted the veil of illusion, Kurtz, until the very last stage of his life, represents the principium individuationis, the fully embodied will. 
Because he succeeds in acting out that collective mind of which Marlow speaks, Kurtz engrosses every primitive trait and appears as the epitome of his "primeval" setting. "There is all Africa and her prodigies in us", Sir Thomas Browne wrote in Religio Medici (1643), reviving an already outmoded myth of correspondence: in Heart of Darkness Conrad founds a similar notion on the evolutionary premise that every organism has grown out of, and so contains, antecedent forms of life. From an essentially biological idea of continuity Conrad extrapolates wildly, like most thinkers of his time, and his assumption that Africa mirrors a remote stage in the development of European civilization is in every way inadmissable. It is worth recognizing, however, that at a period when fricans were generally (and perhaps increasingly) seen as a race apart, Conrad's stress on underlying kinship amounted to a restatement of the abolitionist's slogan, "Am I not a man and a brother?". 6I But the terms, of course, were different. In place of a myriad reflections of the Divine Image Conrad proposes a brotherhood based on a nature red in tooth and claw. No-one would mistake Kurtz for the type of sociable man. He comes close, after all, to murdering his only confidant for a small supply of ivory, and voracity is the clue to every department of his life, as witnessed by his remark, "Niy Intended, my station, my career" (p.I47). Where Marlow, true to Schopenhauer's contemplative man, abstracts from the particular in his search for a "truth stripped of its cloak of time" ( $p .97)$, Kurtz behaves like the prisoner of will who "regards his person as absolutely different and separated by a wide gulf from all others". 62 His internal struggles correspond, moreover, to the philosopher's picture of the "inward horror" that overtakes the man who asserts himself "to the absolute denial of the same will appearing in other individuals". 3 what men have in common, however, is not necessarily what enables them to 
relate, and it is the rational virtue of restraint, enshrined in Marlow's cannibal crew, that Conrad in a most complex exposition (traced definitively by watt) celebrates as the ground of civility. 64

Marlow and Kurtz represent opposite nodes of experience and the worlds they inhabit are texturally distinct. Self-knowledge, in the classical sense, is Marlow's aim (p.I50) and he is associated throughout with the faculty of sight: "do you see?", he demands of his listeners, and he conceives his relation to Kurtz as that of a man peering into a dark abyss (pp.82-3, I49). More Judaic than Marlow, Kurtz is concerned to be rather than to know. His rage for expression is linked with the auditory and vocal ("He was ... a voice", pp.II3-I5); his life aptly summed up in the phrase, "He said it" (p.I5I). The polarity is complicated, however, by the fact that Marlow in the course of his self-exploration embraces those "forgotten and brutal instincts" which are alive in Kurtz (p.I44). Indeed, Marlow encloses Kurtz and this sense is rendered texturally through the way he himself, in telling the story, becomes a voice speaking out of dariness (p.83). Again, because Marlow's approach to Kurtz and his growing awareness of the wilderness are two faces of a single thing - his penetration of that hidden "mind of man" - it is unsurprising that the same imagery attaches to each. Marlow when he first sees the coast catches "an air of whispering" ( $p$. 60), and this fancy, thrown back by the wilderness ( $p . I 3 I$ ), becomes at length a trait of Kurtz, who is all voice, or whisper (pp.II3,I5I,I59). In much the same way the ambivalence that Marlow attributes to his surroundings ("smiling, frowning", "grand, mean", p.60) carries over into his intuitions of Kurtz who is "an angel or a fiend", "an appeal or ... a menace" (pp.8I, II4). Kurtz might be said to voice his setting, if Marlow did not remind us at times that he is something of a ventriloquist. 
Holding beliefs about the unknown, he once suggests, is comparable to peopling Mars with creatures who walk on all-fours (pp.8I-2). Marlow is well on the way to creating Kurtz before they meet, and the truth of his projections is guaranteed by the "mind of man", by an underlying uniformity in nature - a bald abstraction, true enough, but one brought to life in Conrad's treatment of the setting. And a single setting it is that envelops the action. The closing paragraph clinches a general awareness that one watercourse stretches from Gravesend to the heart of Africa, and, taking homogeneity still further, Marlow frequently compares the jungle, in its invasive and procrustean aspects, to the sea (pp.86,92,I56). Encoded in the solemn opening with its insistence on the illimitable ("an interminable waterway", "vanishing flatness") and indifferentiable ("the sea and the sky were welded together without a joint") is the promise of a narrative in which boundaries will steadily dissolve.

Marlow's inner adventures are not conveyed analytically. Rather they are evoked through a symbolic mode appropriate to the inscrutable depths in which Heart of Darkness deals. One device which Conrad employs to link Marlow with Kurtz is that of the double. Much in the way that Scrooge in A Christmas Carol (1843) finds the face of his old partner Marley in his frontdoor knocker, Marlow on ringing the doorbell on his visit to the Intended, sees Kurtz staring at him out of the glassy panel; and the apparition, or reflection, immediately follows his attempt to suppress "all that remained of him with me" (pp.I56,I55).65 Earlier he has found himself so closely involved in Kurtz's illness that he narrowly escapes a similar fate: "the pilgrims buried something in a muddy bole. And then they very nearly buried me" (p.I50). The tie between the two of them goes back to the fact that they are paired by 
the other company agents as alarmingly honest and influential men. Noting this, Marlow - despite his hatred of deceit-lies for Kurtz; and shortly afterwards Conrad sustains an ambiguity that leaves a momentary doubt as to which of them is to be the victim of the Manager's murderous schemes $(p .89)$

It is formal pointers such as these that alert the reader to the common ground that is increasingly cleared between Marlow and Kurtz. Given the nature of his theme Conrad's dramatizations are often wonderfully light in touch. Cannibalism is among the uglier traits attaching to Kurtz, who opens his wide mouth "as though he had wanted to swallow all the air, all the earth, all the men before him" (pp.I34 and I55) - the simile leads irresistibly to further dark thoughts about the "unspeakable rites" (p.II8).66 It is a comic moment, on the other hand, at which Marlow, wondering what can restrain the starving crew, first appraises the "pilgrims" and then himself from a fresh angle:

it occurred to me I might be eaten by them before very long, though I own to you that just then I perceived - in a new light, as it were - how unwholesome the pilgrims looked, and I hoped, yes, I positively hoped, that my aspect was not so - what shall I say? so - unappetizing.

How exactly right it is that Narlow should turn cannibal only in regard to his eyes.

Perhaps the most taxing problem posed by Heart of Darkness lies in the relation between Conrad's attitude to the Congo Free State and his attitude to Kurtz. We move from the exposure of a horrendous social evil to a figure who, though deeply implicated, is sufficiently magnetic to have convinced many readers that he is a hero. Part of Kurtz's function, of course, is to supply a moral index. His frank impiety serves to strip 
away the bogus pretences of a company whose motives and procedures are in the last analysis as brutal. But he emerges also, troublingly, as a fund of energy - as a "devil", granted, but of a fiery rather than flabby variety $(p \cdot 65)$. Even if we allow that his glamour has sometimes been overdone - at his entrance on a stretcher he is "appalling", "atrocious", "pitiful" - he does lend, the fact remains, a natural aspect to iniquity. That Conrad meant this to be so, and that he was aware of the sting in the tail of his story is pretty clear from a comment he made to Cunninghame Graham after the appearance of the first of the three instalments: "So far the note struck chimes in with your convictions - mais après? There is an après." 67 when the reality of Leopold's rule became public, there were those who sought to pass off the affair as a hideous accident - the result of a particular conjunction of laws in an unfortunate "system of government"; for others, like Conrad, and later Keir Hardie, the Congo Free State yieided "an image of the whole past of the human race". 68

Conrad dwells on the naturalness of evil, however, only to insist that nature is not enough. In common with many writers who absorbed the impact of evolutionary theory he sees that physis and nomos are essentially disjunct, and is determined to show that human ideals exist in defiance of what man, by instinct, is. His view matches that expressed by Huxley in the Romanes Lectures:

Let us understand, once for all, that the ethical progress of society depends, not on imitating the cosmic process, still less in running away from it, but in combating it. 69

It is no surprise, then, to find that although Marlow responds to a deep vitality in Kurtz, he honours him solely for the strenuousness of his struggle with himself, and for the judgement implied in his last 
words, "The horror! The horror!" ( pp.I45,I47;I49,I57). The Kurtz who finally comes in for celebration is the contemplative figure whose dying insight comprises a symbolic, if unavailing, "moral victory" (p.I5I).

To drive home the creative status of moral principle, Conrad resorts in the closing pages of Heart of Darkness to a ploy similar to that used by Vilde in his witty riposte to naturalism, "The Decay of Lying" (I889), when he has Marlow lie to the Intended in order to save "that great and saving illusion" which is her innocence (p.I59). 70 But although ignorance provides one way of transcending the material truth, it does not, as the easy collapse of Kurtz's original idealism shows, provide the best way of combating it. And so, even while Marlow acknowledges the value of cloistered belief ("lest [our world] gets worse", p.II5), he gently indicates that the Intended, like Kurtz before her, is the prisoner of an egocentric will:

I pulled myself together and spoke slowly. "The last word he pronounced was - your narne."

I heard a light sigh and then my heart stood still, stopped dead short by an exulting and terrible cry, by the cry of inconceivable triumph and of unspeakable pain. "I knew it - I was sure:" (pp.I6I-2, my italics)

It is a choice of nightmares that leads Marlow to stand by Kurtz, but the choice Conrad offers his readers is a less distressing one, for Marlow's contemplation is of a kind that sharpens understanding of the world, and he remains, despite his disillusionment, a man who can both act and know.

Of the great novelists Conrad was the last who could claim to be something of an explorer, and it is with a fair degree of truth that he 
presents himself, in an essay written towards the end of his life, as having outlived the era of exploration. The undiscovered places, he observes there with evident nostalgia, "have vanished as utterly as the smoke of the travellers' camp fires in the icy night air of the Gobi Desert". 7 I

After Conrad, novelists dealing in the encounter with unknown places were mainly to rely on historical settings. Somerset Maugham in The Explorer ( 1907 ), a novel which hinges on a reworking of the last scene in Heart of Darkness, opts for the Africa known to Burton and Stanley. ${ }^{72}$ There was otherwise a tendency to fall back on very vaguely located settings as Conan Doyle does, for example, in his ingeniously literal treatment of a return to the past in The Lost World (I9IO). Altogether apt but lucky is E.M. Forster's choice in A Passage to India (I924) of a specific setting which happens to qualify. If Moby Dick represents terra incognita on the move, the Barabar hills comprise a fossil form: rock so ancient as to suggest "flesh of the sun's flesh" enfolds pockets of inner emptiness "sealed up before the creation of pestilence or treasure". 73 As the century advances, however, the remaining frontiers of earth and ocean become fewer as well as more specialized; while science fiction - at least in its more popular forms - steadily stales those belonging to the future. For the most part the explorer finds his base in the historical novel, and of this territory Patrick White has proved himself the genius.

These, then, on a straightforward view, are the chief directions taken in the twentieth century by the novel of exploration. It is worth noticing, all the same, that the kind has a separate issue in many of the masterpieces of modernism. The link is provided by a shared interest in inner exploration, in producing the hidden man. While it 
would be naive to suggest that when the fund of exotic places ran low writers turned to the novel instead, it is the case, nonetheless, that the special concern of a work like Heart of Darkness - Marlow's search for the mind of man ("everything is in it, all the past as well as all the future") - persists almost unchanged into a fiction that is comparatively plotless and domestic. Although Conrad's text was undoubtedly influential the notion of a collective mind gathered impetus, of course, quite independently of it. D.H. Lawrence spoke for many when he hailed Freud, in a resounding Homeric simile, as a "supreme explorer". 74 Belief in the unconscious as something delimitable or reclaimable like land, became standard, and its growth, as of much else in the modern period, can be traced back to the seeds of evolutionary theory. Though less thorough-going than Jung who thought that his patients reproduced "in every detail the myths, cosmogonies and primitive conceptions of the early ages of man", Freud raised elaborate theories of developrent - relating narcissism to the "animistic phase", and so forth - on the assumption that each individual re-enacts the stages of cultural life, or that "ontogeny recapitulates phylogeny" as the biologists had it. 75 While the competitive aspects of Darrin's theory, deriving historically from Nal thus, were taken up by Nietzsche and by Marx (who once remarked that The Origin of Species (I859) served him "as a natural scientific basis for the class-struggle"), the notion of an all-inclusive, unconscious mind seems to have been precipitated by the idea of all creation sharing in a common ancestry. 76

Myths of correspondence have always appealed to the imagination and writers in the early decades of the century were only too eager to find terms and expressive means for the newly sanctioned Ineinsbildung. So 
it is that Lawrence in his famous letter to Garnett speaks of his desire to break away from the "stable ego" and deal instead with the elemental substrate that sustains the various "allotropes" of character; 77 that T.S. Eliot in The Waste Land has Tiresias, the androgynous seer, "unite" all the other figures in the poem; 78 that Virginia. Noolf in To the Lighthouse relates the "wedge-shaped core of darkness" that stands for Mrs Ramsey's unrealized self to the "triangular purple shape" which Lily Briscoe, the artist, aims to portray; ${ }^{79}$ or that James Joyce in Ulysses develops the theme of "all in all ô us" with its corollary of the self meeting the self in the other, and makes over Finnegan's Wake to the dream of Here Comes Everybody. 80

In the work of these writers there are many allusions to Conrad's great novella, which more decisively, perhaps, than any other single text, heralds the advent of modernism. Particularly resonant, in this respect, is the imagery of tropical Africa which, while it provides a literal analogue to Marlow's inner nature in Heart of Darkness, later becomes a metaphor or sign for the instinctual life. The shift is already visible in Henry James's story the Beast in the Jungle (1903) where a hero who pictures some future achievement in terms of the title's heroic image and evades, on this excuse, sexual commitment to the woman he might love, learns too late that what the jungle truly denotes is the heart, from which he is never more estranged than on his travels in the tropics. From this it is a short step to the language of the rain-forest and nucleolating dark that Lawrence uses in The Rainbow (I9I5), after Skrebensky's return from Africa, to give substance to the regenerative forces of the blood. In the same novel he borrows an idea from Heart of Darkness to express his sense of the quicker man 
that lies buried in each citizen:

He was out in the wilderness, alone with her. Having occasion to go to London, he marvelled, as he returned, thinking of naked, lurking savages on an island, how these had built up and created the great mass of Oxford Street or Piccadilly. How had helpless savages, running with their spears on the riverside, after fish, how had they come to rear up this great London, the ponderous, massive, ugly superstructure of a world of man upon a world of nature! $8 \mathrm{I}$

We have seen how a concern with man's underlying nature recurs in novels about exploration, and to this vibrant account of it Marlow, for all his wariness, had led the way. 
The Country of the Mind:

Exploration as metaphor in Voss

Sidney Nolan, to whom Patrick White dedicated his künstler-roman The Vivisector, created in his series on Kelly a pictorial enblem that can readily be identified (alongside the documentary accounts of Leichhardt and other explorers) as a source of inspiration for Voss. I Ned Kelly, the plucky outlaw who played God to the colony of Victoria, figures, in Nolan's expressionist paintings, as a stark netallic centaur presiding over the outback. Through Kelly's grid-like head (which conveys the impression that he simultaneously faces inland and looks back) the spectator sees, in place of eyes, the desert or sky that lie beyond. In Voss (I957) ihite repeatedly presents his hero, like Ned Kelly, as a frame to the space through which he advances. Voss's eyes, "light-coloured" or "infinite blue", provide a disconcerting lack of resistance to the gazer. ${ }^{2}$ To Mr Bonner who "would never stray far beyond familiar objects" Voss remains unfathomed, "lost to sight in his [eyes], as birds are in sky" (p.20); while to Laura who "might have sunk deeper than she had at first allowed herself into the peculiarly pale eyes" ( $\mathrm{p} .2 \mathrm{I})$, surrender to the unfathomable exists as a potential from the start. Even as narrator white succeeds in sustaining the pictorial emblem without any noticeable loss of realism. Voss is seen to hold the landscape in his eyes, either by reflection or through the fullness of his gaze:

Seated on his horse and intent on inner matters, he would stare imperiously over the heads of men, possessing the whole country with his eyes. In those eyes the hills and valleys lay still, 
but expectant, or responded in ripoles of leaf and grass, dutifully, to their bridegroom the sun, till all vision overflowed with the liquid gold of complete union. (p.I65)

Through this double exposure of mind and landscape, White points to that equation of spatial and psychological exploration which generates the form of Voss and finds a compressed statement towards the novel's close: knowledge comes of torture in the "country of the mind" $(\mathrm{p} .475)$.

That the narrative of Voss's exploration serves as an analogue to inner disclosure has been noted by several critics. In an early but perceptive monograph R.F. Erissenden observed that it was White's intention to "cut through to the spiritual centre ... just as ... his hero struggles towards the geographical centre of the continent". 3 Nore recently Brian Kiernan has commented on White's deployment of "the romantic voyage of discovery as an exploration of the self", and called attention to the "structural metaphor" of the novel by tracing the correspondences that develop between the experience of the expeditionary party, and of those who remain behind in Sydney, principally Laura but also Willie Pringle and Belle. ${ }^{4}$ What I shall concentrate on are the meanings that white encodes on the concrete side of his extended and largely concealed metaphor - the meanings that he derives, in fact, from his treatment of landscape. The expressive value of the many plastic codes through which the central conflicts of the novel develop have not had, I believe, their proper share of attention. 
Laura, we are told at the novel's start, has been suffocated by the "fuzz of faith":

She did beliove, however, most palpably, in wood, with the reflections in it, and in clear daylight, and in water. (p.II)

She provides a valuable guide to the text itself when in the closing pages she counsels the group of aspiring spirits gathered about her "to interpret the ideas embodied in the less communicative forms of matter, such as rock, wood, metal, and water" (p.475). We have only to recall a widespread textural preoccupation of the novel - the metamorphosis of stone into flesh, and of living forms into vegetation - to realize that the dreams and hallucinations which Voss experiences in the desert are given a significance that goes beyond his own, highly idiosyncratic, case. Around his central equation White builds up, by degrees, a language of sense that enables him (more fully perhaps than he realizes at times) to transmit the issues of psychological and ethical debate through the very landscape that his explorer perceives and half-creates. Because they unfold stage by stage, the procedures which generate the grammar of this language require gradual analysis.

At the start of Voss White establishes the co-ordinates of the exploratory metaphor through a series of muted comparisons relating inwardness to space. Hence Voss is reported "happiest in silence, which is immeasurable, like distance, and the potentialities of self"; or again, coaxed into social response, he gestures "out of that great distance to which he was so often withdrawn" $(p 0.24,34)$. 
The contrast between the silence that Voss shares with Laura (also "happiest shut with her own thoughts", p.9) and the stupor of self-satisfaction that prevails at the Bonners' meal is paralleled by the opposing attitudes towards the outback shown at the table, where indifference to Voss's quest is associated with a careless neglect of inner reality:

"Of course," said Mrs Bonner, who loved all golden pastrywork, and especially when a scent of cloves was rising from it. "Nor did we really have time to understand Mr Voss." "Laura did," said Belle. "Tell us about him, Lolly. What is he like?"

"I do not know," said Laura Trevelyan.

I do not know Laura, Mrs Bonner realised.

The Palethorpes coughed, and rearranged the goblets out of which they had gratefully sipped their wine. Then a silence fell amongst the flakes of pastry.

True, it is at Laura's expense that the first equation of dreams with the interior is made:

she was also afraid of the country ... But this fear, like certain dreams, was something to which she would never have admitted.

$(\mathrm{p} . \mathrm{I} 3)$

But she is at least ready, after her first meeting with Voss, to admit to her fear of the inland and to generalize from it:

"Everyone is still afraid, or most of us, of this country, and will not say it. We are not yet possessed of understanding." $(p \cdot 3 I)$

In defending Voss, Laura affirms the value of introspection, and 
in doing so she offends the company gathered at the Bonners' table who retaliate with parochial complicity: "she was of the same base metal as the German" $(p \cdot 32) .^{5}$

Voss's commitment to the desert and Laura's equivalent commitment, her willed intimacy with Voss and, after his departure, with her emancipist servant Rose (each of whom holds up to her the challenge of a desert; pp.94,80-I), represent diverse if convergent quests, yet they provoke from Sydney society a similar reaction since both involve the realization of an uncovenanted self. At the Pringles' picnic where Laura and Voss are identified as "sticks", there is little to choose, in the eyes of their mercenary host, between dreams and unprofitable land:

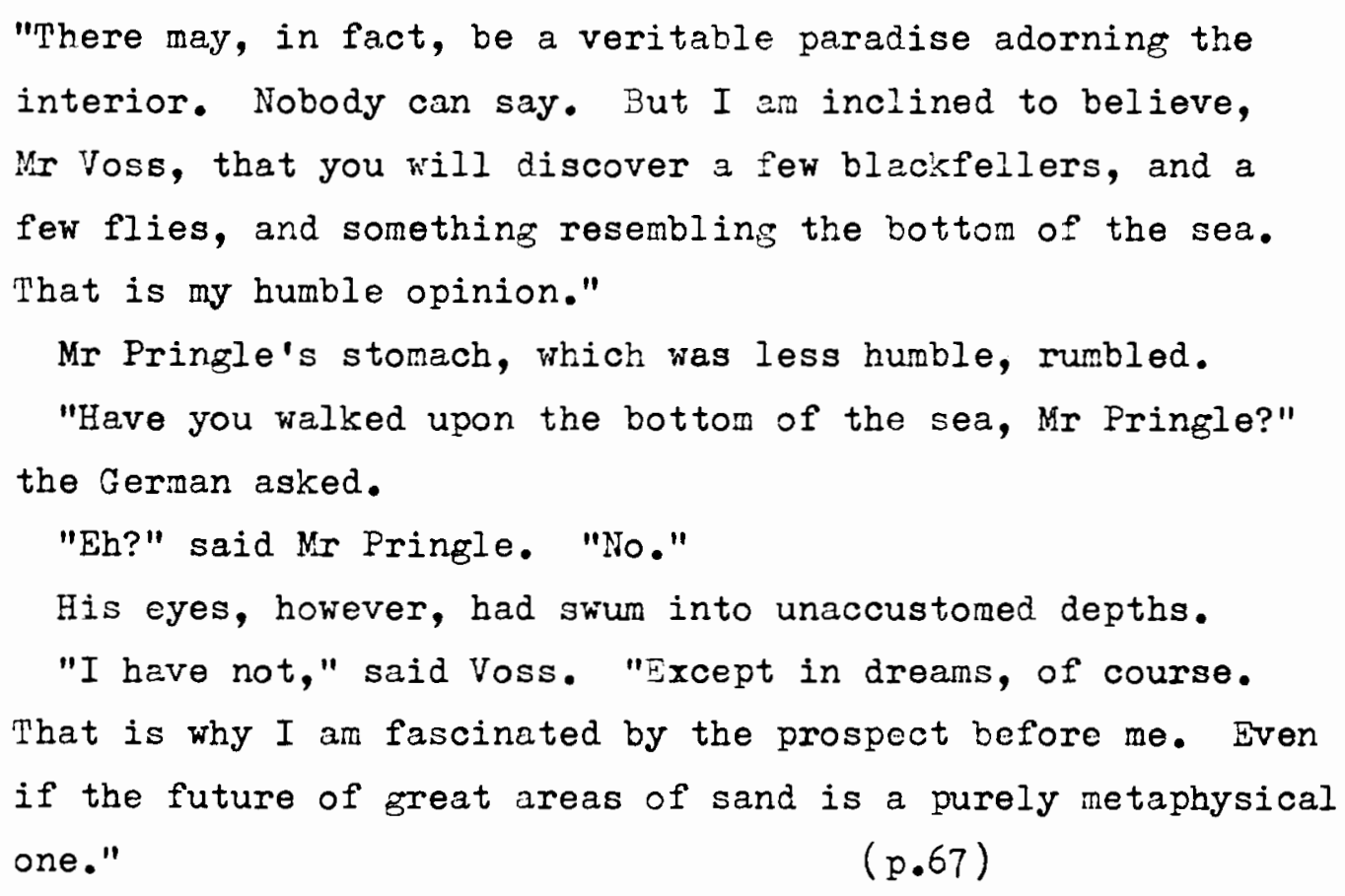

Mr Pringle's stomach, which was less humble, rumbled. "Have you walked upon the bottom of the sea, Mr Pringle?" the German asked.

"Eh?" said Mr Pringle. "No."

His eyes, however, had swum into unaccustomed depths.

"I have not," said Voss. "Except in dreams, of course. That is why I am fascinated by the prospect before me. Even if the future of great areas of sand is a purely metaphysical one." (p.67)

Truth is not a valued commodity in the Bonners' world. It necessarily conflicts with Mr Bonner's determination to render 
himself "safe ... from attack by life" or with Mrs Bonner's self-protecting "upholstery" which extends even to the euphemisms in which she swathes all reference to sex and death (pp.372,I2). Although wonderfully acid, White's satiric treatment of prosperous Sydney seldom lacks good-humour. It spells out, all the same, a constrictive milieu in which cultural aspirations are ignored or reduced to a show and in which feelings are acknowledged only when they coincide with form. Alienation from such a society carries the possibility of grace.

Voss himself is never wholly exempt from the play of White's comedy and we intermittently view his self-confidence as a blank but unhonourable cheque - notably at the moment that Mr Bonner produces the scarcely charted map:

"The map?" said Voss. It was certainly a vast dream from which he had wakened. (p.26)

But Voss's desire to "attempt the infinite" holds the promise of a life richer than one "choked with the trivialities of daily existence" (p.38); and the social context delineated in the first part of the novel accordingly enforces an ambivalent estimate of his arrogance. We side with Laura's view that arrogance is the quality that "just saves him, terrible though it is" (p.78). The "simplicity and sincerity" that underlie it (p.26) are clearly evident in the reasons he gives Le Mesurier for joining him:

"Every man has a genius, though it is not always discoverable ... But in this disturbing country, so far as I have become 
acquainted with it already, it is possible more easily to discard the inessential and to attempt the infinite ... you will realise that genius of which you sometimes suspect you are possessed, and of which you will not tell ne you are afraid."

$(\mathrm{pp} .38-9)$

The expedition is founded on a faith in undisclosed resources of human potential; and the desert is the symbol of this dream before it proves its actual setting.

Among the visionary jottings in the notebook that represents his fulfilment Le Mesurier distils the most concentrated statement of tho exploratory metaphor:

We do not meet but in distances, and dreams are the distance brought close.

Patrick White may not uphold any systematic belief in the collective unconscious, but this statement does point to the way in which the movement through the desert is accompanied, on the part of the central characters at least, not only by a growing awareness of what has been hidden but also by a progressive disclosure of unaninity. The almost clairvoyant relationship that develops between Laura and Voss provides White with one means of dranatizing this "meeting in distance", his application of a fairly homogeneous symbolio scheme another. The correspondence between geographic and psychic penetration accounts for the growing dominance of an expressionistic mode in which the "world of dream" weighs equally with the "world of semblance". The image in which White expresses this oscillation between the internal and external - the opening and closing of a 
butterfly's wing $(p .277)$ - lends itself to the narrative switches which prevail in the later part of the novel, not only to the alternation of Sydney with the desert but, within each of these settings, to the parity bestowed by the narrator on the hallucinatory and the real. Voss's recreations of Laura's presence, for example, are given the same status as the events of the present:

Voss, Palfreyman, and Laura continued to walk towards the cave. The selflessness of the other two nas a terrible temptation to the German.

The novel becomes, to put it crudely, more modernist as the narrative proceeds; and Wite, if perhaps only unconsciously, reinforces this stylistic shift with a chronolozical succession of literary reminiscence. So the first chapter of the novel shares its situation rith the first chapter of The Europeans (I878) - the young lady of the house while her family are at church offers a glass of wine to the young man who arrives unexpectedly from afar; and Rose Portion's story in the fourth chapter - she has been transported after conviction for the murder of her illegitimate child - echoes Hotty Sorel's history from Adam Bede (I859). Reminiscences of Henry James and George Eliot yield, however, to something closer to Tennessee Nilliams' The Glass Menagerie (I945) when we come to the account of Falfreyman's sister, the deformed girl who cherishes images of crystalline perfection, an account that leads to the heart of Voss's torment.

In accordance, then, with a trajectory that at once penetrates outer and inner space, the narrative increasingly transcends the 
historical distance of its sotting. Before we trace Voss's discovery of "the country of the mind" we need to return, however, to the novel's social matrix. For the two chief, and allied expressions of Voss's development - the sequence of his presented dreams, and his creation of Laura - are given significance by the peculiar estrangement which he suffers prior to setting out. It proves, indeed, to be a psychologically as well as socially entrenched state that finds release in the ever more animated landscape that tells his change of heart.

The claustrophobia which repeatedly overwhelms Voss in the opening chapters testifies in part to the stuffiness of the Sydney ambience. Under bombardment in the Bonners' drawing-room, swaying on his legs and "almost crazed by people", Voss experiences a desire to be at large which we are encouraged to respect:

Deadly rocks through some perversity, inspired him with fresh life. He went on with the breath of life in his lungs. But words, even of benevolence and patronage, even when they fell wide, would leave him half-dead.

That asylum from unmentionable realities, the padded carriage from which he tears an exit on returning from the Pringles' picnic, again legitimizes his need for escape. We learn, however, that his fear of enclosure is more deep-seated - that it is often tantamount, in fact, to retreat. A revulsion from the "palpitating bodies of men" determines, for example, his chango from medicine to botany as a student in Germany (p.I6). It is, again, a suspect notion of freedom that prompts him to "tread with his boot upon the trusting 
face of the old man, his father" (p.I6), and sever all ties with his family whose image continues to threaten across the world:

He smelled the stovy air of old, winter houses, and flesh of human relationships, a dreadful, cloying tyranny, to which he was succumbing.

Voss's mission is inspired, in short, by a dread of intimacy, and the compensatory nature of his venture inland emerges in the telling phrase: "I have every intention to know it with my heart" (p.36). In common with Palfreyman who, it later turns out, has sought the desert to escape the recognition that he cannot save his sister, Voss seeks the oblivion as well as the challenge of the unknown. Propelled as much by his recoil from human need as by an ambition to realize his genius in the wilderness, Voss like Nolan's Kelly - looks both forwards and back. ${ }^{6}$ An urge to defuse all challenging relationships consigns him to a figurative waste long before the expedition sets out, and the splendours of "solitary travel" continue to appeal even after the party has been settled (p.I33). His pride appears, too, in the way he retires into a private "world of desert and dreams" the better to relish "the illusion" of his own strength $(p p .29,75)$.

The hint of pathological flight is concealed from Voss by the trappings of transcendental philosophy in which he clothes his quest. His utterances on the supremacy of the will have been ascribed (despite obvious anachronism, for the novel is set in I848) to the influence of Friedrich Nietzsche but they belong rather, as their peculiarly ascetic bias shows, to a romantic strain 
of German idealism. Voss's belief that a gratuitous act of will can disclose a source of Divine Power ( pp.95-6), and his concomitant contempt for unbelief ("Atheismus is self-murder") are consonant with Fichte who in his Vocation of Man identified will as the key to the noumenal world, and celebrated its autonomy:

the sensuous life of every finite being points toward a higher life, into which the will, by itself alone, may open the way ... My will, directed by no foreign agency in the order of the supersensual world but by myself alone, is this source of true life, and of eternity ... The will rejects absolutely all earthly purposes, all purposes lying outside itself, and recognizes itself, for its own sake, as its own ultimate end. 7

The maxim, "To make yourself, it is also necessary to destroy yourself" that Voss addresses to Le Mesurier - who excuses himself by disclaiming such heights ("I shall wallow a little in the gutter, I expect, look at the stars from a distance, then turn over", p.38) - is in keeping with Fichte's pronouncemerts on dying into life through a sacrifice of "the sensuous and all its objects", a sacrifice undertaken as a categoricel act of will:

By this renunciation of what is earthly, faith in the Eternal first arises in our soul, and is there enshrined apart, as the only support to which we can cling after we have given up all else, as the only animating principle that can elevate our minds and inspire our lives. We must indeed, according to the figure of the sacred doctrine, first "die unto the world and be born again, before we can enter the kingdom of God". 8

In this life-denying creed of aspiration, Voss masks his dread of 
human relationships. His ideal of self-sufficiency, his creation of an unassailable identity, that of the explorer attempting the infinite, derives from weakness as much as from intransigence. And though, given the limitations of the community in which he finds himself, his refusal to compromise takes on value, it never amounts to more than a preliminary condition of his development. Laura recognizes this when she sees, at different times, that if Voss is saved by his arrogance he is also damned by his pride (pp.78,96). Accordingly, in terms of the theological scheme stated towards the novel's close, Voss's self-exaltation comprises merely the starting point of "the three stages": "Of God into man. Man. And man returning into God"(p.4II). His idea of dying into life, appropriated from the zeitgeist, receives a broader and more traditional treatment at the hands of Patrick White, for it is through recognition of his frailty that Voss vill ascend ( $p .4 I I)$, and through failing to achieve success as an explorer that he will experience "the nystery of life" ( $p .289)$. $^{9}$ The dostiny and identity that Voss has chosen for himself are set, from the very first, on a collision course. To the petulant protest of the man who has deified himself - "I detest humility ... Is man so ignoble that he must lie in the dust, like worms?" (D.I6I) - the desert has its answer, and what Voss the romantic isolato discovers there, even if that discovery takes place largely in solitude, is the self in relation. It is through the erosion of the adamantine self that inspires, and continues to inspire his progress, that Voss finds grace. 
Almost from the start Voss images bis intransigence as crystalline and mineral, and the association is reinforced by bis contrastive alignment of love with all that is "soft and yielding", "easily burt" and thus to be evaded (p.45). In his first recorded dream we see him seeking assurance that the identity he has elected for himself is proof against the claims of others:

It was not possible really, that anyone could damage the Idea, however much they scratched at it. Some vomited words. Some coughed up their dry souls in reboundine pea-pellets. To no earthly avail. Out of that sand, through which his own feet, with reverence for velvet, had begun to pay homage, rose the Idea, its granite monolith untouched. Except by Palfreyman was it? He could not distinguish the face, but the presence was pervading the whole dream. And now Voss was stirring on his straight bed. It was a humid night. His hands were atterpting to free his body from the sweat with which it had been fastened.

To Voss who compares his strength to "the power of rock or fire" (p.67) the 1gneous monolith, combining homogeneity with the utmost recalcitrance, is the apt symbol of his willed identity. (The self-dependence of Laura and of Judd are by contrast those, respectively, of marble and oolitic stone, pp.9,I45 .) Palfreyman whom Voss has identified as an apostle of humility figures accordingly in his dream as an appropriate challenger to the supremacy of the Idea, to the extent that Voss is stirred from his sleep and, as the self-reflexive construction indicates, vainly attempts to free his body from self-induced bondage. 
The debate between pride and humility is first fully joined when Voss, shrinking again from the "soft and defanceless", fends off Laura's solicitude at the Bonners' party:

"Ah, the humility, the humility! This is what I find so particularly loathsome. My God, besides, is above bumility." "Ah," she said. "Now I understand."

It was clear. She saw him standing in the glare of his own brilliant desert. Of course, He was Himself indestructible. And she did then begin to pity him. She no longer pitied berself, as she had for many weeks in the house of her uncle, whose unfailingly benevolent materialism encouraged the practice of self-pity. Love seemed to return to her with humility. (p.96)

Hectic in isolated quotation, this statement evolves out of the sensuous details of a minutely realized scene in which shifting states of mind are dramatized through the perceived textural contrasts between the crystaline and the yielding, between stone and flesh. A dish of jellied quinces hardens under Voss's gaze into a group of garnets and pale jade lozenges ( .89$)$, while the reverse transformation is effected through the eyes of Laura: "Miss Hollier's garnet brooch [seemed] edible, like the quinces"( pp.88-9). Mrs Bonner's concern to preside over her fuests rather than liberate them provides a parody of Voss's obsession with fixity:

Mrs Bonner, however, was creating groups of statuary. This was her strength, to coax out of flesh the marble that is hidden in it. So her guests became transfixed upon the furniture. Then Mrs Bonner, having control, was almost happy. 
Radclyffe sings to her with such intersity that the glass ornaments begin to rattle, and Belle is then seen as an embodiment of that capacity for merging whick enables love:

Now [she] was neither flesh nor marble. She was enveloped in, and had herself become, a cloud of the most assiduous tenderness. To have remained in such a trance, of cloud wrapping cloud, would have been perpetual bliss. (p.9I)

It is Belle's presence that causes Voss to suffer a pang for what he has put behind him, but he swiftly translates his sexual desire into a nostalgia for the German summer with its flowing rivers and brilliant trees ( $p .(7)$; and to just such a landscape he finds himself transported when he arrives at the Sandersons' farm, appropriately named Rhine Towers. What first impress him there are the mineral-like aspects of the scenc ("veins of silver loomed in the gullies, knobs of amethyst and sapphire glowed on the hills", p.I37) but it is ultimately the flowing movements of the light that overwhelm him until alarm at his access of feeling causes him to rein back

He had been wrong to surrender to sensuous delights, and must now suffer accordingly.

With a sweeping gesture of self-punishmont he attempts to sabotage the Sandersons' hospitality by insisting that his men sleep out of doors.

The dream of which Voss remains largely unconscious on waking to his first morning at Fhine Towers (he is grateful for the bed) provides the only transition between his perfunctory leave-taking 
of Laura on the Sydney quay and the letter, written before he leaves for Jildra, in which he proposes marriage. Since it reveals his condition before setting off, and marks out the decisive forces in the conflict that lies ahead, this, the first of Voss's dreams to be presented in any detail, asks for close attention.

Going to bed in the best room the Sandersons could offer, between exquisitely clean sheets and a lingering scent of verbena, Voss was not long with his body, and those thoughts which had been buzzing like blowflies in his head. At once the hills were onfolding him. All that he had observed, now survived by touch. So he was touching those same hills and was not surprised at their suave flesh. That which would have been reprehensible, nauseating, frightening in life, was permissible, even desirable, in sleep. And could solve, as well as dis-solve. He took the hand to read it out aloud, whatever might be printed on it. Here there were hills, too. They would not be gone around. That is the hill of love, his voice said, as if it had been most natural. That, she pointed, was burnt in the fire of the kiln as I pushed the clay in, and, insignificant though it is, will show for life. Then, roughly, he threw away the hand, which broke into pieces. Even in dreams he was deceived by the appearance of things, and had taken the wrong hand. Here it is, she said without grudge, and brought him another, which had not been baked. It was of white grain. It still had, most terribly, most poignantly, its semblance of flesh. So he shut it up in his bosom. He was afraid to look at it again. Till she bent down from her horse. The woman with the thumping breasts, who had almost got trampled, and whose teeth had been currying black horsehair, began to shouts Laura, Laura. For assistance. All that happens, happens in spite of the horsehair woman, who is, in fact, stuffed. Laura is smiling. They are sharing this knowledge. Then, how are names lost, 
which the hands have known by touch, and faces, like laborious, raw jugs? Laura is the name. But the name, all is lost, the veil is blowing, the wind. Is it not the same stuff with which the hills are shrouded, and of which the white word is, ach, Musselin, natürlich, but what else? (p.I49)

In a study of the motives of fictive adventurers Paul Zweig comments on the frequency with which an initial flight from women leads to a rediscovery and reassertion of feminine values in the wilderness. Io True to this pattern, Voss, who has austerely deflected his desires into the landscape, now unravels this process in his dream, turning stone back into flesh, as Laura materializes - however disjointedly from the desert. The suave flesh of the hills manifests the capacity for love that Voss has suppressed, and shows up the element of compensation in his trek. His sudden surrender to sleep recalls the earlier occasion on which he "fell, straight, deeply into himself" to find comfort in his dream of the Idea as an untouchable monolith, but the sense of secure possession imaged there is now held at risk by a switch of agency, for it is the landscape that is now doing the touching ("At once the hills were enfolding him"), and yet his confidence survives the change into flesh ("So he was touching those same hills and was not surprised at their suave flesh"). Voss in his sleep is relieved by the expression of $a$ desire which remains threatening to him in life, but protected too by the censorship that is available to him even in his dream, and in this sense the images of his unconscious can "solve, as well as dis-solve". He accepts the offered hand only conditionally, "to read it out aloud, whatever might be printed on it", and on the palm finds evidence of an 
independent destiny. Not lixing this, he distances himself by returning the hand to the realm of the natural - the language of palmistry offers a latent pun (on "mons") that assists the tronsformation: "Fere there were hills, too. They would not be gone around." But the restatement only stresses that love, a.s Laura has already said, is more demanding than landscape. Voss appears reluctent, however, to avoid the hill of love for he allows Laura to offer him two further hands. II Made of fired clay, the first of these is in keeping with the terture of the landscape and Voss's taste for the vitreous but like the pottery of the Sandersons - "distorted by the intense heat in which [it] had been tried" (p.I40) - the hand disturbs Voss with the poignancy of its imperfection and suffering, and so he shatters it. Though this hand is supposed to bo of clay the syntax, suggesting some doubleness in the image of the dream, registers the real scars caused by Voss's preoccupation with the mineral. But deep down it is the hand of grain that he wants - the image recalls the bread which he has hungered after and rejected $(p p .30,39)$ - and so he snatches it up although in such a way as to pretend that it is not there:

It still had, most terribly, most poignantly, its semblance of flesh. So he shut it up in his bosom. He was afraid to look at it again.

The hand shut in his bosom accusingly recalls the actual scene of leave-taking in which a distracted Voss holds Iaura's extended hand without passing a word while he watches a woman brushed on the 
mouth by a horse's tail in the turmoil (p.I25). This woman, stuffed with horse-hair in the dream, stands in for the hollow-men of Sydney society against whom Laura and himself are united in complicity. The contrast between their closeness and vast separetion in space challenges the limits of memory. Words and names, the vanishing points of identity, are set against the unfinished stuff of experience ("raw jugs") until Laura, retiring bohind a mist of white muslin, turns back into the landscape out of which she came.

Voss's conflict is brought into the open by the letter from Laura in which she accepts his proposal on condition that they both struggle to subdue the arrogance that blinds then to their frailty. With the word "together" from Laura's parting injunction still resonating, Voss questions Palfreyman about his latest botarical acquisition, a lily with seeds "like testes, attached to the rather virginal flower", before he drifts into the most revealing of his dreams:

Then Voss began to float, and those words last received. But together. Written words take some time to thaw, but the rords of lilies were now flowing in full sumer water, whether it was the water or the leaves of water, and dark hairs of roots plastered on the mouth as water blen across. Now they were swimming so close they were joined together at the waist, and were the same flesh of lilies, their mouths, together, were drowning in the same love-stream. I do not wish this yet, or nie nie nie, niemals. Nein. You will, she said, if you will cut and examine the word. Together is filled with little cells. And cuts open with a knife. It is a see seed. But I do not. All buman obligations are painful, Mr Johann Ulrich, until they 
are learnt, variety by variety. But gold is painful, crushing, and cold on the forehead, while wholly desirable, because immaculate. Only resist the Christ-thorn. Tear out the black thing by the roots before it has taken hold. She was humbly grateful for it, however. In her kneeling position, she continued to bathe her hair in all flesh, whether of imperial lilies, or the black, putrefying, human kind. (pp.200-I)

This dream which vividly embodies Voss's desire for merging opens appropriately with a sequence of associations, the zeugma in the first sentence providing a lexical equivalent to the conjoined images ("words of lilies", "leaves of water") and apposed sensations (floating, thawing, flowing, swimming, drowning, blowing) that occupy Voss. Whereas in the previous dream Laura moves between stone and flesh, Voss now envisages his surrender in images that are half-way between the plant-like and fleshly. Joined at the waist Laura and he become one entity, the "same flesh" of a single flower. Through the visual presentation of the word "together" as a lily pod "filled with little colls", Voss who has formerly rejected "the voluptuous transports" of selflessness as feminine is now brought to recognize that merging and fertility are also the preserve of the male. The intimation is sufficiently disturbing to be instantly suppressed: he refuses to see - although, in the word "seed", the imperative continues to stare him in the face. So the dream procecds to resolve itself into an internal colloquy between the self dedicated to Laura and the old obdurate Voss, who attempts to fend Laura off by opposing, against her insistence on human obligation, mortality and sacrifice, his emblem of the golden crown. The old Voss signally fails, however, to maintain the upper hand and the 
dream stubbornly returns to the seed-pod which he has refused to see:

I do accept the terms. It was the sweat that prevented me from seeing them.

You are in no position to accept. It is the woman who un-makes men, to make saints.

Mutual. It is all mutual.

It was his tongue that would not come unstuck.

You have gained that point, the mouth was laughing.

Two zusammen should gain by numbers, but lose in fact. Numbers weaken.

The weaker is stronger, 0 Voooos.

Through a typographical device typical of James Joyce (compare Stephen's trailing ashplant in Ulysses - "my femiliar, after me, calling Steeeeeeeeeephen"), I2 given particular force here by the visual vehicle of the dream, Patrick White signals a decisive turning-point in the development of his hero. Voss who has savoured his own name as "a crystal in his mouth" ( $p .45$ ) now finds it turned into a seed-pod which serves as an emblem of strength through humility.

The image of the woman choked with horse-hair, though only latent in the dream - "dark hairs of roots plastered on the mouth" reasserts itself in protean forms that testify to Voss's continuing fear of entanglement. So he reflects bitterly on his dependence after delaying his departure from Jildra to await Laura's letter: "he could blame no one else for his own human weakness. He had delivered up his throat to the long, cold, glistening braids of her hair, and was truly strangling in them" ( $p$. I9I). It is Judd's paradoxical weakness that later provokes the essential formulation of his confliot: 
But when the fellow had gone away, he continued to suspect him of exeroising great power, though within human limits. For compassion, a feminine virtue, or even Erace, of some sensual origin, was undoubtedly human, and did limit will.

So the German was despising what he most desired: to peel the whale-bone off the lily stem and bruise the mouth of flesh ... He lay thinking of the wife from whose hands he would accept salvation, if he were intended to renounce the crown of fire for the ring of gentle gold. That was the perpetual question which grappled him as coldly as iron. $(p .227)$

Like the lion and the unicorn in D.H. Larrence's doctrinal essay who support the crown by each fighting for its possession, the values represented in Voss by the crown of fire and the ring of gold exist in a necessary tension. ${ }^{23}$ Though he initially enshrines an extreme, even pathological ideal of independence, Voss humbles himself sufficiently to realize his capacity for love, and accordingly epitomizes two passions that are at war in every individual - the itch for self-exaltation and the thirst for self-transcendence. In place of a stable resolution the novel offers the prospect only of perpetual struggle. Voss who will both kill and have, and kiss as well as kill (pp.285-6), is torn between the crown and the ring, and suspended between those symbolic presences that extend them, the "X-ray" Iike spirits of the dead and the warmly pigmented figures of the living, painted on the surfaces of the cave in which the explorers winter. A sheletal Voss shoots Gyp and callously scrutinizes Palfreyman on the way to his death while a being who "had taken human form, at least temporarily" ( $p .277$ ) submits to the ministrations of Judd and nurses Le fiesurier through his illness. The supernatural powers that preside over the action of the novel are at once creative 
and destructive. I4 God crucifies his son; and the Rainbow Serpent of Aboriginal mythology, manifest in the comet, descends through the heavens intent on swallowing what it has created (p.403). I5 The Great Snake comes to rest in the Southern Cross shortly before Voss is betrayed by Jackie; but both snake and cross symbolize the idea that suffering leads to renewal, a notif that recurs constantly throughout the novel in compressed images (such as "green lightning") or in extended episodes of symbolic action. "Dying is creation", Le Mesurier notes on the last leg of the journey (p.385), and his own delirious struggle with the Rainbow Serpent recails Jacob wrestling with the angel but, more crucially, the initiation of a medicine man:

Towards morning, Le Mesurier was wrestling with the great snake, his King, the divine powers of which were not disguised by the earth-colours of its scales. Friction of days had worn its fangs to a yellow-grey, but it could arch itself like a rainbow out of the mud of tribulation. At one point during his struggles, the sick man, or visionary, kissed the slime of the beast's mouth, and at once spat out a shower of diamonds. $(p p .299-300)$

Humility quickens his engagement in the stark realities of strife a far cry from Fichte's notion of dying into life - leaving him in possession of the crystalline. I6

Voss ends bis last letter to Laura with the words: "rhis is the true marriage, I know. We have wrestled with the gristle and the bones before daring to assume the flesh" (p.232). One of White's triumphs in Voss is to make us aware of relationships as acts of creation. The dreams in which Voss discovers the extent of his desire 
for Laura yield to a series of hallucinatory scenes and images through which he expands his conception of her. (Some sirteen such episodes are presented, in the last three of which Laura is given her own point of view.) A maxim of Nietzsche's applies with particular force:

What we do in dreams we also do when we are awake: we invent and fabricate the person with whom we associate and immediately forget we have done so. I7

Laura's physical absence isolates that unconscious work of the imagination that underlies all relationships, allowing us to observe the stages by which she assumes predominance in Voss's mind. Out of stone, at first a hooded figure, masked by her hair, by the collar of her coat, or with her back turned, Laura in the desert is slow to gain distinct human form. Her growth in Voss's mind is dependent on his relationships to the other members of the expedition, and controlled by the success of his struggle against pride. It is after Voss has allowed Judd to dress his head that Laura smiles, after nursing Le Mesurier that he first imagines Laura bearing a child. Finally, shortly before he is tended by her in the cave and they make a sacramental meal of lily plant together, he sees her - all fears of entanglement exorcised - "Quite naked. And beautiful", shorn of her hair. It is Mrs Bonner who is turned to stone by the "medusa-head" of her daughter (p.4IO). To Voss the leeches are merely the knives that incessantly stab the elliptical soul, visible to him, at last, in the desert (p.4I8). 
Voss, "truly humbled" at the end, dies in a chrysalis-like initiation hut (po.40I,4I4). Here, es throughout, White uses imagery connected with rites of passage to flesh out his persistent concern with sacrifice as a prelude to regeneration. ${ }^{8}$ It is Voss's after-Iife that the novel goes on to trace in the subtle but palpable impact of his legend on Sydney society; so that the idea of creative dying is ultimately written into the plot itself. I9 one of the most vivid realizations of this motif comes earlier in the text when Voss, moving to the mouth of his cave at dawn, witnesses a nature that seems in the throes of creation. The landscape that has previously mimed his awakened desire now responds to his feeling that "each morning is, like the creative act, the first". While the gradual emergence of form through the mist parallels his discovery of Laura, the strese laid on death and suffering again sounds the notion that frosh life is always rooted in anguish:

The rain was withdrawn temporarily into the great shapelessness, but a tingling of moisture suggested the presence of an earth that might absorb further punishment. First, an animal somewhere in the darkness was forced to part with its life. Then the grey was let loose to creep on subtle pads, from branch to branch, over rocks, slithering in native coils upon the surface of the wators. $(\mathrm{pp} \cdot 300-I)$

The scene owes a good deal, as the last detail shors, to the Aboriginal belief that the founding Gods (foremost among them the Great Snake) formed the world out of pre-eristent but amorphous matter - the "protoplast" or "gelatinous, half-created" mass mentioned later in the sane passage. 20 At a time when the 
anthropologist Mircea Eliade was devoloping his view that the initiation rites of a culture recapitulate its cosmogony, white extends a psychological emblem of continuous death and rebirth into a myth of creation, a myth which serves to underline the always unfinished state of nature - a myth more consistent, in this respect, with evolution than is Genesis. $2 I$

Although largely overlooked by commentators on Voss, White's annexations of indigenous lore are as many-sided as they are crucial. In addition to the Rainbow serpent and related ritual there is the notion of dual fatherhood that underlies the parenthood of Rose Portion's daughter, Mercy. White goes out of his way, also, to associate the celebrated "X-ray" style of rock-painting with his own technique of presenting the unseen at face value (p.299), and Voss's apparent clairvoyance begs comparison, too, with Aboriginal belief in a "dream time". so extensive an assimilation is without precedent. Never before in fiction had an explorer been transparent to the culture of the land through which he travelled. 
The Sacramental Wild:

A Fringe of Leaves

"There was somebody murdered here in the beginning": when white, at the climax of The Eye of the Storm (I973), has the Warming children weave a private myth of creation round the story of Eliza Fraser, a famous castaway off the queensland coast in I836, he anticipates his own fictional working of this material in his next novel, A Fringe of Leaves (I976). I The island on which white's heroine comes ashore, holds in its sunlit stretches the promise of "paradise itself", but it is here that Ellen Roxburgh first confronts the darkly perplexed sources of passion, a theme articulated later in the remark she makes to her rescuer Jack Chance - "many have murdered those they love"; and it is here, too, after her capture by a tribe, that she exults in a meal of human flesh. ${ }^{2}$ In the earlier novel, the same island witnesses the still centre of the typhoon during which the rapacious Mrs Hunter, after seducing away her daughter's would-be lover, finds peace in the clear-eyed recognition of her predatory nature. That the object of the rivalry between the two women is a marine biologist whose special interest, the sea-bed, is repeatedly linked with the unfathomed mind (while his testicles more plainly recall cuttlefish) hints that it is evolution that lies at the heart of nature's turbulent mandala. ${ }^{3}$ Aetiology, however, plays little part in A Fringe of Leaves which from its "prologue" to its last sentence goes straight to the question of what human nature is. But though White pursues the limits of "people's frightfulness" much further here than in Voss, where the theme of betrayal is only partly developed, his affirmations are seldom more firmly based than they are in this moving and astringent piece. 4 
"GOD IS LOVE": the legend dribbled in ochre across the whitewashed wall of the unconsecrated chapel built by Ellen's fellow survivor, Pilcher, is as bald as it is simple. What gives instant sense to it is Ellen's perception of the way the humble building generously accommodates the natural - the sky, sun, nesting birds and, with them, the thoughts that pass through her head. There she can accordingly relive the "betrayal of her earthly loves", concentrating experience that ranges from tenderness to lust and reaches a consummation in the "sensual joy" of her relationship with the escaped convict, Jack Chance (pp.390, 302).

Pilcher's chapel closely corresponds to that ideal place of worship sketched, after a visit to Lincoln cathedral, by Will Brangwen in The Rainbow (I9I5) - "a temple ... ruined and mixed up with the winds and the sky and the herbs". 5 Lawrence and White share a distrust of systems and habits of mind that shut out, and they both celebrate freedom by enshrining the wild. It is no surprise then to find a suitable frame for White's treatment of the Australian landscape in Lawrence's fiercely polemical novel Kangaroo (I923) which, in pitting the dark gods against received Christian belief, conscripts even the terrain. While the glib creed of brotherly love, upheld by Kangaroo, is associated with the soft pastoral of the coastal fringe, his sceptical disciple Jaz looks to the interior (his eyes are of the same grey as the bush) and Somers, the author's spokesman, not only welcomes the "uncreatedness" of the new country but repeatedly pictures human nature as volcanic since energy issues, he explains, from a source beyond the will.6 In a chapter headed 
"Volcanic Evidence" Lawrence translates this idea - which includes the sense that "destruction is part of creation" - into the bedrock of the continent, identifying Fraser island, curiously enough, as the centre of a hidden fault that will yet rain fire on the land. " "Some men", Somers observes of himself, "have to be bombs, to explode and make breaches in the walls that shut life in". 8 What underlies his half-entertained revolutionary schemes is a psychological conviction that integrity can only be won at the risk of including forces that threaten secure existence.

White's primitivism is more muted, his finely grained realism a far cry from the tendentious mode of Lawrence's essay-novel, but there is, all the same, much common ground. Al though Ellen's attitudes to civility and the wilderness are so delicately balanced that she is brought, by turns, to the brink of escaping on her own from each, her growth is nevertheless charted against an ever outward movement into nature. She begins, in terms of the novel's action, as Mrs Austin Roxburgh cabined with her invalid husband aboard the Bristol Maid on their return to England from Van Diemen's Land, and the vcyage, before it ends in shipwreck, unfolds her past in a series of layered settings. While still at Sydney, waiting for the boat to sail, she escapes from the "narrow saloon" to glimpse something of the "forbidding landscape" that lies beyond the harbour town, and immediately conjures up two other contrastive landscapes - the recent lush fields of Dulcet, the estate belonging to her brother-in-law Garnet whom the Roxburghs have travelled across the world to see, and the relatively pinched farm of her Cornish 
childhood (pp.32-3). As the stages of her history surface successively over the ocean, we learn of her painful transformation from country girl to Cheltenham lady after her marriage (shortly following her father's death) to Austin, a paying convalescent. For the bejewelled and gloved Mrs Roxburgh the refinements of Birdlip House with its polished surfaces, caged linnets and netted pears entail some distance from reality, a distance realized earlier in the tension between Austin's pastoral expectations of a Cornish farm and the pig pegged down for slaughter across which he stumbles. And while it is true that Ellen retains a vision broader than her social roles would seem to permit, and that her love of Austin is restricted, chiefly, by his intolerance of passion, a deeply repressed urge in her for further experience becomes apparent on her first excursion into the wild.

About to drift asleep in an indigenous forest on the mountainside of Garnet's farm, she feels herself "only remotely related to Ellen Roxburgh, or even Ellen Gluyas", and reflects, "she was probably closer to the being her glass could not reveal, nor her powers of perception grasp" ( .92$)$. In the compression of her dream Garnet - his oresence signalled by ripe plums - coalesces with the figure of her chosen lover who in a visual idiom revived from her adolescent fantasy, sails into Tintagel cove. Although the dream is instantly forgotten, it is not long before an un-Roxburghian self stage-manages her seduction by Garnet in exactly the same part of the wood. Her feelings towards her brother-in-law which have up to this point been mixed - revulsion masking the depth of her desire - now rapidly shift to self-disgust 
as her loyalty to Austin combines with growing insight into the real brutality that underlies Garnet's sensual charm. Both her awakened sensuality and guilt leave a lasting impression. She dreams that she has been "GARNurd"; or, on another occasion, watches a stake pass through Austin's heart, transferring to him the fate that Garnet has spitefully arranged for her mare ( $p p .182$, I57-8). Paradoxical though it may seem, Ellen's first encounter with the wilderness, because it opens an anguished consciousness of her capacity for betrayal, contributes as much to her moral growth as to her gain in experience. Ellen, in exacting knowledge of her flawed nature, remains true to the maxim quoted among the epigraphs - "If there is some true good in a man, it can only be unknown to himself". Simone Weil's precept reaches, too, into the second and more crucial stage of her development which is once again initiated, after her meeting on the mainland with Jack Chance, by "a passion discovered only in a country of thorns, whips, murderers, thieves, shipwreck, and adulteresses" (pp.3II-I2).

That the narrator retails the experiences of Dulcet while Ellen lies huddled in the empty form left by Austin in the lower bunk of their cabin gently points to the psychological nature of the frontiers which face Mrs Roxburgh (pp.70,78). A "theory of prevention by suffocation" $(p .66)$ is her unwanted legacy from her mother-in-law and she often has cause to regret Austin's attempts to protect her in return. Throughout the novel we are alerted to the inner barriers dictated not only by the pressures of intimacy but by social convention and, ultimately, by class. In this respect Ellen's progress closely 
resembles that undergone in Voss by Laura Trevelyan, for whom exploration takes the form of befriending her emancipist servant Rose Portion and adopting her child. Ellen goes further, however, in her violation of social taboo. Indeed, where Voss is impelled towards growth by deeds which patently fall under the heading of Christian service, Ellen's path of deliverance leads through the underworld. A ready sympathy disables the middle-class stereotypes which threaten to enclose her, and it is precisely to the development of this gift that she owes her almost visionary, final stature. When she recalls, after her return, Garnet's sneering dismissal of "these miscreants, the sweepings of the London streets", she realizes that "unrestricted association with the convict made her his accomplice" and that, in society's eyes, she herself stands effectively condemned not only of cannibalism but of murder ( $p .3 I 6)$. But from the first, her Cornish roots quicken insight into the arbitrariness of social definition. On learning, for example, that the housemaid has suffered transportation for the same offence that has caused her master to emigrate, she asks herself how much of the miscreant there is in Garnet; and is swift to add, "Or in myself?", so calling attention to a kinship, felt the moment she sets eyes on a convict gang, that goes back to the hardship of her childhood (pp. 89,84). In retrospect it becomes clear, as I hope to show, that a structure of social relations forms the core of Ellen's discoveries in the wild. Landscape, which represents for Voss both the driving force and minutely rendered record of an inward journey, serves in A Fringe of Leaves rather as a series of pointers. 
Although the intense and varied processes of bonding that increasingly absorb the text after the wreck of the Bristol Maid develop the novel's concern with sympathy, the word itself proves too broad for analysis, and a distinction drawn by Jung between two ways of approaching the new turns out to be a help. While "assimilation", in his terms, involves approximating fresh things to old experience, "identification" amounts to its opposite - the formation of a "secondary character" to accommodate the fresh. IO Ellen then assimilates Holly when she sees that "the girl's fate might have been her own, that of a scullery-maid becoming a drudge-wife" (p.9I), and her aroused sense of affinity is sealed by the gift of the garnet ear-rings that make her look "trumpery" though they point also to a further tie, their sharing of Garnet, which she is less keen to acknowledge. Further examples of assimilation occur when she repeatedly brings Captain Purdew into focus as an image of her father, or slots oswald into the role of her lost son. These approaches by "proxy", as White calls them, crop up throughout and play a part in almost all the relationships, but most strikingly perhaps in Austin's life with Ellen, who happily unites those "opposite poles of his existence", his mother and his brother (pp.3I0, I49).

The opening chapter introduces us to a quite different sort of social participation in the brief account given of Austin's childhood illness:

"And the strange part was, it seemed to draw him closer to his very unlikely brother. As though he hoped to borrow some of Garnet's health and strength." 
Mr Merrivale's remark is later filled out by Austin's dream of Garnet as a type of the full-blooded person he would have had himself be (his brother stands aflame on the far side of the nursery fender after a bath), and by the statement that their forced separation affected him "as though he had suffered the amputation of a limb" (pp.I48-9). This source of energy remains untapped, however, for once the brothers are reunited Austin withdraws, making no more than the odd gesture towards their shared past. Only after shipwreck and privation have stripped him of his props and accustomed roles does he begin to grapple with those "substantial shadows" which his readings of Virgil have grimly underlined $(p p .34,68)$. II And only on the longboat does he taste the first fruit of his belated growth, an ecstatic sense of union with his wifes

Plastered together in their drenched condition, they were truly 'one flesh', an expression he had been inclined to reject as in bad taste, until the senseless caprices of nature invested it with a reality which had become his mainstay. (p.I98)

His joy on this occasion is preceded by a further image of Garnet freshly bathed by the nurse, and a related memory fuels the episode that follows - an episode crucial not only to his development but to the novel's symbolic scheme. Applying a remedy once applied to Garnet by Nurse Hayes, Austin tends to a boil on the neck of the dying second mate. The sense of fellowship released by this act leads Austin to dream, shortly after Spurgeon's death, of a rite which begins as a displaced version of the Christian sacrament:

Yet his thoughts were only cut to a traditional pattern, as Captain Purdew must have recognized, who now came stepping between the heads of the sleepers, to bend and whisper, This is the body of 
Spurgeon which I have reserved for thee, take eat, and give thanks for a boil which was spiritual matter ... Austin Roxburgh was not only ravenous for the living flesh, but found himself anxiously licking the corners of his mouth to prevent any overflow of precious blood.

Though the dream provides its own gory transubstantiation of the Host, the usual implications of Eucharist apply, even if their textual enactment, thus far, is largely notional. The sacrament raises, in the first place, the idea of identification - of an enlargement undergone by the self in taking on the qualities of another being, in this case Garnet's distant proxy. Secondly, it demonstrates a common bond among the celebrants; a sense introduced by the pannikin of rum which, sent round the longboat at the sight of land, recalls a chalice (p.203).

Austin's dream provides a prelude to that pregnant phase of existence that Ellen enters after her capture by an iborigine tribe. The moment of her stripping, and separation from the other survivors, comes at the end of a series of losses so severe as to leave her clinging to the last outward sign of public identity, the ring given her by Austin. So complete is her bereavement Austin's death following her miscarriage and the drowning of Oswald - that she is withheld, for some time, from the people who make up a fresh life about her. The tribal society which the novel portrays here is free, for once, of that symbolic freight which commonly distinguishes the role of primitives in texts dealing with exploration. By articulating the features of a distinct culture White dispels the concept of race, and with it 
goes the myth of a Naturvolk. Life among the Aborigines is shown to consist in an intricate balance between ritual and need, instinct and code; and Ellen in learning the ways of her community is alternately reminded of her Cornish background and of her time at Cheltenham. Such approaches fall into the category of assimilation, but they take Ellen only part of the distance towards feeling at home in her new context, and it is telling that the sick baby girl whom she is obliged to suckle fails conspicuously to replace the children she has lost. It is rather her shocked understanding of the child's state that sparks the first intimations of kinship between her and the group. In a vibrant scene, White shows an old - possibly infirm - medicine man extracting, first, a crystal from the baby's mouth and then, after the child's death, doing his utmost to persuade the crowd that Ellen is to blame. The family seem almost convinced, but all is changed when, giving vent to emotions she has long checked back, Ellen bursts into tears: "For the first time since the meeting on the beach", the narrator comments, "the captive and her masters, especially the women, were united in a common humanity" (p.26I). In a seminal study of cross-cultural perception Edward Said has pertinently questioned whether "ethnic origins and religion are the best, or at least the most useful, basic, and clear, definitions of human experience". I2 White supplies a valuable corrective to ethnographic determinism when he focusses on the gap between daily living and the official creeds. 
tribe is a bizarre ritual that follows on a number of her encounters with a beautiful girl whom she first sees diving for water-lilies. The sight is memorable,for it provides a brilliant relief from the stale task of collecting food, and Ellen is quick to recognize the lily-diver when she finds herself drawn later into a compromising tangle by the girl's powerful lover. In making an advance to Ellen, this man, already flanked by two mistresses, puts her in a position towards the young girl similar to that she has entertained towards Holly in her liaison with Garnet, or will occupy towards the Irish girl in her relationship with Jack Chance. She sees the lily-gatherer killed in a fight with her rival, and the next day stumbles on, and devours, a cooked thigh-bone which is all that remains of the girl after a secretiy held feast. Although bewildered by the violence of her act, Ellen instantly recognizes her fulfilment of "some darker need of the hungry spirit" (pp.272-4). She realizes, in sum, that the rite holds a significance for her that goes beyond the fact of her having broken a taboo of her own cul ture.

Each of the sacramental principles suggested earlier in the text now comes into play. In the first place, a sense of unanimity steals over Ellen who begins to regard herself as a member of the tribe. At the grand corroboree she accordingly joins the swaying figures in the dance until all are "melted together"; and her new role soon proves sufficiently secure to allow her to pass judgement on the life she led at Cheltenham (pp.283,286). She 
keeps her old identity to the extent, it is true, of continuing to look out for means of escape, but the contrary urge to belong is already clear from her response to the children she mothers on her way to the festival - "she could have eaten them" (p.276). White's treatment of the other principle is more extensive.

A wish to acquire the qualities of the creature consumed underlies, it seems, not only the Eucharist but many cannibal rites. The point is made by Janet Lewis in her novel The Invasion (I932), a vivid account of cultural assimilation on the early American frontier:

On another evening they talked of the Christian mystery. "I understand you," said the Indian, "when you say that your god becomes bread and that you eat of the bread, not to eat your god but his godliness. We too when we eat of the heart of a brave man eat not the heart but the courage. There is no Ojibway who would taste of the blood of a coward."I3

White bases the cannibal feast in A Fringe of Leaves on a mortuary custom reported among the Aborigines - particularly in the South Queensland region, which fits the setting. I4 "Acquisition of the dead person's qualities" forms the underlying tenet of this rite; ${ }^{5}$ and round it White constructs an elaborate symbolic fable. I6 one afternoon at the height of her relationship with Jack Chance, Ellen busies herself in his absence by practising a skill she has learnt from her time with the tribe, so that on his return with a slaughtered emu, a bird so human that it immediately recalls ber feast of flesh, he is met by a woman in the image of the 
lily-gatherer - "hair plastered, shoulders gleaming and rustling with water" - and greets Ellen as his lubra (pp.3I6-I7). In the sheet of lilies they tumble and embrace, but the scene is important not only for showing their "sensual joy" (in the lily imagery White carries over a motif of sexual merging from Voss) but for illustrating Ellen's capacity for extending her repertoire of selves. Ellen who shifts by turns between Gluyas and Roxburgh, speaker of dialect and standard English, figurine and wench, slave and demi-goddess, lubra and nun, prude and miscreant, who sees herself in the shoes of Holly, Pilcher and Garnet's dead wife; and who later sctually takes herself to be both Jack and his mistress Mab, proves the most protean of heroines. Nothing could characterize her better than what amounts to a myth of continuous incarnation.

But Ellen's sacrament, which she herself regards as unredeemably pagan, reveals other, and darker, depths. It stands as far from the eucharist imagery of Voss with its attendant celebrations of "togetherness" as it does from Austin's selfless care of Spurgeon, more closely resembling, indeed, that black mass which Brendan Boyle envisages in the outback. I7 The severest of White's concerns in Voss, the paradox of growth-in-destruction is taken up with renewed energy in A Fringe of Leaves, where it is imaged by the very nature of Ellen's rite which distils life from the dead. Over Ellen's meeting with Chance there presides the Rainbow Serpent embodied by the dancers at the corroboree, and it prefigures a pattern of falling and rising fortune in which the lovers will lose as they have gained. It is at the moment that Ellen, already 
absorbed in the dance, pictures herself consuming the burnt remains of her husband, that the mysterious "Ulappi" detaches himself from the tail of the serpent to enter her life (pp.283-4). The idea of loss as a prerequisite to creation finds an emblem later in the torn lilies at the place of their passionate encounter,

it was sad they should destroy such a sheet of lilies, but so

it must be if they were to become re-united $(p .317)$ and in a variety of guises this notion is to haunt each emotional climex of the novel's most potent relationship.

The cannibal imagery that White applies to erotic love takes its place in a series of comparisons relating sex to eating; and the flamboyant nature of many of these - Ellen locked in Garnet's embrace sees herself as a "partially disabled, obscene bird, on whose breast he was feeding" (p.II6) - makes the plain, almost idiomatic statement of her feeling for Jack start into relief:

She would have swallowed him had she been capable of it. (p.299) White engineers a context in which tris remark, along with the earlier aside - "she could have eaten them", tempts us to question just how figurative the everyday endearment is. While the lovers feast on a couple of pigeons (birds foreshadow human destinies throughout) Jack, going back to his days as a bird-catcher, dwells on the force of necessity, and brings home to Ellen the fecklessness of ordinary drives:

'Most birds and animals - plants too - is neglected - once the whim to own 'em dies in the owner.'

'Then why did you carry on, Jack, at what amounts to an 
immoral trade?'

'If we considered only what's moral we'd go 'ungry, wouldn't we? an' curl up an' die. There's too much thinkin' - an' not enough. Would men go with women, or women with men, if they started thinkin' of the trouble - the deceit and treachery they might run into?'

That the sources of human energy are tainted appears both in Ellen's fruitful disloyalty to Austin and in the urge for preservation that prompts her, at length, to sacrifice Chance. But even before the plot unfolds its appalling symmetries of betrayal, white alerts us bit by bit to the callous conduct that triumphs, as if irresistibly, over the most tenderly nurtured intentions. Here casual words and gestures play their part. We see Ellen blasting Oswald's trust when she accuses him of "ferreting" out her thoughts (a ferret being the subject of their first confidence); and Austin shows himself ready to mock his wife in order to win the approval of the crew (pp.I97, 203). The lie to selfless merging is given, again, by a comic succession of buffetings and tramplings - accidental, unconscious, or even intended - that attach impartially to all love relations in turn. It is while demonstrating her sympathy and altruism, for example, that Ellen knocks Austin with an outflung arm, or, on a later occasion, rams Jack with her knee (pp.2I8, 3I9); and, though deeply put out to find herself standing on the hand of her husband's corpse, she later quite deliberately brings down a foot into her rescuer's face in order to prevent him climbing up to her in the tree $(p p .244,318,319)$

In so far as Ellen discovers a source of grace in the wilderness, 
it is through her pained but ever increasing recognition of human ruthlessness, and she is faced with a crowning disclosure when Jack, shortly before they reach the outskirts of settlement, confesses to the murder of his mistress Mab. In this act Ellen feels herself to be doubly implicated - like Mab she has been unfaithful, and her violence to Austin, whom she has imaged with a stake through his heart, aligns her also with Jack. That Jack should kill Mab's other man, the sword-swallower, with his own weapon, calls up the well-known lines from the Ballad of Reading Gaol, echoed in Ellen's self-inculpating response, "many have murdered those they love" (p.324):

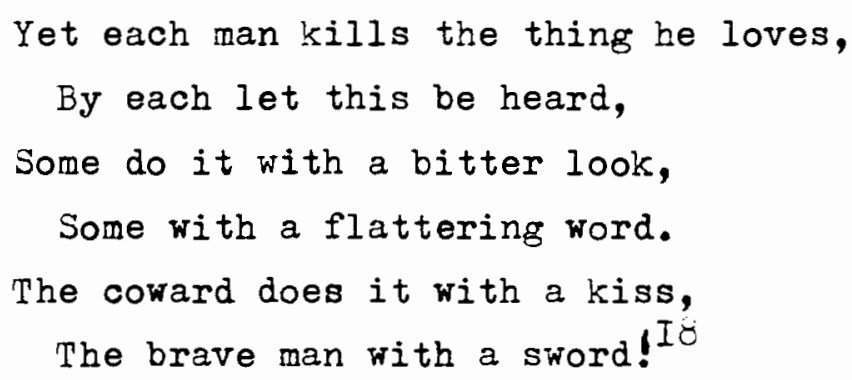

As a foil to Jack's passionate brutality White includes the account of Pilcher's wife who dies of a loveless marriage, and makes it clear that the accident suffered by the wealthy Mrs (Dormer) Roxburgh was carefully premeditated by Garnet who remains unconvicted (pp.378,90,IOI). Though only notional, Ellen's involvement in Jack's crime is further intensified by the guilt she feels over the drowning of her beloved oswald, and even over Austin's killing for she cannot forget that in drawing the spear from his neck she supplied the immediate cause of death (pp.218,240). The imaginative resources which she brings to bear on the events following Mab's 
murder are profound, and her almost hallucinatory reconstructions of Jack's refuge in the London sewers and his return to the cottage at Putney full of dead birds, represent a correspondingly rich expression of her power to empathize (pp.325-7). Nor is her exploration of these events limited to her lover's point of view. Having already taken on the experience of Mab to the extent of weeping at her supposed separation from Jack, and with a complicity strengthened, too, by their common adultery, Ellen now casts a nervous glance at Jack's axe. The passages in which she recreates the unseen (rendered by White in the X-ray style of Voss) prepare the reader for the confused identity which she reveals in her delirium on reaching the colony. "I am Mab", she tells Mrs Oakes, but she is as much Jack for she pleads to be spared flogging at the triangle $(p .337)$. The answer to the question she frames at Dulcet before her journey has really begun - how much is she a miscreant - comes partly in her formal statement to the Commandant at the settlement, "most of us are guilty of brutal acts, if not actual murder", less soberly in her retrospective agony over her desertion of the man she loves: "Even if Jack is not - destroyed if he simply lies down and dies - I must give myself up as his murderess" (pp.367, 344).

We see, nonetheless, that whenever Ellen believes her survival is at stake - the tree-climbing incident provides a good example compassion counts for little or nothing. Chief, indeed, among many paradores focussed by the cannibalism of the novel's central rite is the implication that Ellen's sympathies and betrayals are not 
easily disentangled. It is, in truth, a relentless urge for experience ("a matter of choice", as Miss Scrimshaw notes, p.23) that leads to her wide-ranging insight into the plight of others. The "continued immanence" of her victims and loves (p.255) represents the more positive aspect of her tragic life, as it does of her dark sacrament; and this aspect appears in the breadth and readiness of her emotional response to society on her return to the penal settlement of Moreton Bay. Here, when the long expected convict gang comes into view, she finds herself without any of the defensive screens available to her earlier at Van Diemen's Land: with the familiarly roughened men she is instantly "united in one terrible spasm", a union the more cruel for being wholly one-sided ( $p .370)$. Still more poignant, however, is her meeting with the Irish convict responsible for Jack's getaway - a woman who has entered her fantasy as deeply as Mab (pp.3IO-I2) - for the rapport established between them only highlights the barrier that keeps them apart (pp.372-3). Ellen has cause to brood over the effects of a divided society, each side of which she has come to contain in the course of her wandering:

It saddened her to think she might never become acceptable to either of the two incompatible worlds even as they might never accept to merge.

The priest who drops in and blithely continues his prayer oblivious to the rending cries of a man at the triangle, typifies the "moral classes" referred to by Spurgeon ( $p .2 I O)$, from which she has made ber escape. Ellen's journey translates at last into a penetration of the community about her, and her progress is mapped in these 
terms by a narrator who applies the metaphor of space. Conversing with the crew aboard the Bristol Maid Ellen has yet "to bridge the gulf separating life from their own lives"; but when she approaches the party of female convicts in search of the Irish girl it is to discover that she has in effect eaten through "the distance separating her from the women" (pp.I54,372).

The penal colony that stands in for the larger society at the close of A Fringe of Leaves is in many ways uglier than anything Ellen experiences in the wild. Very much as Garnet's murder of his wife surpasses in its cold calculation the evil of Jack's impulsive violence, the exacted labour and controlled exploitation of Moreton Bay prove more deeply invasive than Ellen's informal enslavement by the tribe. And although white varies the stress in his final chapter we see Ellen drawing comfort from frequent kindness, and specially from the candour of the Lovells' children - he sets out to warn his readers of the way in which a society can conceal the blood-thirstiness which it has institutionalized. His view comes close, here, to that boldly advanced by Nietzsche in Beyond Good and Evil:

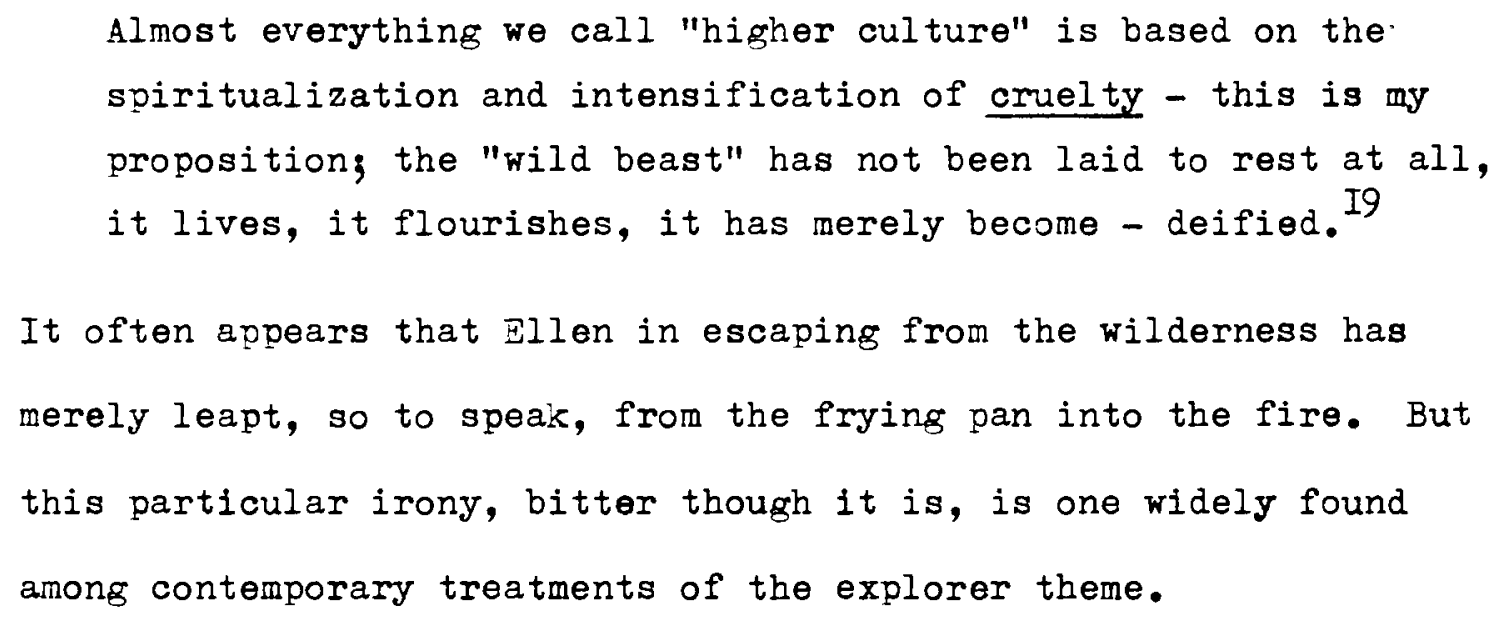


A vivid instance is supplied by the ending of Golding's Lord of the flies (I954) where there suddenly opens up, beyond the catastrophic present, a vista of cruelty on a greatly extended, if more distinct scale: a warship waits for the fleeing boys, and the uniform of its Captain chimes disturbingly with the masks devised by Jack for his warmongering party. By way of corollary, flight from society is rewarded in An Imaginary Life (I978) - David Malouf's brilliant fusion of atavism and metamorphosis - for here Ovid, accompanied by an adopted wild boy, escapes from the community where he has passed his exile, to push ever further into the wilderness until he meets with an ecstatic death. In Dusklands (I974) J.M. Coetzee achieves a comparable emphasis by reversing the chiaroscuro traditional to much of the genre and challenging, with fine poise, its implication. An explorer accordingly demonstrates his "true savagery" when he turns his back on the broad daylight of the interior, descends into familiar twilit terrain, and finally celebrates his home-coming with a bout of slaughter that he blames on Bushmen; the only dark streak in the desert is the shadow cast by his presence. 20 André Brink in An Instant in the Wind (I976), a quite independent working of the Fraser-Bracefell legend adapted to the Cape Colony of the eighteenth century, takes the contrast between the ethos of settlement and wilderness even further. His heroine, the wife of an explorer widowed far beyond the frontier, is initiated into a paradise by Adam Mantoor, the escaped slave who rescues her. The rapid stages by which the values of a wilfully repressive society erode their relationship, after their return to the Colony, are compellingly observed until, advancing on her 
original, the rescued widow has her lover condemned to death. 2 I While making use of a documentary apparatus, both Coetzee and Brink create historical fictions which embody an image of the present in the past. 22

Though less glowing than Adam's paradise, Ellen's experience of the wilderness has no less value, for what she discovers there provides, again, a yardstick for the appraisal of society. Indeed, the metaphors of imprisonment which White freely draws from the penal settlement point not only at particular, restrictive codes but also as when we are told that Ellen "had been sentenced, a lifer from birth" (p.359) - at the condition of civility itself. So, too, the sudden cry of pain that breaks from Ellen once aboard the boat that will bear her back to the thoroughfares of urban life, expresses the passion she has lost in rejecting Chance but voices also the unspoken grief felt by civilization's every discontent. While the shades of the prison-house begin to close round White's Wordsworthian woman, who has learnt from her truancy in the wild just how much she "desired to love without reserve" (p.302), it becomes clear, however, that her story is meant as a moral viaticum as much as an antidote to repression. ${ }^{23}$ In acquiring the self-knowledge that she recognizes as "a source of embarrassment, even danger" in her society (p.34I), in despairing at times of finding any good in herself, Ellen grows quick at least to penetrate evil. Her insight into the difference between "instinctive brutality" and the malevolence of a "calculating mind" increasingly irradiates her response, informing finally her determined fulfilment of the promise to procure Jack's pardon as well as the words on justice 
that she passes to the Commandant ( $p$. I38, 342). Her development illustrates, overall, a remark made by Simone Weil that supplements the saying quoted by White as an epigraph: "sin is nothing else but the failure to recognize human misery". 24

Weil writes elsewhere of the "monstrous discrepancy between man's body, man's mind and the things which at the present time constitute the elements of human existence". 25 An appeal to human nature underwites every bid to show that society is not the measure of man it is difficult to see how any comparative judgement of social life could be possible without it - and ever since Defoe novelists have turned to explorers and castaways to found such appeals on the presentation of experience in the wild. That these pictures are all to some extent a reflection of the contexts in which they arose hardly saps the impulse to search for extrinsic standards on distant ground. And for this reason the explorer theme is likely to persist in fiction, even if predominantly in historical guise. The hero of Faulkner's novella, The Bear (I942), who returns annually to a forest that shrinks until it eventually disappears, speaks for the genre when he tells himself that he can "never lose it". What he feels, after all, is "the old life of the heart, as pristine as ever, as on the first day". 26 


\section{Notes and References}

\section{The Explorer, and Views of Creation}

I. From "The Letter on his Third Voyage, October I498", in Select Documents Illustrating the Four Voyages of Columbus, translated and edited by Cecil Jane (London, I933), I, I6-18.

2. Although he would not have read Mandeville in English the Travels were available to Columbus in any one of "several Italian, French, or Latin editions, or in manuscript in Spanish", as Josephine Benrett observes in The Rediscovery of Sir John Mandeville (New York, I954), p.235.M.C. Seypour in the preface to his edition of the Travels (Oxford, I967, xx) remarks: "When the Santa Cruz sighted land on I2 October I492, a copy of Mandeville's Travels lay beside Marco Polo's book in the admiral's day-cabin". Frequent and often detailed references throughout Columbus's writings leave no doubt as to the truth of this claim.

3. Mandeville's Travels, edited by M.C. Seymour (Oxford, I967), pp.22I-2.

4. Select Documents, I, 36 .

5. See J.S. Collis, Christopher Columbus (London, I976), pp.32-4; and for a discussion of his Messianic intuitions Cecil Jari' $\mathrm{Z}$ introduction to Select Documents, I, Iii.

6. Select Documents, ㅍ, 26 .

7. In Aids to Reflection (I825): see OED under "Projective.5". The two inset examples are also from the $\underline{O D D}$. Coleridge's concern with projection is central to "Dejection: An Cde", and to "Constancy to an Ideal Object"; but important also in most of the earlier "conversation poems".

8. A la recherche du temps perdu, translated by C.K. Scott Moncrierf, Swann's Way: Part One (London, I94I), pp.9-II. For an earlier (and wonderfully controlled) use of the optical 
metaphor see Pope's Epistle to Cobham, lines 23-8:

the diff'rence is as great between

The optics seeing, as the objects seen.

All Manners take a tincture from our own,

Or come discolour'd thro' our Passions shown.

Or Fancy's beam enlarges, multiplies,

Contracts, inverts, and gives ten thousand dyes.

In the one-volume edition of the Twickenham text, edited by John Butt (London, I963), p.550.

9. Select Documents, I, 4-6.

IO. Paradise Lost, IV, lines 600-4.

II. On the mappa-mundi and its developments see Erwin Raisz, Mapping the World (London, I956), pp.35-7; and J.H. Parry, The Age of Reconnaissance (Berkeley, I98I), pp.IO7-9.

I2. From "Arthur Barlowe's Narrative of the I584 Voyage" in Virginian Voyages from Hakluyt, edited by David and Alison Quinn (London, I97 3), p. 8 .

I3. "A Briefe Relation of the New Founde Land" (I583) in Richard Hakluyt's The Principall Navigations ... of the English Nation, first published in I589 and enlarged I598-I600 (Glasgow, I903-5), VIII, 60.

I4. For example, John Smith who knew the American coastline from Florida to Maine remarked, "Could I haue but means to transport a Colony, I would rather liue here than any where". Works, I608-3I, edited by Edward Arber (London, I895), II, 708.

15. Collected in Perry Miller's anthology, The American Puritans (New York, I956), p.I7.

I6. In an open letter addressed by Hakluyt to Sir Walter Raleigh. Principall Navigations, VIII, 443.

I7. The Tempest, II.1.45-53. See the New Arden text, edited by Frank Kermode (London, I958), p.45. For a fuller account of this theme in 
The Tempest see my article "The Man in the Island's Shakespeare's concern with projection in The Tempest", Theoria, LXI (I9 83), pp. 23-36.

I8. "An Outpost of Progress" in Tales of Unrest, Dent's Uniform Edition (London, I923-8), p.92.

I9. See J.G. Frazer, "Some Primitive Theories of the Origin of Man ", in A.C. Seward, Darwin and Modern Science (Cambridge, I909), p.I59; and I. Petrov, Report on the Population, Industries, and Resources of Alaska (Washington, I884).

20. R.R. Cawley cites eleven instances, all of them independent of mine. The Voyagers and Elizabethan Drama (Boston, I938), pp.290-I.

2I. From "The True and Last Discouerie of Florida made by Captain John Ribault in the yeere I562" in Divers Voyages Touching the Discovery of America (I582), translated and edited by Richard Hakluyt. Edited by J.H. Jones (New York, I850, reprinted[I97 I), pp.IOI-2. 22. The Essayes of Montaigne, translated by John Florio (London, IE9 I), p.94.

23. Genesis $2: I 5$

24. The Metamorphoses of Ovid, translated by Mary M. Innes (Harmondsworth, I955), pp.3I-2.

25. "To the Virginian Voyage". Poems of Michael Drayton, edited by John Buxton (London, I953), I, I24.

26. The Ternpest, II.i.I47-53.

27. Sir Henry Morton Stanley, In Darkest Africe (London, I890), p.35I.

28. In Darkest Africa, pp.349-50.

29. In Darkest Africa, 0.354

30. In Darikest Africa, pp.354-5.

3I. Genesis I:28

32. I Samuel I5:22. The context would certainly have been known to Stanley who read the Bible twice over on this expedition. See In Darkest Africa, p.I8I. 
33. In Darkest Africa, p.355.

34. Robert I. Rotberg comments on Stanley's lack of patience with Living:tone's lenience towards stragelers, and goes on to quote from Sianley: "My blood is up... It is a murderous world, and I have begun to hate the filthy, vulturous shoals who inhabit it." Africa and its Explorers (Cambridge, Mass., I970), p.243.

35. See the introduction to Divers Voyages br J.H. Jones, ciii-civ.

36. See David B. Davis, The Problem of Slavery in Festern Culture (Ne- York, I966), p.8.

37. "The discoverie of Guiana" in Haxluyt's Principall Navigations, $\mathrm{X}, 428$.

38. The Exploration Diaries of H.M. Stanley, edited by Richard Stanley and Alan Neame (London, I96́I), p.IO5.

39. Herodotus, The Histories, translated by Aubrey de Selincourt (London, I954), p.2I9.

40. Mandeville's Travels, p.228.

4I. Quoted by George Seaver in Edward Hilson of the Antarctic (London, I9 33), P.II9.

42. William Burchell, Travels in the Interior of Southern Africa (London, I822-4, reprinted I953), I, 5 .

43. François Le Vaillant, Travels into the Interior Parts of Africa, I780-5, translated from the French, second edition (London, I796), I, I45.

44. Travels, I, I32-3.

45. Travels, I, I27.

46. Travels, II, I3.

47. Travels, II, I4. My italies.

48. Travels, II, I25.

49. Humboldt comments on Columbus's location of Paradise in Aspects of Nature. See Mrs Sabine's translation (London, I849), I, 2IO-II. 
50. Aspects of Nature, I, 268-9.

5I. Aspects of Nature, I, 221 .

52. Cosmos, [translated by Mrs Sabine] (London, I846-58), II, 6I.

53. Aspects of Nature, I, 208.

54. The Voyage of the "Beagle", Everyman text (London, I906), p.396. For a discussion of the eighteenth-century myth of the South Seas Paradise see Hoxie Neel Fairchild, The Noble Savage (New York, I928), pp. I07-I2. On the pictorial tradition see "William Hodges' Paintings of the South Pacific" by Jane Roundell in the Connoisseur, $\underline{\underline{C C}}, 804$ (February I979), 85-9.

55. See Captain Cook's Journal during his First Voyage round the World ... I768-7I, edited by W. Wharton (London, I893), p.305.

56. The Voyage of the "Beagle", pp.269-7I.

57. The Voyage of the "Beagle", pp.243, 318-I9.

58. The Voyage of the "Beagle", p.363.

59. The Voyage of the "Beagle", pp.485-6.

60. The Voyage of the "Beagle", p.485.

6I. See Loren Eiseley, Darwin's Century (London, 1959), p.95.

62. In Christianity, Islam and the Negro Race (Edinburgh, I\&87) the brilliant West Indian sociologist Edward W. Blyden protests against this harmful orthodoxy: "The two races are not moving in the same groove with an immeasureable distance between them, but on parallel lines ... they are distinct but equal" (p.277).

63. "The Method of Nature" in Nature, Addresses, and Lectures, Riverside Edition (London, I886), p.I87.

64. Ludwig Leichhardt, Journal of an Overland Expedition in Australia, I844-5 (London, I847), p.266. 
65. Indeed the idea became so popular as to attract literary parody. "Do you mean", a character enquires in William Mallock's The Veil of the Temple (I904), "that we are now asked to regard ourselves not only as the children of monkeys, but as the grandchildren of beans and potatoes" (London, I906, p. 236).

66. Hence the words of the Offertory: "Deus, qui humanae substantiae dignitatem mirabiliter condidisti".

67. Charles Rycroft, A Critical Dictionary of Psychoanalysis (London, I96\&), p. I26.

68. "Man lives according to his own idea of himself", Lawrence observes in Kangaroo (London, I923, p.295); and in the case of an individual with a deep-seated belief in the innate goodness of man it is reasonable to suppose that projection would reflect the tokens of an unfallen world as well as educe the marks of personal depravity.

69. The Prelude (I850), I, lines 357-400. See the text edited by Ernest de Selincourt, revised by Helen Darbishire (Oxford, I959), pp. $23-6$.

70. Ludwig Feuerbach, The Essence of Christianity, translated by George Eliot (New York, I957), p.5. 
II. Crusoe, Desert Isle Ventriloquist

I. In the preface to Familiar Letters, his first substantial publication, Samuel Richardson appointed himself the task of describing "the social, and relative duties". See Familiar Letters, edited by Brian i. Downs (London, I928), xrvii.

2. The account given by Ian Watt in The Rise of the Novel (London, I957) remains the most influential. For a oritical survey of more recent contributions in this field see Pat Rogers, The Augustan Vision (Iondon, I974), pp.245-54.

3. All references to Robinson Crusoe are to the text edited by J. Donald Crowley (London, I972), which has the same pagination as the later World's Classics text (Oxford, I98I).

4. See Pat Rogers, Robinson Crusoe (London, I979), pp.96-IOI.

5. See Robinson Crusoe, pp.IO9, II2, II9, I80-I, as well as pp. I42-4.

6. See i.B. Carnochan, Confinement and Flight (Berkeley, I977), pp.29-45. Though indobted to this reading I disagree with the view that Crusoe's despair is largely a matter of pretence.

7. "The Garden", lines 6I-4.

8. Collected in Perry Miller's antrology The American Puritans, (New York, I956), p.I7, my italics.

9. Psalm 78:I9.

I0. A Midsumer Night's Dream, V.i.2-22. 
II. George A. Starr, Defoe and Spiritual Autobiography (Princeton, I965): pp. 74-I25 are on Robinson Crusoe.

12. From The Life and Strange Surprizing Adventures of Mr D... De F..., of London, Hosier, colleoted in Defoes The Critical Heritage, edited by Pat Rogers (London, I972), p.4I.

I3. The Pilgrim's Progress (I678), edited by James Wharey (Oxford, I928) pp 36-7.

I4. The Pilgrim's Progress, p.263.

I5. Chapters Five and Twelve of Bryan Little's biography of Woodes Rogers, Crusoe's Captain (London, I960), provide a valuable supplenent to the discussion of Robinson Crusee in the standard work on Defoe's sources, A.W. Secord's Studies in the Narrative Method of Defoe (Urbana, I924). See also Pat Rogers, Robinson Crusoe, pp.I6-34.

I6. Woodes Rogers, A Cruising Voyage Round the World (London, I7I2), p.I26.

I7. A Cruising Voyage, p. I26.

I8. A Cruising Voyage, p. I28.

19. The Englishman: A Political Journal by Richard Steele, edited by Rae Blanchard (Oxford, I955); No. 26 ( 3 December I7I3), pp. I07-8.

20. The Englishman, P.I08.

2I. An Essay on Man, Epistle I, lines 5-8. In the one-volume edition of the Twickenham text, edited by John Butt (London, I963), pp.503-4.

22. See, for example, J.W. Jones's edition of Divers Voyages Touohing the Discovery of America, translated and edited by Richard Hakluyt (New York, I850, reprinted [I97I]), p.I02.

23. The Pilgrim's Progress, p.59.

24. The Pilgrim's Progress, P.I26. 
25. Defoe's acquaintance with Locke's works is widely assumed. The section on human identity in An Essay Concerning Human Understanding (Book II, Chapter XXVII, paragraphs 5-I0) contains the account (which Locke surprisingly found credible) of a "very intelligent rational" parrot observed by a traveller in Brazil. Many supposed this bird possessed by the devil. See the text edited by A.C. Fraser (Oxford, I894), I, 446-8. Poll shows no sign of special gifts. It is striking, however, that Crusoe should remark that any visitor to the island would, on hearing Poll, "certainly believe it was the Devil" (p.I80).

26. A General History of Discoveries and Improvements (London, $7726-7$ ). In this treatise Defoe argues that exploratory navigation is the "parent of trade" ( $p .32)$, and supplies an elaborate history of technological development ever since the Flood.

27. In his essay "Of the Caniballes" Montaigne asks whether it is any worse to eat the body of a dead enemy than to torture the living in the name of religion. 
I. See John J. Richett1, Defoe's Narratives (Oxford, I975), p.83.

2. All quotations from The Life, Adventures and Piracies of the Famous Captain Singleton are from the Everyman text, edited by James Sutherland (London, I963).

3. "On Poetry: A Rapsody", The Poems of Jonathan Swift, edited by Harold Williams (Oxford, I937), II, 645. Gary J. Scrimgeour, "The Problem of Realism in Defoe's Captain Singleton", Huntington Library Quarterly, XXVII (I963), 2I-38 (p.23).

4. See particularly The Principall Navigationg(Glasgor, I903-5), IX, 287 ; also VIII, $376,453$.

5. John R. Moore, Daniel Defoe: Citizen of the Modern World (Chicago, I958), p. 252 .

6. "Captain Avery and Captain Singleton: Revisions of Popular Legend": Defoe's Narratives, Chapter III; for the quotation see p.78.

7. Jure Divino (London, I706), p.I.

8. Leviathan, Chapter XIII. In The English Works of Thomas Hobbes, edited by Sir William Molesworth (London, I839-45), III, II3-I4.

9. From "Human Nature", The English Works of Thomas Hobbes, IV, 72 .

I0. M. van Wyk Smith, "The Origins of Some Victorian Images of Africa", English in Africa, VI, I ( I979), I2-32. The quotation from the Atlas Geographus is given on p.I5; the italics are mine.

II. Atlas Maritimus et Commeroialis (London, I728); for Defoe's account of Afrios see pp.236-76, for the quotation p.237.

I2. Defoe refers to Afrioan agrioulture in Captain Singleton (p.87) and indeed in the Atlas itself (p.238). Leviathan in The English Works, III, II3. 
I3. For an excellent summary of Defoe's relation to Hobbes see Maximillian E. Novak, Defoe and the Nature of Man (Oxford, I963), pp.I4-I9.

I4. Novak prefaces a quotation from Defoe's The Political History of the Devil (I726) with the remark: "the picture which Defoe draws of the condition of the human race after the Flood is similar to Hobbes's state of nature". Defoe and the Nature of Man, p.I6.

I5. Robinson Crusoe, edited by J.D. Crowley (Oxford,I972), see particularly pp.92,99.

I6. See, for example, a passage on the Peruvians in A New Voyage Round the Forld (Iondon, I725), I, 202. Such instances are, however, the exception rather than the rule. Later in the same tert Defoe retracts his generous primitivism (II, 78); and, as Novak remarks: "in the majority of his writings he pictured the savage as an inferior being, condemned to a bestial life on earth and to eternal torment after death" (Defoe and the Nature of Man, p.42).

I7. A Review, III, 43Ia. 2uoted by Novak, Defoe and the Nature of Man,p.I5. I8. See Leviathen in The English Works, III, II7-I8: Captain Singleton, pp.66,85,92; and for references to other "Natural Laws", pp.I9I,228,266.

I9. Leviathan in The English Works, III, I26-7.

20. Leviathan in mhe English Works, III, I44.

2I. Defoe began work on his Atlas in I723-4. See Peter Earle, The World of Defce (London, I976), p.296. Atlas Maritimus, p.252.

22. John R. Moore traces the tale of the Portuguese explorers to the pages of the London Gazette (see Citizen, pp.252,379), and he is followed here by Scrimgeour ( $p .36)$; in each case the reference is wrongly given. Although many critice have noted Defoe's reference 
to "Mr Freeman" in the Atlas Maritimus the historioal identity of Mr John Freeman, Manager of the Royal African Company at Sherbro, bas not till now been established.

23. K.G. Davies, The Royal African Company (London, I957), p.256.

24. On Defoe's conneotions with the Royal Afrioan Company see Peter Earle (pp.I3I-3) and John R. Moore (p.289).

25. Novak comments on the tale of Valentine and Orson in his essay "The Wild Man Comes to Tea", collected in The Wild Man Within, edited by Edward Dudley and himself (Pittsburgh, I972), p.I86.

26. The archives of the Royal African Company are kept among the records of the Treasury in the Public Record Office. References for the last paragraph are as follows: T. 70/5, ff. I9a, 23b, 3Ib, 3Ia, I9a, I9b, $56 a, 3 I b, 45 b, 54 b, 76 b, 69 a, 72 a, 86 b$, I07a.

27. T. 70/5I ff. $265-76$.

28. T. 70/I4 ff. 596, 65b; Atlas Maritimus pp. 238, 252; Captain Singleton, pp. I06-7.

29. Srift's violent subversion of Sir William Petty's mercantilist tracts in A Modest Proposal provides perhaps the finest of many examples of the Augustan protest. The exactitude of Swift's reference is seldom appreclated. See The Economic Writings of Sir William Petty, edited by C.H. Hull (Cambridge, I899), I, $244,267,308,335-7,346$.

30. A New Voyage Round the Horld (Iondon, I725), I, 200.

3I. A New Voyage, I, II5.

32. The World of Defoe, p.54.

33. The Commentator, XI (20.5.I720), quoted in The World of Defoe, p.205.

34. A General Hiatory of Discoveries and Improvements (London, I726-7), pp. $80,92$. 
35. A Review, III, 1i (3.I.I706), collected in Daniel Defoe, edited by James Boulton (London, I965), p.I20-I.

36. A General History, p.I.

37. Mere Nature Delineated (London, I726), p.6I. See Novak in The Wild Man Within, p.I97.

38. The Reformation of Manners (London, I702), p.I7. For an account of Defoe's attitudes to slavery seo Peter Earle, pp.67-70.

39. A Review, VII (6.3.I7II), p.59I; quoted by Scrimgeour, p.35.

40. "The Life and Strange Surprizing Adventures of Mr D... DeF..." (I7I9), collected in Ioan Williams' The Novel and Romance (London, I970), see pp.62-3.

4I. An Essay upon Projects (London, I702), p.I04. An Essay upon the Trade to Africa (London, I7II), p.37. 


\section{Melville's Happy Valley}

I. All references to Typee are to the Penguin, edited by George Woodcock (Harmondsworth, I972). The text is substantially based on the Northwestern-Newberry edition of I968.

2. In the introduction to his edition of Typee George Woodcock remarks on Melville's debt to Defoe and Swift. He acutely observes: "The literary convention within whioh Melville worked was that of the eighteenth-century imaginary voyage modified by a romantic conception of primitive man derived from Rousseau", pp.I7-I8.

3. For a succinct account of Melville's experiences in the Marquesas see Leon Howard, Herman Melville: A Biography (Berkeley, I95I), pp.50-4.

4. See The Journals of Captain James Cook, edited by J.C. Beaglehole, II, The Voyage of the "Resolution" and "Adventure" I772-I775 (Cambridge, I969), pp.372-5.

5. See, for example, the passage in which Crusoe explicitly relates his divergent responses to the island to his conversion: Robinson Crusoe, edited by J. Donald Crowley (Oxford, I $\mathrm{cI}$ ), po.II2-I3.

6. Compare, for example, the description of Crusoe shattering the silence that has reigned since "the Creation of the World" when he fires his gun. Robinson Crusoe, pp.52-3.

7. Edgar A. Dryden makes this point in the course of an interesting discussion of Tommo's psychosomatic injury in Melville's Thematics of Form (Baltimore, I968), pp.40-3. 
8. The allusion would not have been lost on Melville's readers. One reviewer conmented: "the Happy Valley of the gentle cannibals compares very well with the best contrivances of the learned Dr Johnson to produce similar impressions" (New York Daily Tribune, 4 April I846). See Jay Leyda, The Melville Log: A Documentary Life of Herman Melville I8I9-I89I (New York, I969), I, 209 .

9. References to Rasselas are to the text edited by Geoffrey Tillotson and Brian Jenkins (Oxford, I977). See p.4 and elsewhere.

IO. See Moby Dick Chapter XII: in the text edited by Charles Feidelson, Jr. (Indianapolis, I964), pp. ¿8-90.

II. The Dunciad, Book IV, lines 293-4. In the one-volume edition of the Twickenham text, edited by John Butt (London, I963), p.782.

12. Windsor-Forest, line 406. In the one-volume Twickenham text, p.2IO.

I3. See Gulliver's Travels, edited by Peter Dixon (Harmondsworth, $1973), \mathrm{p} .343$.

I4. A Sentimental Journey through France and Italy in The Works of Sterne (New York, I900), II, 236.

I5. Johnson had translated A Voyage to Abyssinia by Father Jerome Lobo, A Portuguese Jesuit from the French of Le Grand in 1735 . See Donald Lockhart's article "'The Fourth Son of the Mighty Emperor': The Ethiopian Background of Johnson's Rasselas", PMLA, LXXVIII $(1963), 516-28$. 
I6. See James Boswell, The Life of Samuel Johnson, edited by Roger Ingpen (Bath, I925), I, 5I2.

17. James Bruce, Travels to Discover the Source of the Nile in the Years I768-73 (Edinburgh, I790), III, 598.

Ic. Compare Johnson's remark, made in the course of a discussion of David Hume, "The human mind is so limited, that it cannot take in all the parts of a subject". Boswell, I, 270.

I9. Boswell, II, 774 .

20. Amhara is numbered among the inferior paradises in Paradise Lost see Book IV, lines 280-4. In Kubla Khan the relation between Mount Abora and the damsel's song parallels that between the creations of Kubla Khan and the poet.

2I. In his Discours sur l'origine et les fondements de l'inégalité Rousseau writes, "the greater part of our ills are of our own making, and ... we might have avoided them all by adhering to that simple, uniform and solitary manner of life which nature originally prescribed". See A Dissertation on the Origin and Foundation of the Inequality of Mankind, collected in The Miscellaneous Works of Mr J.J. Rousseau, translated from the French in 1767 (London, I767), I, I74.

22. The Miscellaneous Works, I, I54,I56,I60.

23. The Miscellaneous Works, I, I97-8.

24. The Miscellaneous Works, I, I54,I74.

25. The Miscellaneous Works, I, 205. 
26. On this point see Geoffrey Symcox's essay "The Wild Man's Return", collected in The Wild Man Within, edited by Edward Dudley and Maximillian E. Novak (Pittsburgh, I972), p.227.

27. This convention is called "the negative formula" by Harry Levin in The Myth of the Golden Age in the Renaissance (New York, I969), p.20.

28. Typee, pp.203-4; The Miscellaneous Works of Mr J.J. Rousseau, I, 205 .

29. So much so, indeed, that it is questionable whether the massive restoration of essay passages from the original manuscript in the Northwestern-Newberry edition of I968 (on which the current Penguin edition is largely based) is altogether an advantage to the text.

30. James Fenimore Cooper, The Prairie (San Francisco, I950), p.2I0.

3I. The Prairie, p.2I2.

32. Luis Vaz De Camoens The Lusiads, Canto IX: translated and edited by C. Atkinson in the Penguin text (Harmondsworth, I952), pp.209-I7.

33. Charles Darwin, The Voyage of the "Beagle", Everyman text, (London, I906), p.398.

34. See Typee, p.200, where the statement of the paradox is particularly explicit in the text.

35. From The Marriage of Eeaven and Hell; see The Complete Writings of William Blake, edited by Geoffrey Keynes (London, I966), p.I58.

36. The Miscellaneous Horks, I, 229-3I.

37. The Miscellaneous Works, I, I67 .

38. The Confessions of Jean-Jacques Rousseau, Book Two. In the Penguin text, translated by J.M. Cohen (Harmondsworth, I953), pp.63-4. 


\section{Captain Ahab and the Albatross}

I. Charles 0lson, Call me Ishmael (San Francisco, I947), p.I3.

2. In a letter to Amy Lowell written on 23 August I9I6. See The Letters of D.H. Lawrence, II, edited by G.J. Zytaruk and J.T. Boulton (Cambridge, I98I), p.645.

3. All references to Moby Dick are to the text edited and annotated by Charles Feidelson, Jr. (Indianapolis, I964). For Euroclydon see Acts $27: I 4$.

4. Leon Howard comments on Melville's debts to Carlyle and Byron in his excellent account of the evolution of Moby Dick, see Herman Melville: A Biography (Berkeley, I95I), pp.I62-79. He is more concerned, however, with specific matters of literary influence than with a context of ideas. In Nelville's Quarrel With God (Princeton, I952) Lawrance Thompson is concerned with questions of belief but the treatment is largely internal.

5. See The Letters of Herman Melville, edited by M.R. Davis and H.H. Gilman (New Haven, I960), p.I30.

6. Mardi began the same way too, but the voyage through the South Seas became increasingly the vehicle of allegory. See Leon Howard, Herman Melville, pp.II3-I5.

7. Ian Cameron, To the Farthest Ends of the Earth: The History of the Royal Geographical Society I830-I980 (London, I980), p.I6.

8. In Mrs Sabine's EnElish translation Humboldt's full title runs "Aspects of Nature in Different Lands and Different Climates;with Scientific Elucidations".

9. Alexander von Humboldt, Cosmos, [translated by Mrs Sabine] (London, I846-58), II, 68 .

I0. Alexander von Humboldt, Aspects of Nature (London, I849), I, 2II; 
quoted by Douglas Botting in Humboldt and the Cosmos (London, I973), p.40.

II. Quoted by Botting, p.40.

I2. Cosmos, I, xviii.

I3. Lytton Strachey, Book and Characters (London, I922), p.4I.

I4. See Charles Rycroft, A Critical Dictionary of Psychoanalysis (London, I968), p.I05.

I5. Addressed to Nathaniel Haw.thorne from Pittsfield on I June I85I. The Letters, pp.I30-I. Davis and Gilman remark that Melville's exact source for the quotation from Goethe remains to be discovered, but suggest a likely passage from Carlyle.

I6. "Hawthorne and his Mosses" (I850), collected in Hawthorne: The Critical Heritage, edited by J. Donald Crowley (Iondon, I970), p.II6.

17. For a valuable account of the history of this idea see Lilian R. Furst on "The 'Esemplastic' Power" in her Romanticism in Perspective (New York, I969), pp.I36-47.

18. Alan Sandison, The Wheel of Empire (London, I967), p.58. His quotations are from René Wellek's "Romanticism Re-examined" in Romanticism Reconsidered, edited by Northrop Frye (I963), p.I30; and Prom Albert Guerard's "The Logic of Romanticism" in Essays and Criticism, III (I957).

19. Keats advances this distinction in his letter to Bailey (22 November I8I7). The Letters of John Keats, edited by H.E. Rollins (Cambridge, I958), I, I84; see also I, I93,387. Davis and Gilman in their edition of Melville's letters trace the quotation from Goethe to his "Generalbeichte". J.G. Fichte proposes this view in The Vocation of Man. For a brief but lucid aocount 
see Sandison's The Wheel of Empire, pp.49-5I.

20. Biographia Literaria, Chapter XII. In the Everyman text, edited by George Watson (London, I965), see pp.I37-8.

2I. The idea is basic to the structure of Browning's "A Grammarian's Funeral"; to Ibsen's Brand, John Gabriel Borkman and When He Dead Awaken; and to Olive Schreiner's allegory of the search for truth in The Story of an African Farm, separately published as "The Hunter" in Dreams (London, I890). The metaphor is in wide use in Nietzsche's writing but for a particularly explicit passage see Ecce Homo, translated by A.M. Ludovici (London, I9II), Preface (Section 3), pp.2-3. Sir Leslie Stephen avails himself of the analogy in an essay entitled "Heredity", see Social Rights and Duties (London, I896), II, 34 .

22. See Jay Leyda, The Melville Log (New York, I969), I, 27 I.

23. See "Dejection: an Ode", stanza VI. Coleridge: Poems, edited by John Beer (London, I974), p.282.

24. All quotations from The Rime of the Ancient Mariner are from the text edited by John Beer, pp. 77 3-89.

25. R. Penn Warren, "A Poem of Pure Imagination" (I946) collected in Selected Essays (London, I964), pp.I99-305.

26. See J.L. Lowes, The Road to Xanadu, Sentry edition (Boston, I955), p.276.

27. For some interesting conjecture on the context of Melville's remark see Melville's Quarrel ith God, op.I40-I.

28. After witnessing the might of Leviathan Job declares: "I know that thou canst do every thing, and that no thought can be withholden from thee". Job $42: 2$.

29. See Charles Darwin, The Voyage of the "Beagle", Everyman text 
(London, I906), pp.364-70. Melville visited the Galapagos Islands in I84I, six years after Darwin, and bought a copy of The Voyage in I847 - though he may have read it earlier: see The Melville Iog, I, I80, 240 .

30. The Encantadas, in The Complete Stories of Herman Melville, edited by Jay Leyda (New York, I949), p.58. 


\section{Conrad Dismantles Providence}

I. All references to Conrad are to Dent's Uniform Edition (Iondon, I923-8), the pagination of whioh is identical to all later Dent editions and also to the Doubleday edition (I924).

2. Falk, in Typhoon and Other Stories, p.2II.

3. In a letter to $\mathrm{i}$. Blackwood Conrad wrote, "I never did set up as an authority on Malaysia. I looked for a medium in which to express myself". Joseph Conrad: Letters to William Blackwood and David S. Meldrum, edited by W. Bleckburn (North Carolina, I958), p. 34 .

4. Ian ilatt, Conrad in the Nineteenth Century (London, I980), p.I54.

5. A Personal Record, p.92.

6. Joseph Conrad's Letters to R.B. Cunninghame Graham, edited by C.T. Watts (Cambridge, I969), p.56.

7. I4 January I898. Letters to Cunninghame Graham, 0.65 .

8. Although mhe Outcast is among Conrad's relatively neglected works there is some valuable commentary on it. In his definitive account of the novel's sources in Conrad's Eastern World (Cambridze, I966), Norman Sherry calls attention to the recurrent concern with patronage (p.II2). R. Roussel in The Metaphysics of Darkness (Baltimore, I97I) speaks of the subjective imprisonment undergone by the novel's major figures (pp.52-5); and Bruce Johnson in Conrad's Models of Mind (Minneapolis, I97I), while examining Conrad's probing of the atrophied will, touches on the theme of projection, though he does not himself use the term (pp.20-3).

9. Almayer's Folly, P.I92. 
I0. Almayer's Folly, p.I79. Norman Sherry mentions the fact that William Lingard (on whom Conrad's Tom Lingard is based) owned a boat named Nina : Conrad's Eastern Forld, p.90. Conrad would certainly have been aware of the reference to Columbus.

II. Lord Jim, p.323.

I2. Willens eventually begs Lingard to give him asylum on a "deserted island" (p.274).

I3. Unsigned review: Daily Chronicle, I6 March 1896. See Conrad: The Critical Heritage, edited by Norman Sherry (London, I973), p.63.

I4. In a letter to Hunphrey Milford, I5 January I907. See Moby Dick As Doubloon, edited by H. Parker and E. Hayford (New York, I970), p.I23.

I5. See Spectator, 30 May I896, in Critical Heritage, p.79.

I6. By Omar, Abdullah, Lakamba, Almayer and Lingard.

I7. 8 February I899. Letters to Cunninghame Graham, p.II7

I8. See Barbara Hardy, The Appropriate Form: An Essay on the Novel (London, I964, revised I97I), p.53.

I9. References to R.M. Ballantyne's Coral Island are to the Everyman text (London, 1907, reprinted I954).

20. Author's Note to An Outcast, ix.

2I. In Speaker, I2 November I904. See Critical Heritage, p.I77.

22. Almayer's Folly, p.I65.

23. "Praise, my soul, the King of Heaven", written by H.F. Lyte in I834. Hymns Ancient and Modern (London, I922), No.298, p.326. 24. Author's Note, ix. 25. Royal Roussel, p. 32 . 26. Bmuce Johnson cites Schopenhauer in discussing An Outcast but in a quite different connection: see Conrad's Models of Mind, pp.9, 
II,23. Johnson takes the view that willems finds a refuge in the wilderness from competition and the exercise of will (p.I6). The narrator makes it clear, however, that Willems is no shirker and that he particularly regrets his lost chances: "He gnashed his teeth when he thought of the wasted days, of the life thrown away ... He heard the reproach of his idleness in the murmurs the river ..." (p.65).

27. Arthur Schopenhauer, The horld as Will and Idea, translated from the German by R.B. Haldane and J. Kemp, (London, I896), I, 256. 28. Bruce Johnson, p.I5.

29. "Naboth" from Rudyard Kipling's Life's Handicap (London, I896), p.340. 30. The "Man-bep" theme is especially to the fore in the exposition of Barbie's faith and of Teddie's death (see, particularly, The Towers of Silence (London, I97I), p.364 and The Day of the Scorpion (London, I968), p.404); it inheres also, of course, in the central icon of the jewel in the crown.

3I. Under Western Eyes, p.8.

32. See Under Western Eyes, pp.I03,263,245,28I-2.

33. Under Nestern Eyes, p. 350 .

34. See Under Western Eyes, pp.289,296, 30I.

35. Almayer's Folly, p.66.

36. In Almayer's Folly we seo Lingard drinking in "the approbative shouts of his half-intoxicated auditors" (p.23).

37. Al Pred Russel Wallace, The Malay Archipelago, (London, I869), I, I46. My italics.

38. The Malay Archipelago, I, 397. Chapters VII and XVII have a particular bearing on this theme.

39. The Malay Archipelago, I, 397-8. 
40. The Malay Archipelago, I, 402 .

4I. The Malay Archipelago, I, I44, I3I.

42. The Malay Archipelago, I, 402 .

43. Thomas Hardy, Tess of the DUrbervilles (I89 I) (London, I974), p.66.

44. Sigmund Freud, "The Justification for Detaching from Neurasthenia

a Particular Syndrome: The Anxiety-Neurosis"( I894) in Collected

Papers: Volume One, translated by Joan Riviere (New York, I924),

pp.76-I06. See particularly pp.IOI-2.

45. Sigmund Freud, "Psycho-Analytic Notes upon an Autobiographical Account of a Case of Paranoia" (I9II) in Collected Papers: Volume Three, translated by Alix and James Strachey (London, I925). Freud writes: "The intensity of the emotion is projected outwards in the shape of external power, while its quality is changed into the opposite. The person who is now hated and feared as a persecutor was at one time loved and honoured" (p.424).

46. Sigmund Freud, "A Difficulty in the Path of Psycho-Analysis" (I9I7) in Complete Psychological Works: Volume Seventeen, translated and edited by James Strachey (London, I955), p.I40.

47. See Albert J. Guerard, Conrad: The Novelist (Cambridge, Mass., I978), p. 80.

48. Georges Bataille, Death and Sensuality: A Study of Eroticism and the Taboo, translated from the French (New York, I962), p.I7.

49. The Malay Archipelago, I, I20. For a good instance of the providential reading of nature see Livingstone's celebrated account of lion attack: he sees the release of the victim's adrenalin as "a merciful provision by our benevolent Creator for lessening the pain of death". Missionary Travels and Researches in South Africa (London, I857), p.I2.

50. Richard Curle's testimony is quoted by Norman Sherry in Conred's Eastern World, pp.I4I-2. 


\section{The Hidden Man}

I. Joseph Conrad: Life and Letters, edited by G. Jean-Aubry (London, I927), II, 338. In a letter to F.N. Doubleday Conrad stresses the aesthetic unity of the volume.

All references to Conrad are to Dent's Uniform Edition (London, I923-8), which has the same pagination as later Dent editions.

2. Arthur Schopenhauer, The World as Will and Idea (I8I9, first English translation IC83), translated by R.B. Haldane and J. Kemp, fourth edition (London, I896). Of particular relevance here is the Fourth Book, "The Assertion and Denial of the Will". In a short memoir on Conrad written in I924 John Galsworthy recalls: "Of philosophy he had read a good deal ... Schopenhauer used to give him satisfaction twenty years and more ago". Castles in Spain (London, I927), p.9I. See also C.T. Watt's introduction to Joseph Conrad's Letters to R.B. Cunninghame Graham, p.25.

3. Joseph Conrad's Letters to R.B. Cunninghame Graham, edited by C.T. Watts (Cambridge, I969), p.70. For a comparable passage in The World as Will and Idea see I, 400-I.

4. Edward Garnett, Letters from Conrad, I895-I924 (London, I928), xii.

5. Youth, pp.26,30.

6. The World as will and Idea, pp.456,454.

7. See Author's Note, xi.

8. Youth, pp.37,4I.

9. Youth, p.33.

In "Geography and Some Explorers" (I924) Conrad recalls that Sir Leopold McClintock's account of the recovery expedition, The Voyage of the Fox (I859), was among the favourite books of his childhood. 
The expedition was funded by Franklin's widow and Sir Leopold breathes no word of cannibalism, referring only to the depredations of "large and powerful animals", (London, I908), p.223. Conrad refers in his essay, however, to the gradual revelations of the crew's fate in this "darkest" of dramas, Last Essays, pp.IO-II. The revelations actually predate MoClintock, see John Rae, The Melancholy Fate of Sir John Franklin and his Party (London, I854).

I0. Youth, p.37.

II. H.M. Stanley, Through the Dark Continent (I878) (London, I907), p.449.

I2. "Geography and Some Explorers", Last Essays, p.I7.

13. Uuoted by Neal Ascherson in The King Incorporated: Leopold II in the Age of Trusts (London, I963), p.248.

I4. See Norman Sherry, Conrad's iestern Norld (Cambridge, I97I), pp. I2, I4.

I5. Conrad refers, in the course of his essay, to Park, Barth, Burton, Speke, Iivingstone and Stanley.

I6. Schweinfurth, The Heart of Africa, translated by Ellen Frewer (London, I873), I, I3-I5. Appalled by his first view of colonial exploitation on a Eypsum mine at Gimsah, the explorer compares the workers to "beasts ... caged in hopeless imprisonment" and equates fumes of sulphur rising from the site with the fires of hell. The passage is comparable in many respects to Marlow's description of the company station with its grove of death.

I7. H.M. Stanley, In Darkest Africa (London, I890). Barttelot, a possible model for Kurtz (see Ian Watt, Conrad in the Nineteenth Century, pp. I42-3) seems not to have heeded the lecture on forbearance ( $p p .78-8 I)$, if it was ever given, for his death was 
caused by a fit of pique (p.303), and rumours of his excesses were rife at the rear camp $(p .298)$. Some of Stanley's descriptive passages are remarkably close to Conrad's: see, for example, In Darkest Africa, pp.355,352-3,I23, 167. For sea and beast similes in Heart of Darkness see pp.86,92, I56; 96,I05. Compare also the passages from Almayer's Folly (I895) and In Darkest Africa (IE90) already quoted on pp.169, 20.

I8. Schweinfurth quotes the proverb, "Then fame paints a serpent, she attaches feet to its body". His purpose, in his own metaphor, is to remove the tail that mythology has appended to all things African: see Heart of Africa, II, I76; I, 68. For Stanley's remarks see In Darkest Africa, pp.402,404,503.

19. Philip D. Curtin, The Image of Africa (London, I965), p.207.

20. For an interesting discussion of this topic see $\mathrm{H}$. Alan Cairns, Prelude to Imperialism: British Reactions to Central African Society I840-I890 (London, I965), Chapter 3, "Contemporary Ancestors".

2I. The Heart of Africa, II, 2,I7,I27.

22. See Richard Burton, The Lake Regions of Central Africa ( I860) (London, I96I), II, 324; and Livingstone's Private Journals I85I-53, edited by I. Schapera (London, I960), p.I56.

23. In Darkest Africa, pp.333-4,516,87,96.

24. For an account of this theme see Leo J. Henkin, Darwinism in the English Novel I860-I9 I0 (New York, I940, røprinted I963), Chapter 9, "The Anthropological Romance".

25. Ian Watt, Conrad in the Nineteenth Century (London, I980), p.I66.

26. Richard Eurton, First Footsteps in East Africa, Memorial Edition (London, I894), I, 4 .

27. First Footsteps, I, 5,27. The line from Almanzor's first important 
speech in The Conquest of Granada reads, "I am as free as nature e'er made man".

28. Richard Burton, Zanzibar: City, Island, and Coast (London, I872), $\stackrel{I}{=}$ I7 .

29. The Matabele Journals of Robert Moffat I829-I860, edited by J.P.R. Wallis (London, I945), pp.II8-I9.

30. The Heart of Africa, I, 33I.

3I. Richard Burton, A Mission to Gelele King of Dahome, edited by C.N. Newbury (London, I966), pp.22I,285.

32. A Mission to Gelele, p.230.

33. A Mission to Gelele, pp.22I, 233,223n.

34. See Christopher Hibbert, Africa Exolored: Europeans in the Dark Continent I769-I889 (London, I982), pp.279,203; and Burton's First Footsteps, I, 28 .

35. See Fawn Brodie, The Devil Drives: A Life of Sir Richard Burton (New York, I967), pp.I5-20, 290-9.

36. Swinburne quoted by Alan Moorehead in The White Nile (London, I960), p.20; Speke by Hibbert in Africa Explored, p.209.

37. In the preface to one of his own poems. See The Devil Drives, pp.276,278.

38. See The White Nile, p.20.

39. Arthur Symons quoted by Hibbert in Africa Explored, p.203; Frank Harris, Contemporary Portraits (London, I9 I5), pp.I6́6-7.

40. For an account of this trend see Bernard Porter, Critics of Enpire (London, I968).

4I. See In Darkest Africa, pp.242,45I. Stanley also spells out the suffering entailed by the "trade" in ivory: "for every five pounds a hut has been burned; for every two tusks a whole village 
has been destroyed ... It is simply incredible that, because ivory is required for ornaments or billiard games, the rich heart of Africa should be laid waste" ( $p$. I43).

42. See The King Incorporated, particularly Chapters 9 and IO.

43. See Jack Simmons, Livingstone and Africa (London, I955), p.I52 and The King Incorporated, p.92. Livingstone was buried in I874; Leopold made his speech to an international audience in Brussels two years later.

44. See The King Incorporated, pp.94,88, II3.

45. See Edward Glave, "Cruelty in the Congo Free State" in The Century Magazine, LIY, 5(September I897), p.709.

46. Descriptions are legion: for plates see, for example, John Speke, Journal of the Discovery of the source of the Nile (Edinburgh, I863), p.I02; Verney Cameron, Across Africa (Iondon, I877), I, I66; II, I47; Iivingstone, Iast Journals (Iondon, I874), In 56.

47. Mungo Park, Travels in the Interior of Africa, (I799), edited by Ronald Miller (London, I954), pp.249,I8, 265.

48. The Last Journals of David Livingstone, edited by Horace Waller (London, I\&74), II, 92. The passage concerned is pieced together from the testimony of Chuma and Susi.

49. See Conrad's Western World, pp.30-4.

50. Quoted in Critics of Empire, p.304. For an account of the Congo Reform Society see Bernard Porter also.

5I. Quoted by S.J.S. Cookey in Britain and the Congo Question I885-I9I3 (London, I968), p.76. Casement made this comment in I903.

52. By a decree of I892, for example, Leopold excluded all private companies and traders from a large area of the Congo known as the Domaine Privé. 
53. S.J.S. Cookey notes that "company agents were free to levy what taxes they liked, to collect them by whatever means they chose, and to impose any punishment they fancied in case of a default". Britain and the Congo Question, p.I6. The agents were entitled to a percentage of the total takings as Conrad indicates, see Heart of Darkness, p.78.

54. See The Century Magazine, LIV, pp.699-7I5. Glave's stark reports are an invaluable background to Heart of Darkness. The quotation is from a letter, printed separately in the same magazine, p.796.

55. "Glave's Last Let ter", The Century Magazine, p.797.

56. The World as Will and Idea, pp.460-I. My italics.

57. Schopenhauer opens his preceding paragraph with the remark that "knowledge of eternal justice ... demands the complete transcending of individuality", p.458.

58. "Autocracy and War" in Notes on Life and Letters, pp.84, I08-9.

59. The Lake Regions of Central Africa, II, 352-3.

60. "Author's Note", $x$.

6I. C.W. Newbury in his introduction to Burton's Mission to Gelele remarks that a "major question posed by the age was whether Africa could be considered as part of the human race" (p.38). The question was raised by Burton himself in a chapter entitled "Of The Negro's Place in Nature" (left out of the new edition) where he suggests that the theory of "a great structural sulf between the black and white races" was gaining rather than losing ground in his own period. See Memorial Edition (London, I893), II, I2I, I22,I26. For some interesting discussion of this topic and of related issues such as polygenesis see Bernard Porter, Critics of Empire, Chapter 5; and P.D. Curtin, The Image of Africa, Chapters 9 and I5. 
62. The World as Will and Idea, p.47I.

63. The World as will and Idea, p.472.

64. See Conrad in the Nineteenth Century, pp.225-30.

65. Charles Dickens, A Christmas Carol in Christmas Books, Oxford India Paper Dickens (London, n.d.), po.23-4. Marley's ghost images scrooge's inner state, see p.30.

66. In a Frazer-like reconstruction of these rites, Stephen Reid argues that Kurtz should be supposed to make a ritual meal of his sacrificial victims. See "The 'Unspeakable Rites' in Heart of Darkness" in Conrad: A Collection of Critical Essays, edited by Marvin Mudrick (Englewood Cliffs, N.J., I966), p.48.

67. Letters to R.B. Cunninghame Graham, p.II6.

68. The view that the atrocities were the "natural outcome" of the system of government was taken by Pickersgill, see Britain and the Congo question, p.49; for Keir Hardie's more pessimistic view, summarized by Neal Ascherson in the quotation, see The King Incorporated, p.260.

69. T.H. Huxley, "Evolution and Ethics", Collected Essays (London, I892-5), IX, 83 .

70. For a finely areued defence of Marlow's lie see Jacques Berthoud, Joseph Conrad: The Major Phase (Cambridge, I978), pp.60-3.

7I. See "Travel" in Last Essays, p.90.

72. The climactic scene in which hlan MeKenzie makes his honourable lie reverberates with Conradian echoes. See Somerset Maugham, The Explorer, Collected Edition (Iondon,I967), pp.I52-6.

73. E.N. Forster, A Passage to India (Harmondsworth, I957), pp. I23, I25; but see the whole of Chapter I2. In Moby Dick Melville describes the sea as "an everlasting terra incognita" (p.362). 
74. D.H. Lawrence, Psychoanalysis and the Unconscious (I92I), Adelphi Library (London, I93I), pp.I3-I6, I4 .

75. For the reference to Jung see Fritz Vittels, sigmund Freud: his Personaity, his Teaching and his School, translated by Eden and Sedar Paul (New York, I924), p.I32. For Freud's theory see, for example, Totem and Taboo, translated by James Strachey (London, I950), pp.88-90.

76. For the guotation from Marx and a discussion of his relation to Darwin see aillian Beer, Darwin's Plots (London, I983), po. $57-8$.

77. To Idward Garnett, 5 June I I4. Ihe Letters of D.H. Lawrence, II, eaited by G.J. Zytaruk and J.T. Boulton (Cambridge, I $73 I$ ), pp. I82-4. In the preface to Miss Julia Strindberg relates a very similar notion of fluid identity to evolutionary theory. See August strindbers, Tight Famcus Plays, translated by Edwin Bjoriman (London, I968), pp.I06-7.

78. See T.S. Eliot's note to line $2 I$.

79. Virsinia Noolf, To the Iighthouse (London, I977), pp 99,84.

80. James Joyce, Hysses (London, I960), pp.272-4.

8I. D.H. Lawrence, The Rainbow (London, I926), 00.445-50, and p.I90. I am indebted to Sue Moclintock for pointing out this last quotation. 


\section{The Country of the Mind}

I. In A Fringe of Leaves White draws agein on the Kelly paintings when he describes Jack Chance: "He had withdrawn inside his leather mask, through the slits in which, eyes of a pale, drained blue were looking at her suspiciously ... The mask in wrinkled leather immediately set into a musted-iron visor" (London, I976, p.28I). Nolan's series on the Fraser legend undoubtedly contributed to this novel as well. There are several details in Voss that correspond to Leichbardt's account of his first expedition to Port Essington: Leichhardt himself was badly kicked by a horse, and Gilbert, the botanist of the party, was killed by a spear. White would certainly have noticed the German's interest in the mineral and crystalline, which seems far in excess of strictly scientific ends. See Jourmal of an Overland Expedition in Australia (London, I847), pp. 308-I0,435,22I. Also mentioned by inite are the journals of Eyre, and here too there are points of resemblance, particularly Baxter's wish - half-way through the journey - to abandon his leader and return. White may equally well have remembered, however, the split between Burke and his second-in-command at Menindee. See Flaws in the Glass (London, I98I), p.I03; and Edward Eyre, Journals of Expeditions of Discovery into Central Australia and Overland (London, I845), I, 378,384 .

2. All references to Voss are to the edition published by Jonathan Cape (London, I980). For the eye motif see pp.29,3I,IOI,I22, 224,4I9, apart from those cited below.

3. R.F. Brissenden, Prtrick White (London, I966, revised I969), p.25. 
4. Brian Kiernan, Patrick White (London, I900), p.5I. A striking precedent for this alternation of literal and figurative journeying exists in the third section of to the Lighthouse. Virginia woolf is one of the many twentieth-century writers whose influence White has potently assimilated.

5. The reference to "base metal" represents the first of a train of alchemical images applied to Voss's development. White's interests in this field seem to derive from his reading of Jung's Psychology and Alchemy: see Flaws in the Glass, p.I46.

6. Though this holds of many paintings in the series, I am thinking particularly of the one entitled Kelly (I954).

7. J.G. Fichte, The Vocation of Man, translated by William Smith, revised and edited by R.M. Chisholm (New York, I956), pp.I24-6.

8. The Vocation of Man, P.I28.

9. Patricia Morley refers to the "Now Testament theme of dying to sin in order to live unto God" in her discussion of Voss: see The Mystery of Unity (Montreal, I972), p.I24.

I0. See the chapter entitled "The Flight from Women" in Paul Zweig's The Adventurer (London, I974), particularly p.7I.

II. Central to the dream this image - the offered and rejected hand also recurs through the text, notably in the scene of Palfreyman's death ( $p .365)$, and in the description of the first meeting with the Aborigines:

At first the blackfellow was reluctant, but then took the hand as if it had been some inanimate object of barter, and was turning it over, examining its grain, the pattern of veins, and, on its palm, the lines of fate.

"It would seem that all human relationships hung in the balance", the narrator observes on this occasion, indicating also the generic significance that attaches to the relationship of Voss and Laura. 
I2. James Joyce, Ulysses (Iondon, I960), p.24.

I3. D.H. Iawrence, "The Crown", collected in Phoenix II, edited by Warren Roberts and Harry $\mathrm{m}$. Moore (London, I968), pp.365-4I5.

I4. A.R. Radcliffe-Erow in his pioneering essay, "The Rainbow-Serpent Myth in South-East Australia", advances the view that the Great Snake is the Aborigines' "most important representation of the creative and destructive power of nature". Oceania, I (I930), 342-7; see p.347. Principally through the character of Jackie, White gives a colourful exposition of this view: the Rainbow serpent is "gut" and "Father my father, all blackfeller" (pp.292-3), but also death-bringer - "'Snake eat, eat,' cried the black boy, snapping at the darkness with his white teeth" $(p .403)$. Voss, as befits his transition from God to man, is pictured both as the swallower and the swallowed, as Rainbow Serpent and victim, in his closing scene $(\mathrm{pp} .400,402)$.

I5. I.R. Hiatt's article, "Swallowing and Pegurgitation in Australian Myth and Rite", collected in Australian Abori zinal Mythology, edited by himself (Canberra, I975), is full of interest for the student of Patrick white. Like a postulant who emerges as an initiate from the belly of the Rainbow serpent Voss is "swallowed" $(p .400)$ by the cleft (with its "folds of grey earth") in which he completes his process of self-recognition ( .4 I4 ).

I6. Elkin notes that the initiation of medicine men taires the form of a ritualized death followed by "a rebirth and endownent with new life". For the postulant the transitional phase is often associated (as in Le Mesurier's case) with illness and madness; while the final possession of crystals (Le Mesurier has to be 
prevented from raking up the live embers in the cave) symbolizes the immanence of the Rainbow Serpent with which, because of their prismatic qualities, the crystals are linked. See A.P. Elkin, Aboriginal Men of IIigh Degree (Sydney, I945), p.I23; and The Australian Aborigines (Sydney, I943), p.226.

I7. Friedrich Nietzsche, "Maxims and Interludes, I38" from Beyond Good and Evil, translated by R.J. Hollingdale (Harmondsworth, I973), p.83.

I8. Peter Beatson calls attention to the ritual detail of the knocked-out tooth in Voss. See "The Mhree Stages: Mysticism in Patrick White's Voss", joutherly, 30 (I970), p.I2I. Other such details include Laura's metaphoric emergence from an initiation hut at the moment of her deepenins intimacy with Voss (p.64); and the imagery of metamorphosis that White apolies to Belle's marriage, and to the farewell party (pp.35I, 86-7).

I9. Of the portrayal of Sydney in the last phase of the novel G.A. Wilkes remarks, "the whole Zeitgeist has been changed by the experience [of Vosg]". See "A Reading of Patrick White's Voss" in Southerly, 27 (I967), I59-73 (p.I73).

20. See, for example, Mircea Iliade's summary of the Aranda myths of origin in Australian Religions (Ithaca, I973), pp.44-50.

2I. Sketched under the heading "Repetition of the Cosmogony" in The Myth of the Eternal Return (translated by Villard R. Trask, Princeton, N.J., I954), pp.I7-2I, this theory repeatedly returns in Eliade's writings. See, for example, Myths, Dreams and Mysteries, translated by Philip Mairet (London, I960), pp.2I8-23. 


\section{The Sacramental Wild}

I. The Eye of the Storm (London, 1973), p.378. The Warmer children base their cuit on a supposed burial ground under the floor of their holiday house on Brumby - which exactly corresponds to to Fraser Island of the atlas.

For a full exposition and criticism of the many versions of Eliza Fraser's story see Michael Alexander, Mrs Fraser on the Fatal Shore (London, I97I). White's novel is loosely based on the unlikely tale told by Bracefell, sympathetically recorded by Henry Stuart Russell in The Genesis of Queenslend (Sydney, I8\&8), and summarized by Alexander, pp.I08-23.

2. All references to A Fringe of Leaves are to the edition published by Jonathan Cape (London, I976). See pp.233,324.

3. The Eye of the Storm, Chapter 8; pp.403,382.

4. "Most of us have committed murders", Voss remarks; and adds later - "we shall be eaten by somebody eventually. By a friend, perhaps". See Voss (London, I980), pp. 25,403.

5. D.H. Lawrence, The Rainbow (London, I926), p.203.

6. D.H. Lawrence, Kangaroo, (London, I923), pp.228-9, 213.

7. Kangaroo, Chapter 8; and see pp. 165, I83-5, 294-5.

8. Kangaroo, p.I83.

9. For a discussion of White's (self-acknowledged) debt to Simone Weil see Veronica Brady "The Noveliat and the Reign of Necessity: Patrick White and Simone Heil", in Patrick White: A Critical Symposium, edited by R. Shepherd and K. Singh (Adelaide, 1978), pp.I08-I6.

IO. See C.G. Jung, Psychological Types, translated by H. Godwin 
Baynes (London, I923), pp. 525-6,55I-2.

II. For an excellent account of the Virgilian and other levels of allusion in the novel see Manly Johnson, "A Fringe of Leaves: White's Genethlicon" in Texas Studies in Language and Literature, 2I (I979), 226-39. There are several valuable articles in this volume which is wholly given over to white.

I2. Edward W. Said, Orientaliam (London, I978), p.305.

I3. Janet Lewis, The Invasion (Chicago, I960), p.76.

14. See, for example, Baldwin Spencer, Wanderings in Wild Australia (London, I928), I, 203; and his The Arunta (London, I927), p.495; N.N. Thomas, Natives of Australia (London, I906), p.I09. In The Man-Eating Myth (New York, I979), W. Arens challenges the reliability of all evidence relating to ritual cannibalism but repeatedly overlooks testimony of considerable weight in favour of his men-of-straw. He quotes with approval Livingstone's comments on alleged cannibalism among the Hanyuema, "A Scotch jury would say, 'Not proven'", and goes on to generalize from it - "his experienced testimony should be of some value" ( $p .85)$. Livingstone did, however, believe in the existence of cannibalism in Africa, and in a late entry of his Journal, not many pages on, accepts and records a graphic report of the practice among the Nanyuema who "seem to eat their foes to inspire courage". See The Last Journals of David Livingstone (London, I874), II, 98, I48; also II, 48-9,II7-I8. Firsthand evidence though uncommon is not as rare as Arens makes out; the Fraser material provides an instance in the testimony of John Baxter, seo Michael Alexander's book, pp. 57-8. 
I5. B.A.L. Crenstone, The Australian Aborigines (London, I973), p.28.

I6. For a different interpretation of Ellen's cannibal rite see "A Severed Leg: Anthropophagy and Communion in Patrick white's Fiction" in Southerly, 40 (I980), 399-4I7, where Don Anderson takes the austerely psychoanalytic view that Ellen in "eating the phallus, in partaking of the insistent thigh ...' 'kills' the father-totem within her" (p.4I5). For Anderson it is the leg rather than the act of ingestion which seems important. One recorder of South Queensland rites notes, though, that "most parts of the body are eaten, the thighs being the bonne bouche". Natives of Australia, p.IO9.

I7. Voss, p.I80.

I8. The Ballad of Reading Gaol, stanza 7. See The Works of Oscar Wilde, edited by G.F. Maine (London, I948), p.823.

I9. Friedrich Nietzsche, Beyond Good and Evil, translated by R.J. Hollingdale (Harmondsworth, I973), Section 229 , p.I40.

20. Dusklands (Johannesburg, I974), pp.I04,I06.

2I. According to Bracefell Mrs Fraser withdrew her promise on approaching the colony - threatening, indeed, to complain of him instead - and so be returned to the tribe. Mrs Fraser on the Fatal Shore, pp.II3-I4.

22. For an account of J.M. Coetzee's strategy in this regard see my article "Dusklands: A Metaphysics of Violence" in Contrast 53, XIV, I (I982), 26-38.

23. White quotes "A perfect Woman, nobly planned, / To warn, to comfort, and command" from "She was a Phantom of Delight" among the novel's epigraphs. 
24. The Notebooks of Simone Weil, translated by Arthur Wills (Iondon, I956), I, 235.

25. Simone Weil, Oppression and Liberty, translated by Arthur wills and John Petrie (London, I958), p.I08.

26. William Faulkner, The Bear, collected in Go Down Moses (Harmondsworth, I960), p.I77. 


\section{Bibliography}

Unless otherwise stated, place of publication is London.

A format based upon the recommendation for bibliographical entries in the Modern Humanities Research Association Style Book ( I978) has been adopted.

I. Exploration and Related Works

II. Social and Anthropological Background

III. Philosophical and Psychological Background

IV. Critical Works

V. Literary Texts

I. Exploration and Related Works

Alexander, Michael, Mrs Fraser on the Fatal Shore, I97I

Axelson, Eric, Congo to Cape: Early Portuguese Explorers, 1973

Bagrow, Leo, History of Cartography, rev. R.A. Skel ton, I964

Baker, Sir Samuel H., The Albert N'yanza, Great Basin of the Nile,

2 vols, I\&86

Barrow, Sir John, An Account of Travels into the Interior of Southern Africa in the years $I 797$ and I798, 2 vols, I80I-4

Beaglehole, J.C., The Exploration of the Pacific, I9 34

Bennett, Josephine, The Rediscovery of Sir John Mandeville, New York, 1954

Botting, Douglas, Humboldt and the Cosmos, 1973

Brodie, Fawn, The Devil Drives: A Life of Sir Richard Burton, New York, I967

Bruce, James, Travels to Discover the Source of the Nile in the years I768-73, 5 vols, Edinburgh, 1790

Burchell, William, Travels in the Interior of Southern Africa, 2 vols, I822-4, repr. 1953 
Burton, Isabel, Life of Captain Sir Richd. F. Burton, 2 vols, I89 3 Burton, Richard F., First Footsteps in East Africa or, An Exploration of Harar, Memorial Edition, 2 vols, I894

- The Lake Regions of Central Africa, 2 vols, I860, repr. I96I

-Mission to Gelele King of Dahome, Memorial Edition, 2 vols, I89 3

--Mission to Gelele King of Dahome, ed. C.W. Newbury, I966

--Zanzibar: City, Island, and Coast, I872

Cameron, Ian, To the Furthest Ends of the Earth: The History of the

Royal Geographical Society I830-I980, I980

Cameron, Verney, Across Africa, 2 vols, I877

Collis, J.S., Christopher Columbus, I976

Columbus, Christopher, Select Documents Illustrating the Four Voyages

of Columbus, trans. and ed. Cecil Jane, 2 vols, I9 33

Cook, James, Captain Cook's Journal during his First Voyage round the World... I768-7I, ed. W. Wharton, I893

-- The Journals of Captain James Cook, ed. J.C. Beaglehole, 4 vols, Cambridge, I955-74

- A Voyage to the Pacific Ocean ... I776-80, 3 vols, I7 84

Dampier, William, A New Voyage round the World, 2nd edn, I697-I703

Darwin, Charles, The Voyage of the "Beagle", Everyman, I906

Debenham, Frank, Discovery and Exploration, I960

Encyclopaedia of Discovery and Exploration, I8 vols, I97 I

Eyre, Edward J., Journals of Expeditions of Discovery into Central Australia and Overland in the years I840-I, 2 vols, I845

Forster, Georg, A Voyage round the Horld... I772-5, 2 vols, 1777

Forster, John Reinold, Observations made during a Voyage round the

World, 1778 
Hakluyt, Richard, Divers Voyages touching the Discovery of America, ed. J.W. Jones, New York I850, repr. [I97I]

-- The Principall Navigations, I2 vols, Glasgow, I903-5

--_-Wirginian Voyages from Hakluyt, ed. David and Alison Quinn, I973

Hall, Richard, Stanley: An Adventurer Explored, I974

Haresnape, G.L.(ed.), The Great Hunters, Cape Town, 1974

Hibbert, Christopher, Africa Explored: Europeans in the Dark

Continent, I769-I 889 , I982

Humboldt, Alexander von, Aspects of Nature, trans. Mrs Sabine, 2 vols, I849

Jameson, James Sligo, Story of the Rear Column of the Emin Pasha Relief Expedition, I890

Jones, Howard Mumford, O Strange New World: American Culture: The Formative Years, New York, I964

Leichhardt, Ludwig, Journal of an Overland Expedition in Australia I844-5, I847

- - The Letters of F.W. Ludwig Leichhardt, coll. and trans. M. Aurousseau, 3 vols, Cambridge, I968

Lichtenstein, Martin H.K., Travels in Southern Africa in the years I803-6, trans. Anne Plumptre, 2 vols, I8I2-I5

Little, Bryan, Crusoe's Captain: Being the Life of Woodes Rogers, Seaman, Irader, Colonial Governor, I960

Livingstone, David, The Last Journals of David Livingstone, ed. Horace Waller, 2 vols, 1874

---Livingstone's Private Journals, I85I-3, ed. I. Schapera, I960

-Dissionary Travels and Researches in South Africa, I857

McClintock, Sir Leopold, The Voyage of the Fox in Arctic Seas, I859, repr. I908 
Moffat, Robert, The Matabele Journals of Robert Moffat, I829-60, ed. J.P.R. Wallis, I945

Moorehead, Alan, The Blue ivile, I962

-Darwin and the Beagle, I969

-.-Dhe White Nile, I960

Newby, Eric, The World Atlas of Exploration, I975

Park, Mungo, Mungo Park's Travels in Africa, ed. Ronald Miller, I954

Parry, J.H., The Age of Reconnaissance, Berkeley, I98I

- - The Discovery of the Sea, Berkeley, I98I

Polo, Marco, The Book of Ser Marco Polo, trans, and ed. Sir Henry

Yule, 3rd edn, 3 vols, 1903

Purchas, Samuel, Hakluytus Posthumus; or Purchas his Pilgrimes, 20 vols, GIasgow, I905-7

Rae, John, The Melancholy Fate of Sir J. Franklin and his Party, I854

Raisz, Erwin, Mapping the World, I956

Rogers, Woodes, A Cruising Voyage round the Norld... I708-II, I7 I2

Rotberg, Robert, Africa and its Ixplorers, Cambridge, Mass., I970

Russe11, Henry Stuart, The Genesis of queensland, Sydney, I888

Schweinfurth, Georg, The Heart of Africa, trans. Ellen E. Frewer,

2 vols, 1873

Seaver, George, Edward Nilson of the Antarctic, I9 33

Simmons, Jack, Livingstone and Africa, I955

Simpson, Donald, Dark Companions: The African Contribution to the European Exploration of East Africa, I975

Skelton, R.A., Explorers' Maps, I958

Smith, Captain John, Works I608-3I, ed. Edward Arber, 2 vols, I895

Speke, John, Journal of the Discovery of the Source of the Nile,

Edinburgh, I863 
Stanley, Henry Morton, The Exploration Diaries of H.M. Stanley, ed. Richard Stanley and Alan Neame, I96I

- - How I Found Livingstone, 2nd edn, 1872

--In Darkest Africa, I890

--Nhrough the Dark Continent, I878, repr. I907

Symons, A.J.A., H.M. Stanley, I9 33

Thomson, Joseph, Through Masai Land ... I883-4, 4th edn, I885

Thwaites, R.G. (ed.), The Jesuit Relations and Allied Documents: Travels

and Explorations of the Jesuit Missionaries in New France, I6IO-I79I,

73 vols, Cleveland, I896-I90I

Vaillant, François Le, Travels into the Interior Parts of Africa 1780-5,

trans. from the French, 2nd ed, 2 vols, 1796

Wallace, Alfred Russel, The Malay Archipelago, 2 vols, I869

Wilkinson, Clennell, William Dampier, I929

II. Social and Anthropological Background

Arens, W., The Man-Eating Myth: Anthropology and Anthropophagy, New York, I979

Ascherson, Neal, The King Incorporated: Leopold II in the Age of Trusts, 1963

Blyden, Edward W., Christianity, Islam and the Negro Race, I887, repr. Edinburgh, I967

Burrow, John W., Evolution in Society: A Study in Victorian Social Theory, Cambridge, I966

Cairns, H. Alan C., Prelude to Imperialism: British Reactions to Central African Society I840-90, I965 
Cookey, S.J.S., Britain and the Congo question I885-I9I3, I968

Cranstone, B.A.L., The Australian Aborigines, I973

Curtin, Philip D., The Image of Africa: British Ideas and Action, I780-I850, I965

Davidson, Basil, Black Mother: The Years of Trial, I96I

Davies, K.G., The Royal African Company, I957

Davis, David B., The Problem of Slavery in Western Culture, New York, I966

Durand, Gilbert, Les structures anthropologiques de l'imaginaire,

Paris, I969

Earle, Peter, The World of Defoe, I976

Eliade, Mircea, Australian Religions: An Introduction, Ithaca, I973

- - - The Myth of the Eternal Return, trans. Willard R. Trask, Princeton, I954, repr. I965

- - Myths, Dreams and Mysteries: The Encounter between Contemporary

Faiths and Archaic Realities, trans. Philip Mairet, [I960]

Elkin, A.P., Aboriginal Men of High Degree, Sydney, I945

-- The Australian Aborigines: How to Understand Them, 2nd edn, I943

Faber, Richard, The Vision and the Need: Late Victorian Imperialist

Aims, I966

Frazer, Sir James G., The Golden Bough, 3rd edn, I2 vols, I907-I5

Glave, Edward, "Cruelty in the Congo Free State", Century Magazine,

LIV, 5 ( I897), 699-7I5

Hair, P.E.H., The Atlantic Slave Trade and Black Africa, I978

Hallett, Robin, Africa Since I875, Ann Arbor, I974

Africa to I875: A Modern History, Ann Arbor, I970

Harris, Marvin, The Rise of Anthropological Theory, New York, I968

Hiatt, I.R. (ed.), Australian Aboriginal Mythology, Canberra, I975 
Hofstadter, Richard and Lipset, S.M., Turner and the Sociology of the Frontier, New York, I968 Jordan, Winthrop D., White over Black: American Attitudes towards the Negro, I550-I8I2, Chapel Hill, I968

Koebner, Richard and Schmidt, H., Imperialism: The Story and Significance of a Political Word, I840-I960, Cambridge, I964 Lévi-Strauss, Claude, Elementary Structures of Kinship, rev. ed., trans. J.H. Bell and J.R. von Sturmer, ed. R. Needham, I969 The Savage Mind, I966

- Tristres tropiques, trans. John and Doreen Weightman, 1973 Mannix, Daniel P. and Cowley, M., Black Cargoes: A History of the Atlantic Slave Trade, I5I8-I865, I963

Memi, Albert, The Colonizer and the Colonized, New York, I965 Middleton, John (ed.), Myth and Cosmos, New York, I967 Miller, Perry (ed.), The American Puritans, New York, I956 - The New England Mind, 2 vols, Boston I96I, repr. I968-70 Nadel, G.H. and Curtis, P., Imperialism and Colonialism, New York, I964 Neill, Stephen, A History of Christian Missions, Harmondsworth, I964 Northrop, F.S.C. and Livingston, H.H. (eds), Cross-Cultural Understanding: Epistemology in Anthrodology, New York, I964 Porter, Bernard, Critics of Empire: British Radical Attitudes to Colonialism in Africa, I895-I9 I4, I968

Public Record Office, Treasury Records, Royal African Company Archives, T.70

Radcliffe-Brown, A.R., "The Rainbow-Serpent Myth in South-East Australia", Oceania, I (I9 30), 342-7 Reece, R.H.H., Aborigines and Colonists, Sydney, I974 
Spencer, Sir Baldwin, The Arunta, I927

-Wanderings in Wild Australia, 2 vols, 1928

Stevenson, R.I., In the South Seas, I900

Sypher, Wylie, Guinea's Captive Kings: British Anti-Slavery Literature

of the Eighteenth Century, Chapel Hill, I942

Turner, F.J., The Frontier in American History, New York, I920

Williams, Neville, Captains Outrageous: Seven Centuries of Piracy, I96I

III. Philosophical and Psychological Background

Batailles, Georges, Death and Sensuality: A Study of Eroticism and the

Taboo, New York, I962

Copleston, Frederick, Arthur Schopenhauer: Philosopher of Pessimism, I946

Darwin, Charles, The Origin of Species, 1859

Eiseley, Loren, Darwin's Century, I959

Feuerbach, Ludwig, The Essence of Christianity, trans. George Eliot,

New York, I957

Fichte, J.G., The Vocation of Man, trans. William Smith, rev. and ed.

R.M. Chisholm, New York, I956

Foucault, Michel, Madness and Civilization, trans. R. Howard, I96́7

-- The Order of Things, trans. from the French, I970

Freud, Sigmund, Civilization and its Discontents, trans. J.Riviere, I9 39

--Collected Papers, trans. under supervision of J. Riviere, 5 vols,

I9 $24-50$

- The Standard Edition of the Complete Psychological Vorks, trans.

under gen. ed. James Strachey, 24 vols, I953-74

- Totem and Taboo, trans. James Strachey, I950

Gauthier, David P., The Iogic of Leviathan: The Moral and Political

Theory of Thomas Hobbes, Oxford, I969 
Hobbes, Thomas, The English Works, ed. Sir w. Molesworth, II vols, I839-45 Humboldt, Alexander von, Cosmos, [trans. Mrs Sabine, 4 vols, I846-58 Huxley, T.H., "Evolution and Ethics", Collected Essays, 9 vols, I892-5, IX Irvine, William, Apes, Angels and Victorians: A Joint Biography of Darwin and Huxley, I955

Jung, C.G., Psychological Types, trans. H. Godwin Baynes, I923

--Psychology and Alchemy, trans. R.G.C. Hull, I953

Locke, John, An Essay Concerning Human Understanding, ed. A.C. Fraser, 2 vols, Oxford, 1894

Love joy, A.0., Essays in the History of Ideas, Baltimore, I948

--The Great Chain of Being, I9 33, reprint. Cambridge, Mass., I942

--Cand Boas, G., Primitivism and Related Ideas in Antiquity, New York, 1965

Nietzsche, Friedrich, Beyond Good and Evil, trans. R.J. Hollingdale, Harmondsworth, I97 3

--- Ecce Homo, trans. A.M. Iudovici, I9 II

--- The Gay Science, trans. Walter Kaufmann, New York, I974

-Dhilosophy and Truth: Selections from Nietzsche's Notebooks of

the Early Seventies, trans. and ed. D. Breazeale, Brighton, I979

- Twilight of the Idols and The Anti-Christ, trans. R.J. Hollingdale, Harmondsworth, I968

Petty, Sir William, The Economic Writings, ed. C.H. Hull, 2 vols, Cambridge, 1899

Rousseau, Jeen Jacques, The Miscellaneous Works, 5 vols, 1767 Rycroft, Charles, A Critical Dictionary of Psychoanalysis, I968

Schopenhauer, Arthur, The World aB Will and Idea, trans. R.B. Haldane and J. Kemp, 4 th edn, 3 vols, I896

Seward, A.C. (ed.), Darwin and Modern Science, Cambridge, I909 
Stephen, Leslie, Social Rights and Duties, 2 vols, I896

Weil, Simone, The Notebooks of Simone Heil, trans. A.Kills, 2 vols, I956

-_- Oppression and Liberty, trans. A. Wills and J. Petrie, 1958

Wells, H.G., "Human Evolution, an Artificial Process", Fortnightly Review, IXVI ( I898), 590-5

Wittels, Fritz, Sigmund Freud, his Personality, his Teaching and his School, trans. E. and C. Paul, New York, I9 24

IV. Critical Works

Adams, Percy G., Travel Iiterature and the Evolution of the Novel, Lexington, $\mathrm{Ky}$, 1983

Anderson, Don, "A Severed Leg: Anthropophagy and Communion in Patrick White's Fiction", Southerly, 40 (I980), 399-4I7

Argyle, Barry, Patrick White, 1967

Atkinson, Geoffroy, The Extraordinary Voyage in French Literature before I700, New York, I920

- The Extraordinary Voyage ... from I700 to I720, Paris, I9 22

Auerbach, Erich, Mimesis: The Representation of Reality in Westerm

Literature, trans. willard R. Trask, New York, I957

Beatson, Peter, "The Three Stages: Mysticism in Patrick white's Voss", Southerly, 30 (I970), III-2I

Beer, Gillian, Darwin's Plots: Evolutionary Narrative in Darwin, George Eliot and Nineteenth-Century Fiction, 1983

Bell, Michael, Primitivism, I972

Berthoud, Jacques, Joseph Conrad: The Major Phase, Cambridge, I978

Bradbrook, M.C., Joseph Conrad: Poland's English Genius, Cambridge, I942

--- Iiterature in Action: Studies in Continental and Commonweal th

Society, I972 
Brissenden, R.F., Patrick White, rev. ed., I969

Butler, Marilyn, Romantics, Rebels and Reactionaries: English Literature and its Background, I760-I830, Oxford, I98I

Carnochan, H.B., Confinement and Flight, Berkeley, 1977

Cawley, R.R., The Voyagers and Elizabethan Drama, Boston, I9 38

Chase, Richard, Herman Melville: A Critical Study, New York, I949

-.-(ed.), Melville: A Collection of Critical Essays, Englewood Cliffs, N.J., I962

Conrad, Peter, Imagining America, I980

Darras, Jacques, Joseph Conrad and the West: Signs of Empire, trans.

A. Luyat and J. Darras, I982

Dryden, Edgar A., Melville's Thematics of Form, Baltimore, I968

Dudley, Edward and Novak, Maximillian E. (eds), The Wild Man Within,

Pittsburgh, I972

Dutton, Geoffrey (ed.), The Literature of Australia, Harmondsworth, I964 --Datrick White, 4th ed., Melbourne, I97 I

Fairchild, Hoxie Neal, The Noble Savage: A Study in Romantic Naturalism,

New York, I9 28

FitzGerald, Margaret M., First Follow Nature: Primitivism in English

Poetry, I725-50, New York, I976

Furst, Lilian R., The Contours of European Romanticism, I979

--Romanticism in Perspective, New York, 1969

Fussell, Paul, Abroad: British Literary Traveling Between the Wars,

New York, I9 80

Green, Martin, Dreams of Adventure, Deeds of Empire, New York, I979

Guerard, Albert J., Conrad: The Novelist, Cambridge, Mass., I958, I979

Hardy, Barbara, The Appropriate Form: An Essay on the Novel, I97I 
Heller, Erich, The Disinherited Mind: Essays in Modern German

Literature and Thought, Cambridge, I952

Henkin, Leo J., Darwinism in the English Novel, New York 1940, 1963

Howard, Leon, Herman Melville: A Biography, Berkeley, I95I

Hunter, Allan, Joseph Conrad and the Ethios of Darwinism, Beckenham, I983

Johnson, Bruce, Conrad's Models of Mind, Minneapolis, I97 I

Johnson, Manly, "A Fringe of Leaves: White's Genethlicon", Texas

Studies in Language and Literature, 2I ( I979), 226-39

Jones, Howard Mumford, The Frontier in American Fiction, I956

Karl, Frederick R. (ed.), Joseph Conrad: A Collection of Criticism,

New York, I975

Kermode, Frank, "Introduction" to The Tempest, Arden Shakespeare,

6 th ed., I958

Kiernan, Brian, Patrick White, I980

Levin, Harry, The Myth of the Golden Age in the Renaissance, New York, I969

Lewis, R.W.B., The American Adam: Innocence, Tragedy and Tradition in

the Nineteenth Century, Chicago, I955, I97 I

Leyda, Jay, The Melville Log: A Documentary Life of Herman Melville, I8I9-9I, 2 vols, New York, I969

Lockhardt, Donald, "The Fourth Son of the Mighty Emperor's The Ethiopian

Background of Johnson's Rasselas", PMIA, LXXVIII (I983), 5I6-28

Lowes, J.I., The Road to Xanadu, Sentry Edition, Boston, I955

Mahood, Molly M., The Colonial Encounter: A Reading of Six Novels, I977

Mannoni, Otave, Prospero and Caliban: The Psychology of Colonization,

trans. P. Powesland, New York, I956

Miller, J. Hillis, The Disappearance of God: Five Nineteenth Century

Writers, Cambridge, Mass., I975

Monk, Samuel H., The Sublime: A Study of Critical Theories in 
Eighteenth-Century England, Ann Arbor, I9 35, I960

Moore, John R., Daniel Defoe: Citizen of the Modern World, Chicago, I958

Morley, Patricia A., The Mystery of Unity: Theme and Technique in the

Novels of Patrick White, Montreal, 1972

Mudrick, Marvin (ed.), Conrad: A Collection of Critical Essays,

Englewood Cliffs, N.J., I966

Novak, Maximillian E., Defoe and the Nature of Man, Oxford, 1963

Olson, Charles, Call Me Ishmael, San Francisco, I947

Parker, H. and Hayford, H. (eds), Moby Dick as Doubloon, New York, I97O

Richetti, John J., Defoe's Narratives, Oxford, I975

Ridley, Hugh, Images of Imperial Rule, I9 33

Rogers, Pat, The Augustan Vision, I974

---(ed.), Defoe: The Critical Heritage, I972

---Robinson Crusoe, I979

Roussel, Royal, The Metaphysics of Darkness: A Study in the Unity and

Development of Conrad's Fiction, Baltimore, I97I

Said, Edward i., Orientalism, 1978

Sandison, Alan, the Wheel of Empire, 1967

Scrimgeour, Gary J., "The Problem of Realism in Defoe's Captain

Singleton", Funtingdon Library Quarterly, XXVII (I963), 2I-38

Secord, A.W., Studies in the Narrative Method of Defoe, Urbana, I9 24

Shepherd, R. and Singh, K. (eds), Patrick White: A Critical Symposium, Adelaide, 1978

Sherry, Norman, Conrad's Eastern World, Cambridge, I966

-Conrad's Western World, Cambridge, I97 I

--(ed.), Conrad: The Critical Heritage, I973

---(ed.), Joseph Conrad: A Commemoration, I976

Smith, M. van Wyk, "The Origins of Some Victorian Images of Africa", 
English in Africa, VI, I (I979), I2-32

Spears, Monroe K., Dionysus and the City: Modernism in Twentieth-

Century Poetry, New York, I970

Starr, George A., Defoe and Spiritual Autobiography, Princeton, I965

Street, Brian V., The Savage in Literature: Representatives of

'Primitive' Society in English Fiction, I858-I920, 1975

Sutherland, James R., Daniel Defoe: A Critical Study, Cambridge, Mass, I954

Tanner, Tony, City of Words: American Fiction I950-70, I97 I

Thompson, Lawrance, Melville's Quarrel with God, Princeton, I952

Trilling, Lionel, Beyond Culture: Essays on Literature and Learning, I966

Turner, James G., The Politics of Landscape: Rural Scenery and Society

in English Poetry, I6 30-60, Oxford, I979

Walsh, Nilliam, Patrick White's Fiction, Sydney, I977

Warren, Robert Penn, Selected Essays, I964

Watt, Ian, Conrad in the Nineteenth Century, I980

--Dhe Rise of the Novel, I957

Watts, Cedric, A Preface to Conrad, New Yoric, I982

Way, Brian, Herman Melville: Moby Dick, I978

Wilkes, G.A., "A Reading of Patrick White's Voss", Southerly, 27 ( I967),

$159-73$

-Dhe Stockyard and the Croquet Lawn: Iiterary Evidence for

Australian Cultural Development, I9 81

Williams, Ioan, The Novel and Romance, I970

Williams, Raymond, The Country and the City, I973

Zweig, Paul, The Adventurer, 1974 
V. Literary Texts

Ballantyne, R.M., Coral Island, Everyman, I907

Brink, André, An Instant in the Wind, I976

Buchan, John, Prester John, I9IO

Bunyan, John, The Pilgrim's Progress, ed. James Wharey, Oxford, I9 28

Camoens, Luis Vaz De, The Lusiads, trans. and ed. C. Atkinson, Harmondsworth, I952

Coetzee, John M., Dusklands, Johannesburg, I974

Coleridge, Samuel Taylor, Biographia Literaria, ed. George Watson, I965

-Coleridge: Poems, ed. John Beer, I974

Conrad, Joseph, Joseph Conrad: Letters to William Blackwood and David

S. Meldrum, ed. W. Blackburn, Durham, N.C., I958

- - Joseph Conrad's Letters to R.B. Cunninghame Graham, ed. C.T.

Watts, Cambridge, 1969

---Joseph Conrad: Life and Letters, ed. G. Jean-Aubry, 2 vols, I927

- - The Works of Joseph Conrad, Uniform Edition, 22 vols, I923-8

Cooper, Jamea Fenimore, The Prairie, San Francisco, I950

Defoe, Daniel, Atlas Maritimus et Commercialis, 1728

- An Essay upon Projects, 1702

- An Essay upon the Trade to Africa, I7 II

- A General History of Discoveries and Improvements, $1726-7$

- General History... of the Pyrates, I724

- Jure Divino, 1706

- The Life, Adventures and Piracies of the Famous Captain Singleton,

ed. James Sutherland, Everyman, 1963

- The Life and Strange Surprising Adventures of Robinson Crusoe of

York, Mariner, ed. J. Donald Crowley, Oxford English Novels, I972

---Mere Nature Delineated, I726 
A New Voyage around the World, 2 vols, 1725

--Political History of the Devil, I726

- The Reformation of Mannerg, 1702

- - A Review, 9 vols, I704-I3

Doyle, Arthur Conan, The Lost iforld, I9 I2

Faulkner, William, The Bear, collected in Go Down Moses, Harmondsworth, I960

Forster, E.M., A Passage to India, Harmondsworth, 1957

Garnett, Edward, Letters from Conrad, I895-I924, I9 28

Golding, William, Lord of the Flies, I9 54

Haggard, H. Rider, King Solomon's Mines, I886

Hemingway, Ernest, "Big Two-Hearted River" in The Short Stories of

Emest Hemingway, New York, I9 38

Hope, A.D., Collected Poems, I930-65, Sydney, I965

Johnson, Samuel, Rasselas, ed. Geoffrey Tillotson and Brian Jenkins, Oxford, I977

Kipling, Rudyard, Life's Handicap, I896

Lawrence, D.H., Kangaroo, I923

- - Letters of D.H. Lawrence, ed. J.T. Boulton et al., 7 vols, Cambridge, I979-

- - Phoenix II, ed. Warren Roberts and Harry T. Moore, I968

----Psychoanalysis and the Unconscious, Adelphi Library, I9 3 I

- The Rainbow, I9I5, repr. I923

Lewis, Janet, The Invasion, Chicago, I9 32, repr. I960

Malouf, David, An Imaginary Life, I978

Mandeville's Trevels, ed. M.C. Seymour, Oxford, I967

Maugham, $w$. Somerset, The Explorer, Collected Edition, 1967

Melville, Herman, The Complete Stories of Herman Melville, ed. Jay Leyda, New York, I949 
- Hawthorne and his Mosses", collected in Hawthorne: The Critical Heritage, ed. J. Donald Crowley, I970

-.- The Letters of Herman Melville, ed. M.R. Davis and W.H. Gilman, INew Haven, I960

---Moby-Dick, ed. Charles Feidelson, Jr., Indianapolis, I964

- - Typee, ed. George Woodcock, Harmondsworth, I972

Montaigne, Michel, The Essayes of Montaigne, trans. John Florio, I89 I

Rousseau, Jean Jacques, Confessions, trans. J.M. Cohen, Harmondsworth, I953

Sterne, Lawrence, A Sentimental Journey through France and Italy, in

Works of Sterne, 2 vols, New York, I900

Swift, Jonathan, Gulliver's Travels, ed. Peter Dixon and John Chalker, Harmondsworth, I967

Verne, Jules, A Journey to the Center of the Earth, I864

Nebster, J. Provand, The Oracle of Baal, I396

Wells, H.G., The Island of Dr Moreau, I896

White, Patrick, The Eye of the Storm, 1973

- Flaws in the Glass, I98I

---A Fringe of Leaves, 1976

---Voss, I957, I980

Woolf, Virginia, To the Lighthouse, I927, I977

Hordsworth, William, The Prelude, ed. Ernest de Selincourt, rev.

Helen Darbishire, Oxford, I959 
Albert, Captain, 24

Alexander, Michael, 309n, 3IOn, 3IIn

Anderson, Don, 3IIn

Arens, W., 3IOn

Ascherson, Neal, 298n, 30In, 303n

Atlas Geographus, $78,28 \mathrm{In}$

Atlas Maritimus, see Defoe

Avery, Captain, 72, 77

Baker, Sir Samuel, 204

Ballantyne, R.M., I22

Coral Island, I66-8, I69-7I, 294n

Barlowe, Arthur, I0, $273 \mathrm{n}$

Barth, Heinrich, I96, $298 \mathrm{n}$

Barttelot, E.M., I96, 298n

Bataille, Georges, I85, 296n

Baxter, John (Eyre expedition),

$305 n$

Baxter, John (second mate of

Stirling Castle, shipwrecked), 3IOn

Beatson, Peter, 308n

Beckett, Samuel,

47

Beer, Gillian, 304n

Bennett, Josephine, $272 n$

Berthoud, Jacques, $303 n$

Bible, 2

Acts, $289 n$

Exodus, II, 55, 58

Genesis, 2, 4, 9, II, 23, 34-5,

I98, 249, 274n

Isaiah, 3, I9, 91

Job, 29 In

Psalms, $278 \mathrm{n}$

I Samuel, 23, 274n
Blake, William, 73, 288n

Blyden, Edward W., 276n

Boswell, James, $287 \mathrm{n}$

Botting, Douglas, $290 \mathrm{n}$

Bougainville, Louis Antoine de, 33

Bracefell (Bracefield), James,

$269,309 n, 3 I I n$

Brady, Veronica, $309 n$

Breughel, Pieter (the elder), II8

Brink, André, An Instant in the

Wind, 269

Brissenden, R.F., 225, 305n

Brodie, Fawn, 300n

Browne, Sir Thomas, I3I, 2 I4

Browning, Robert, 142,29 In

Bruce, James, I06, $287 \mathrm{n}$

Buchan, John, Prester John, I99

Bunyan, John, Pilgrim's Progress,

$58,62-3,279 n$

Burchell, William, 28-9, 275n

Burke, Robert, $305 n$

Burton, Richard, I96, I97, I98, $200-I, 202-3,212,220,298 \mathrm{n}$,

$299 \mathrm{n}, 300 \mathrm{n}, 302 \mathrm{n}$

Cairns, H. Alan, 299n

Cameron, Ian, I29-30, 289n

Cameron, Verney, 70, 204, 30In

Camoens, Luiz Vaz De, II8, 288n

Carlyle, Thomas, 289n, 290n

Carnochan, W.B., 5I, $278 \mathrm{n}$

Casement, Roger, 207, 30In

Cawley, R.R., $274 \mathrm{n}$

Century Magazine, 208 
Coetzee, J.M., Dusklands, 269, 3 IIn

Coleridge, Samuel Taylor, 5, I09, I42-3, 272n, 287n, 29 In

Ancient Mariner, I44-8, I54, 29 In Collis, J.S., $272 \mathrm{n}$

Columbus, Christopher, I-4, 6-IO, I6, I7, 24, I30, I6I, 272n, 294n Congo Reform Society, 207, 30In Conrad, Joseph,

Almayer's Folly, I58, I6I, I69, $293 n, 294 n, 295 n, 299 n$

"Autocracy and War", 2II, 302n

Congo Diary, I96, 206

End of the Tether, 187

Falk, I56-7, I92, $293 \mathrm{n}$

"Geography and Some Explorers", I95, I96, 297n, $298 \mathrm{n}$

Heart of Darkness, 45, 74, I87-223, 297-304n

Letters (to Cunninghame Graham), I57-8, I59, I65, I89, 2I8, 293n, $294 \mathrm{n}, 297 \mathrm{n}, 303 \mathrm{n}$; (to William Blackwood), $293 n$

Lord Jim, $294 \mathrm{n}$

Outcast of the Islands, I56-86, $293-6 n$

"Outpost of Progress", I4, 274n

Personal Record, I57, $293 \mathrm{n}$ "Travel", $303 n$

Under Western Eyes, I77-8, 295n Youth, I87, I89-90, I9 I, I9 3, $297 n, 298 n$

Cook, Captain James, 33, 97, 276n, $285 n$

Cookey, S.J.S., 30In, 302n, 303n
Cooper, James Fenimore, The

Prairie, II5, 288n

Cranstone, B.A.I., 3IIn

Crowley, J. Donald, 27 \&n, $290 n$

Curle, Richard, 296n

Curtin, Philip D., I96-7, 299n, $302 n$

Darwin, Charles, 22, 3I, 32, $33-4,37,96, I 22, I 54, I 55, I 85$, $22 \mathrm{I}, 276 \mathrm{n}, 288 \mathrm{n}, 29 \mathrm{I}-2 \mathrm{n}, 304 \mathrm{n}$ Davies, K.G., 86, 283n Davis, David B., $275 n$ Davis, M.R. and Gilman, W.H., 290 n Defoe, Daniel, IOI, 27 I, 285n Atlas Maritimus, $78,85-6,89$, $90,28 I n, 282 n, 283 n$ Captain Singleton, 70-94,97, $28 I-4 n$

Essay upon Projects, 94, 284n

Essay upon the Trade to Africa, $284 \mathrm{n}$

General History of Discoveries, $66,92,280 n, 283 n, 284 n$

Jure Divino, $77,28 I n$

Mere Nature Delineated, 284n

Moll Flanders, 73

New Voyage Around the World, 90-I, 282n, 283n

Political Hiatory of the Devil, $282 n$

Reformation of Manners, 93, 284n Review, 8I, 282n, 284n Robinson Crusoe, 45-69, 79, 93-4, $95,97,98,100,146$, I66, $278-80 n, 282 n, 285 n$ 
Del commune, Alexandre, I95

Dickens, Charles, 2I6, 303n

Diderot, Denis, II2

Dilke, Sir Charles Wentworth, 207

Doyle, Sir Arthur Conan, The

Lost World, 220

Drayton, Michael, I7-I8, 274n

Dryden, Edgar A., 285n

Dryden, John, 20I, 300n

Dudley, Edward and Novak,

Maximillian, 283n, 288n

Earle, Peter, 9I, 282n, 283n, 284n

Eiseley, Loren, 276n

Eliade, Mircea, 249, 308n

Eliot, George, 65, 231

Eliot, T.S., 222, 304n

Elkin, A.P., 307-8n

Emerson, Ralph Waldo, 5, 36, 276n

Eyre, Edward, 305n

Fairchild, Hoxie Neal, 276n

Faulkner, William, The Bear, 27 I, $3 I 2 \mathrm{n}$

Feidelson, Charles Jr., 289n

Feuerbach, Ludwig, 43-4, 277n

Fichte, J.G., I36, 234, 246, 290n, $306 n$

Forster, E.M., A Passage to India, $220,303 n$

Franklin, Sir John, I92, $298 \mathrm{n}$

Fraser, Eliza, 250, 269, 305n,

$$
309 n \text {, 3IIn }
$$

Frazer, Sir James, $274 \mathrm{n}$
Freeman, John, 7I, 86, 87-9,

$94,283 n$

Freud, Sigmund, 38, I84, I85,

22I, 296n, 304n

Furst, Lilian R., 290n

Galsworthy, John, 297 n

Garnett, Edward, I69, I89, 297n

Gilbert, John, 305n

Gilman, W.H. see Davis, M.R. and

Gilman, W.H.

Glave, Edward, 208, 30In, 302n

Goethe, J.W. von, I $36,290 \mathrm{n}$

Golding, William, Lord of the

Flies, 74, I66, 269

Guerard, Albert, 290n, 296n

Guizot, Francois, I95

Haggard, Sir H. Rider, King

Solomon's Mines, I99

Haie, Edward, IO

Hakluyt, Richard, I2, I5, I7, I8, $62,7 \mathrm{I}, 273 \mathrm{n}, 274 \mathrm{n}, 275 \mathrm{n}, 279 \mathrm{n}$, 28 In

Hardie, Keir, 218, $303 \mathrm{n}$

Hardy, Barbara, I66, 294n

Hardy, Thomas, I27, I83, $296 \mathrm{n}$

Harris, Frank, 203, 300n

Haw thorne, Nathaniel, I35, I54

Hay, Edward see Haie, Edward

Hayford, H. see Parker, H. and

Hayford, $H$.

Hegel, G.W.F., I35

Henkin, Leo J., 299n 
Herodotus, 27, 275n

Herzog, Werner, 74

Hiatt, L.R., 307n

Hibbert, Christopher, 300n

Hobbes, Thomas, $77-9,80,81,82$, 83,84 , IIO-II, $28 \mathrm{In}, 282 \mathrm{n}$

Hodges, William, $276 \mathrm{n}$

Howard, Leon, 285n, 289n

Humboldt, Alexander von, 3I-2, 33,

I30-I, I96, 275n, 276n, 289 n, 290n

Huxley, T.H., 2I8, $303 \mathrm{n}$

Hymns Ancient and Modern, $294 \mathrm{n}$

Ibsen, Henrik, I42, 29 In

James, Henry, I97, 23 I

The Beast in the Jungle, 222

Jane, Cecil, $272 \mathrm{n}$

Jesuit Relations, III

Johnson, Bruce, I75, 293 n, 294-5n

Johnson, Manly, 3IOn

Johnson, Samuel, 287 n

Rasselas, 95, I02-3, I06-I0,

$I 42,286 \mathrm{n}$

Jones, J.H., $275 n$

Joyce, James, 222, 244, 304n, 307n

Jung, C.G., 22I, 256, 304n, 306n,

$309 n$

Keats, John, I36, 290 n

Kelly, Ned, 224

Kiernan, Brian, 225, 306n

Kipling, Rudyard, I76-7, 295n

Kotzebue, Otto von, I22
Lawrence, D.H., 46, I28, 22I, $222-3,245,25 \mathrm{I}, 289 \mathrm{n}, 304 \mathrm{n}$, $307 n, 309 n$

Kangaroo, 25I-2, 277n, 309n

Leichhardt, Ludwig, 37, 224, $276 \mathrm{n}, 305 \mathrm{n}$

Leopold II, King of the Belgians, $204,205,207,208,218,30$ In

Le Vaillant, Francois, 29-3I,

$34,36,275 n$

Levin, Harry, 288n

Lewis, Janet, The Invasion,

26I, 3IOn

Leyda, Jay, 286n, 29 In, 292n

Little, Bryan, 279n

Livingstone, David, I98, 203, $204,205,206,275 n, 296 n, 298 n$,

$299 \mathrm{n}, 30 \mathrm{In}$, 3IOn

Lobo, Jerome, I06

Locke, John, 64, 280n

Lockhart, Donald, 286n

Lowes, J.L., 29 In

Lyell, Sir Charles, 32

Lyte, H.F., $294 n$

Mallock, William, The Veil of the Temple, $276 \mathrm{n}$

Malouf, David, An Imaginary Life, 269

Malthus, Thomas Robert, 23, 221

Mandeville's Travels, 2, 27, 272n, 275n

Marvell, Andrew, 54, $278 \mathrm{n}$

Marx, Karl, 22I, 304n

Maugham, W. Somerset, The

Explorer, 220, 303n 


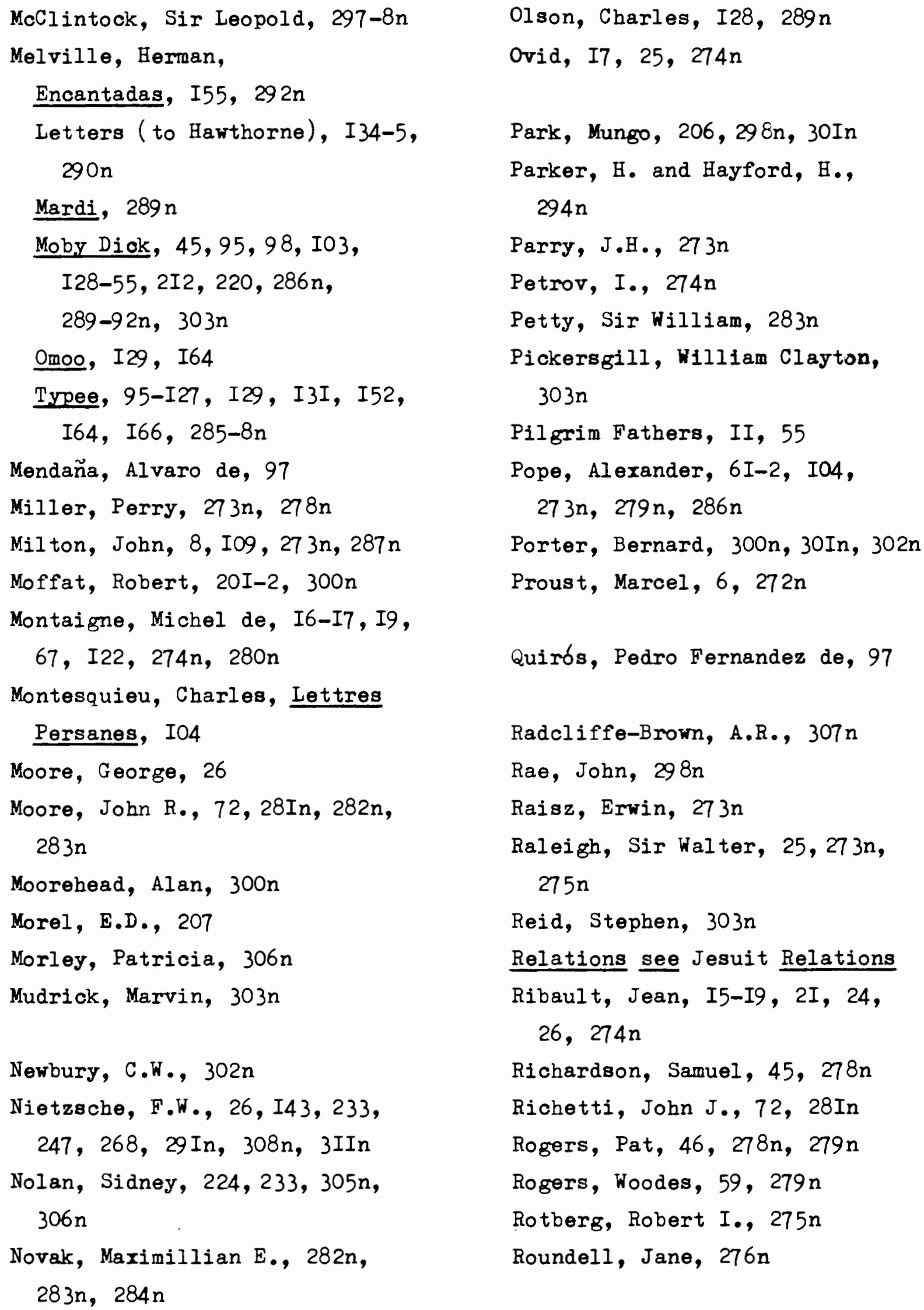


Rousseau, Jean-Jacques, 30, 95 , I02, I09-I2, II4, II6, I25-6, $287 \mathrm{n}, 288 \mathrm{n}$

Roussel, Royal, I7 3-4, 29 3n, 294n Royal African Company, 7I, 86, 87 , $88,94,283 n$

Russell, Henry Stuart, $309 n$

Rycroft, Charles, 38, 277n, 290n

Said, Edward, 3IOn

Sandison, Alan, I35-6, 290 n, 29 In

Schiller, J.C.F. von, I30-I

Schopenhauer, Arthur, I74-5, I88-9, I90, 2I0-II, 2I3, 2I4, $294 n, 295 n, 297 n, 302 n, 303 n$

Schreiner, Olive, I42, 29 In

Schweinfurth, Georg, I96, I97-8, 202 , 298n, 299n, 300n

Scott, Paul, I77, 295n

Scrimgeour, Gary J., 7I, 28In, $282 n$

Seaver, George, $275 \mathrm{n}$

Secord, A.H., $279 \mathrm{n}$

Selkirk, Alexander, 59-60

Seward, A.C., $274 n$

Seymour, M.C., $272 \mathrm{n}$

Shakespeare, William, 32, 57, I92, $278 n$

The Tempest, I2-I4, I9, $273 \mathrm{n}$, $274 n$

Shepherd, R. and Singh, K., $309 n$ Sherry, Norman, 206, $293 \mathrm{n}, 294 \mathrm{n}$, $296 n, 298 n, 30 I n$

Simmons, Jack, 30In
Singh, K. see Shepherd, R. and Singh, $K$. Smith, Captain John, $273 n$ Société Anonyme Belge, I95 Society for the Suppression of Slavery, 205 Speke, John, 203, 298n, 300n, 30In Spencer, Sir Baldwin, 3IOn Stanley, H.M., I5, I9-24, 25-6, I94, I96, I97, I98, 203, 204, $206,220,274 n, 275 n, 298 n, 299 n$, 300-In

Starr, George, 57, 279n

Steele, Richard, 60, 279n

Stephen, Sir Leslie, 29 In

Sterne, Lawrence, A Sentimental

Journey, I05, 286n

Strachey, Lytton, I3I, $290 \mathrm{n}$

Strindberg, August, 304n

Sultan of Zanzibar, 1876 treaty

with, 204

Sutherland, James, 28In

Swift, Jonathan, 7I, 28In, 283n, $285 \mathrm{n}$

Gulliver's Travels, I04-5, 286n

Swinburne, Algernon Charles, 203, $300 \mathrm{n}$

Symcox, Geoffrey, 288n

Symons, Arthur, 203, 300n

Thomas, N.W., 3IOn, 3IIn

Thompson, Lawrance, $289 \mathrm{n}, 29$ In

Van Wyk Smith, M., 78, 28In 
Verne, Jules, Journey to the

Center of the Earth, I99-200

Wallace, Alfred Russel, I80-2, I86, 295n, 296n

Wallis, Samuel, 33

Warren, Robert Penn, I47, 29 In

Watt, Ian, I57, 200, 215, 278n,

$293 n, 298 n, 299 n, 303 n$

Watts, C.T., $297 \mathrm{n}$

Webster, J.P., The Oracle of

Baal, I99

Weil, Simone, 254, 27 I, 309n, 3IIn

Wellek, René, 290 n

White, Patrick, 220

Eye of the Storm, 250, 309n

Flaws in the Glass, $305 \mathrm{n}, 306 \mathrm{n}$

Fringe of Leaves, 250-7 I, 305n, 309-I2n

Vivisector, 224

Voss, $45,46,224-49,250,255$, $262,266,305-8 \mathrm{n}, 309 \mathrm{n}$, 3IIn

Wilde, Oscar, 2I9, 265, 3IIn

Wilkes, G.A., $308 \mathrm{n}$

Williams, Ioan, $284 \mathrm{n}$

Williams, Tennessee, 23 I

Wilson, Edward, 28, 275n

Wittels, Fritz, 304n

Woodcock, George, 285n

Woolf, Virginia, To the Lighthouse,

I43, 222, 304n, 306n
Wordsworth, William, The

Prelude, $39-43,277 \mathrm{n}$

Zweig, Paul, 240, 306n 